\title{
Immunomodulators and immunosuppressants for multiple sclerosis: a network meta-analysis (Review)
}

Filippini G, Del Giovane C, Vacchi L, D’Amico R, Di Pietrantonj C, Beecher D, Salanti G

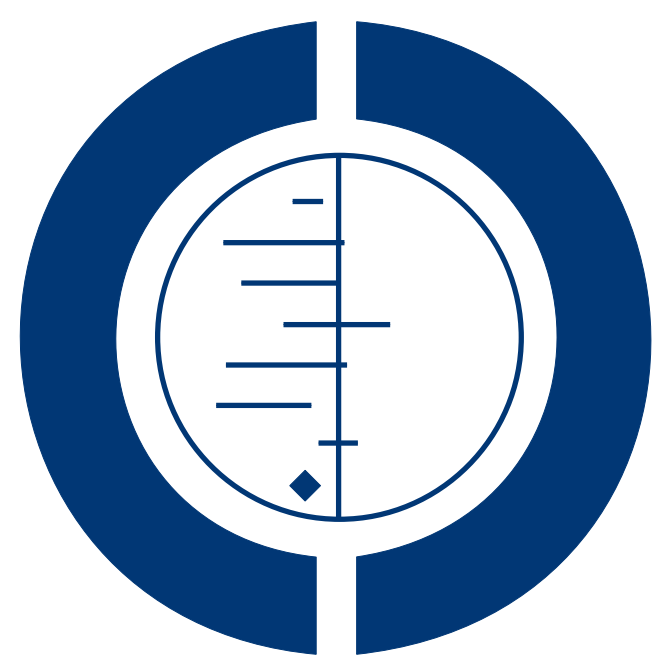

\section{THE COCHRANE COLLABORATION $^{\circledR}$}

This is a reprint of a Cochrane review, prepared and maintained by The Cochrane Collaboration and published in The Cochrane Library 2013, Issue 6

http://www.thecochranelibrary.com

\section{WILEY}

Immunomodulators and immunosuppressants for multiple sclerosis: a network meta-analysis (Review)

Copyright $\odot 2013$ The Cochrane Collaboration. Published by John Wiley \& Sons, Ltd. 
TABLE OF CONTENTS

HEADER . . . . . . . . . . . . . . . . . . . . . . . . . . . . . . . . . . . . . . . . . . . . .

ABSTRACT . . . . . . . . . . . . . . . . . . . . . . . . . . . . . . . . . . . . . . . . . . . . . .

PLAIN LANGUAGE SUMMARY . . . . . . . . . . . . . . . . . . . . . . . . . . . . . . . . . . . . . . . . . . . . . .

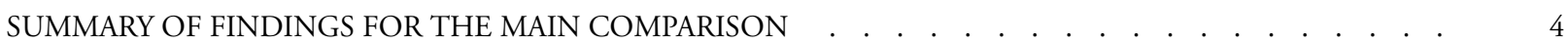

BACKGROUND . . . . . . . . . . . . . . . . . . . . . . . . . . . . . . . . . . . . . . . . . . . . 16

OBJECTIVES . . . . . . . . . . . . . . . . . . . . . . . . . . . . . . . . . . . . . . . . . . . .

METHODS . . . . . . . . . . . . . . . . . . . . . . . . . . . . . . . . . . . . . . . .

RESULTS . . . . . . . . . . . . . . . . . . . . . . . . . . . . . . . . . . . . . . . . . . .

Figure 1. . . . . . . . . . . . . . . . . . . . . . . . . . . . . . . . . . . . . . 21

Figure 2. . . . . . . . . . . . . . . . . . . . . . . . . . . . . . . . . . . . . . . . .

Figure 3. . . . . . . . . . . . . . . . . . . . . . . . . . . . . . . . . . . . . 23

Figure $4 . \quad$. . . . . . . . . . . . . . . . . . . . . . . . . . . . . . . . . . . . . . . $\quad 27$

Figure 5. . . . . . . . . . . . . . . . . . . . . . . . . . . . . . . . . . . . . 28

Figure 6. . . . . . . . . . . . . . . . . . . . . . . . . . . . . . . . . . . . . . .

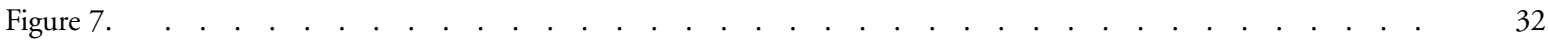

DISCUSSION . . . . . . . . . . . . . . . . . . . . . . . . . . . . . . . . . . . . . . . . .

AUTHORS' CONCLUSIONS . . . . . . . . . . . . . . . . . . . . . . . . . . . . . . . . . . . . . . .

ACKNOWLEDGEMENTS . . . . . . . . . . . . . . . . . . . . . . . . . . . . . . . . . . . . . . .

REFERENCES . . . . . . . . . . . . . . . . . . . . . . . . . . . . . . . . . . . . . . . . 36

CHARACTERISTICS OF STUDIES . . . . . . . . . . . . . . . . . . . . . . . . . . . . . . . . . . . 44

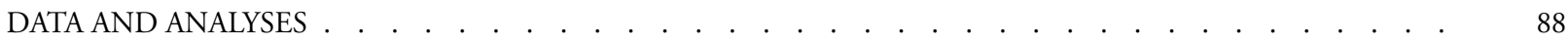

Analysis 1.1. Comparison 1 Comparisons for relapse over 12 months, Outcome 1 Relapse over 12 months in MS of all types. . . . . . . . . . . . . . . . . . . . . . . . . . . . . . . . . . . . . . . . 94

Analysis 1.2. Comparison 1 Comparisons for relapse over 12 months, Outcome 2 Relapse over 12 months in relapsingremitting MS.

Analysis 1.3. Comparison 1 Comparisons for relapse over 12 months, Outcome 3 Relapse over 12 months in progressive MS.

Analysis 2.1. Comparison 2 Comparisons for relapse over 24 months, Outcome 1 Relapse over 24 months in MS of all types. .

Analysis 2.2. Comparison 2 Comparisons for relapse over 24 months, Outcome 2 Relapse over 24 months in relapsingremitting MS.

Analysis 2.3. Comparison 2 Comparisons for relapse over 24 months, Outcome 3 Relapse over 24 months in progressive MS.

Analysis 3.1. Comparison 3 Comparisons for relapse over 36 months, Outcome 1 Relapse over 36 months in MS of all

Analysis 4.1. Comparison 4 Comparisons for disability progression over 24 months, Outcome 1 Disability progression over 24 months in MS of all types.

Analysis 4.2. Comparison 4 Comparisons for disability progression over 24 months, Outcome 2 Disability progression over 24 months in relapse-remitting MS

Analysis 4.3. Comparison 4 Comparisons for disability progression over 24 months, Outcome 3 Disability progression over 24 months in progressive MS.

Analysis 5.1. Comparison 5 Comparisons for disability progression over 36 months, Outcome 1 Disability progression over 36 months in progressive MS. . . . . . . . . . . . . . . . . . . . . . . . . . . . . 117

Analysis 6.1. Comparison 6 Comparison for adverse events, Outcome 1 Serious adverse events. . . . . . . . . . . 118

Analysis 6.2. Comparison 6 Comparison for adverse events, Outcome 2 Withdrawals due to adverse events. $\quad . \quad$. $\quad . \quad 120$

ADDITIONAL TABLES . . . . . . . . . . . . . . . . . . . . . . . . . . . . . . . . . . . . . . . 121

APPENDICES . . . . . . . . . . . . . . . . . . . . . . . . . . . . . . . . . . . . . 131

HISTORY . . . . . . . . . . . . . . . . . . . . . . . . . . . . . . . . . . . . . . . . . 133

CONTRIBUTIONS OF AUTHORS . . . . . . . . . . . . . . . . . . . . . . . . . . . . . . . . . . . . . . 133

DECLARATIONS OF INTEREST . . . . . . . . . . . . . . . . . . . . . . . . . . . . . . . . . . . . . . . . . . 134

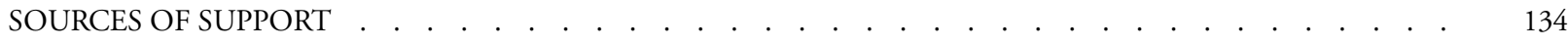

Immunomodulators and immunosuppressants for multiple sclerosis: a network meta-analysis (Review)

Copyright $\odot 2013$ The Cochrane Collaboration. Published by John Wiley \& Sons, Ltd. 
DIFFERENCES BETWEEN PROTOCOL AND REVIEW

Copyright $\odot 2013$ The Cochrane Collaboration. Published by John Wiley \& Sons, Ltd. 


\title{
[Intervention Review] \\ Immunomodulators and immunosuppressants for multiple sclerosis: a network meta-analysis
}

\author{
Graziella Filippini $^{1}$, Cinzia Del Giovane ${ }^{2}$, Laura Vacchi ${ }^{3}$, Roberto D'Amico ${ }^{2}$, Carlo Di Pietrantonj ${ }^{4}$, Deirdre Beecher ${ }^{5}$, Georgia Salanti
}

${ }^{1}$ Neuroepidemiology Unit, Fondazione I.R.C.C.S. Istituto Neurologico Carlo Besta, Milano, Italy. ${ }^{2}$ Statistics Unit, Department of Clinical and Diagnostic Medicine and Public Health, University of Modena and Reggio Emilia, Modena, Italy. ${ }^{3}$ Institute of Experimental Neurology (INSPE), Scientific Institute and University Ospedale San Raffaele, Milano, Italy. ${ }^{4}$ Servizio Regionale di Riferimento per l'Epidemiologia, SSEpi-SeREMI - Cochrane Vaccines Field, Azienda Sanitaria Locale ASL AL, Alessandria, Italy. ${ }^{5}$ Cochrane Injuries Group, London School of Hygiene \& Tropical Medicine, London, UK. ${ }^{6}$ Department of Hygiene and Epidemiology, University of Ioannina School of Medicine, Ioannina, Greece

Contact address: Graziella Filippini, Neuroepidemiology Unit, Fondazione I.R.C.C.S. Istituto Neurologico Carlo Besta, via Celoria, 11, Milano, 20133, Italy. gfilippini@istituto-besta.it.

Editorial group: Cochrane Multiple Sclerosis and Rare Diseases of the Central Nervous System Group.

Publication status and date: New, published in Issue 6, 2013.

Review content assessed as up-to-date: 10 February 2012.

Citation: Filippini G, Del Giovane C, Vacchi L, D’Amico R, Di Pietrantonj C, Beecher D, Salanti G. Immunomodulators and immunosuppressants for multiple sclerosis: a network meta-analysis. Cochrane Database of Systematic Reviews 2013, Issue 6. Art. No.: CD008933. DOI: 10.1002/14651858.CD008933.pub2.

Copyright (C) 2013 The Cochrane Collaboration. Published by John Wiley \& Sons, Ltd.

\begin{abstract}
A B S T R A C T
Background

Different therapeutic strategies are available for treatment of multiple sclerosis (MS) including immunosuppressants, immunomodulators, and monoclonal antibodies. Their relative effectiveness in the prevention of relapse or disability progression is unclear due to the limited number of direct comparison trials. A summary of the results, including both direct and indirect comparisons of treatment effects, may help to clarify the above uncertainty.

\section{Objectives}

To estimate the relative efficacy and acceptability of interferon ß-1b (IFNß-1b) (Betaseron), interferon $\beta$-1a (IFNß-1a) (Rebif and Avonex), glatiramer acetate, natalizumab, mitoxantrone, methotrexate, cyclophosphamide, azathioprine, intravenous immunoglobulins, and long-term corticosteroids versus placebo or another active agent in participants with MS and to provide a ranking of the treatments according to their effectiveness and risk-benefit balance.
\end{abstract}

\section{Search methods}

We searched the Cochrane Database of Systematic Reviews, the Cochrane MS Group Trials Register, and the Food and Drug Administration (FDA) reports. The most recent search was run in February 2012.

\section{Selection criteria}

Randomized controlled trials (RCTs) that studied one of the 11 treatments for use in adults with MS and that reported our pre-speci fi ed efficacy outcomes were considered for inclusion.

Immunomodulators and immunosuppressants for multiple sclerosis: a network meta-analysis (Review)

Copyright $\odot 2013$ The Cochrane Collaboration. Published by John Wiley \& Sons, Ltd. 


\section{Data collection and analysis}

Identifying search results and data extraction were performed independently by two authors. Data synthesis was performed by pairwise meta-analysis and network meta-analysis that was performed within a Bayesian framework. The body of evidence for outcomes within the pairwise meta-analysis was assessed according to GRADE, as very low, low, moderate, or high quality.

\section{Main results}

Forty-four trials were included in this review, in which 17,401 participants had been randomised. Twenty-three trials included relapsingremitting MS (RRMS) (9096 participants, 52\%), 18 trials included progressive MS (7726, 44\%), and three trials included both RRMS and progressive MS (579, 3\%). The majority of the included trials were short-term studies, with the median duration being 24 months. The results originated mostly from 33 trials on IFNß, glatiramer acetate, and natalizumab that overall contributed outcome data for 9881 participants $(66 \%)$.

From the pairwise meta-analysis, there was high quality evidence that natalizumab and IFNß-1a (Rebif) were effective against recurrence of relapses in RRMS during the first 24 months of treatment compared to placebo (odds ratio (OR) $0.32,95 \%$ confidence interval (CI) 0.24 to 0.43 ; OR $0.45,95 \%$ CI 0.28 to 0.71 , respectively); they were more effective than IFNß-1a (Avonex) (OR 0.28 , $95 \%$ CI 0.22 to 0.36 ; OR 0.19 , 95\% CI 0.06 to 0.60 , respectively). IFNß-1b (Betaseron) and mitoxantrone probably decreased the odds of the participants with RRMS having clinical relapses compared to placebo (OR 0.55, 95\% CI 0.31 to 0.99; OR 0.15, $95 \%$ CI 0.04 to 0.54 , respectively) but the quality of evidence for these treatments was graded as moderate. From the network meta-analysis, the most effective drug appeared to be natalizumab (median OR versus placebo $0.29,95 \%$ credible intervals (CrI) 0.17 to 0.51 ), followed by IFNß-1a (Rebif) (median OR versus placebo $0.44,95 \%$ CrI 0.24 to 0.70 ), mitoxantrone (median OR versus placebo 0.43 , $95 \%$ CrI 0.20 to 0.87 ), glatiramer acetate (median OR versus placebo $0.48,95 \%$ CrI 0.38 to 0.75 ), IFNß-1b (Betaseron) (median OR versus placebo $0.48,95 \% \mathrm{CrI} 0.29$ to 0.78 ). However, our confidence was moderate for direct comparison of mitoxantrone and IFNB-1b vs placebo and very low for direct comparison of glatiramer vs placebo. The relapse outcome for RRMS at three years' follow-up was not reported by any of the included trials.

Disability progression was based on surrogate markers in the majority of included studies and was unavailable for RRMS beyond two to three years. The pairwise meta-analysis suggested, with moderate quality evidence, that natalizumab and IFNß-1a (Rebif) probably decreased the odds of the participants with RRMS having disability progression at two years' follow-up, with an absolute reduction of $14 \%$ and $10 \%$, respectively, compared to placebo. Natalizumab and IFNß-1b (Betaseron) were significantly more effective (OR 0.62 , 95\% CI 0.49 to 0.78 ; OR 0.35 , 95\% CI 0.17 to 0.70 , respectively) than IFNß-1a (Avonex) in reducing the number of the participants with RRMS who had progression at two years' follow-up, and confidence in this result was graded as moderate. From the network meta-analyses, mitoxantrone appeared to be the most effective agent in decreasing the odds of the participants with RRMS having progression at two years' follow-up, but our confidence was very low for direct comparison of mitoxantrone vs placebo. Both pairwise and network meta-analysis revealed that none of the individual agents included in this review were effective in preventing disability progression over two or three years in patients with progressive MS.

There was not a dose-effect relationship for any of the included treatments with the exception of mitoxantrone.

\section{Authors' conclusions}

Our review should provide some guidance to clinicians and patients. On the basis of high quality evidence, natalizumab and IFNß-1a (Rebif) are superior to all other treatments for preventing clinical relapses in RRMS in the short-term (24 months) compared to placebo. Moderate quality evidence supports a protective effect of natalizumab and IFNß-1a (Rebif) against disability progression in RRMS in the short-term compared to placebo. These treatments are associated with long-term serious adverse events and their benefit-risk balance might be unfavourable. IFNß-1b (Betaseron) and mitoxantrone probably decreased the odds of the participants with RRMS having relapses, compared with placebo (moderate quality of evidence). The benefit-risk balance with azathioprine is uncertain, however this agent might be effective in decreasing the odds of the participants with RRMS having relapses and disability progression over 24 to 36 months, compared with placebo. The lack of convincing efficacy data shows that IFNß-1a (Avonex), intravenous immunoglobulins, cyclophosphamide and long-term steroids have an unfavourable benefit-risk balance in RRMS. None of the included treatments are effective in decreasing disability progression in patients with progressive MS. It is important to consider that the clinical effects of all these treatments beyond two years are uncertain, a relevant point for a disease of 30 to 40 years duration. Direct head-to-head comparison(s) between natalizumab and IFNß-1a (Rebif) or between azathioprine and IFNß-1a (Rebif) should be top priority on the research agenda and follow-up of the trial cohorts should be mandatory. 


\section{PLAIN LANGUAGE SUMMARY}

Comparative efficacy and risk-benefit balance of modulator and suppressant drugs of the immune system in people with multiple sclerosis (MS)

Several immunotherapies have been used to treat MS, but their relative effectiveness is unclear due to the limited number of direct comparison studies. The authors of this review tried to assess the efficacy and the extent of adverse events of immunotherapies commonly used in people with MS. Eleven agents were studied, interferon B-1b (IFNß-1b) (Betaseron), IFNß-1a (Rebif and Avonex), glatiramer acetate, natalizumab, mitoxantrone, methotrexate, cyclophosphamide, azathioprine, immunoglobulins, and long-term corticosteroids.

Forty-four studies up to 2010 have been included in this review, comprising a total of 17,401 adults suffered from the relapsingremitting (RRMS) and the progressive types (PrMS) of MS. The treatments were short-term, the median duration being 24 months.

The results show that:

- there is high quality evidence that both natalizumab and IFNß-1a (Rebif) can reduce relapses and disability progression compared to placebo; and they are also more effective than IFNß-1a (Avonex) in people with RRMS. Natalizumab can induce progressive multifocal leukoencephalopathy, especially with more than two years of treatment;

- IFNß-1b (Betaseron), glatiramer acetate, and mitoxantrone may also prevent relapse and disability progression in people with RRMS. These treatments are associated with possible medium and long-term side effects, and the risk-benefit balance might be unfavourable;

- IFNß-1a (Avonex), intravenous immunoglobulins, cyclophosphamide, and long-term corticosteroids have an unfavourable riskbenefit balance for people with RRMS;

- there are insufficient high quality data to clarify whether there is a favourable risk-benefit balance using azathioprine;

- nine drugs (IFNß-1b (Betaseron), IFNß-1a (Avonex and Rebif), glatiramer acetate, mitoxantrone, methotrexate, cyclophosphamide, intravenous immunoglobulins, and long-term corticosteroids) were also studied in people with PrMS. Few studies were of high quality and no drug was shown to be effective in preventing disability progression in people with PrMS.

It is important to consider that the efficacy and the risk-benefit of all these treatments beyond two years are uncertain, and this is a very relevant point for a lifetime disease such as MS. Thus, studies on the long-term efficacy and safety of immunotherapies for MS are urgently needed. It is also worth considering that more than $70 \%$ of the included studies were sponsored by pharmaceutical companies. This could have affected the results of this review.

Immunomodulators and immunosuppressants for multiple sclerosis: a network meta-analysis (Review) 


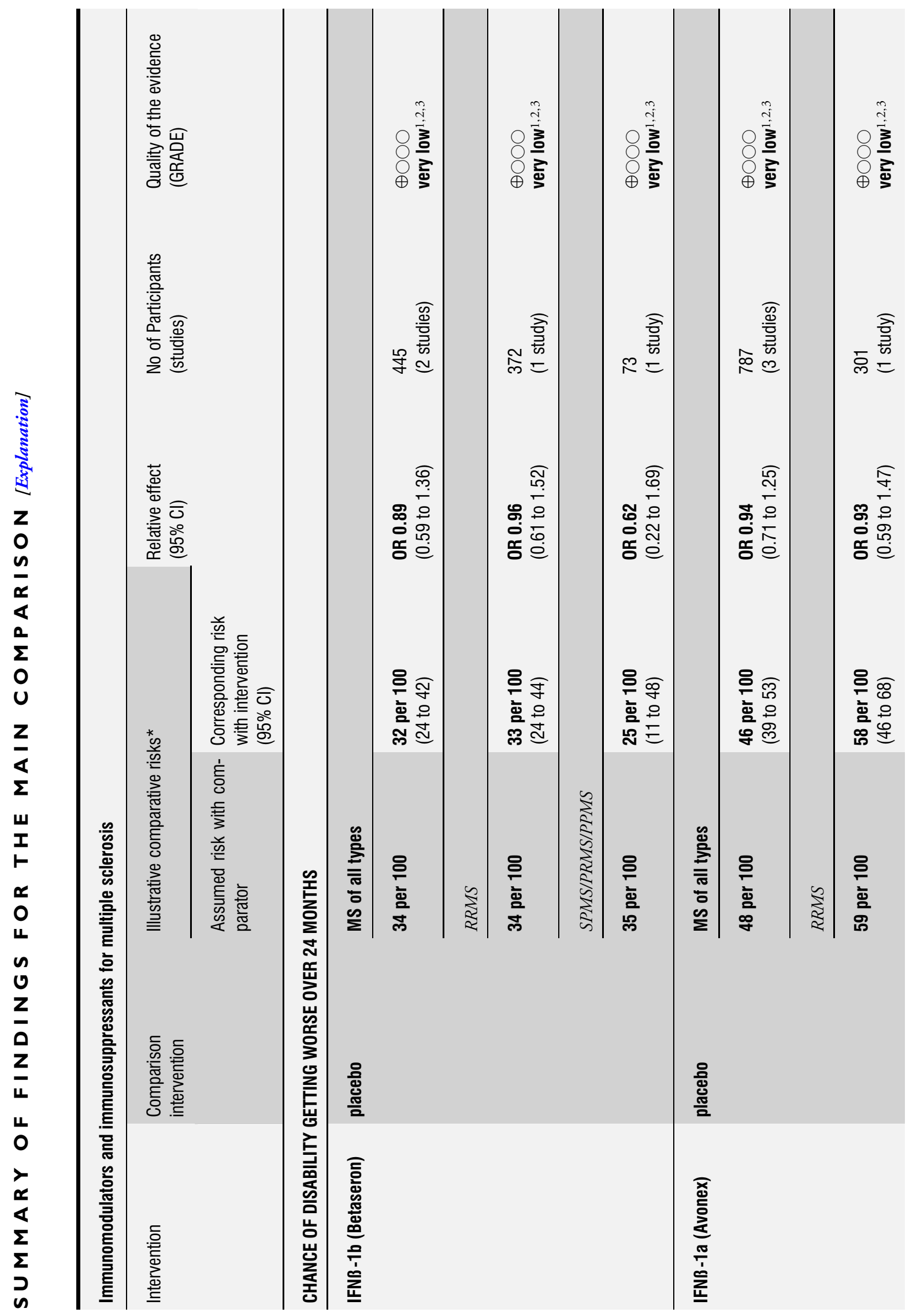

Immunomodulators and immunosuppressants for multiple sclerosis: a network meta-analysis (Review)

Copyright @ 2013 The Cochrane Collaboration. Published by John Wiley \& Sons, Ltd. 


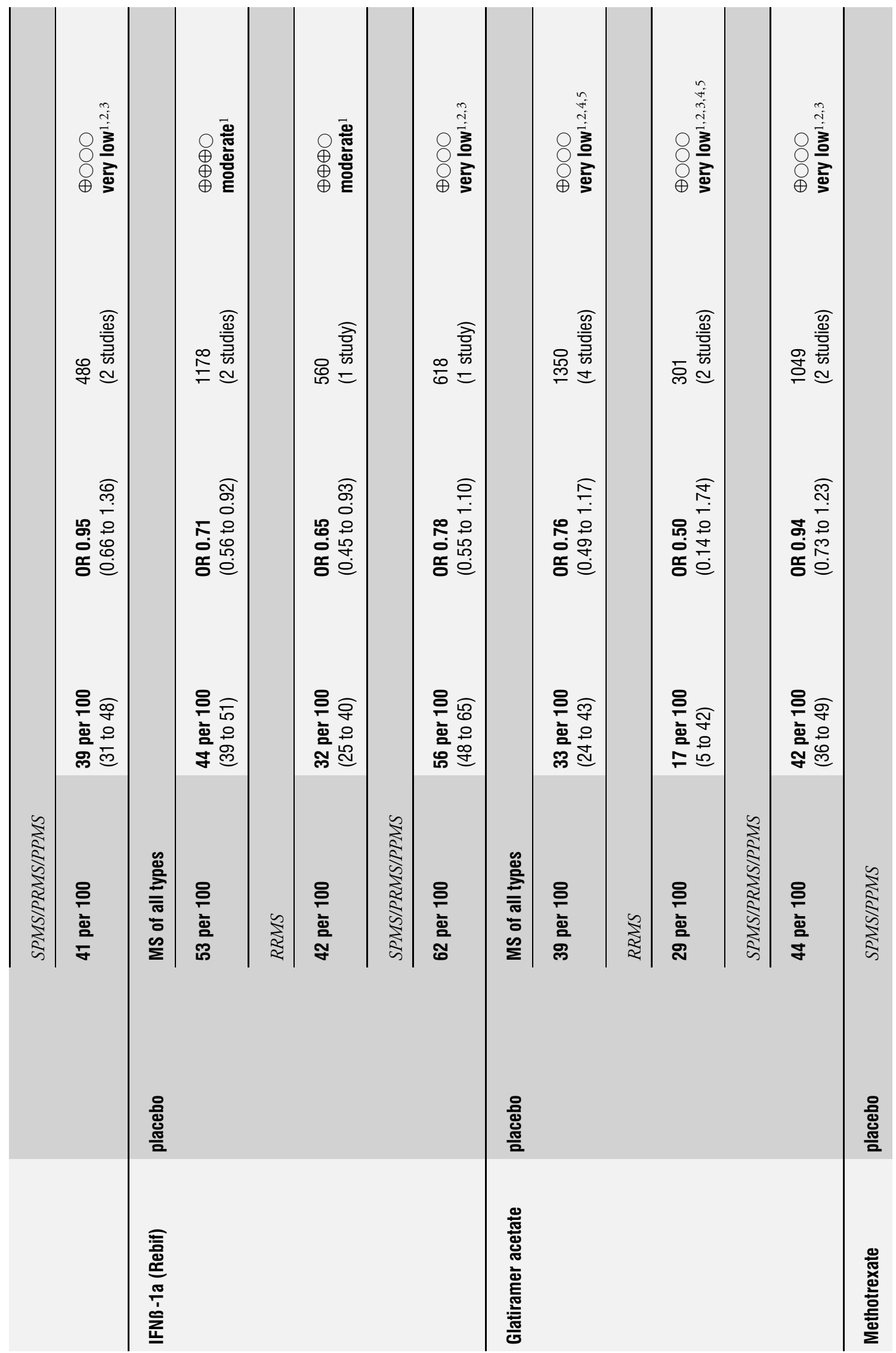

Immunomodulators and immunosuppressants for multiple sclerosis: a network meta-analysis (Review)

Copyright (c) 2013 The Cochrane Collaboration. Published by John Wiley \& Sons, Ltd. 


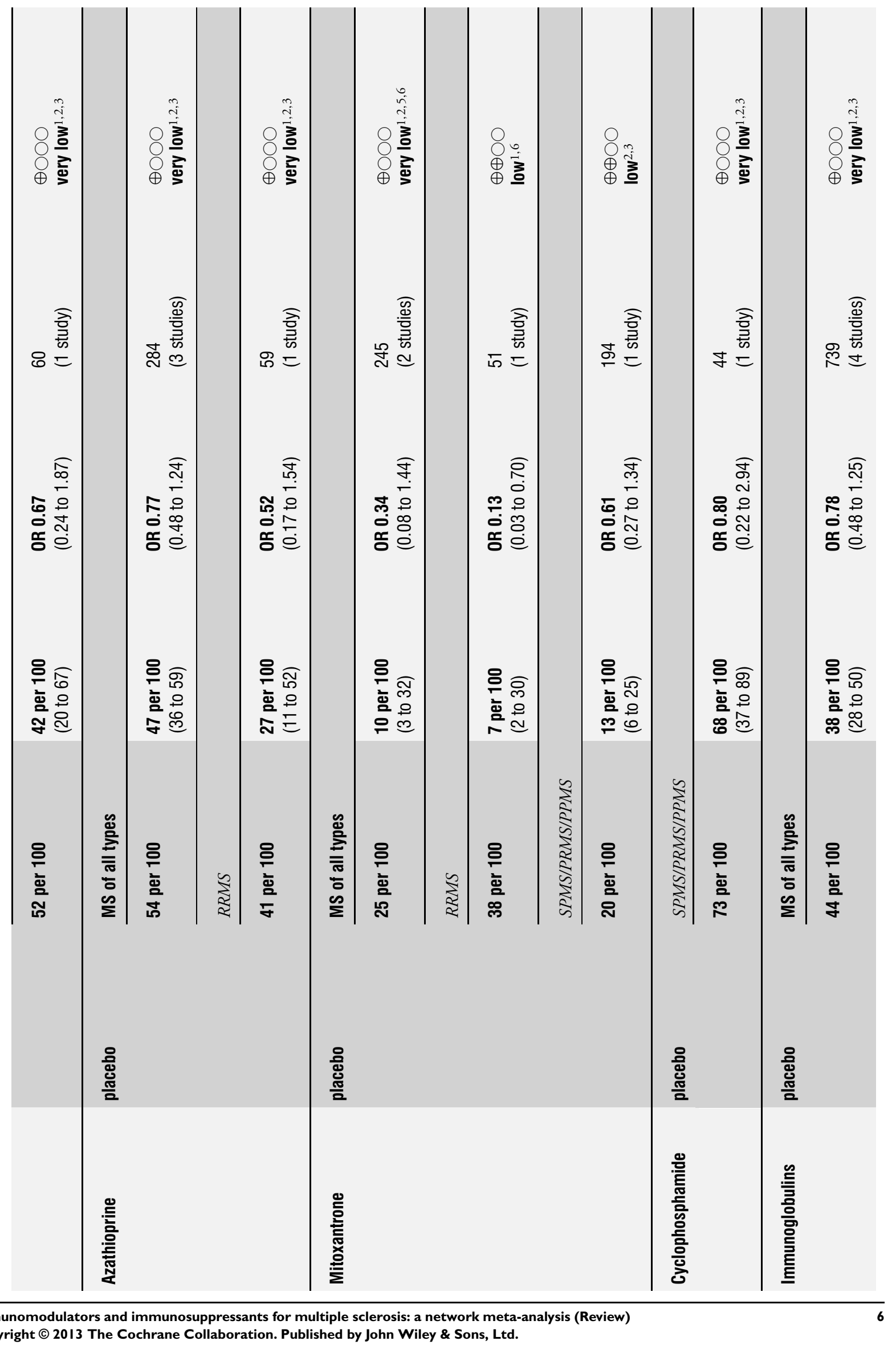

Copyright $\odot 2013$ The Cochrane Collaboration. Published by John Wiley \& Sons, Ltd. 


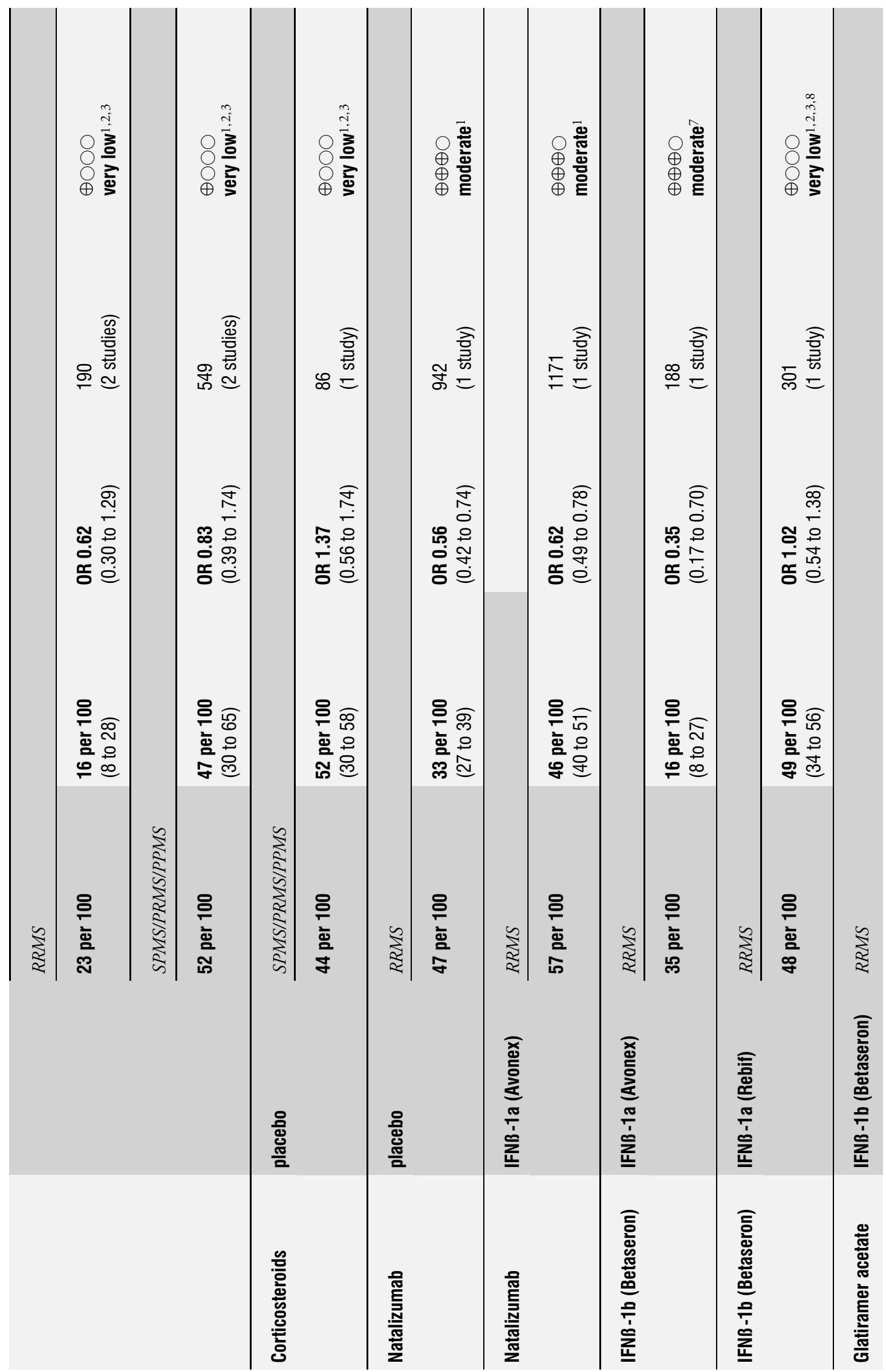

Immunomodulators and immunosuppressants for multiple sclerosis: a network meta-analysis (Review)

Copyright $\odot 2013$ The Cochrane Collaboration. Published by John Wiley \& Sons, Ltd. 


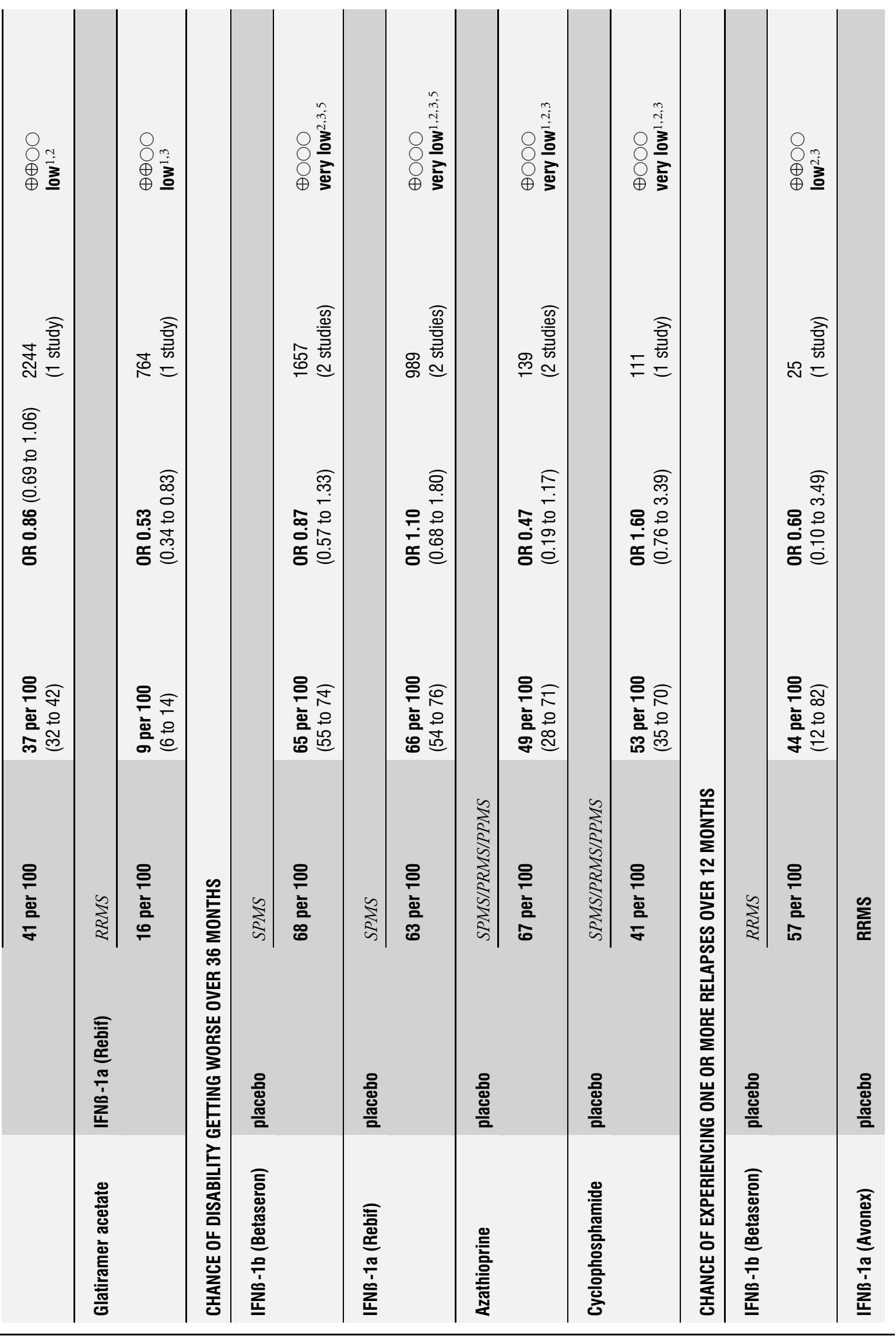

Immunomodulators and immunosuppressants for multiple sclerosis: a network meta-analysis (Review)

Copyright @ 2013 The Cochrane Collaboration. Published by John Wiley \& Sons, Ltd. 


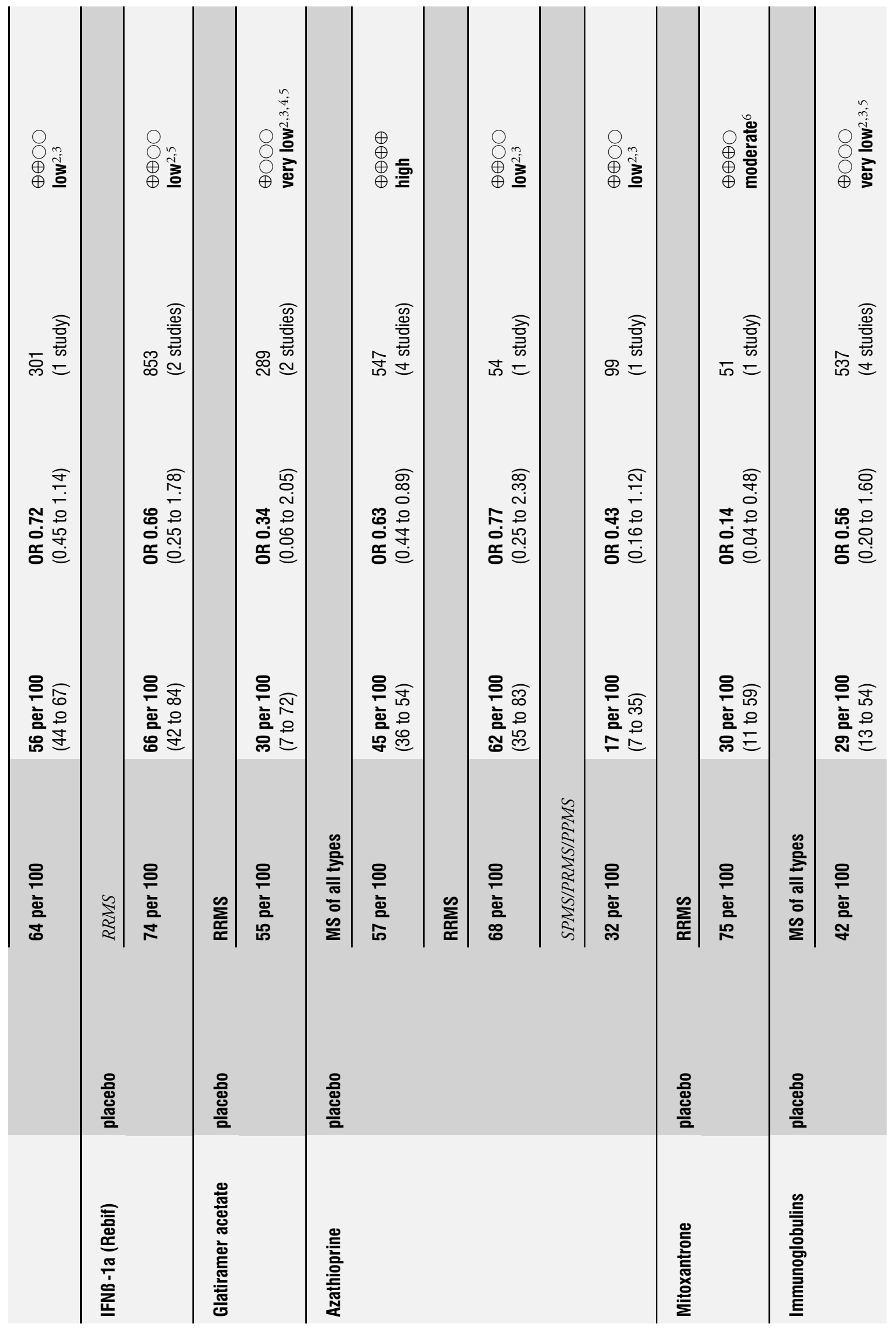

Immunomodulators and immunosuppressants for multiple sclerosis: a network meta-analysis (Review)

Copyright @ 2013 The Cochrane Collaboration. Published by John Wiley \& Sons, Ltd. 


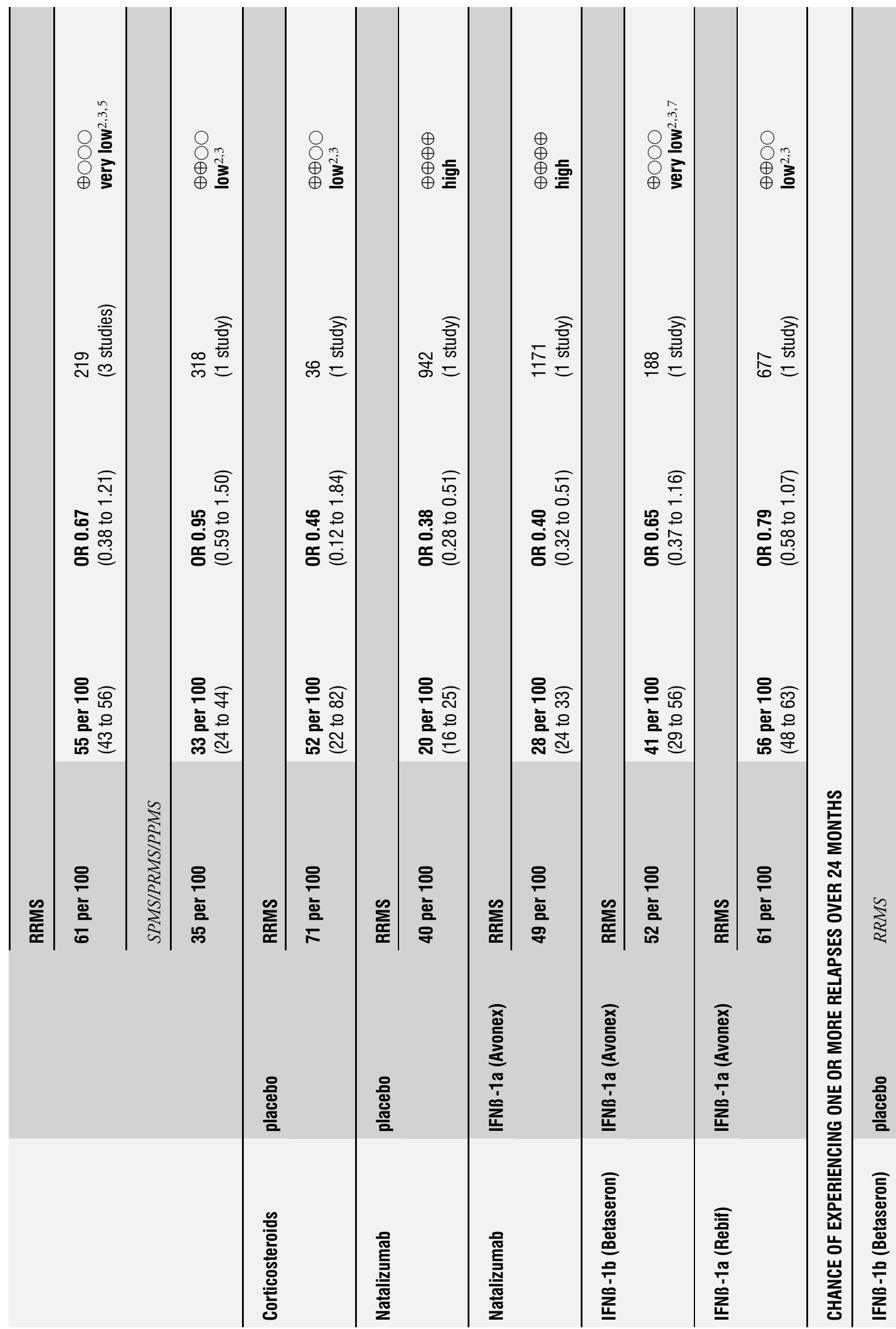

Immunomodulators and immunosuppressants for multiple sclerosis: a network meta-analysis (Review)

Copyright $\odot 2013$ The Cochrane Collaboration. Published by John Wiley \& Sons, Ltd. 


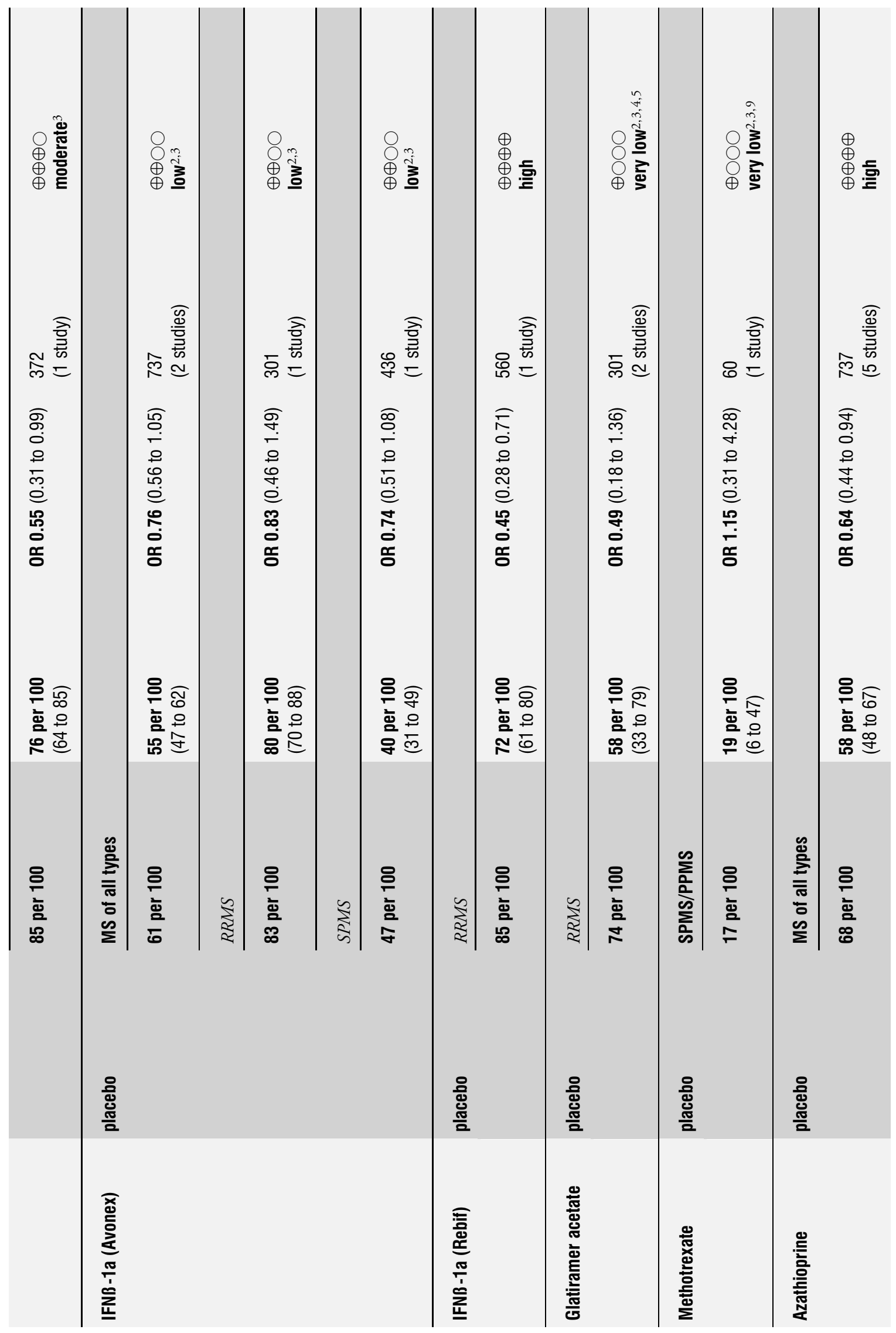

Immunomodulators and immunosuppressants for multiple sclerosis: a network meta-analysis (Review)

Copyright @ 2013 The Cochrane Collaboration. Published by John Wiley \& Sons, Ltd. 


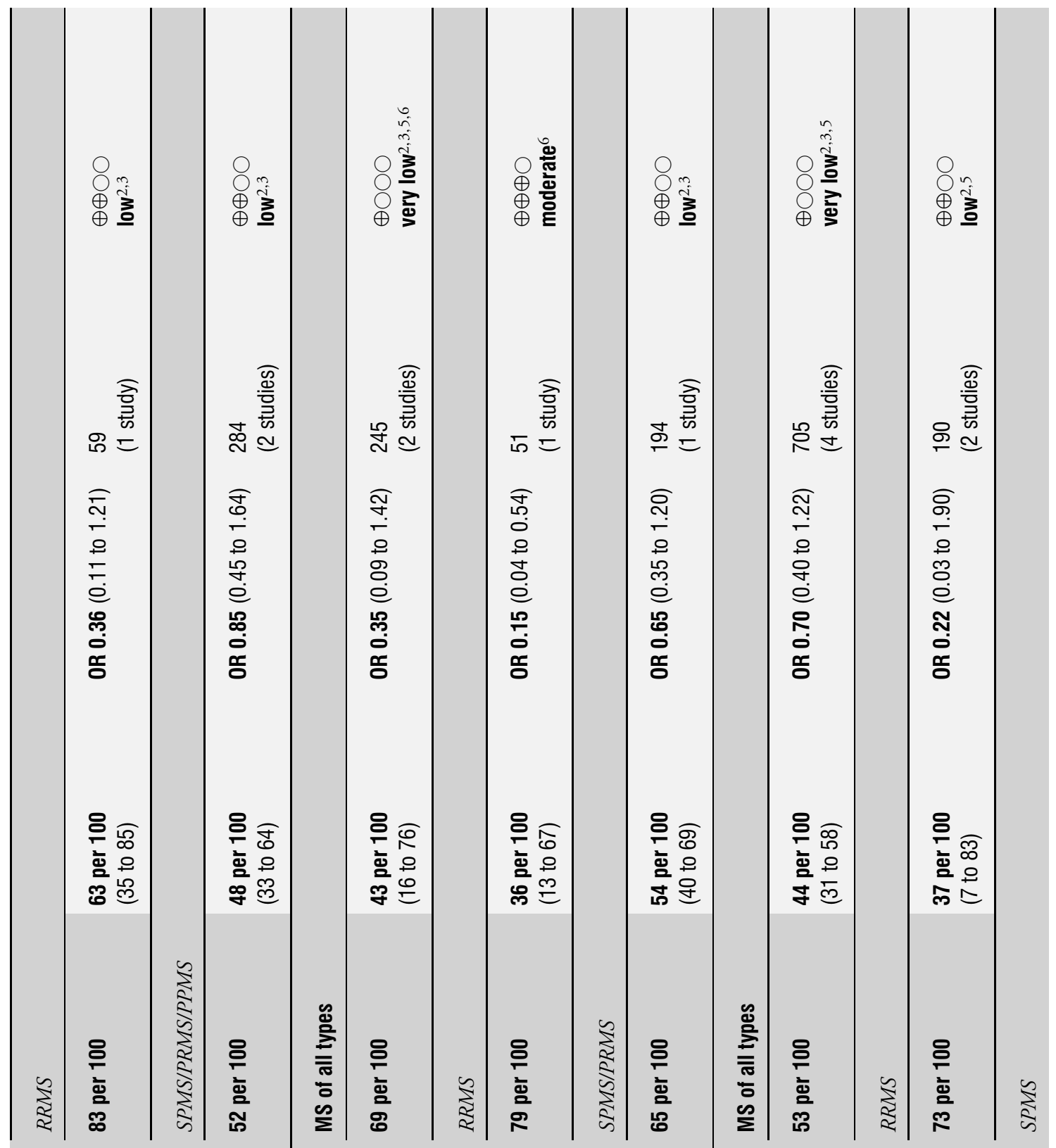

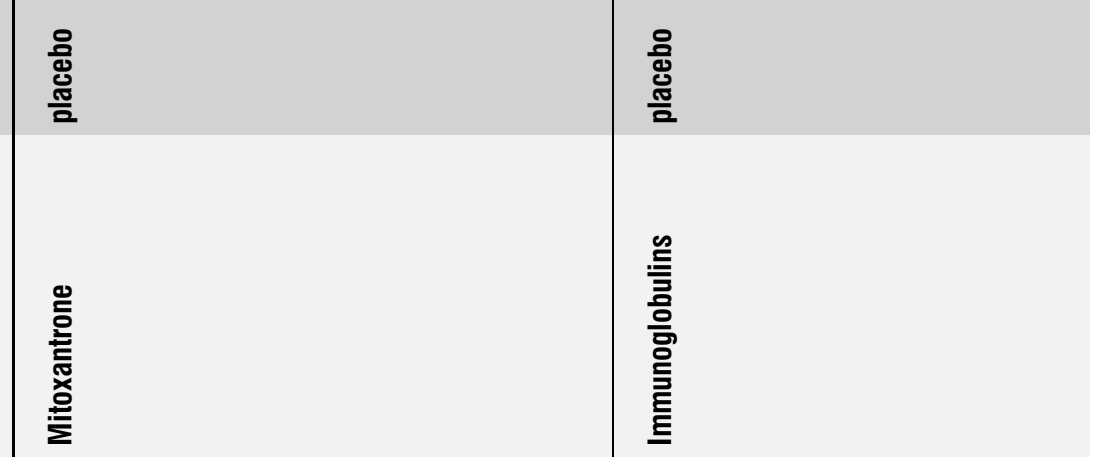

Immunomodulators and immunosuppressants for multiple sclerosis: a network meta-analysis (Review)

Copyright @ 2013 The Cochrane Collaboration. Published by John Wiley \& Sons, Ltd. 


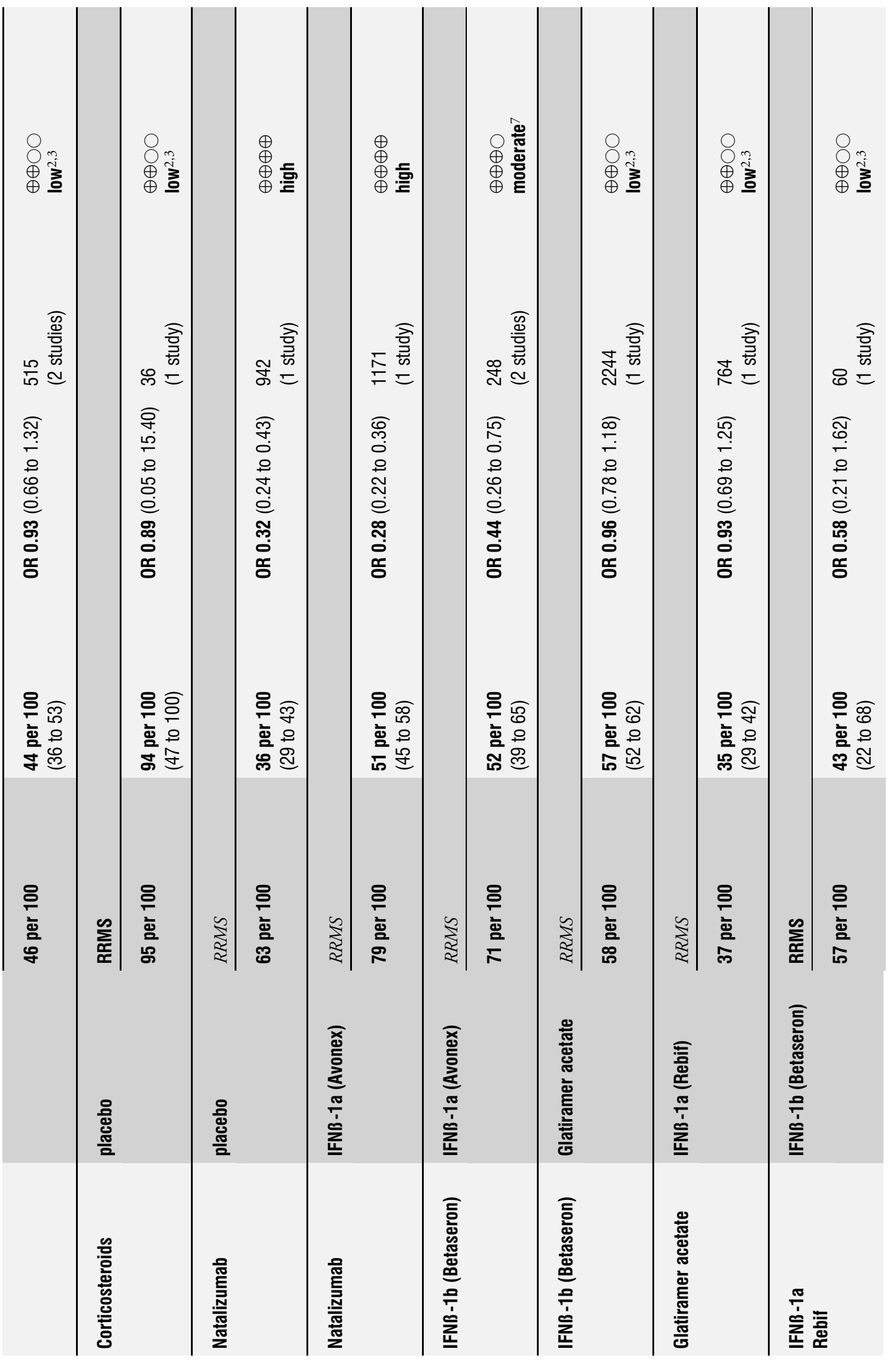

Immunomodulators and immunosuppressants for multiple sclerosis: a network meta-analysis (Review)

Copyright @ 2013 The Cochrane Collaboration. Published by John Wiley \& Sons, Ltd. 


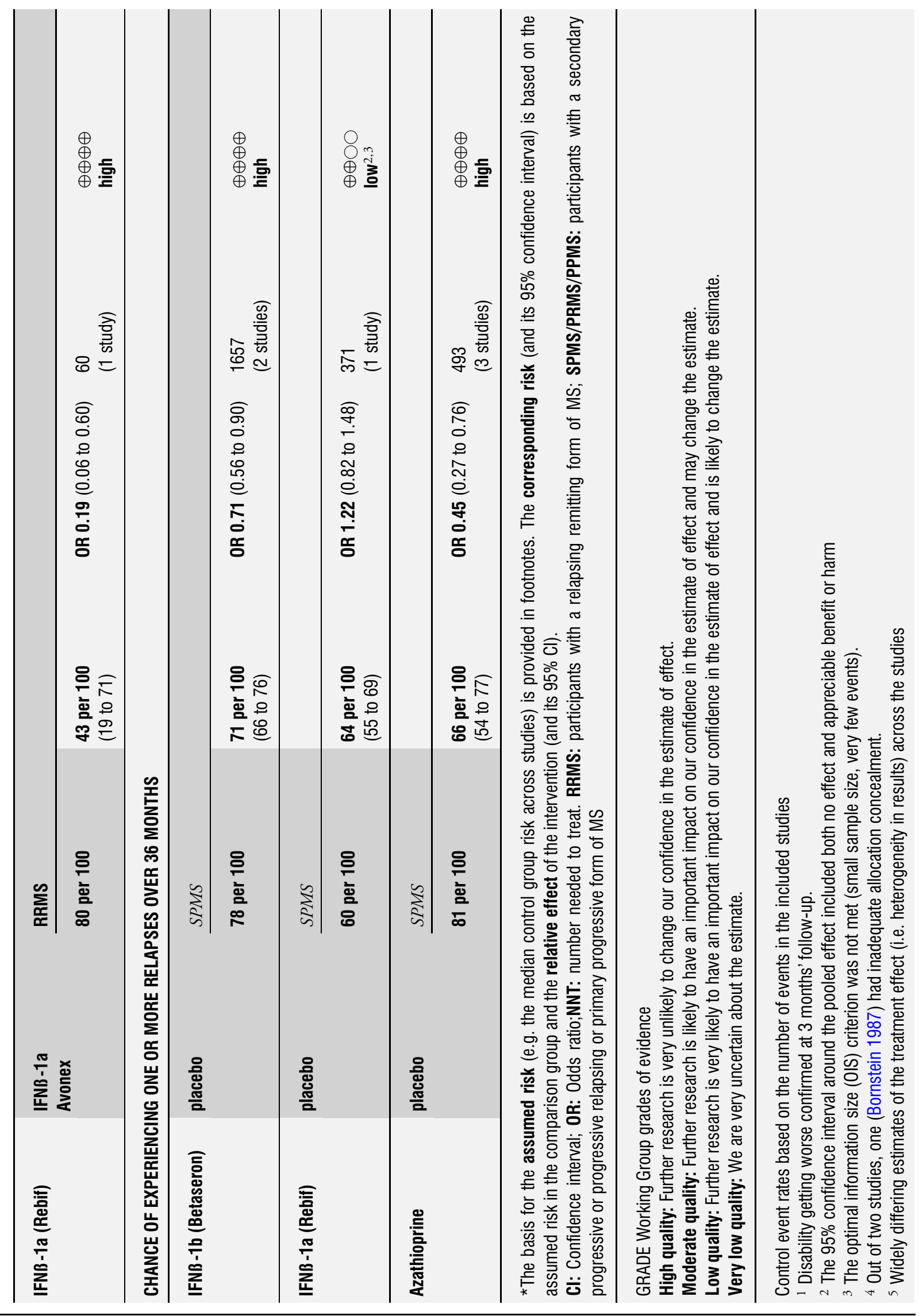

Immunomodulators and immunosuppressants for multiple sclerosis: a network meta-analysis (Review)

Copyright $\odot 2013$ The Cochrane Collaboration. Published by John Wiley \& Sons, Ltd. 


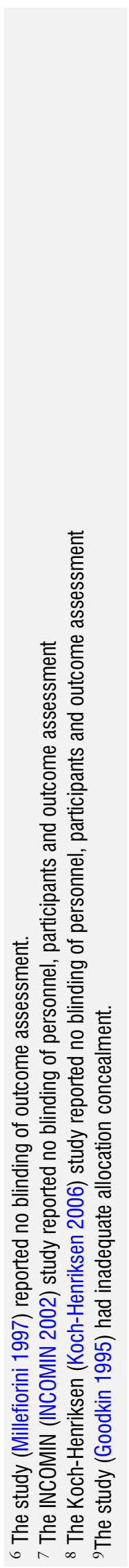

Immunomodulators and immunosuppressants for multiple sclerosis: a network meta-analysis (Review)

Copyright @ 2013 The Cochrane Collaboration. Published by John Wiley \& Sons, Ltd. 


\section{B A C K G RO U N D}

\section{Description of the condition}

Multiple sclerosis (MS) is an inflammatory disease of the central nervous system (CNS) resulting from the effect of an interaction between unidentified environmental factors and susceptibility genes (Milo 2010). Several pathological processes occur in MS, including engagement of the immune system, T cell-mediated and $B$ cell-mediated mechanisms, demyelination, inflammatory injury of axons and glia, post-inflammatory gliosis, and neurodegeneration (Bennett 2009; Vercellino 2009). The sequential involvement of these processes influences the clinical course, characterized by attacks with recovery, attacks leaving persistent deficits, and progression that causes fixed physical and cognitive disability (Compston 2002).

MS is among the commonest causes of neurological disability in young people, with an annual incidence ranging from 2 to 10 cases/ 100,000 persons/year and a north-south gradient, with a lower incidence closer to equator. Its clinical manifestations typically occur between 20 and 40 years of age, with symptoms and signs involving different CNS regions (optic nerve, brainstem, cerebellum, cerebral hemispheres, spinal cord) (Compston 2002).

MS has a chronic course evolving over 30 to 40 years. The clinical phenotypes include relapsing-remitting MS (RRMS), secondary progressive MS (SPMS), primary progressive MS (PPMS), and progressive-relapsing MS (PRMS) (Lublin 1996). The development of disease progression (SPMS, PRMS, PPMS) is responsible for permanent long-term disability and it supervenes in about $80 \%$ of RRMS participants after 20 to 25 years. After 15 to 18 years, about $50 \%$ of participants need assistance to walk, are confined to a wheelchair, bed, or have died (Kremenchutzky 2006). PPMS (approximately $10 \%$ of all participants with MS) is characterized, from the beginning, by a slow worsening of neurological deficits without experiencing attacks, and PRMS by a progressive course from onset with attacks and continuing progression (Lublin 1996). Natural history studies provide little support for the concept that progression is related primarily to a succession of attacks, indicating that attacks do not play a major role in longterm disability (Filippini 2007; Kremenchutzky 2006). Preventing progressive disability is the key therapeutic goal for MS.

\section{Description of the intervention}

Recombinant interferon $\beta-1 b$ (IFNß-1b) (Betaseron), IFNß-1a (Rebif and Avonex) and glatiramer acetate were approved by many national regulatory agencies (FDA 1993; FDA 1996; FDA 2001; EMEA 2002; FDA 2002; FDA 2003) and are available for use in MS free of charge from many national health services. Natalizumab is a recombinant monoclonal antibody that was approved for the treatment of RRMS (FDA 2004). Following the recognition of two cases of progressive multifocal leukoencephalopathy (PML) in patients who had been receiving natalizumab, its commercialisation was suspended. In July 2006 marketing of natalizumab resumed after an investigation of patients included in clinical trials (including trials carried on in patients with Crohn's disease) (Yousry 2006). Natalizumab was commercialised worldwide from that year on. Mitoxantrone was approved in 2000 (FDA 2000) under the description "for reducing neurological disability and/or the frequency of clinical relapses in patients with SPMS, PRMS or worsening RRMS". In March 2005, the US Food and Drug Administration (FDA 2005) warned about cardiotoxicity and therapy-related acute leukaemia in mitoxantrone-treated patients. In many countries azathioprine is used for the treatment of MS, however since the approval of IFNß for the same indication, azathioprine has not been recommended as a first line therapy (Goodin 2002). Intravenous immunoglobulins may have a role in patients with severe and frequent relapses for whom other treatments are contraindicated, but they should not be used routinely (Association of British Neurologists 2005). Severe adverse events leading to discontinuation of the treatment with intravenous immunoglobulins were noted in $4 \%$ of 84 treatment courses with a total 341 infusions under routine clinical conditions. These included thrombosis of the jugular vein, an allergic reaction, and retrosternal pressure (Elovaara 2008). Cyclophosphamide and methotrexate might benefit patients with progressive MS (Goodin 2002) but these agents are less commonly used because their toxicity is severe. Long-term pulsed regimens of corticosteroids may be effective for MS owing to their long-lasting immunosuppressive effect, and they are reported to be well-tolerated and safe with only minor, dose-related side effects (Pozzilli 2004).

\section{How the intervention might work}

Immunomodulator or immunosuppressive effects are common to all treatments included in this review. The exact mode of action of immunomodulators is unknown, but they are thought to target various immune cells or cytokines important in MS pathogenesis. The IFNß family have effects on the production of cytokines by $T$ helper lymphocytes, on migration of leukocytes across the blood-brain barrier, and have antiviral activity (Billiau 2004). Glatiramer acetate has a combined effect on anti-inflammatory T-cell populations and regulatory type II antigen-presenting cells (Lalive 2011). Natalizumab is a monoclonal antibody targeting an integrin that blocks adhesion and transmigration of lymphocytes through the vascular endothelium, thus avoiding inflammation (Fontoura 2010).

Immunosuppressant agents suppress immune function by one of several mechanisms of action; they also have anti-inflammatory activity. Azathioprine, cyclophosphamide, mitoxantrone, and methotrexate are classical cytotoxic immunosuppressants that act 
by inhibiting DNA synthesis. Azathioprine inhibits T-cell function (Tiede 2003); cyclophosphamide suppresses both cell-mediated and humoral immunity (Calabresi 1991); mitoxantrone reduces the number of B-cells, inhibits T-cells, and enhances T-cell suppressor activity (Fox 2004); methotrexate inhibits T-cell activation and suppresses intercellular adhesion molecule expression by T-cells (Johnston 2005). Corticosteroids have many immunological effects, they inhibit lymphocyte proliferation and the synthesis of most pro-inflammatory cytokines and cell surface molecules required for immune function (Sloka 2005). The mechanism of action of intravenous Immunoglobulins remains unclear although, through the mediation of the effects of cytokines, remyelination of demyelinated CNS axons may occur (Stangel 1999).

\section{Why it is important to do this review}

Although there is consensus that immunotherapies reduce the frequency of relapses in MS, their relative effectiveness in the prevention of new attacks or delaying disability progression remains unclear. This uncertainty is due to the limited number of direct comparison trials, which provide the most rigorous and valid research evidence on the relative efficacy and safety of different treatments for MS. A summary of the results of trials, including both direct and indirect comparisons, may help to clarify the above uncertainty (Caldwell 2005; Glenny 2005).

\section{O B JECT IVES}

To compare immunomodulators and immunosuppressants against placebo or against one another in terms of response and acceptability. Given the wide spectrum of available comparisons, we aimed to use the methodology of network meta-analysis, a method that allows the integration of data from direct comparisons (when treatments are directly compared within a randomised trial) and indirect comparisons (when treatments are compared between trials by combining results against a common comparator treatment) (Lu 2004; Caldwell 2005; Salanti 2008).

In summary, the aims of this overview were:

1. to estimate the relative effectiveness and acceptability of immunomodulators and immunosuppressants for MS;

2. to provide a ranking of the treatments according to their effectiveness and acceptability in order to inform clinical practice.

\section{METHODS}

\section{Criteria for considering studies for this review}

\section{Types of studies}

Randomised controlled trials (RCTs) that studied one of the agents for use in MS and that reported our pre-specified outcomes were evaluated for inclusion. Trials for which it was unclear whether the method of randomisation provided adequate allocation concealment or open label studies were also included, but the quality of these studies was taken into account. RCTs with follow-up less than six months were excluded. Quasi-randomised trials and nonrandomised studies were excluded.

\section{Types of participants}

Participants 18 years age or older with a diagnosis of MS were included. Only RCTs adopting the Poser (Poser 1983) or McDonald diagnostic criteria (McDonald 2001; Polman 2005) were selected. We included all phenotypes: relapsing-remitting MS (RRMS); secondary progressive MS (SPMS); progressive-relapsing MS (PRMS); and primary progressive MS (PPMS), regardless of age, sex, degree of disability, and duration of the disease.

\section{Types of interventions}

Interferon $\beta-1 b$ (IFNß-1b), IFNß-1a (Rebif, Avonex), glatiramer acetate, natalizumab, mitoxantrone, methotrexate, cyclophosphamide, azathioprine, immunoglobulins, and long-term corticosteroids versus placebo or versus another active agent. Regimens were included irrespective of their dose as long as it was within therapeutic range. IFNß-1b, IFNß-1a (Rebif) and glatiramer acetate are administered by subcutaneous injection; IFNß-1a (Avonex) by intramuscular injection; natalizumab, mitoxantrone, cyclophosphamide, immunoglobulins by the intravenous route; methotrexate and azathioprine orally. Corticosteroids are administered intravenously or by the oral route.

\section{Types of outcome measures}

\section{Primary outcomes}

\section{Efficacy}

Two primary outcomes were considered.

1. Clinical relapses: proportion of participants who experienced new relapses over 12, 24, or 36 months after randomisation or at the end of the study. A relapse is defined as newly developed or recently worsened symptoms of neurologic dysfunction that last more than 24 hours, occurring in the absence of fever or other acute diseases, and separated in time from any previous episode by more than 30 days (McDonald 2001). A relapse resolves either partially or completely.

2. Disability progression: proportion of participants who experienced disability progression over 24 or 36 months after randomisation or at the end of the study. Disability progression 
is defined as at least 1 point Expanded Disability Status Scale (EDSS) (Kurtzke 1983) increase, or a 0.5 point increase if the baseline EDSS was $\geq 5.5$, confirmed during two subsequent neurological examinations separated by an interval of at least six months free of attacks. The EDSS is a common measure of MS disability (where 0 is normal, 3 mild disability, 6 care requirement, 7 wheelchair use, and 10 is death from MS). It is frequently used to measure disability progression in clinical trials.

\section{Acceptability}

Treatment discontinuation was used to assess acceptability and was measured by the dropout rate, that is the proportion of participants who were lost to follow-up or definitely discontinued treatment (withdrawals) but completed follow-up, out of the total number of participants randomly assigned to each treatment arm.

\section{Secondary outcomes}

\author{
Adverse events (AE) \\ Number of participants with: \\ a) at least one $\mathrm{AE}$; \\ b) at least one serious $\mathrm{AE}$ (SAE), as defined by the authors of the \\ primary study; \\ c) withdrawal due to $\mathrm{AE}$ at any time during the follow-up period; \\ d) serious infections, as defined by the authors of the primary \\ study; \\ e) a new diagnosis of leukaemia, lymphoma, or any other type of \\ cancer during the follow-up period.
}

\section{Search methods for identification of studies}

No language restrictions were applied.

\section{Electronic searches}

1. We searched the Cochrane Database of Systematic Reviews (CDSR) (Issue 1 of 12, 2012) (Appendix 1).

Cochrane Multiple Sclerosis Systematic Reviews (SRs) retrieved:

1. Azathioprine for multiple sclerosis (Casetta 2007);

2. Corticosteroids for the long term treatment in multiple sclerosis (Ciccone 2008);

3. Cyclophosphamide for multiple sclerosis (La Mantia 2007);

4. Glatiramer acetate for multiple sclerosis (La Mantia 2010);

5. Interferon in relapsing-remitting multiple sclerosis (Rice 2001);

6. Interferon beta for primary progressive multiple sclerosis (Rojas 2010);

7. Interferon beta for secondary progressive multiple sclerosis (La Mantia 2012);
8. Intravenous immunoglobulins for multiple sclerosis (Gray 2003);

9. Methotrexate for multiple sclerosis (Gray 2004);

10. Mitoxantrone for multiple sclerosis (Martinelli 2005);

11. Natalizumab for relapsing-remitting multiple sclerosis (Pucci 2011).

Updated searches were run, for out of date reviews to retrieve primary RCTs, which were limited from the date of their most recent search to February 2012. The search strategies used are those reported in the published reviews.

2. We searched the Cochrane Multiple Sclerosis Specialised Register (February 2012) for direct comparison trials. Keywords for each comparison are listed in Appendix 2. For information about the Cochrane Multiple Sclerosis Review Group Trials Register please see: Cochrane Multiple Sclerosis Group.

3. We searched the Food and Drug Administration (FDA) reports on all the treatments included in this review (www.fda.gov) (February 2012).

\section{Searching other resources}

Reference lists of published reviews and retrieved articles were checked for additional trials.

\section{Data collection and analysis}

\section{Selection of studies}

The reference lists of selected SRs were screened. If a review was not published in the CDSR, or it was incomplete or not updated, titles and abstracts from the search results were independently assessed by the two review authors to identify relevant trials for inclusion. The full text of the study was obtained, when necessary, to confirm inclusion. Trials were selected if they met the pre-specified eligibility criteria. Discrepancies in judgements were resolved by discussion among the two review authors (LV, GF).

\section{Data extraction and management}

Two review authors (GF, LV) independently extracted data using a predefined data extraction form. If outcomes were not reported at the predefined time points, we extracted data as close as possible to that time point. Trial arms involving the same agent at different fixed doses within the therapeutic range were converted into a single arm by summing the number of events and the sample size. Disagreements were resolved by discussion between the two review authors. Data were extracted from:

1) the Cochrane SRs and additional information from the original RCT reports, when necessary;

2) the original RCTs for treatments that were not included in published Cochrane SRs or for direct comparison trials; 
3) FDA reports, which were consulted in order to obtain further details on study characteristics or outcomes if these data were unclearly presented in the original articles.

\section{Assessment of risk of bias in included studies}

The risk of bias (RoB) was assessed for each included study using the Cochrane Collaboration criteria (Higgins 2011). These included: random sequence generation, allocation concealment, blinding of participants and outcome assessment, incomplete outcome data, and selective outcome reporting. Other potential sources of RoB were: sustained disability progression measured after only three months' follow-up, that is a surrogate marker for unremitting disability (Ebers 2008), and role of the sponsor. The RoB of each study was explicitly judged on each criterion and classified as 'low', 'high', or 'unclear'. Complete outcome data were judged as 'low risk' when the percentage of participants lost to follow-up was low (arbitrarily set at values lower than 15\%) and when numbers and causes of losses to follow-up were balanced between arms. Regarding selective outcome reporting bias, we assigned 'high risk' when one or more outcomes of interest were not reported or were presented incompletely and they could not be analysed quantitatively.

To summarize the RoB overall for a study, we considered allocation concealment, blinding of outcome assessment, and incomplete outcome data in order to classify each study as: 'low risk of bias' when all three criteria were met; 'high risk of bias' when at least one criterion was unmet; and 'moderate risk of bias' in the remaining cases. Allocation concealment, blinding of outcome assessment, and incomplete outcome data were not expected to vary in importance across the two primary efficacy outcomes (relapses and progression), and therefore we summarized the RoB of each study considering the two outcomes together.

We assessed RoB for adverse events (AE) by considering specific factors that may have had a large influence on the adverse events data. We evaluated methods for monitoring and detecting an $\mathrm{AE}$ for each study: did the researchers actively monitor for AEs (low risk of bias), or did they simply provide spontaneous reporting of AEs that arose (high risk of bias)? Did the authors define serious $\mathrm{AE}$ according to an accepted international classification and report the number of SAEs?

The RoB of each study was assessed independently by the two review authors (GF, LV) and any disagreement was resolved by discussion to reach consensus.

\section{Measures of treatment effect}

For each pairwise comparison and each outcome at each time point, we used odds ratio (OR) with $95 \%$ confidence interval (95\% CI) as a measure of the association between the treatment used and efficacy. As the outcomes are negative, ORs $<1$ correspond to beneficial treatment effects of the first treatment compared with the second treatment.

\section{Unit of analysis issues}

Our unit of data extraction, evaluation, and analysis was the primary randomised trial.

\section{Dealing with missing data}

In order to assess the effect of patient withdrawal or loss to followup on primary outcomes, we extracted data according to a likely scenario, that is we assumed that the treated- and control-group participants who dropped out and were not included in the study analysis both had the outcome (relapse or disability progression).

\section{Assessment of heterogeneity}

Heterogeneity or inconsistency can be the result of an uneven distribution of important clinical and methodological effect modifiers across studies (heterogeneity) or across comparisons (inconsistency). The presence of statistical heterogeneity was assessed by visual inspection of the forest plots and by calculating the $\mathrm{I}^{2}$ statistic and its confidence limits. Potential sources of heterogeneity or inconsistency include: different participant baseline characteristics (MS phenotype), different treatment dose, influence of funders. We investigated the distribution of these characteristics and carried out a subgroup analysis for the efficacy outcomes at each time point.

\section{Assessment of reporting biases}

The possibility of reporting bias in network meta-analysis was evaluated by means of an adaptation of the funnel plot for pairwise meta-analysis, the 'comparison-adjusted' funnel plot (Chaimani 2012). In a network of interventions each study estimates the relative effect of different interventions, so asymmetry in the funnel plot could not be judged. To account for this, we subtracted from each study-specific log odds-ratio of an active treatment versus placebo the mean of the meta-analysis for the same comparison and plotted it against the study's standard error. We drew funnel plots for the efficacy outcomes at 24 and 36 months and acceptability for all interventions versus placebo. As with regular funnel plots, asymmetry might be caused by publication bias but other reasons such as true heterogeneity are also possible. We used the STATA routines available in www.mtm.uoi.gr to create the comparison-adjusted funnel plots.

\section{Data synthesis}

First, conventional pairwise meta-analyses was conducted for all outcomes and comparisons, provided that at least two studies were available, using a random-effects model (DerSimonian 1986). We then performed a network meta-analysis for primary outcomes (relapses, progression, and dropouts). Network meta-analysis is a method of synthesizing information from a network of 
trials addressing the same question but involving different interventions. For a given comparison, say A versus B, direct evidence is provided by studies that compare these two treatments directly. In addition, indirect evidence for the A versus B comparison can be provided by synthesizing studies that compare $\mathrm{A}$ versus C and B versus C (Higgins 1996; Caldwell 2005). Network meta-analysis combines direct and indirect evidence across a network of randomised trials into a single effect size, and under certain assumptions it can increase the precision in the estimates while randomisation is respected. We performed network meta-analyses within a Bayesian framework, assuming an equal heterogeneity parameter $\tau$ across all comparisons, and we accounted for correlations induced by multi-arm studies (Lu 2006; Salanti 2009). The analysis was performed using WinBUGS (MRC Biostatistics Unit, Cambridge, UK) (http://www.mrcbsu.cam.ac.uk/bugs/winbugs/contents.shtml); the codes and description of the methodology can be found at www.mtm.uoi.gr/ howtodoanmtm.html. We used a normal prior with zero mean and variance one restricted to positive values for the common heterogeneity standard deviation $\tau$ and non-informative vague priors for all mean parameters, otherwise referred as treatment effects. As a measure that reflects ranking and the uncertainty, we used the Surface Under the Cumulative RAnking curve (SUCRA) as described in Salanti 2011. This measure, expressed as percentage, showed the relative probability of an intervention being among the best options.

The adequacy of each model was evaluated by comparing the posterior deviance to the number of data points (they should be close for models that fit the data well) and by calculating the Deviance Information Criterion (DIC), which is a measure equivalent to Akaike's Information Criterion and penalizes model fit for complexity (lower values indicate better models) (Spiegelhalter 2002). There are limitations in the use of the network meta-analysis methodology and it is essential to check the assumptions of the analysis before drawing conclusions. The most important assumption is that the network of comparisons is consistent, meaning that direct and indirect evidence on the same comparisons agree. Joint analysis can be misleading if the network is substantially inconsistent. Inconsistency can be present if the trials in the network have very different protocols and their inclusion and exclusion criteria are not comparable, or may result from an uneven distribution of effect modifiers across groups of trials that compare different treatments.

In order to estimate network inconsistency we calculated the difference between indirect and direct estimates in each closed loop formed by the network of trials (using the Bucher method) and their relative $95 \%$ confidence interval (CI). Then we examined whether there were any material discrepancies; if the $95 \%$ CI did overlap with 0 the hypothesis of consistency was not rejected, as described in Salanti (Salanti 2009). The code to assess consistency is available at www.mtm.uoi.gr/howtodoanmtm.html. Further, we compared the DIC between the models with and without the con- sistency assumption; a lower DIC for the consistency model indicates that the consistency assumption is statistically supported. In the case of important clinical or statistical inconsistency being identified, we planned to investigate this further and possibly to adjust for potential effect modifiers using network meta-regression or relaxing the consistency assumption and extending the model as described in Lu and Ades (Lu 2006).

\section{Subgroup analysis and investigation of heterogeneity}

Subgroup analysis for the efficacy outcomes at each time point were based on the following.

1. Clinical phenotype, distinguishing two groups of participants: RRMS and SPMS, PRMS, PPMS.

2. Treatment dose: as we previously said, many immunotherapies exist for the management of MS and some of them are administered at different doses. However, it is still unclear whether the relative efficacy of the MS agents depends on the dose used and, in particular, whether some agents given at higher doses are more effective. For that reason, we explored whether the agent's efficacy on disability progression at 24 months was modulated by dose administration. For this purpose we considered the network formed of agents administered at different doses (so that each node in the network was a treatment at a different dose). Any specific dose used for each agent was transformed into a unique measure unit (mg) 'dose per week' (for example $0.02 \mathrm{mg}$ three times a week corresponded to a 'dose per week' equal to 0.06). The network was re-analysed and posterior ORs were summarized for each drug and dose. We compared the DICs between models where doses of the same agent were assumed to be equally effective with the DIC from models where each dose was assumed to be a different intervention. We also applied different assumptions regarding the association between dose effects, such as linear and monotonic. 3. Funders: sponsorship from pharmaceutical companies or independent trials.

\section{Sensitivity analysis}

The RoB in included studies was taken into account in the interpretation of evidence using the GRADE approach.

\section{Summary of findings table}

The main results of the review are presented in a summary of findings ( $\mathrm{SoF}$ ) table, as recommended by The Cochrane Collaboration (Schünemann 2011a). The SoF table was provided for the direct estimates only and included an overall grading of the evidence for relapses over 12, 24, and 36 months, and disability getting worse over 24 and 36 months. For each treatment, data were pooled across all types of MS, and the subgroups of RRMS and progressive MS. The SoF table includes an overall grading of the quality of evidence related to each of the outcomes, using the GRADE approach (Schünemann 2011b). Quality of evidence was graded 
as high, moderate, low, or very low, considering within-study RoB, directness of evidence, heterogeneity, precision of effect estimates, and risk of publication bias. The control event rates used in the calculation of absolute risks were based on the number of events in the included studies.

\section{RES U L T S}

\section{Description of studies}

\section{Results of the search}

Flow charts describe the results of the electronic search (Figure 1). Thirty-eight studies were identified in 11 reviews available from the Cochrane Database of Systematic Reviews (CDSR) and six studies were identified in the Cochrane Multiple Sclerosis Review Group Specialised Register.

Figure I. Study flow diagrams

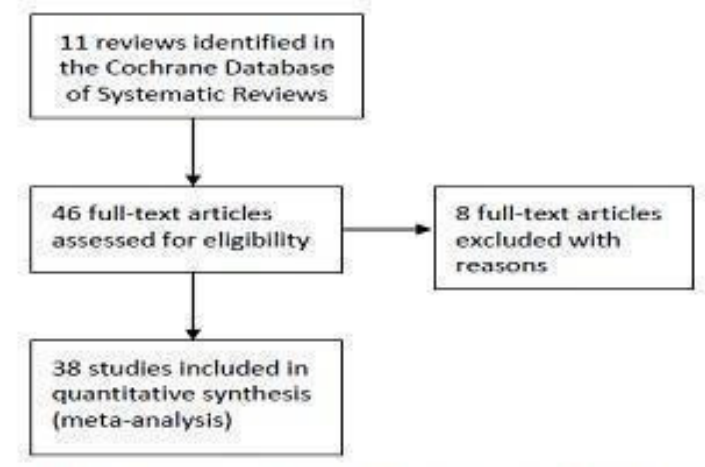

Study fow diagram for search in CDSR Issue 1 or 12 , 2012

\section{Included studies}

Forty-four trials in which 17,401 participants had been randomised were included in this review. Twenty-three trials included RRMS (9096 participants, 52\%), 18 trials included progressive MS (7726, 44\%), and three trials included both RRMS and progressive MS (579, 3\%). The table Characteristics of included studies provides details on the characteristics of the included studies. The duration of the trials ranged from six to 36 months with the median duration being 24 months. The findings presented in this review originated mostly from trials on the IFN $\beta$ family, glatiramer acetate, and natalizumab that overall contributed outcome data for 12,275 patients $(71 \%$ ) included in 33 trials (Table 1). Eleven Cochrane reviews of active treatments versus placebo were included: IFNß for RRMS (Rice 2001), SPMS (La Mantia 2012)

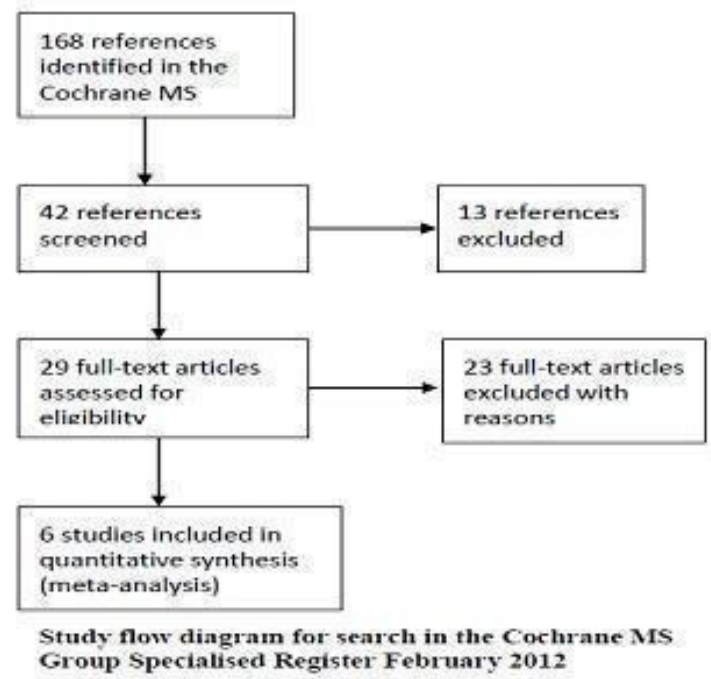

or PPMS (Rojas 2010); glatiramer acetate (La Mantia 2010); natalizumab (Pucci 2011); mitoxantrone (Martinelli 2005); methotrexate (Gray 2004); cyclophosphamide (La Mantia 2007); azathioprine (Casetta 2007); intravenous immunoglobulins (Gray 2003), and corticosteroids for long-term treatment (Ciccone 2008). Thirty-eight studies were included from the Cochrane reviews (Achiron 1998; AFFIRM 2006; Andersen 2004; Bornstein 1987; Bornstein 1991; BPSM 1995; British and Dutch 1988; CCMSSG 1991; Comi 2001; Edan 1997; Ellison 1989; European Study Group 1998; Fazekas 1997; Fazekas 2008; Ghezzi 1989; Goodkin 1991; Goodkin 1995; Hartung 2002; Hommes 2004; IFNB MS Group 1993; IMPACT 2002; Johnson 1995; Knobler 1993; Leary 2003; Lewanska 2002; Likosky 1991; Milanese 1993; Millefiorini 1997; Miller 1961; Montalban 2009; MSCRG 1996; NASP 2004; OWIMS 1999; Pohlau 2007; PRISMS 1998; SENTINEL 2006; 
SPECTRIMS 2001; Wolinsky 2007). The two arms of calcium aspirin and placebo in the Miller (Miller 1961) study were grouped as a single placebo arm by summing the number of events and the sample size.

Six trials of treatments directly compared to each other (BEYOND 2009; Etemadifar 2006; EVIDENCE 2007; INCOMIN 2002; Koch-Henriksen 2006; REGARD 2008) were retrieved by searching the Cochrane Multiple Sclerosis Review Group Specialised Register.

\section{Excluded studies}

Eight studies were excluded from the Cochrane reviews: two trials of IFN $\alpha$ (Durelli 1994; Myhr 1999); one because active treatment with natalizumab was confounded by glatiramer acetate (GLANCE 2009); one of oral glatiramer acetate (Filippi 2006); one of mitoxantrone in which the inclusion criteria were not described (Van de Wyngaert 2001); two trials because treatment with cyclophosphamide was confounded by other treatments (Hauser 1983; Wender 1988); and a dose comparison trial of long-term corticosteroids without a control group (Zivadinov 2001). In one study (CCMSSG 1991) one arm with combined cyclophosphamide, plasmapheresis, and prednisone was excluded. Another 23 studies were excluded from the 29 full-text articles identified through the Cochrane MS Review Group Specialised Register (see Characteristics of excluded studies).

\section{Risk of bias in included studies}

The RoB of the included studies is summarized (Figure 2; Figure 3). Considering our predefined criteria (allocation concealment, blinding of outcome assessment, and complete outcome data) to assess RoB overall for a study, five out of 44 (11\%) trials (Achiron 1998; AFFIRM 2006; British and Dutch 1988; Leary 2003; PRISMS 1998) were judged at low RoB, 21 (48\%) (Bornstein 1991; CCMSSG 1991; Comi 2001; Ellison 1989; Etemadifar 2006; EVIDENCE 2007; Fazekas 2008; Goodkin 1991; Hartung 2002; Hommes 2004; IFNB MS Group 1993; Johnson 1995; Knobler 1993; Lewanska 2002; Likosky 1991; Montalban 2009; Pohlau 2007; REGARD 2008; SENTINEL 2006; SPECTRIMS 2001; Wolinsky 2007) were evaluated at moderate RoB, and 18 (41\%) (Andersen 2004; BEYOND 2009; Bornstein 1987; BPSM 1995; Edan 1997; European Study Group 1998; Fazekas 1997; Ghezzi 1989; Goodkin 1995; IMPACT 2002; INCOMIN 2002; Koch-Henriksen 2006; Milanese 1993; Millefiorini 1997; Miller 1961; MSCRG 1996; NASP 2004; OWIMS 1999) were judged at high RoB.

Figure 2. Risk of bias graph: review authors' judgements about each risk of bias item presented as percentages across all included studies.

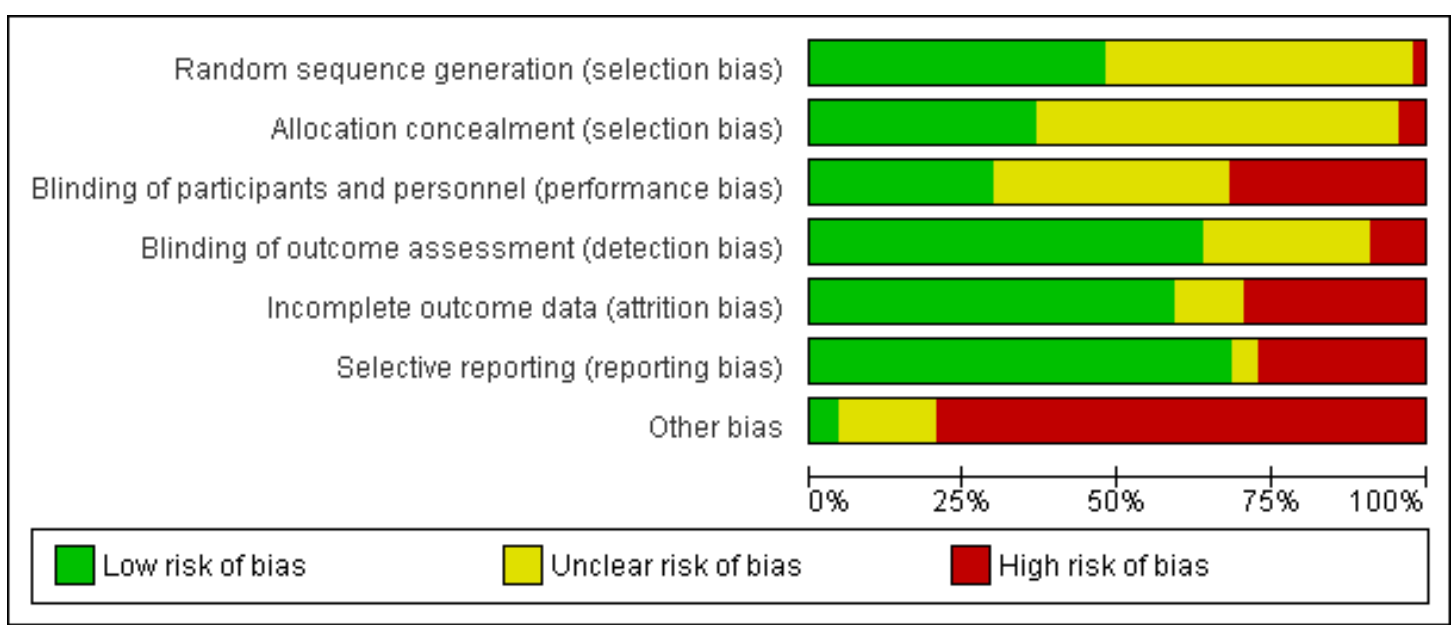

Immunomodulators and immunosuppressants for multiple sclerosis: a network meta-analysis (Review) 
Figure 3. Risk of bias summary: review authors' judgements about each risk of bias item for each included study.

\begin{tabular}{|c|c|c|c|c|c|c|c|}
\hline & 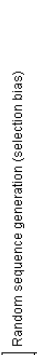 & 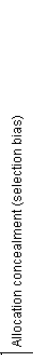 & 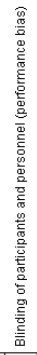 & 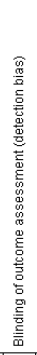 & 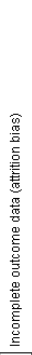 & 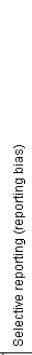 & 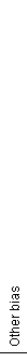 \\
\hline Achiron 1998 & $?$ & 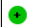 & (†) & (-) & ( & $\odot$ & $\theta$ \\
\hline AFFIRM 2006 & († & ๑ & ๑ & ๑ & ๑ & O & $\theta$ \\
\hline Andersen 2004 & $?$ & $?$ & $?$ & $?$ & e & $\odot$ & 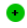 \\
\hline BEYOND 2009 & • & ๑) & - & (†) & (2) & ๑ & $\theta$ \\
\hline Bornstein 1987 & - & (2) & (?) & (†) & 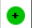 & ๑ & $\theta$ \\
\hline Bornstein 1991 & ๑ & $?$ & $?$ & ๑ & (- & ๑ & $\theta$ \\
\hline BPSM 1995 & ? & ๑) & $?$ & $?$ & ○ & (2) & ○ \\
\hline British and Dutch 1988 & (†) & $\odot$ & (๑) & ๑ & (๑) & $\theta$ & $\theta$ \\
\hline CCMSSG 1991 & $?$ & $?$ & ○ & (-) & (-) & (๑) & $\theta$ \\
\hline Comi 2001 & (•) & $?$ & $?$ & $?$ & ( & (ө & ( \\
\hline Edan 1997 & $?$ & $\odot$ & $\theta$ & - & ๑ & $\odot$ & $\theta$ \\
\hline Ellison 1989 & $?$ & $?$ & ๑ & ๑ & ๑ & ๑ & $\theta$ \\
\hline Etemadifar 2006 & $?$ & $?$ & - & (-) & (†) & ○ & $?$ \\
\hline European Study Group 1998 & ๑ & 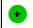 & $?$ & $?$ & - & ๑ & $\theta$ \\
\hline EVIDENCE 2007 & • & $?$ & ○ & (†) & ๑ & (ө & $\theta$ \\
\hline Fazekas 1997 & (†) & $\odot$ & - & ๑ & ○ & 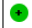 & ? \\
\hline Fazekas 2008 & (๑) & ๑) & ? & ? & $?$ & $\theta$ & $\theta$ \\
\hline Ghezi 1989 & $?$ & $?$ & ○ & ๑ & - & $\odot$ & $?$ \\
\hline Goodkin 1991 & (•) & $?$ & ๑ & ๑ & (†) & ๑ & $?$ \\
\hline Goodkin 1995 & $?$ & (- & $?$ & ๑ & ( & († & $\theta$ \\
\hline Hartung 2002 & (†) & $?$ & - & ๑ & ๑ & († & $\theta$ \\
\hline Hommes 2004 & $?$ & $?$ & $\odot$ & $\odot$ & $\odot$ & ๑ & $\theta$ \\
\hline IFNB MS Group 1993 & $?$ & $?$ & (- & (-) & $?$ & ๑ & ○ \\
\hline IMPACT 2002 & ? & $?$ & ? & $?$ & - & († & ○ \\
\hline INCOMIN 2002 & ๑) & (†) & - & ○ & (†) & $\odot$ & $\odot$ \\
\hline Johnson 1995 & ? & $?$ & $?$ & $?$ & (†) & († & (9) \\
\hline Knobler 1993 & $?$ & $?$ & (-) & ๑) & $?$ & (ө & $?$ \\
\hline Koch-Henriksen 2006 & $?$ & (†) & - & - & - & ○ & $\theta$ \\
\hline Leary 2003 & $?$ & (• & $?$ & (•) & (• & $\theta$ & $\theta$ \\
\hline Lewanska 2002 & (†) & $?$ & ? & ? & (†) & $\theta$ & $\theta$ \\
\hline Likosky 1991 & $?$ & $?$ & $?$ & (-) & (-) & (†) & $?$ \\
\hline Milanese 1993 & ? & $?$ & ? & ๑) & e & † & $\theta$ \\
\hline Millefiorini 1997 & ? & 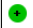 & అ & - & $\oplus$ & († & $\theta$ \\
\hline Miller 1961 & $?$ & $?$ & $?$ & $?$ & - & (†) & $?$ \\
\hline Montalban 2009 & (๑) & $?$ & ( & (†) & ๑ & († & $\theta$ \\
\hline MSCRG 1996 & $?$ & $?$ & ( & ๑ & - & † & $\theta$ \\
\hline NASP 2004 & (-) & (†) & (†) & ๑ & - & ? & $\theta$ \\
\hline OWIMS 1999 & ๑ & $?$ & ๑ & (•) & - & $\theta$ & $\theta$ \\
\hline Pohlau 2007 & (-) & $?$ & $?$ & $?$ & ? & $\odot$ & $\theta$ \\
\hline PRISMS 1998 & (๑) & ๑ & ๑) & • & (•) & ๑ & (อ \\
\hline REGARD 2008 & ๑ & $?$ & ○ & • & (๑) & ๑ & $\theta$ \\
\hline SENTINEL 2006 & (•) & † & (†) & $?$ & ( & † & $\theta$ \\
\hline SPECTRIMS 2001 & (๑) & $?$ & $?$ & ๑) & (๑) & ๑ & ○ \\
\hline Wolinsky 2007 & $?$ & $?$ & ? & $?$ & $?$ & ? & $\theta$ \\
\hline
\end{tabular}




\section{Allocation}

Sixteen of 44 trials $(36 \%)$ reported adequate methods for allocation concealment (low risk). Twenty-six trials (59\%) did not provide enough information to assess allocation concealment (unclear). Two trials (Bornstein 1987; Goodkin 1995) used an unconcealed procedure (high risk).

\section{Blinding}

Twenty-eight of 44 trials (64\%) reported adequate methods for blinding of outcome assessment (low risk). Twelve trials (27\%) did not provide enough information to assess it (unclear). This bias was judged at 'high risk' for four open label trials (Edan 1997; INCOMIN 2002; Koch-Henriksen 2006; Millefiorini 1997). We suspected that most participants and treating physicians had become aware of the treatment they were receiving during the course of the trial because all the agents included in this review have welldocumented side effects, for example injection-site reactions and influenza-like symptoms after IFNß injection.

\section{Incomplete outcome data}

Twenty-six of 44 (59\%) included studies were judged to meet this criterion because missing outcome data were less than $15 \%$ and were balanced in numbers across intervention groups with similar reasons for missing data across groups. In 13 (29\%) trials (Andersen 2004; BEYOND 2009; BPSM 1995; European Study Group 1998; Fazekas 1997; Ghezzi 1989; IMPACT 2002; KochHenriksen 2006; Milanese 1993; Miller 1961; MSCRG 1996; NASP 2004; OWIMS 1999) more than $15 \%$ of participants were lost to follow-up, or incomplete outcome data were not balanced in numbers or the reasons across groups (high risk). In five studies insufficient information was provided (unclear).

\section{Selective reporting}

Just half the studies ( 22 of 44; 50\%) reported outcomes of interest at two years' follow-up, and only eight (18\%) (Andersen 2004; British and Dutch 1988; CCMSSG 1991; Ellison 1989; European Study Group 1998; Milanese 1993; NASP 2004; SPECTRIMS 2001) reported outcomes at three years. One or more outcomes of interest were not reported or were presented incompletely in 12 studies (27\%) (AFFIRM 2006; BPSM 1995; British and Dutch 1988; Comi 2001; Etemadifar 2006; EVIDENCE 2007; Fazekas 2008; Knobler 1993; Koch-Henriksen 2006; Leary 2003; Lewanska 2002; OWIMS 1999) that were considered at high risk of reporting bias.

\section{Other potential sources of bias}

Sequence generation : 22 trials (50\%) did not provide enough information to assess sequence generation (unclear), and 21 (48\%) reported adequate methods (low risk). One of the trials (Bornstein 1987) used a sequence generated by alternation and was assigned 'high risk'.

Other bias : 24 (54.5\%) of 44 studies used an inadequate definition of sustained disability progression (confirmed at three months' follow-up) and 31 (70.5\%) were pharmaceutical industry-funded studies.

Method of adverse event (AEs) monitoring (Table 2): in 20 (45\%) trials, AEs were actively monitored and the RoB was judged to be low. Nineteen trials (43\%) reported insufficient information about the method of AEs monitoring so that it was uncertain whether or not AEs were monitored appropriately. RoB was judged to be unclear in these studies. Spontaneous reporting of AEs as they occurred was reported in four studies (Bornstein 1987; Bornstein 1991; EVIDENCE 2007; Goodkin 1991); one study (Etemadifar 2006) was lacking in safety assessment. These five trials (16\%) were judged at high RoB.

Serious adverse event (SAEs) defi nition and reporting: neither the definitions nor methods of quantification were specified for most of the included studies. In 23 (52\%) trials SAEs were not reported and the RoB was judged to be high. In 20 (45\%) trials SAEs were reported but insufficient information on their de fi nition was given and we judged the RoB to be unclear. Only one study (BEYOND 2009) provided a defi nition of SAEs and the RoB was judged to be low.

\section{Effects of interventions}

See: Summary of findings for the main comparison Summary of findings table

\section{Efficacy}

\subsection{Pairwise meta-analysis (direct comparisons)}

Summary of findings for the main comparison provides a summary of the risk estimates for each major outcome and the grading of the evidence.

\section{Recurrence of relapses over 12 months}

See: Summary of findings for the main comparison; Analysis 1.1; Analysis 1.2; Analysis 1.3

a) Treatments compared to placebo: 17 studies with 3581 participants $(21 \%$ of those included in this review) were available. 
Data for RRMS was provided in 13 out of 17 trials, with 2770 (77\%) participants (Achiron 1998; AFFIRM 2006; Bornstein 1987; BPSM 1995; Comi 2001; Fazekas 2008; Goodkin 1991; Knobler 1993; Lewanska 2002, Millefiorini 1997; MSCRG 1996; OWIMS 1999; PRISMS 1998). Nine agents (IFNß-1b, IFNß1a (Avonex, Rebif), glatiramer acetate, natalizumab, azathioprine, mitoxantrone, intravenous immunoglobulins, and long-term corticosteroids) were assessed.

Data for progressive MS was provided in only two trials. One assessed azathioprine (Ellison 1989) in 99 participants and the other (Hommes 2004) evaluated intravenous immunoglobulins in 318 participants. Two studies of azathioprine (British and Dutch 1988; Milanese 1993) presented grouped data as RRMS or progressive MS (394 participants, 11\%).

The following results for participants with RRMS were found.

- Natalizumab reduced the odds (OR $0.38,95 \%$ CI 0.28 to 0.51 ), a $62 \%$ reduction in the number of participants who had relapses compared with placebo.

- Mitoxantrone probably reduced the odds (OR 0.14, 95\% CI 0.04 to 0.48 ), a $86 \%$ reduction in the number of participants who had relapses compared with placebo, but the quality of evidence for this treatment was moderate.

- Azathioprine reduced slightly the odds (OR 0.63, 95\% CI 0.44 to 0.89 ) when data across all trials that studied this agent were pooled, but meaningful odds estimates, specific for RRMS and progressive MS, were uncertain since there was only one small study for each of the two phenotypes (Ellison 1989; Goodkin 1991). The two studies (British and Dutch 1988; Milanese 1993) that included grouped data for participants with RRMS or progressive MS were excluded from the analysis.

- IFNß-1b (Betaseron), IFNß-1a (Avonex), IFNß-1a (Rebif) and long-term corticosteroids might have slightly reduced the odds (OR $0.60,95 \%$ CI 0.10 to 3.49; OR 0.72 , $95 \%$ CI 0.45 to 1.14; OR $0.66,95 \%$ CI 0.25 to 1.78 ; OR $0.46,95 \%$ CI 0.12 to 1.84 ) of the participants with RRMS, but the quality of evidence for all these treatments was low.

- There was uncertainty regarding the effect of glatiramer acetate and intravenous immunoglobulins for RRMS since the quality of the evidence for these two treatments was very low.

The study of intravenous immunoglobulins (Hommes 2004) reporting relapse outcome in progressive MS stated that the numbers of participants who had experienced relapses over 12 months were not statistically significantly different from those observed in the placebo group.

b) Treatments compared to each other: three studies with 2036 RRMS participants ( $14 \%$ of those included in this review) compared natalizumab with IFNß-1a (Avonex) (SENTINEL 20066), IFNß-1a (Avonex) with IFNß-1b (Betaseron) (INCOMIN 2002), and IFNß-1a (Rebif) versus IFNß-1a (Avonex) (EVIDENCE 2007).

- Natalizumab reduced the odds compared with IFNß-1a (Avonex) (OR 0.40, 95\% CI 0.32 to 0.51 ), a $60 \%$ reduction in the number of RRMS participants who had relapses over 12 months.

- IFNß-1a (Rebif) also might have decreased the odds compared to IFNß-1a (Avonex) (OR 0.79, 95\% CI 0.58 to 1.07).

- INCOMIN 2002 was judged to have very low quality evidence to allow a meaningful comparison between IFNß-1b (Betaseron) and IFNß-1a (Avonex).

Mitoxantrone might have decreased the odds of the participants with progressive MS, compared to long-term corticosteroids (OR $0.25,95 \%$ CI 0.07 to 0.90 ) but the CI around the estimate of treatment effect was very wide (Edan 1997).

\section{Recurrence of relapses over 24 months}

See: Summary of findings for the main comparison; Analysis 2.1; Analysis 2.2; Analysis 2.3

a) Treatments compared to placebo: 20 studies with 4695 participants ( $27 \%$ of those included in this review) were available.

Eleven trials in RRMS (2812 participants, 60\% of those compared to placebo) (Achiron 1998; AFFIRM 2006; Bornstein 1987; BPSM 1995; Fazekas 1997; Goodkin 1991; IFNB MS Group 1993; Johnson 1995; Millefiorini 1997; MSCRG 1996; PRISMS 1998) assessed 10 agents, IFNß-1b (Betaseron), IFNß-1a (Avonex), IFNß-1a (Rebif), glatiramer acetate, natalizumab, azathioprine, methotrexate, mitoxantrone, intravenous immunoglobulins, and long-term corticosteroids.

Six trials in progressive MS (1304 participants, 28\% of those compared to placebo) (Ellison 1989; Goodkin 1995; Hartung 2002; Hommes 2004; IMPACT 2002; Pohlau 2007) evaluated five agents, IFNß-1a (Avonex), azathioprine, methotrexate, mitoxantrone, and intravenous immunoglobulins. Three trials (British and Dutch 1988; Ghezzi 1989; Milanese 1993) assessed azathioprine in 579 (12\%) participants with RRMS and progressive MS combined.

The following results for participants with RRMS were found.

- Both natalizumab and IFNß-1a (Rebif) reduced the odds (OR 0.32 , $95 \%$ CI 0.24 to 0.43 ; OR 0.45 , $95 \%$ CI 0.28 to 0.71 , respectively), a $68 \%$ and $55 \%$ reduction in the number of participants who had relapses over 24 months compared with placebo.

- IFNß-1b (Betaseron) and mitoxantrone probably decreased the odds (OR 0.55, 95\% CI 0.31 to 0.99 ; OR 0.15, 95\% CI 0.04 to 0.54 , respectively) compared with placebo, but the quality of evidence for these treatments was moderate.

- Azathioprine reduced the odds (OR 0.64, 95\% CI 0.44 to $0.94)$ when all the included trials of azathioprine were aggregated, but this treatment was not statistically significantly different from control when data for RRMS and progressive MS were analysed separately. Azathioprine might have decreased slightly the odds of the participants with RRMS (OR 0.36, 95\% CI 0.11 to 1.21 ). 
- For the other five treatments (IFNß-1a (Avonex), glatiramer acetate, methotrexate, intravenous immunoglobulins, and longterm corticosteroids), the numbers of RRMS participants experiencing new relapses were not statistically significantly different from the numbers in the placebo groups.

IFNß-1a (Avonex), methotrexate, azathioprine, mitoxantrone, and intravenous immunoglobulins were not effective for progressive MS.

b) Treatments compared to each other: four trials in RRMS (4427, 25\% of those included in this review) provided direct comparisons between treatments, natalizumab versus IFNß-1a (Avonex) (SENTINEL 2006), IFNß-1b (Betaseron) versus IFNß1a (Avonex) (INCOMIN 2002), IFNß-1b (Betaseron) versus glatiramer acetate (BEYOND 2009), and glatiramer acetate versus IFNß-1a (Rebif) (REGARD 2008). One three-arm trial (Etemadifar 2006) compared IFNß-1b (Betaseron), IFNß-1a (Avonex), and IFNß-1a (Rebif).

- Natalizumab, IFNß-1b (Betaseron), and IFNß-1a (Rebif) were significantly more effective than IFNß-1a (Avonex) (OR $0.28,95 \%$ CI 0.22 to 0.36 ; OR $0.44,95 \%$ CI 0.26 to 0.75 ; OR $0.19,95 \%$ CI 0.06 to 0.60 , respectively) for RRMS participants.

- The quality of the evidence was too low to allow meaningful comparisons of glatiramer acetate with IFNß-1b (Betaseron) or IFNß-1a (Rebif).

\section{Relapses over 36 months}

See: Summary of findings for the main comparison; Analysis 3.1 Information on this outcome was not available for RRMS. Four trials in 2127 progressive MS participants (14\% of those included in this review) compared IFNß-1b (Betaseron) (European Study Group 1998; NASP 2004), IFNß-1a (Rebif) (Andersen 2004), azathioprine (Ellison 1989) versus placebo. Two studies (British and Dutch 1988; Milanese 1993) assessed azathioprine in 394 participants with RRMS and progressive MS combined.

- Azathioprine (OR 0.45, 95\% CI 0.27 to 0.76 ) and IFNß$1 \mathrm{~b}$ (Betaseron) decreased slightly (OR $0.71,95 \%$ CI 0.56 to $0.90)$ the odds of experiencing new relapses over three years in progressive MS, compared with placebo.

- IFNß-1a (Rebif) may have resulted in little or no difference in this outcome compared to participants with progressive MS who took placebo, but the quality of evidence was low so our confidence in this result was low.

\section{Disability progression over 24 months}

See: Summary of findings for the main comparison; Analysis 4.1; Analysis 4.2; Analysis 4.3

a) Treatments compared to placebo: 24 studies with 6160 participants ( $41 \%$ of those included in this review) were available.

Ten studies in RRMS (2776 participants, 45\%) (Achiron 1998; AFFIRM 2006; Bornstein 1987; Fazekas 1997; Goodkin 1991;
IFNB MS Group 1993; Johnson 1995; Millefiorini 1997; MSCRG 1996; PRISMS 1998) assessed eight agents, IFNß-1b (Betaseron), IFNß-1a (Avonex), IFNß-1a (Rebif), glatiramer acetate, natalizumab, azathioprine, mitoxantrone, and intravenous immunoglobulins versus placebo.

Twelve studies in progressive MS (3159 participants, 51\%) (Bornstein 1991; Goodkin 1995; Hartung 2002; Hommes 2004; IMPACT 2002; Leary 2003; Likosky 1991; Miller 1961; Montalban 2009; Pohlau 2007; SPECTRIMS 2001; Wolinsky 2007) evaluated nine agents, IFNß-1b (Betaseron), IFNß-1a (Avonex), IFNß-1a (Rebif), glatiramer acetate, methotrexate, mitoxantrone, cyclophosphamide, intravenous immunoglobulins, and long-term corticosteroids. Two studies of azathioprine (Ghezzi 1989; Milanese 1993) reported the outcome in 225 (4\%) RRMS and progressive MS participants combined.

The following results for participants with RRMS were found.

- Natalizumab and IFNß-1a (Rebif) probably reduced the odds (OR 0.56, 95\% CI 0.42 to 0.74 ; OR 0.65 , 95\% CI 0.45 to 0.93 , respectively) by $44 \%$ and $35 \%$ compared with placebo.

- Mitoxantrone might have reduced the odds (OR 0.13, 95\% CI 0.03 to 0.70 ) but the $\mathrm{CI}$ around the estimate of treatment effect was very wide.

- None of the other treatments were statistically significantly different from placebo in terms of the number of RRMS participants experiencing disability progression over 24 months.

There was no effect of all these treatments for progressive MS. b) Treatments compared to each other: direct comparisons of active agents were available from five two-arm studies with 4668 RRMS participants (31\% of those included in this review) comparing natalizumab versus IFNß-1a (Avonex) (SENTINEL 2006), IFNß1b (Betaseron) versus IFNß-1a (Avonex) (INCOMIN 2002), IFNß-1b (Betaseron) versus IFNß-1a (Rebif) (Koch-Henriksen 2006), glatiramer acetate versus IFNß-1b (Betaseron) (BEYOND 2009), and glatiramer acetate versus IFNß-1a (Rebif) (REGARD 2008).

- Natalizumab and IFNß-1b (Betaseron) were significantly more effective (OR 0.62, 95\% CI 0.49 to 0.78 ; OR 0.35 , $95 \%$ CI 0.17 to 0.70 , respectively) than IFNß-1a (Avonex) for RRMS.

- The quality of the evidence was too low to allow meaningful comparisons of IFNß-1b (Betaseron) with IFNß-1a (Rebif), and glatiramer acetate with IFNß-1b (Betaseron) or with IFNß-1a (Rebif).

One small trial (Edan 1997) comparing mitoxantrone with longterm corticosteroids in progressive MS patients did not find a difference between the two treatments.

\section{Disability progression over 36 months}

See: Summary of findings for the main comparison; Analysis 5.1 This outcome was not reported in trials for RRMS. Data for this outcome were available from seven two-arm studies in 2896 
progressive MS participants $(19 \%$ of those included in this overview). The trials compared IFNß-1b (Betaseron) (European Study Group 1998; NASP 2004), IFNß-1a (Rebif) (Andersen 2004; SPECTRIMS 2001), azathioprine (Ellison 1989; Milanese 1993), cyclophosphamide (CCMSSG 1991) versus placebo.

Although results for these four agents did not reach statistical significance, azathioprine was associated with the least number of participants experiencing disability progression (OR 0.47, 95\% CI 0.19 to 1.17 ) and cyclophosphamide was associated with the most number of participants who had disability progression in comparison to placebo (OR 1.60, 95\% CI 0.76 to 3.39). However, we judged the quality of these studies as very low, so our confidence in these results was very low.

\subsection{Network meta-analysis (combination of direct and indirect comparisons)}

Figure 4 shows the networks of the treatments for recurrence of relapses and disability progression at each time point, and acceptability of treatments over 24 months of follow-up. Each line links treatments directly compared in trials. The thickness of the line is proportional to the number of comparisons included in the network; the width of the circle is proportional to the number of studies involving the specific treatment.

Figure 4. Networks of the treatments for recurrence of relapses and disability progression at each time point and acceptability of treatments over 24 months of follow-up

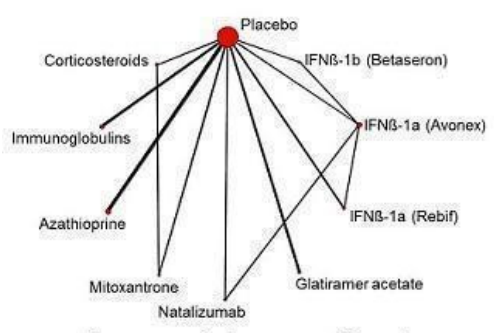

Recurrence of relapses over 12 months

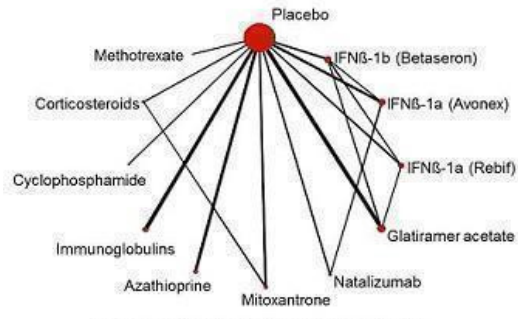

Disability progression over 24 months

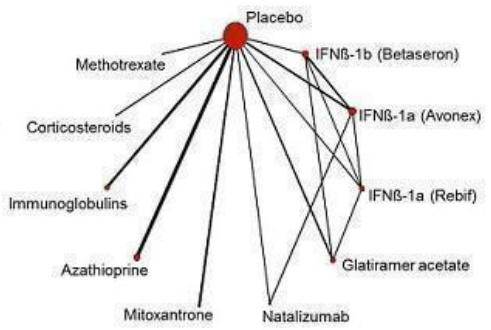

Mitoxantrone Natalizumab

Recurrence of relapses over 24 months

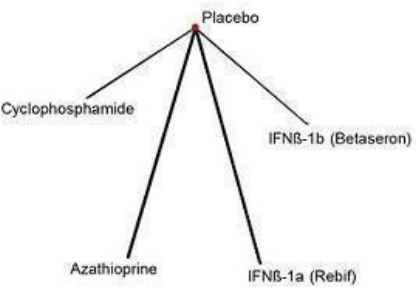

Disability progression over 36 months

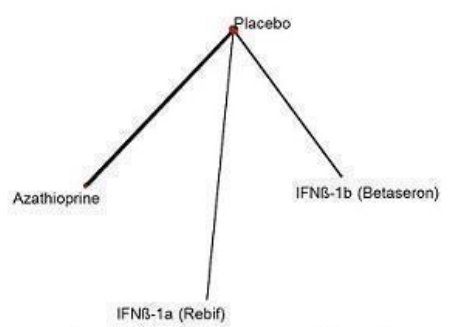

Recurrence of relapses over 36 months

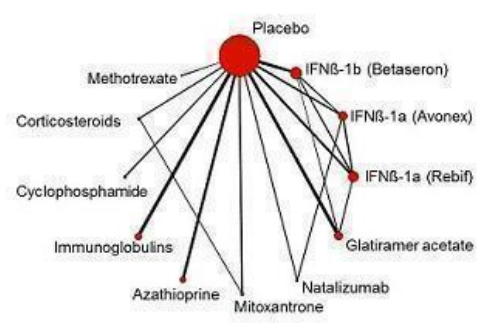

Acceptability over 24 months
There was no statistical or clinical indication that the assumption of consistency was inappropriate. No loop was found to be statistically inconsistent (Figure 5), the DIC of the consistency model was always lower compared to the inconsistency models, and the pairwise meta-analyses were not dissimilar in trial methods and populations. Table 3 reports model fit and parsimony measures for all the primary outcomes along with the DIC values for the consistency and inconsistency models.

Summary ORs (posterior values and their 95\% credible intervals
$(\mathrm{CrI}))$ of all active interventions versus placebo and SUCRA values expressed as a percentage are reported in Table 4 for relapses over 12, 24, and 36 months; in Table 5 for disability progression over 24 and 36 months; in Table 6 for relapses over 12 and 24 months and progression over 24 months in the subgroup of participants with RRMS. In the subgroup of progressive MS, only pairwise meta-analyses were done as the number of studies was small for each outcome and time point. 
Figure 5. Evaluation of consistency within first order closed loops for recurrence of relapses and disability progression at each time point. Difference in log odds ratios between indirect and direct evidence is reported on x-axis.

\section{Estimates with 958 confidence intervals}
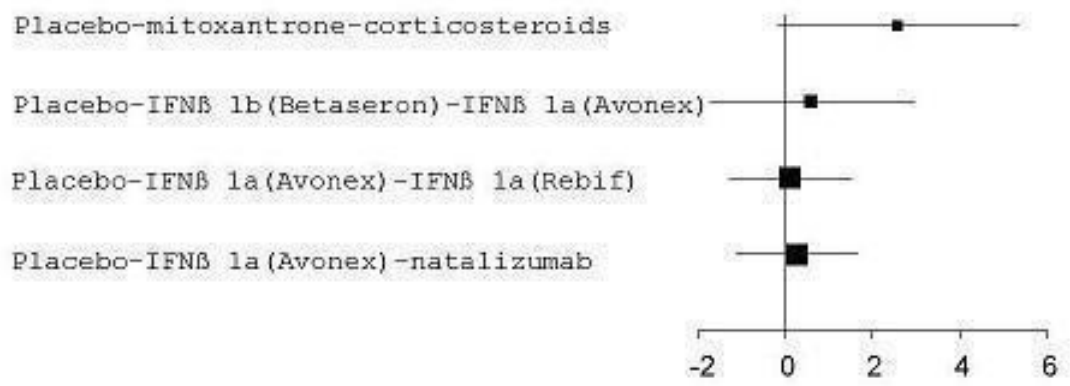

Recurrence of relapses over 12 months

\section{Estimates with 958 confidence intervals}

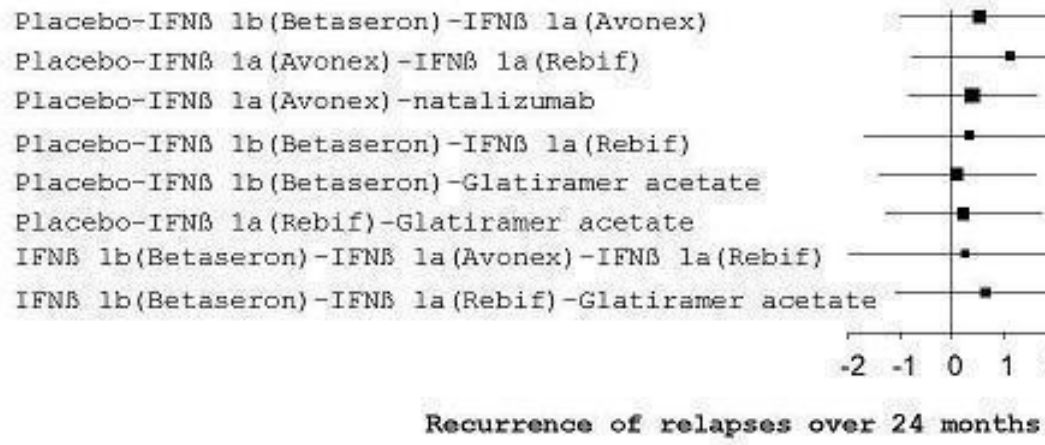

Recurrence of relapses over 24 months

Estimates with 958 confidence intervals

Placebo-mitoxantrone-corticosteroids

P1acebo-IFNB 1b (Betaseron)-IFNB 1a (Avonex)

Placebo-IFNB la (Avonex)-ratalizumab

P1acebo-IFNB 1b(Betaseron)-IFNB la (Rebif)

Placebo-IFNB lb(Betaseron)-glatiramer acetate

Placebo-IFNß la (Rebif)-glatiramer acetate

IFNB 1b(Betaseron)-IFNB 1a (Rebif)-glatiramer acetate

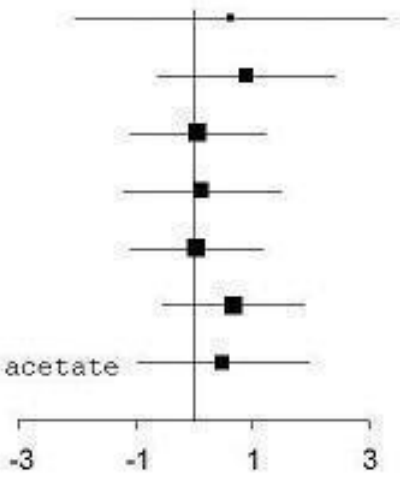

Disability progression over 24 months 


\section{Relapses over 12, 24, and 36 months}

See: Table 4

a) Relapses over 12 months were provided in 20 studies ( Achiron 1998; AFFIRM 2006; Bornstein 1987; BPSM 1995; British and Dutch 1988; Comi 2001; Edan 1997; Ellison 1989; EVIDENCE 2007; Fazekas 2008; Goodkin 1991; Hommes 2004; INCOMIN 2002; Knobler 1993; Lewanska 2002; Milanese 1993; Millefiorini 1997; MSCRG 1996; OWIMS 1999; PRISMS 1998; SENTINEL 2006) and 5628 participants with MS (37.5\% of those included in this review). Mitoxantrone was the best drug (median OR versus placebo 0.12 , 95\% CrI 0.03 to 0.55 ; SUCRA $=95 \%$ ) followed by natalizumab (median OR versus placebo 0.35 , $95 \%$ CrI 0.12 to 1.06 ; SUCRA $=72 \%)$. The heterogeneity standard deviation $\tau$ was 0.60 (95\% CrI 0.22 to 1.18 ).

b) Relapses over 24 months were provided in 25 studies ( Achiron 1998; AFFIRM 2006; BEYOND 2009; Bornstein 1987; BPSM 1995; British and Dutch 1988; Ellison 1989; Etemadifar 2006; Fazekas 1997; Ghezzi 1989; Goodkin 1991; Goodkin 1995; Hartung 2002; Hommes 2004; IFNB MS Group 1993; IMPACT 2002; INCOMIN 2002; Johnson 1995; Milanese 1993; Millefiorini 1997; MSCRG 1996; Pohlau 2007; PRISMS 1998; REGARD 2008; SENTINEL 2006) and 9186 participants with MS (61\% of those included in this review). Different agents seemed to be significantly correlated to relapse at 24 months' follow-up. The most effective drug appeared to be natalizumab (median OR versus placebo $0.29,95 \%$ CrI 0.17 to 0.51 ; SUCRA = 92\%), followed by IFNß-1a (Rebif) (median OR versus placebo $0.44,95 \%$ CrI 0.24 to 0.70 ; SUCRA $=73 \%$ ), mitoxantrone (median OR versus placebo $0.43,95 \%$ CrI 0.20 to 0.87 ; SUCRA = $71 \%$ ), glatiramer acetate (median OR versus placebo $0.48,95 \%$ CrI 0.38 to 0.75 ; SUCRA $=66 \%$ ), IFNß-1b (Betaseron) (median OR versus placebo $0.48,95 \% \mathrm{CrI} 0.29$ to 0.78 ; SUCRA $=65 \%$ ). The heterogeneity standard deviation $\tau$ was 0.20 (95\% CrI 0.01 to 0.53 ).

c) Relapses over 36 months were available from six studies (Andersen 2004; British and Dutch 1988; Ellison 1989; European Study Group 1998; Milanese 1993; NASP 2004) (2521, 17\% of those included in this review) comparing each agent azathioprine, cyclophosphamide, IFNß-1b (Betaseron), IFNß-1a (Rebif) versus placebo. Only azathioprine appeared to be effective (mean OR $0.43,95 \%$ CrI 0.17 to 0.88 ; SUCRA $=94 \%$ ). The heterogeneity standard deviation $\tau$ was 0.30 (95\% CrI 0.02 to 1.27 ).

\section{Disability progression over 24 and 36 months}

See: Table 5

a) Disability progression over 24 months was available from 30 studies (Achiron 1998; AFFIRM 2006; BEYOND 2009;
Bornstein 1987; Bornstein 1991; Edan 1997; Fazekas 1997; Ghezzi 1989; Goodkin 1991; Goodkin 1995; Hartung 2002; Hommes 2004; IFNB MS Group 1993; IMPACT 2002; INCOMIN 2002; Johnson 1995; Koch-Henriksen 2006; Leary 2003; Likosky 1991; Milanese 1993; Millefiorini 1997; Miller 1961; Montalban 2009; MSCRG 1996; Pohlau 2007; PRISMS 1998; REGARD 2008; SENTINEL 2006; SPECTRIMS 2001; Wolinsky 2007) and 10,828 participants with MS (72\%\% of those included in this review). Mitoxantrone appeared to be the most effective agent at 24 months' follow-up (median OR versus placebo $0.42,95 \%$ CrI 0.20 to 0.87 ; SUCRA $=89 \%$ ). Natalizumab and glatiramer acetate showed a similar effect (median OR versus placebo $0.61,95 \% \mathrm{CrI} 0.41$ to $0.91 ; 0.67,95 \% \mathrm{CrI} 0.49$ to $0.88)$. The heterogeneity standard deviation was 0.20 (95\% CrI 0.03 to 0.38 ).

b) Disability progression over 36 months was available in seven trials with IFNß-1b (Betaseron) (European Study Group 1998; NASP 2004), IFNß-1a (Rebif) (Andersen 2004; SPECTRIMS 2001), azathioprine (Ellison 1989; Milanese 1993), and cyclophosphamide (CCMSSG 1991) compared to placebo. None of the four agents was effective in preventing progression at this time. The heterogeneity standard deviation $\tau$ was 0.39 (95\% CrI 0.05 to 1.33$)$.

\section{Subgroup and sensitivity analyses}

- Participants with RRMS (Table 6)

a) Relapses over 12 months were provided in 16 trials (4817 participants, $32 \%$ of those included in this review) (Achiron 1998; AFFIRM 2006; Bornstein 1987; BPSM 1995; Comi 2001; EVIDENCE 2007; Fazekas 2008; Goodkin 1991; INCOMIN 2002; Knobler 1993; Lewanska 2002; Millefiorini 1997; MSCRG 1996; OWIMS 1999; PRISMS 1998; SENTINEL 2006) and nine treatments, IFNß-1b (Betaseron), IFNß-1a (Avonex), IFNß1a (Rebif), glatiramer acetate, natalizumab, azathioprine, mitoxantrone, intravenous immunoglobulins, and long-term corticosteroids versus placebo. In the network meta-analysis there was no statistically significant effect of these treatments compared to the control groups.

b) Relapses at 24 months were provided in 16 trials (7269, $48 \%$ of those included in this review) (Achiron 1998; AFFIRM 2006; BEYOND 2009; Bornstein 1987; BPSM 1995; Etemadifar 2006; Fazekas 1997; Goodkin 1991; IFNB MS Group 1993; INCOMIN 2002; Johnson 1995; Millefiorini 1997; MSCRG 1996; PRISMS 1998; REGARD 2008; SENTINEL 2006) and nine treatments, IFNß-1b (Betaseron), IFNß-1a (Avonex), IFNß1a (Rebif), glatiramer acetate, natalizumab, mitoxantrone, azathioprine, intravenous immunoglobulins, long-term corticosteroids, and placebo. Mitoxantrone was the most effective agent 
with a median OR of 0.14 (95\% CrI 0.03 to 0.55 ; SUCRA = $92 \%$ ) followed by natalizumab (median OR $0.31,95 \%$ CrI 0.19 to 0.55 ; SUCRA $=75 \%$ ), intravenous immunoglobulins (median OR $0.34,95 \%$ CrI 0.13 to 0.69 ; SUCRA $=70 \%$ ), azathioprine (median OR 0.34, 95\% CrI 0.08 to 1.30; SUCRA = 65\%), IFNß1a (Rebif) (median OR 0.46, 95\% CrI 0.25 to 0.71 ; SUCRA = $53 \%$ ), IFNß-1b (Betaseron) (median OR 0.50, 95\% CrI 0.31 to 0.82 ; SUCRA $=45 \%$ ), and glatiramer acetate (median OR 0.50, $95 \%$ CrI 0.29 to 0.77 ; SUCRA $=46 \%)$. The heterogeneity standard deviation was 0.17 (95\% CrI 0.01 to 0.73 ).

c) Progression at 24 months was provided in 15 two-arm studies (7444 participants, $50 \%$ of those included in this review) (Achiron 1998; AFFIRM 2006; BEYOND 2009; Bornstein 1987; Fazekas
1997; Goodkin 1991; IFNB MS Group 1993; INCOMIN 2002; Johnson 1995; Koch-Henriksen 2006; Millefiorini 1997; MSCRG 1996; PRISMS 1998; REGARD 2008; SENTINEL 2006) and eight treatments, IFNß-1b (Betaseron), IFNß-1a (Avonex), IFNß-1a (Rebif), glatiramer acetate, natalizumab, mitoxantrone, azathioprine, intravenous immunoglobulins, and placebo. Mitoxantrone seemed to be the most effective agent in reducing the number of participants with disability progression at 24 months (median OR $0.11,95 \% \mathrm{CrI} 0.01$ to 0.65 ; SUCRA $=96 \%$ ), followed by glatiramer acetate (median OR 0.52, 95\% CrI 0.28 to 0.88 ; SUCRA $=70 \%$ ). The heterogeneity standard deviation was 0.29 (95\% CrI 0.03 to 0.80$)$.

- Dose effects (Figure 6)

Figure 6. Forest plot: disability progression over 24 months in MS of all types according to each agent-dose compared to placebo.

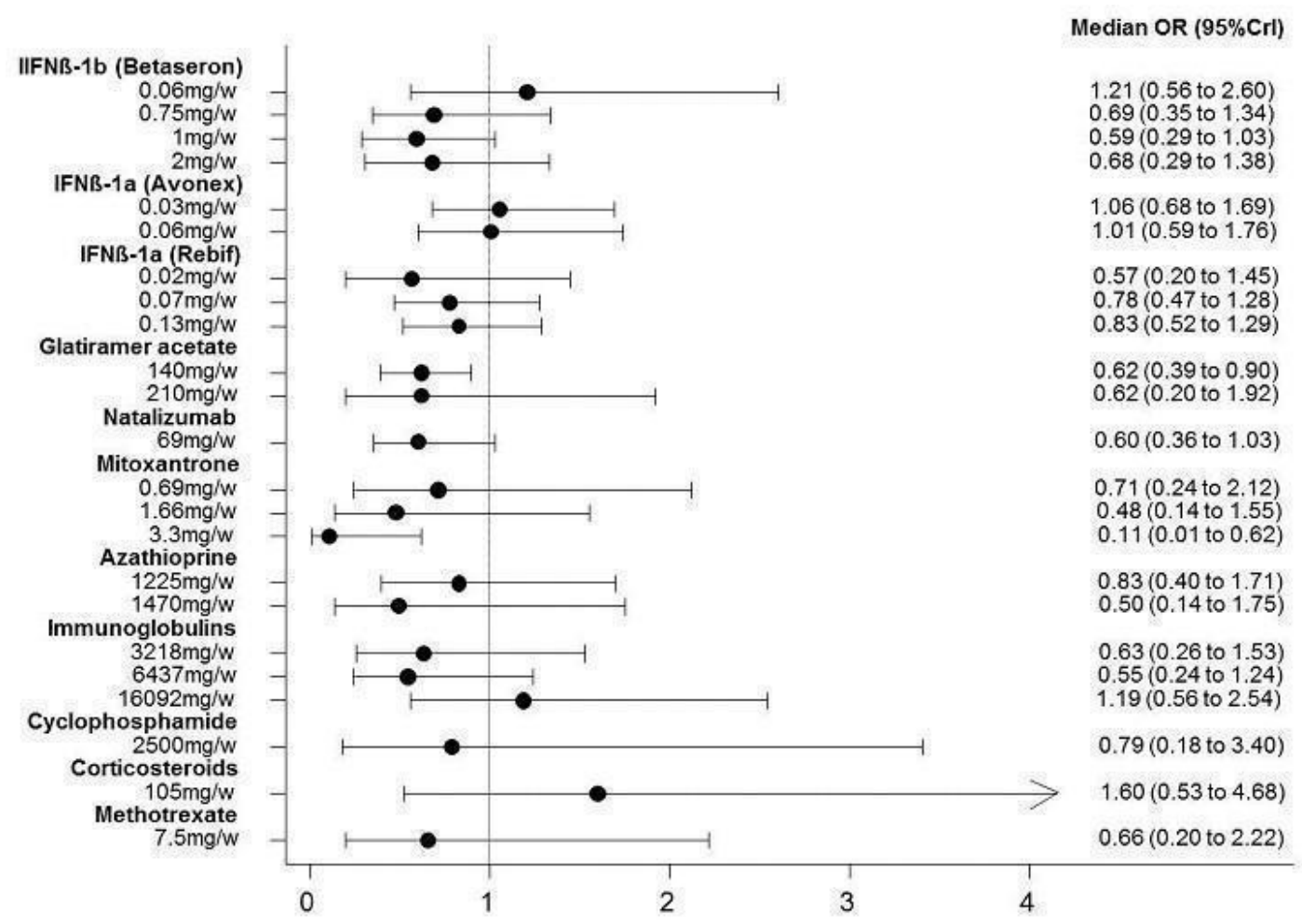

Thirty studies were available comparing 24 agent doses for progression at 24 months. When each dose was assumed to be a different treatment the DIC was 125 compared to 117 when each dose had a fixed agent-specific effect, indicating that the dose did not alter the agent's effectiveness much. The dose by week anal-

ysis suggested that mitoxantrone was the most effective drug in delaying disability progression at 24 months when administered intravenously at $12 \mathrm{mg} / \mathrm{m}^{2} /$ body surface area every three months (median OR 0.11, 95\% CrI 0.01 to 0.62; SUCRA = 91\%). Over- 
all the ranking of the agents was consistent with this result obtained when the dose-effects were ignored, as presented in Table 5. Exploration of models that assumed a monotonic or linear doseeffect association did not improve fit or parsimony and similar observations were made for the analysis of relapses at 24 months (Del Giovane 2013).

\section{- Priors for heterogeneity}

We re-analysed the primary efficacy outcomes using a uniform prior between 0 and 3 for standard deviation; no important changes were observed in the results.

\section{- Sponsoring}

Thirty-one out of 44 (70.5\%) studies were sponsored by pharmaceutical companies; eight studies (18\%) (Bornstein 1987; Bornstein 1991; BPSM 1995; Goodkin 1995; INCOMIN 2002; Lewanska 2002; Likosky 1991; Miller 1961) were supported by public institutions or had no funding; and five studies (11\%) (Edan 1997; Etemadifar 2006; Ghezzi 1989; Koch-Henriksen 2006; Millefiorini 1997) did not provide enough information to understand if any sponsor had a role in the trial (see Characteristics of included studies). As the number of studies and treatments evaluated in publicly sponsored studies were very small, we did not undertake a sensitivity analysis as planned.

\section{Acceptability of the interventions}

\section{See: Table 7}

The network meta-analysis showed that there was no difference among treatments in the number of participants who dropped out (withdrawals or lost to follow-up) due to adverse events throughout the studies, up to 24 months. The heterogeneity standard deviation was 0.16 (95\% CrI 0.01 to 0.46$)$. No sensitivity to prior for heterogeneity was observed.

\section{Secondary outcomes}

Results of pairwise meta-analyses are summarized below.

1. Participants with at least one AE: most of the trials reported only the number of events; the number of participants was reported rarely. Moreover, definitions and reporting of AEs were so different among the included studies that it was impossible to extract quantitative data (Table 2).

2. Serious adverse events ( $S A E s$ ): there was no statistically significant effect of the treatments compared to the placebo groups (Analysis 6.1). In one study (Hartung 2002) mitoxantrone $\left(12 \mathrm{mg} / \mathrm{m}^{2}\right)$ was associated with increased odds of participants who had SAEs compared with placebo (OR 2.58, 95\% CI 0.48 to 13.81); in another two trials with this agent (Edan 1997; Millefiorini 1997) no SAEs were reported. Trials of azathioprine reported the occurrence of AEs, although severity was not detailed. The number of deaths (related or unrelated to the agent) or number of participants who committed or attempted suicide were not significantly more frequent $(\mathrm{P}=0.91 ; \mathrm{P}=0.86)$ in the active treatment arms compared to placebo (data not shown).

3. Withdrawals due to AEs: overall, there was a statistically significant effect of the treatments as a group compared to placebo (OR $2.41,95 \%$ CI 1.92 to $3.03 ; \mathrm{P}=0.001$ ) (Analysis 6.2). Agents associated with significantly increased odds of participants who were withdrawn due to AEs compared with placebo were interferons (OR 3.08, 95\% CI 2.23 to 4.26; $\mathrm{P}<0.001$ ), glatiramer acetate (OR 3.48, 95\% CI 1.55 to $7.84 ; \mathrm{P}=0.003$ ), natalizumab (OR $1.36,95 \%$ CI 0.99 to $1.85 ; \mathrm{P}=0.06$ ), azathioprine (OR 6.35 , $95 \%$ CI 2.50 to $16.11 ; \mathrm{P}<0.001)$, and intravenous immunoglobulins (OR 1.99, 95\% CI 1.07 to 3.71; $\mathrm{P}=0.03$ ). No difference in withdrawals due to AEs was found for mitoxantrone, however only one study was included, which was likely to lead to typeII error. There were no significant differences in withdrawals in direct comparison trials of the interferons compared to each other or to glatiramer acetate (data not shown).

4. Serious infections: two cases of progressive multifocal leukoencephalopathy, one of which was fatal, were reported in natalizumab-treated participants (SENTINEL 2006). Overall, there was not a statistically significant effect of the treatments as a group compared with the placebo groups (data not showed).

5. Leukaemia, lymphoma, or any other type of cancer: no increased odds for active treatments compared with placebo were reported in the included trials (data not showed).

6. Other AEs are reported in the Cochrane reviews on interferons (La Mantia 2012; Rice 2001; Rojas 2010), glatiramer acetate (La Mantia 2010), natalizumab (Pucci 2011), azathioprine (Casetta 2007), mitoxantrone (Martinelli 2005), intravenous immunoglobulins (Gray 2003), cyclophosphamide (La Mantia 2007), methotrexate (Gray 2004), and long-term corticosteroids (Ciccone 2008).

\section{Reporting bias}

The funnel plots for recurrence of relapses and disability progression over 24 and 36 months and acceptability over 24 months are showed in Figure 7. For outcomes at 36 months there are not enough data to judge the reporting bias; for recurrence of relapses over 24 months there is an indication of small study effects where asymmetry in the plot is present due to 'missing' studies on the right side. For the other outcomes, the plots suggested that there was no association between the study size and its effect. 
Figure 7. 'Comparison-adjusted' funnel plots. In the horizontal axis the differences between the observed log-odds ratios of each active treatment versus placebo and their summary effect obtained from the pairwise meta-analysis are presented; in the vertical axis the standard errors of the log-odds ratios are presented. Differences on the left of null represent studies with estimates larger than the comparison-specific mean.

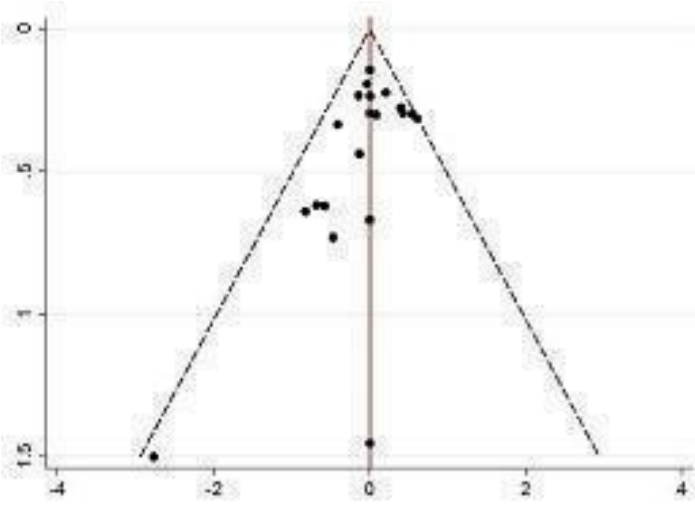

Recurrence of relapses over 24 months

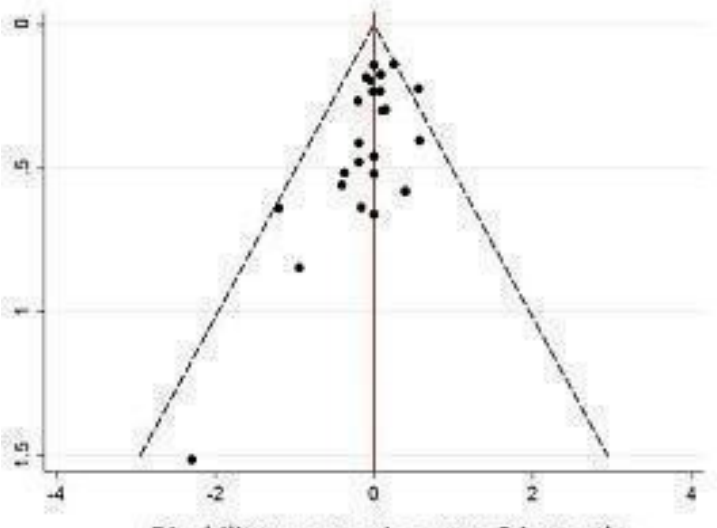

Disability progression over 24 months

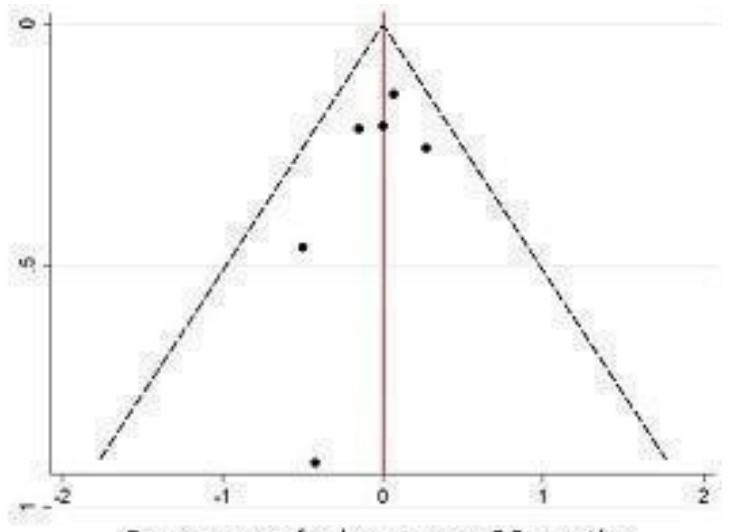

Recurrence of relapses over 36 months

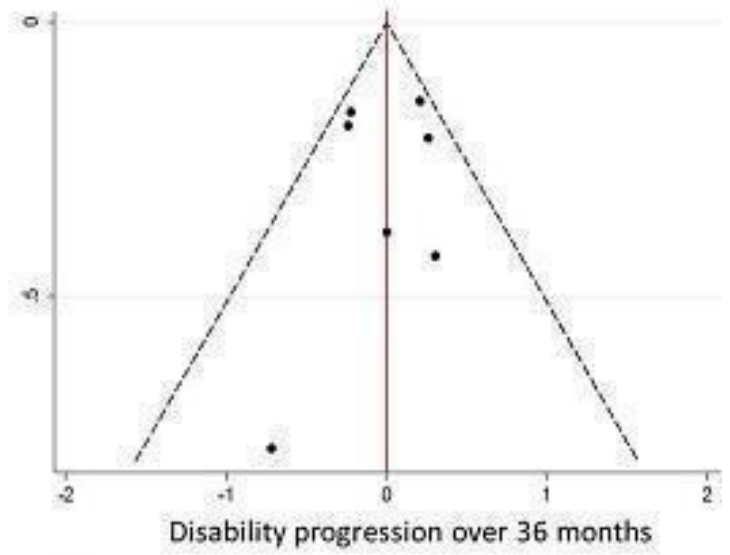

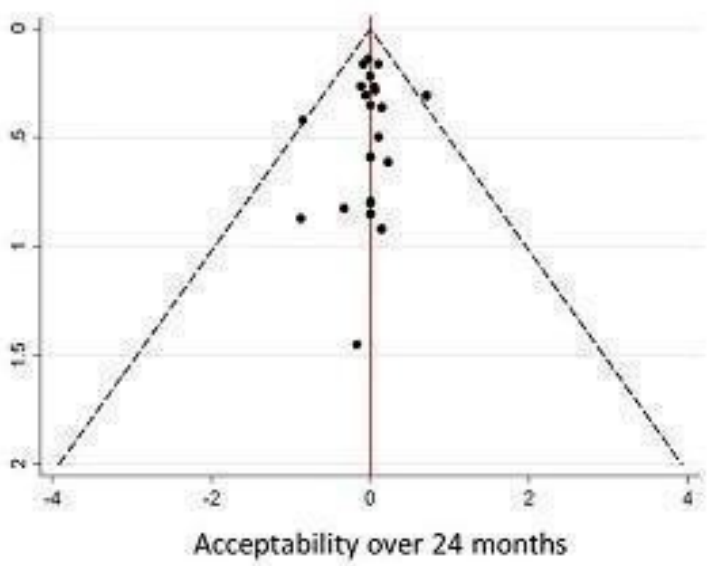

Immunomodulators and immunosuppressants for multiple sclerosis: a network meta-analysis (Review) 


\section{DISCUSSION}

\section{Summary of main results}

This review of the effects of treatments for MS included 44 RCTs with 17,401 randomised participants. The majority of studies were short-term trials, with the median RCT duration being 24 months, therefore the effects of these treatments beyond two years remain uncertain.

In terms of a protective effect against recurrence of relapses in RRMS during the first two years of treatment, natalizumab, IFNß1a (Rebif), IFNß-1b (Betaseron), glatiramer acetate, and mitoxantrone outperformed other drugs, being statistically significantly more effective than IFNß-1a (Avonex), azathioprine, methotrexate, cyclophosphamide, intravenous immunoglobulins, and longterm corticosteroids. The relapse outcome at three years' followup was not reported by any of the included trials for RRMS.

There were few studies providing data for the risk of clinical relapses in patients with progressive MS. Direct comparisons suggested that azathioprine decreased and IFNß-1b (Betaseron) decreased slightly the odds of participants with progressive MS having relapses over three years.

Disability progression was based on surrogate markers in the majority $(55 \%)$ of included studies that used serial in-trial upward changes of 0.5 or 1.0 point on the EDSS scale, confirmed at three months' follow-up or unconfirmed, reflecting an effect on relapserelated disability. Beyond two to three years, disability outcome data were unavailable or dropouts compromised the interpretation. From the network meta-analysis, mitoxantrone appeared to be the most effective agent at two years' follow-up, but our confidence in this result was graded as 'very low' using the GRADE approach. The direct comparison analysis suggested that natalizumab and IFNß-1a (Rebif) probably decreased the odds of participants with RRMS having disability progression at two years' follow-up, with an absolute reduction of $14 \%$ and $10 \%$, respectively. However, these findings also should be interpreted with caution because only one study was available for each of the two agents and both studies used a surrogate outcome to measure disability progression.

Both direct and indirect comparison revealed that none of the nine agents (IFNß-1b (Betaseron), IFNß-1a (Avonex or Rebif), glatiramer acetate, mitoxantrone, methotrexate, cyclophosphamide, intravenous immunoglobulins, and long-term corticosteroids) that were evaluated in included studies were effective in preventing disability worsening over two or three years in patients with progressive MS.
We found that there was not an important dose-effect relationship for any of the included treatments except for mitoxantrone, which appeared to be the most effective drug in delaying disability progression when administered intravenously at $12 \mathrm{mg} / \mathrm{m}^{2} /$ body surface area every three months.

All the agents included in this review were associated with a statistically significant higher rate of total withdrawals due to adverse events (AEs) compared to placebo, even if the network metaanalysis revealed that these agents did not differ from each other with regards to total withdrawals due to AEs. Information on serious adverse events (SAE) was available only for interferons, glatiramer acetate, natalizumab, mitoxantrone, and intravenous immunoglobulins. All of them, except interferons, were associated with a non-significantly higher rate of total SAEs compared with the control treatment during a median two years' follow-up period. Lack of statistical significance in our analyses was likely to have been caused by low quality, that is no active monitoring, an overall poor reporting of SAEs, and short follow-up in the included studies, as described in the limitations section.

Safety data from observational and registry studies need to be considered for medium and long-term SAEs associated with these treatments. Cutaneous necrosis (Nakamura 2008), thyroiditis ( Nonchev 2010), ophthalmological complications (Fragoso 2011), grade 3 or higher hepatotoxicity (Byrnes 2006), severe depression (Fragoso 2010), and haematological side effects (Nabavi 2011) were reported as significantly related to interferon $B$ treatment. Glatiramer acetate is associated with a number of SAEs including immediate post-injection reaction, anaphylaxis or hypersensitivity requiring emergency medical care, dyspnea, chest pain, lipoatrophy and skin necrosis, immunosuppression and infections, and decrease in pulmonary function. The most common adverse reactions ( $\geq 10 \%$ and $\geq 1.5$ times higher than placebo) reported in controlled studies were injection site reactions, vasodilatation, rash, dyspnea, and chest pain (FDA 2011).

Treatment with natalizumab is associated with an increased risk of progressive multifocal leukoencephalopathy (PML). A risk of PML of 11/1,000 users has been estimated for patients with all the following risk factors: the presence of anti-JC virus antibodies; longer duration of treatment, especially beyond two years; and prior treatment with an immunosuppressant medication (for example mitoxantrone, azathioprine, methotrexate, cyclophosphamide, or mycophenolate mofetil) (Bloomgren 2012).

A French cohort of 5354 MS patient-years was prospectively followed from 2001 to at least five years after initiation of mitoxantrone therapy (Le Page 2011). One out of 802 patients $(0.1 \%)$ presented with acute congestive heart failure and 39 out of 794 patients $(4.9 \%)$ presented with asymptomatic left ventricular ejection fraction reduction under $50 \%$ (persistent in 11 patients $(28 \%)$, transient in 27 patients $(69 \%)$, on the last scan at 
year five in one patient). Two cases of therapy-related leukaemia $(0.25 \%)$ were detected 20 months after the start of mitoxantrone (one death and one with eight years confirmed remission). Of the 317 women treated before the age of 45 years, $17.3 \%$ developed a persistent age-dependant amenorrhoea.

A possible long-term risk of cancer from azathioprine may be related to a treatment duration above 10 years and cumulative doses above $600 \mathrm{~g}$ (Casetta 2007).

Severe AEs leading to discontinuation of the treatment with intravenous immunoglobulins were noted in $4 \%$ of 84 treatment courses with a total 341 infusions under routine clinical conditions. They included thrombosis of the jugular vein, allergic reaction, and retrosternal pressure. However, based on the available literature, intravenous immunoglobulins can generally be regarded as a relatively safe treatment (Elovaara 2008).

\section{Overall completeness and applicability of evidence}

All eligible trials (up to November 2010) of agents that are currently used for treatment of MS were included in the review with the exception of fingolimod, for which trials had been not published when we were planning our review.

The findings presented in this review originated mostly from trials on the interferon $B$ family, glatiramer acetate, and natalizumab, which overall contributed outcome data for 9881 participants (66\%) included in 33 trials (75\%). The majority of the studies included RRMS participants, who represented $60 \%$ of those included in the review. Due to the few studies and data for participants with SPMS, PRMS, and PPMS, we decided to combine data for these phenotypes considering also that natural history studies show a similar disease course once onset of progression has manifested, independent of the prior history (Ebers 2006), and certainly over the two to three year time frame of the included trials.

Our review was not intended to be a comprehensive review of all effects of these treatments. We focused on three main clinical outcomes (relapses, disability progression, acceptability of treatment) that we considered clinically meaningful. Patient reported outcomes such as behavioural functions or quality of life were not included. They are certainly important outcomes for participants but are reported rarely in clinical trials, often without adequate monitoring and availability of appropriate published results. Different scales used and at different assessment time points do not allow comparisons to be made. Moreover, these measures may be susceptible to bias in trials in which many, if not most, treated participants have become aware of the treatment they are receiving owing to the well documented side effects of the treatments included in our review. Short duration trials and poor reporting of AEs were other major limitations in determining the overall completeness and the most favourable balance between benefits and risks of the included treatments.
Although magnetic resonance imaging (MRI) measures are widely used in trials of MS, we did not include them in this review since MRI alone adds little if anything to the clinical outcomes (Daumer 2009). Moreover, it was not possible to compare MRI outcomes adequately across trials from the published results since MRI criteria, measures, and the timing of the scans differed between trials.

\section{Quality of the evidence}

Five (11\%) out of 44 trials were judged to be at low risk of bias, when allocation concealment, blinding of outcome assessors and complete outcome data were met. In more than $50 \%$ of studies allocation concealment was judged to be 'unclear' due to the lack of details provided in the articles. Only two RCTs were judged at a 'high' risk of bias for allocation concealment. Blinding of outcome assessment was reported in the majority of the included studies; however side effects of each treatment make it likely that treated participants had become aware of the treatment they were receiving during the course of the trial, and most of these trials should be regarded as single-blind.

In our review a primary outcome was disability progression and its definition was taken from the original articles. All studies defined progression as a sustained (three month or six month) increase in EDSS (Kurtzke 1983) score by at least one point recorded outside of exacerbations throughout the follow-up. This is a validated measure of unremitting disability in MS, provided it is confirmed after a sufficient period of time (at least six months is necessary and one year would be better) (Ebers 2008). Twenty-four (54.5\%) of the 44 included trials required only three months of confirmation to assess sustained disability progression. Although we had to accept the definition given in the original papers, we considered the three month criterion to be at high risk of bias because this definition meant that participants who recovered slowly from exacerbations were regarded as having unremitting disability progression.

There were greater than $85 \%$ of participants followed-up in more than $50 \%$ of the included studies. Six trials were stopped early, two for benefit, three for futility, and one for lack of funding. Although protocols of the included studies were not available, the majority of them reported the number of participants who had relapses or disability progression, which were the primary efficacy outcomes in this review. However, in most trials these outcomes were reported at only two years' follow-up, that is a too short period to establish valid treatment efficacy in MS.

Only 20 RCTs reported that AEs were actively monitored, and only one study provided sufficient information on how a SAE was defined. More than $50 \%$ of studies did not report SAEs. Moreover, due to the short duration of follow-up in the majority of the trials, rare and long-term adverse events were not available. Therefore caution is needed in interpreting the apparent safety reported for most of the agents ("treatments appeared not statistically significantly different from placebo in terms of the number of participants with SAEs"). Given the low quality of monitoring adverse 
events and overall poor reporting in the included studies, it is difficult to understand whether an event actually did not happen or it happened but was not detected or was selectively not reported.

\section{Potential biases in the review process}

The studies were deemed sufficiently similar across comparisons and we believe that the consistency assumption is reasonable in this type of data. The models fit the data well, no loops were found to be inconsistent and model parsimony was always higher for the consistency model; this provided support for our assumption of consistency. However the power of these tests and approaches to detect inconsistency are low, particularly for networks with a small number of included studies. The possible presence of publication bias, partially supported by the contour-enhanced funnel plot, can never be totally excluded.

A small number of studies with few comparisons were recognised as having low risk of bias and in many cases results came from a single study. We couldn't predict the impact of industry sponsorship as most of the presented studies were sponsored by industry or the information was not reported.

In this review pairwise meta-analyses were performed in a frequentist approach while network meta-analyses were performed in a Bayesian context. Implementation of the models in the Bayesian framework yielded wider confidence intervals than frequentist implementation in STATA because the framework accounted for the uncertainty in the estimation of the heterogeneity. For some comparisons the estimate of network meta-analysis was less precise that the estimate from the pairwise meta-analysis. This happened when there was no heterogeneity in the pairwise comparison but there was heterogeneity overall in the network and random-effects models were used. This was because the network meta-analysis assumes a common 'average' heterogeneity parameter $\tau$ for all pairwise comparisons.

\section{Agreements and disagreements with other studies or reviews}

Our findings agree with and extend the findings of a previous review (Smith 2010) that examined all available RCTs (up to December 2009) of glatiramer acetate, IFNß-1a, IFNß-1b, mitoxantrone, and natalizumab. They also reported that there was fair evidence that IFNß-1a (Avonex) was less effective than IFNß-1a (Rebif) and IFNß-1b for preventing relapse in patients with RRMS. They found no difference between the interferons on changes in disability but did find IFNß-1b to be superior to IFNß-1a (Avonex) on disease progression (relative risk $0.48,95 \%$ CI 0.27 to 0.86 ) in RRMS. They confirmed our findings that evidence was insufficient to make any judgments regarding effectiveness in primary progressive or secondary progressive MS. They did not find any difference in withdrawal rates among the interferon $B$ family in head-to-head trials.

Zintzaras 2012 performed a network meta-analysis of 109 trials and compared different therapies commonly used for MS, but also many agents that are not currently in clinical use, such as bovine myelin, or that were rejected by the FDA and the EMA because they were found to cause toxicity, such as cladribine. The metaanalysis considered 145 arms as different treatments (that is one for each dose of each treatment) compared to IFNB-1b $(250 \mu \mathrm{g})$ (that is the chosen reference treatment for analysis) and provided about 90 estimates based on eight direct comparisons with IFNß$1 b$. Thus, the remaining estimates were obtained through the use of indirect analysis. The authors reported that their results needed to be interpreted with caution because the network was dominated by indirect comparisons, but they claimed that combination therapies could be more promising than monotherapies. Important facts invalidate this conclusion in our opinion. First, this claim came only from indirect comparisons. Second, combined treatments did not affect clinical outcomes any more than the comparison treatment alone or resulted in a worst outcome. For example, methylprednisolone in combination with IFNß-1a did not affect disability progression any more than IFNß-1a alone (Ravnborg 2010), or atorvastatin combined with IFNß-1a resulted in increased MRI and clinical disease activity (Birnbaum 2008). Third, some of the primary studies included in the indirect analysis were phase two small trials (Birnbaum 2008; Goodman 2009; Weiner 1993) or used no validated clinical outcomes to assess treatment effects (Khoury 2010). Fourth, combination therapies increased the frequency of SAEs.

In a retrospective cohort study (Shirani 2012) based on prospectively collected data (1985 to 2008) from British Columbia, Canada, patients with RRMS treated with interferon $\beta(n=868)$ were compared with untreated contemporary $(n=829)$ and historical $(\mathrm{n}=959)$ cohorts. The median active follow-up times (first to last EDSS measurement) were 5.1, 4.0, and 10.8 years, respectively. The authors concluded that among patients with RRMS, administration of interferon $\beta$ was not associated with a reduction in progression of disability.

\section{AUTHORS' CONCLUSIONS}

\section{Implications for practice}

Our review includes direct and indirect comparisons of immunotherapies for MS and should provide some guidance to clinicians and patients on their efficacy. On the basis of high quality evidence, natalizumab and IFNß-1a (Rebif) are superior to all other treatments for preventing clinical relapses and disability progression in the short-term ( 24 months) in patients with RRMS. Natalizumab can induce progressive multifocal leukoencephalopathy, especially with more than two years of treatment.

Moderate quality data support the efficacy of IFNß-1b (Betaseron), glatiramer acetate, and mitoxantrone for preventing relapse and disability progression in RRMS in the short-term. All 
these treatments are associated with medium and long term serious adverse events and the benefit-risk balance might be unfavourable.

There are insufficient high quality data for a definitive conclusion on whether there is a favourable benefit-risk balance with azathioprine, however this agent might be effective in decreasing the odds of participants with RRMS having clinical relapses and disability progression over 24 to 36 months.

The lack of convincing efficacy data from both direct and indirect comparisons shows that IFNß-1a (Avonex), intravenous immunoglobulins, cyclophosphamide, and long-term corticosteroids have an unfavourable benefit-risk balance in RRMS.

Few randomised studies are available for patients with progressive MS. In comparison with placebo, IFNß-1b (Betaseron) and azathioprine decrease slightly the odds of these patients having clinical relapses over three years. IFNß-1a (Avonex or Rebif), glatiramer acetate, mitoxantrone, methotrexate, cyclophosphamide, intravenous immunoglobulins, and long-term corticosteroids are not effective in decreasing disability progression in patients with progressive MS.

There is a dose-effect associated with mitoxantrone administered intravenously at $12 \mathrm{mg} / \mathrm{m}^{2} /$ body surface area every three months, but the risk of serious adverse events (cardiotoxicity and therapyrelated leukaemia) unfavourably influences the benefit-risk balance. There is not a dose-effect associated with the use of all the other treatments included in our review.

It is important to consider that the clinical effects of all these treatments beyond two years are uncertain, and this is a relevant point for a disease of 30 to 40 years duration.

More than $70 \%$ of included studies were sponsored by pharmaceutical companies and this could have influenced the results of our review.

\section{Implications for research}

We believe that there are two urgent needs that the research agenda should address. First, large randomised trials of direct comparisons are needed and follow-up of the original trial cohorts should be mandatory. Direct head-to-head comparison(s) between natalizumab and IFNß-1a (Rebif) or between azathioprine and IFNß1a (Rebif) should be top priority on the research agenda.

Second, more studies regarding the medium and long-term efficacy and safety of immunotherapies and the comparative safety of different agents are needed. As the number of drugs, including biologics, that are available for treatment of MS increases, more options will become available to participants and clinicians. In the absence of comparative trials, national and international registries and other types of large non-randomised studies might be relevant sources for providing complementary data regarding the long-term effectiveness and safety of immunotherapies for MS.

\section{ACKNOWLEDGEMENTS}

We thank Loredana La Mantia, Tianjign Li, Silvana Simi, Maurizio Leone, Sten Fredrickson, and the Cochrane Comparing Multiple Interventions Methods Group (CMIMG) for useful comments during the preparation of the manuscript.

We also express our gratitude for the assistance and guidance of Toby Lasserson, Harriet MacLehose and David Tovey for reviewing this paper.

GF and the review were funded by a grant from the Italian Health Ministry - Direction of the Scientific Research and Technology, Italy. The project was included in the Strategic Program 2007 "Therapy for MS". GS received support for dose-response data analysis from the European Research Council (Grant Agreement Number 260559 IMMA).

\section{RE F E R E N C E S}

\section{References to studies included in this review}

\section{Achiron 1998 \{published data only\}}

Achiron A, Gabbay U, Gilad R, Hassin B, Barak Y, Gornish $\mathrm{M}$, et al.Intravenous immunoglobulin treatment in multiple sclerosis. Effect on relapses. Neurology 1998;50 (2):398-402.

\section{AFFIRM 2006 \{published data only\}}

Polman CH, O'Connor PW, Havrdova E, Hutchinson

M, Kappos L, Miller DH, et al.A randomized, placebocontrolled trial of natalizumab for relapsing multiple sclerosis. The New England Journal of Medicine 2006;354 (9):899-910.
Andersen 2004 \{published data only\} Andersen O, Elovaara I, Farkkila M, Hansen HJ, Mellgren SI, Myhr KM, et al.Multicentre, randomised, double blind, placebo controlled, phase III study of weekly, low dose, subcutaneous interferon beta-1a in secondary progressive multiple sclerosis. Journal of Neurology, Neurosurgery, and Psychiatry 2004;75(5):706-10. [PUBMED: 15090564]

\section{BEYOND 2009 \{published data only\}}

O'Connor P, Filippi M, Arnason B, Comi G, Cook S, Goodin D, et al.250 microg or 500 microg interferon beta$1 \mathrm{~b}$ versus $20 \mathrm{mg}$ glatiramer acetate in relapsing-remitting multiple sclerosis: a prospective, randomised, multicentre study. Lancet Neurology 2009;8(10):889-97. 
Bornstein 1987 \{published data only\}

Bornstein MB, Miller A, Slagle, S, Weitzman M, Crystal, et al.A pilot trial of Cop 1 in exacerbating-remitting multiple sclerosis. The New England Journal of Medicine 1987; Vol. 317 , issue 7:408-14.

Bornstein 1991 \{published data only\}

Bornstein MB, Miller A, Slagle S, Weitzman M, Drexler E, Keilson Metal. A placebo-controlled, double-blind, randomised, two-center, pilot trial of Cop 1 in chronic progressive multiple sclerosis. Neurology 1991;41:533-9. [: DOI]

BPSM 1995 \{published data only\}

Ciccone A, Beretta S, Brusaferri F, Galea I, Protti A, Spreafico C. Corticosteroids for the long-term treatment in multiple sclerosis. Cochrane Database of Systematic Reviews 2008, Issue 1. [DOI: 10.1002/14651858.CD006264.pub2]

British and Dutch 1988 \{published data only\} The British, Dutch MSATG. Double-masked trial of azathioprine in multiple sclerosis. Lancet 1988; Vol. 2, issue 8604:179-83.

\section{CCMSSG 1991 \{published data only\}}

CCMSSG. The Canadian cooperative trial of cyclophosphamide and plasma exchange in progressive multiple sclerosis. Lancet 1991;337(8739):441-6.

Comi 2001 \{published data only\}

Comi G, Filippi M, Wolinsky JS. European/Canadian multicenter, double-blind, randomized, placebo-controlled study of the effects of glatiramer acetate on magnetic resonance imaging--measured disease activity and burden in patients with relapsing multiple sclerosis. European/ Canadian Glatiramer Acetate Study Group. Annals of Neurology 2001;49(3):290-7. [PUBMED: 11261502]

Edan 1997 \{published data only\}

Edan G, Miller D, Clanet M, Confavreux C, Lyon-Caen $\mathrm{O}$, Lubetzki $\mathrm{C}$, et al.Therapeutic effect of mitoxantrone combined with methylprednisolone in multiple sclerosis: a randomised multicentre study of active disease using MRI and clinical criteria. Journal of Neurology, Neurosurgery, and Psychiatry 1997;62(2):112-8. [: DOI]

Ellison 1989 \{published data only\}

Ellison G, Myers L, Mickey M, Graves M, Tourtellotte W, Syndulko K, et al.A placebo-controlled, randomized, double-masked, variable dosage, clinical trial of azathioprine with and without methylprednisolone in multiple sclerosis. Neurology 1989;39(8):1018-26.

Etemadifar 2006 \{published data only\}

Etemadifar M, Janghorbani M, Shaygannejad V.

Comparison of Betaferon, Avonex, and Rebif in treatment of relapsing-remitting multiple sclerosis. Acta Neurologica Scandinavica 2006;113(5):283-7.

European Study Group 1998 \{published data only\} European Study Group. Placebo-controlled multicentre randomised trial of interferon beta- $1 \mathrm{~b}$ in treatment of secondary progressive multiple sclerosis. European Study Group on interferon beta-1b in secondary progressive MS. Lancet 1998;352(9139):1491-7. [PUBMED: 9820296]
EVIDENCE 2007 \{published data only\}

Schwid S, Panitch H. Full results of the Evidence of Interferon Dose-Response-European North American Comparative Efficacy (EVIDENCE) study: a multicenter, randomized, assessor-blinded comparison of low-dose weekly versus high-dose, high-frequency interferon beta-1a for relapsing multiple sclerosis. Clinical Therapeutics 2007; 29(9):2031-48. [PUBMED: 18035202]

Fazekas 1997 \{published data only\}

Fazekas F, Deisenhammer F, Strasser-Fuchs S, Nahler G, Mamoli B. Randomised placebo-controlled trial of monthly intravenous immunoglobulin therapy in relapsing-remitting multiple sclerosis. Lancet 1997;349(9052):589-93.

Fazekas 2008 \{published data only\} Fazekas F, Lublin F, Li D, Freedman M, Hartung H, Rieckmann P, et al.Intravenous immunoglobulin in relapsing-remitting multiple sclerosis: a dose-finding trial. Neurology 2008;71(4):265-71.

Ghezzi 1989 \{published data only\}

Ghezzi A, Di Falco M, Locatelli C. In: Consette RE, Delmotte P editor(s). Clinical controlled randomized trial of azathioprine in multiple sclerosis. Elsevier, 1989.

\section{Goodkin 1991 \{published data only\}} Goodkin D, Bailly R, Teetzen M, Hertsgaard D, Beatty W. The efficacy of azathioprine in relapsing-remitting multiple sclerosis. Neurology 1991;41:20-5. [: DOI]

Goodkin 1995 \{published data only\} Goodkin D, Rudick R, VanderBrug Medendorp S, Daughtry M, Schwetz K, Fischer J, et al.Low-dose $(7.5 \mathrm{mg})$ oral methotrexate reduces the rate of progression in chronic progressive multiple sclerosis. Annals of Neurology 1995;37 (1):30-40. [PUBMED: 7818255]

Hartung 2002 \{published data only\} Hartung H, Gonsette R, Konig N, Kwiecinski H, Guseo A, Morrissey $S$, et al.Mitoxantrone in progressive multiple sclerosis: a placebo-controlled, double-blind, randomised, multicentre trial. Lancet 2002;360(9350):2018-25.

[PUBMED: 12504397]

Hommes 2004 \{published data only\} Hommes O, Sorensen P, Fazekas F, Enriquez M, Koelmel $\mathrm{H}$, Fernandez $\mathrm{O}$, et al.Intravenous immunoglobulin in secondary progressive multiple sclerosis: randomised placebo-controlled trial. Lancet 2004;364(9440):1149-56.

IFNB MS Group 1993 \{published data only\} IFNB MSG. Interferon beta-1b is effective in relapsingremitting multiple sclerosis. I. Clinical results of a multicenter, randomized, double-blind, placebo-controlled trial. The IFNB Multiple Sclerosis Study Group. Neurology 1993;43(4):655-61. [PUBMED: 8469318]

IMPACT 2002 \{published data only\}

Cohen J, Cutter G, Fischer J, Goodman A, Heidenreich F, Kooijmans M, et al.Benefit of interferon beta-1a on MSFC progression in secondary progressive MS. Neurology 2002; 59(5):679-87. [PUBMED: 12221157] 


\section{INCOMIN 2002 \{published data only\}}

Durelli L, Verdun E, Barbero P, Bergui M, Versino E, Ghezzi A, et al.Every-other-day interferon beta- $1 \mathrm{~b}$ versus once-weekly interferon beta-1a for multiple sclerosis: results of a 2-year prospective randomised multicentre study (INCOMIN). Lancet 2002;359:1453-60.

Johnson 1995 \{published data only\}

Johnson K, Brooks B, Cohen J, Ford C, Goldstein J, Lisak $\mathrm{R}$, et al.Copolymer 1 reduces relapse rate and improves disability in relapsing-remitting multiple sclerosis: results of a phase III multicenter, double-blind placebo-controlled trial. The Copolymer 1 Multiple Sclerosis Study Group. Neurology 1995;45(7):1268-76. [PUBMED: 7617181]

\section{Knobler 1993 \{published data only\}}

Knobler R, Greenstein J, Johnson K, Lublin F, Panitch H, Conway K, et al.Systemic recombinant human interferonbeta treatment of relapsing-remitting multiple sclerosis: pilot study analysis and six-year follow-up. Journal of Interferon Research 1993;13:333-40. [PUBMED: 8301153]

Koch-Henriksen 2006 \{published data only\}

Koch-Henriksen N, Sørensen P, Christensen T, Frederiksen J, Ravnborg M, Jensen K, et al.A randomised study of two interferon-beta treatments in relapsing-remitting multiple sclerosis. Neurology 2006;66(7):1056-60.

Leary 2003 \{published data only\}

Leary S, Miller D, Stevenson V, Brex P, Chard D, Thompson A. Interferon beta-1a in primary progressive MS: an exploratory, randomized, controlled trial. Neurology 2003; 60(1):44-51. [PUBMED: 12525716]

Lewanska 2002 \{published data only\}

Lewanska M, Siger Zajdel M, Selmaj K. No difference in efficacy of two different doses of intravenous immunoglobulins in MS: clinical and MRI assessment. European Journal of Neurology 2002;9(6):565-72.

\section{Likosky 1991 \{published data only\}}

Likosky W, Fireman B, Elmore R, Eno G, Gale K, Goode $\mathrm{G}$, et al.Intense immunosuppression in chronic progressive multiple sclerosis: the Kaiser study. Journal of Neurology, Neurosurgery, and Psychiatry 1991; Vol. 54, issue 12: 1055-60.

Milanese 1993 \{published data only\}

Milanese C, La Mantia L, Salmaggi A, Eoli M. A double blind study on azathioprine efficacy in multiple sclerosis: final report. Journal of Neurology 1993;240(5):295-8.

Millefiorini 1997 \{published data only\} Millefiorini E, Gasperini C, Pozzilli C, D'Andrea F, Bastianello S, Trojano M, et al.Randomized placebocontrolled trial of mitoxantrone in relapsing-remitting multiple sclerosis: 24-month clinical and MRI outcome. Journal of Neurology 1997;244(3):153-9. [PUBMED: 9050955]

Miller 1961 \{published data only\} Miller H, Newell D, Ridley A. Multiple sclerosis. Trials of maintenance treatment with prednisolone and soluble aspirin. Lancet 1961; Vol. 1, issue 7169:127-9.
Montalban 2009 \{published data only\}

Montalban X, Sastre-Garriga J, Tintore M, Brieva L, Aymerich F, Rio J, et al.A single-center, randomized, doubleblind, placebo-controlled study of interferon beta- $1 \mathrm{~b}$ on primary progressive and transitional multiple sclerosis. Multiple Sclerosis 2009;15(10):1195-205. [PUBMED: 19797261]

MSCRG 1996 \{published data only\} Jacobs L, Cookfair D, Rudick R, Herndon R, Richert J, Salazar A, et al.Intramuscular interferon beta-1a for disease progression in relapsing multiple sclerosis. The Multiple Sclerosis Collaborative Research Group (MSCRG). Annals of Neurology 1996;39:285-94.

\section{NASP 2004 \{published data only\}}

Panitch H, Miller A, Paty D, Weinshenker B. Interferon beta- $1 \mathrm{~b}$ in secondary progressive MS: results from a 3year controlled study. Neurology 2004;63(10):1788-95. [PUBMED: 15557491]

OWIMS 1999 \{published data only\} OWIMS. Evidence of interferon beta-1a dose response in relapsing-remitting MS: the OWIMS Study. The Once Weekly Interferon for MS Study Group. Neurology 1999;53 (4):679-86. [PUBMED: 10489026]

Pohlau 2007 \{published data only\} Pohlau D, Przuntek H, Sailer M, Bethke F, Koehler J, Konig N, et al.Intravenous immunoglobulin in primary and secondary chronic progressive multiple sclerosis: a randomized placebo controlled multicentre study. Multiple Sclerosis 2007;13(9):1107-17. [PUBMED: 17623736]

PRISMS 1998 \{published data only\} PRISMS. Randomised double-blind placebo-controlled study of interferon beta-1a in relapsing/remitting multiple sclerosis. PRISMS (Prevention of Relapses and Disability by Interferon beta-1a Subcutaneously in Multiple Sclerosis) Study Group. Lancet 1998;352(9139):1498-504. [PUBMED: 9820297]

REGARD 2008 \{published data only\}

Mikol D, Barkhof F, Chang P, Coyle P, Jeffery D, Schwid $S$, et al.Comparison of subcutaneous interferon beta-1a with glatiramer acetate in patients with relapsing multiple sclerosis (the REbif vs Glatiramer Acetate in Relapsing MS Disease [REGARD] study): a multicentre, randomised, parallel, open-label trial. Lancet Neurology 2008;7(10): 903-14.

SENTINEL 2006 \{published data only\} Rudick R, Stuart W Calabresi P, Confavreux C, Galetta $\mathrm{S}$, Radue E, et al.Natalizumab plus interferon beta-1a for relapsing multiple sclerosis. The New England Journal of Medicine 2006;354(9):911-23.

SPECTRIMS 2001 \{published data only\} SPECTRIMS. Randomized controlled trial of interferonbeta-1a in secondary progressive MS: Clinical results. Neurology 2001;56(11):1496-504. [PUBMED: 11402106]

Wolinsky 2007 \{published data only\} Wolinsky J, Narayana P, O'Connor P, Coyle P, Ford C, Johnson $\mathrm{K}$, et al.Glatiramer acetate in primary progressive 
multiple sclerosis: results of a multinational, multicenter, double-blind, placebo-controlled trial. Annals of Neurology 2007;61(1):14-24. [PUBMED: 17262850]

\section{References to studies excluded from this review}

Arnason 1999 \{published data only\}

Arnason, BGW, Jacobs G, Hanlon M, Harding B, Noronha $\mathrm{ABC}$, Auty A, et al.TNF neutralization in MS: Results of a randomized, placebo-controlled multicenter study. Neurology 1999;53(3):457-65.

Barkhof 2003 \{published data only\}

Barkhof F, Rocca M, Francis G, Van Waesberghe JH, Uitdehaag BM, Hommes OR, et al.Validation of diagnostic magnetic resonance imaging criteria for multiple sclerosis and response to interferon beta 1a. Annals of Neurology 2003;53(3):718-24.

Baum 2006 \{published data only\}

Baum K, Mannitol Formulation Study Group. Safety and tolerability of a 'refrigeration-free' formulation of interferon beta-1b--results of a double-blind, multicentre, comparative study in patients with relapsing-remitting or secondary progressive multiple sclerosis. The Journal of International Medical Research 2006;34(1):1-12.

BENEFIT 2006 \{published data only\}

Kappos L, Polman C, Freedman M, Edan G, Hartung H, Miller $\mathrm{D}$, et al.Treatment with interferon beta- $1 \mathrm{~b}$ delays conversion to clinically definite and McDonald MS in patients with clinically isolated syndromes. Neurology 2006; 67(7):1242-9.

Boiko 2001 \{published data only\}

Boiko A, Skurkovich S, Buglak A, Alekseeva, T, Smirnova N, Skurkovich B, et al.Randomized, placebo-controlled trial comparing short course of anti-IFN? And anti-TNFa showed only anti-IFN? Effective in secondary progressive MS. Journal of Neurosurgery 2001;187 Suppl 1:S456.

Burton 2009 \{published data only\}

Burton J, O’Connor P, Hohol M, Beyene J. Oral versus intravenous steroids for treatment of relapses in multiple sclerosis. Cochrane Database of Systematic Reviews 2009, Issue 3. [DOI: 10.1002/14651858.CD006921.pub2]

CHAMPS 2000 \{published data only\}

Jacobs L, Beck R, Simon J, Kinkel R, Brownscheidle C, Murray T, et al.Intramuscular interferon beta-1a therapy initiated during a first demyelinating event in multiple sclerosis. CHAMPS Study Group. The New England Journal of Medicine 2000;343(13):898-904. [PUBMED: 11006365]

Christodoulou 2006 \{published data only\} Christodoulou C, Melville P, Scherl WF, MacAllister WS, Elkins LE, Krupp LB. Effects of donepezil on memory and cognition in multiple sclerosis. Journal of the Neurological Sciences 2006;245(1-2):127-36.

Clanet 2002 \{published data only\}

Clanet M, Radue E, Kappos L, Hartung H, Hohlfeld

$\mathrm{R}$, Sandberg-Wollheim M, et al.A randomized, double- blind, dose-comparison study of weekly interferon beta1a in relapsing MS. Neurology 2002;59(10):1507-17. [PUBMED: 12451189]

Durelli 1994 \{published data only\}

Durelli L, Bongioanni M, Cavallo R, Ferrero B, Ferri R, Ferrio $\mathrm{M}$, et al.Chronic systemic high-dose recombinant interferon alfa-2a reduces exacerbation rate, MRI signs of disease activity, and lymphocyte interferon gamma production in relapsing-remitting multiple sclerosis. Neurology 1994;44(3 (Pt 1)):406-13.

ETOMS 2001 \{published data only\}

Comi G, Filippi M, Barkhof F, Durelli L, Edan G, Fernández $\mathrm{O}$, et al.Effect of early interferon treatment on conversion to definite multiple sclerosis: a randomised study. Lancet 2001;357(9268):1576-82.

Fernandez 2002 \{published data only\}

Fernandez O, Guerrero M, Mayorga C, Munoz L, Lean A, Luque $\mathrm{G}$, et al.Combination therapy with interferon beta- $1 \mathrm{~b}$ and azathioprine in secondary progressive multiple sclerosis. A two-year pilot study. Journal of Neurology 2002; 249(8):1058-62.

Filippi 2004 \{published data only\}

Filippi M, Rovaris M, Inglese M, Barkhof F, De Stefano $\mathrm{N}$, Smith $\mathrm{S}$, et al.Interferon beta-1a for brain tissue loss in patients at presentation with syndromes suggestive of multiple sclerosis: a randomised, double blind, placebocontrolled trial. Lancet 2004;364(9444):1489-96.

Filippi 2006 \{published data only\} Filippi M, Wolinsky J, Comi G. Effects of oral glatiramer acetate on clinical and MRI-monitored disease activity in patients with relapsing multiple sclerosis: a multicentre, double-blind, randomised, placebo-controlled study. Lancet Neurology 2006;5:213-20.

GLANCE 2009 \{published data only\}

Goodman A, Rossman H, Bar-Or A, Miller A, Miller D, Schmierer K, et al.GLANCE: Results of a phase 2, randomized, double-blind, placebo-controlled study. Neurology 2009;72:806-12.

Goodkin 2000 \{published data only\} Goodkin DE, Shulman M, Winkelhake J, Waubant E, Andersson P, Stewart T, et al.A phase I trial of solubilized DR2:MBP84-102 (AG284) in multiple sclerosis. Neurology 2000;54(7):1414.

Hauser 1983 \{published data only\} Hauser S, Dawson D, Lehrich J, Beal M, Kevy S, Propper $\mathrm{R}$, et al.Intensive immunosuppression in progressive multiple sclerosis. A randomized, three-arm study of highdose intravenous cyclophosphamide, plasma exchange and ACTH [comment in: N Engl J Med 1983;309:239-40; comment in: N Engl J Med 1983;309:241; comment in: Lancet 1991;337:1540-1]. The New England Journal of Medicine 1983;308(4):173-80.

Hoogervorst 2002 \{published data only\} Hoogervorst EL, Polman CH, Barkhof F. Cerebral volume changes in multiple sclerosis patients treated with high-dose 
intravenous methylprednisolone. Multiple Sclerosis 2002;8

(5):415-9.

Labetouelle 2001 \{published data only\}

Labetouelle M. [About the article: "Intramuscular interferon beta-1a therapy initiated during a first demyelinating event in multiple sclerosis" by Jacobs LD et al]. Journal Francais of Ophthalmology 2001;24(2):222.

Liu 2010 \{published data only\}

Liu J, Wang L, Zhan S, Tan J, Xia Y. Daclizumab for relapsing remitting multiple sclerosis. Cochrane Database of Systematic Reviews 2010, Issue 6. [DOI: 10.1002/ 14651858.CD008127.pub2; : CD008127]

Myhr 1999 \{published data only\}

Myhr K, Riise T, Green L, Beiske T, Celius E, Edland A, et al.Interferon-alpha2a reduces MRI disease activity in relapsing-remitting multiple sclerosis. Norwegian Study Group on Interferon-alpha in Multiple Sclerosis. Neurology 1999;52(5):1049-56. [MEDLINE: 99200550]

Patti 1999 \{published data only\}

Patti F, L'Episcopo MR, Cataldi ML, Reggio A. Natural interferon-beta treatment of relapsing-remitting and secondary-progressive multiple sclerosis patients. A twoyear study. Acta Neurologica Scandinavica 1999;100(5): 283-9.

Rio 2007 \{published data only\}

Río J, Tintoré M, Nos C, Téllez N, Galán I, Pelayo R, et al.Interferon beta in secondary progressive multiple sclerosis. Daily clinical practice. Journal of Neurology 2007; 254:849-53.

Skurkovich 2001 \{published data only\} Skurkovich S, Boiko A, Beliaeva I, Buglak A, Alekseeva T, Smirnova N, et al.Randomized study of antibodies to IFNgamma and TNF-alpha in secondary progressive multiple sclerosis. Multiple Sclerosis 2001;7(5):277-84.

Steultjens 2003 \{published data only\}

Steultjens E, Dekker J, Bouter L, Cardol M, Van den Ende E, van de Nes J. Occupational therapy for multiple sclerosis. Cochrane Database of Systematic Reviews 2003, Issue 3. [DOI: 10.1002/14651858.CD003608; : CD003608]

Tejani 2010 \{published data only\} Tejani A, Wasdell M, Spiwak R, Rowell G, Nathwani S. Carnitine for fatigue in multiple sclerosis. Cochrane Database of Systematic Reviews 2010, Issue 2. [DOI: 10.1002/14651858.CD007280.pub2; : CD007280]

Tubridy 1999 \{published data only\} Tubridy N, Behan PO, Capildeo R, Chaudhuri A, Forbes $\mathrm{R}$, Hawkins CP, et al.The effect of anti-[alpha] 4 integrin antibody on brain lesion activity in MS. Neurology 1999;53 (3):466-72

Van de Wyngaert 2001 \{published data only\} van de Wyngaert F, Beguin C, D’Hooghe M, Dooms G, Lissoir F, Carton H, et al.A double-blind clinical trial of mitoxantrone versus methylprednisolone in relapsing, secondary progressive multiple sclerosis. Acta Neurologica Belgica 2001;101(4):210-6.
Wender 1988 \{published data only\}

Wender M, Tokarz-Kupczyk E, Mularek O. Early results of the treatment of chronic progressive forms of multiple sclerosis with cyclophosphamide and ACTH [Wczesne wyniki leczenia postaci przewlekle postepujacych stwardnienia rozsianego cyklofosfamidem i ACTH]. Neurologia i Neurochirurgia Polska 1988;22(5):399-403.

Zavalishin 2003 \{published data only\} Zavalishin IA, Gusev EI, Iakhno NN, Skoromets AA, Ko AN, Demina TL, et al.Results of a multicenter study of Rebif-22 mcg administration in Russia. Zhurnal Nevrologii i Psikhiatrii Imeni S.S. Korsakova / Ministerstvo zdravookhraneniia i meditsinskoi promyshlennosti Rossiiskoi Federatsii, Vserossiiskoe obshchestvo nevrologov [i] Vserossiiskoe obshchestvo psikhiatrov 2003;Spec No 2:S73-8.

Zivadinov 2001 \{published data only\}

Zivadinov R, Rudick R, De Masi R, Nasuelli D, Ukmar M, et al.Effects of IV methylprednisolone on brain atrophy in relapsing-remitting MS. Neurology 2001;57(7):1239-47.

\section{Additional references}

\section{Association of British Neurologists 2005}

Association of British Neurologists 2005. Guidelines for the Use of Intravenous Immunoglobulin in Neurological Diseases. www.theabn.org/documents/IVIg-Guidelines 2005. [: OTHER]

\section{Bennett 2009}

Bennett J, Stüve O. Update on inflammation, neurodegeneration, and immunoregulation in multiple sclerosis: therapeutic implications. Clinical Neuropharmacology 2009;32(3):121-32.

Billiau 2004

Billiau A, Kieseier B, Hartung H. Biologic role of interferon beta in multiple sclerosis. Journal of Neurology 2004;251 Suppl 2:II10-4.

Birnbaum 2008

Birnbaum G, Cree B, Altafullah I, Zinser M, Reder A. Combining beta interferon and atorvastatin may increase disease activity in multiple sclerosis. Neurology 2008;71 (18):1390-5.

Bloomgren 2012

Bloomgren G, Richman S, Hotermans C, Subramanyam M, Goelz S, Natarajan A, et al.Risk of natalizumab-associated progressive multifocal leukoencephalopathy. The New England journal of medicine 2012;366(20):1870-80.

Byrnes 2006

V Byrnes, N Afdhal, T Challies, PE Greenstein. Drug induced liver injury secondary to interferon-beta (IFN- $\beta$ ) in multiple sclerosis. Annals of Hepatology 2006;5(1):56-9.

\section{Calabresi 1991}

Calabresi P, Chabner B. Antineoplastic agents. In: Goodman, Gillman's. Hardman JGLimbird LE, Molinoff PB, Ruddon RW, Goodman Gillman A editor(s). Goodman \& Gillman's. The Pharmacological Basis of Therapeutics. 
Eighth. Vol. II, New York: Pergamon Press, 1991: 1209-23.

\section{Caldwell 2005}

Caldwell D, Ades A, Higgins J. Simultaneous comparison of multiple treatments: combining direct and indirect evidence as well. BMJ 2005;331(7521):897-900.

Casetta 2007

Casetta I, Iuliano G, Filippini G. Azathioprine for multiple sclerosis. Cochrane Database of Systematic Reviews 2007, Issue 4 Art. No.: CD003982. [DOI: 10.1002/ 14651858.CD003982.pub2]

Chaimani 2012

Chaimani A, Salanti G. Using network meta-analysis to evaluate the existence of small-study effects in a network of interventions. Res Synth Method 2012;3:161-176.

\section{Ciccone 2008}

Ciccone A, Beretta S, Brusaferri F, Galea I, Protti A, Spreafico C. Corticosteroids for the long-term treatment in multiple sclerosis. Cochrane Database of Systematic Reviews 2008, Issue 1. [DOI: 10.1002/14651858.CD006264]

\section{Compston 2002}

Compston A, Coles A. Multiple sclerosis. Lancet 2002;359: 1221-31.

\section{Daumer 2009}

Daumer M, Neuhaus A, Morrissey S, Hintzen R, Ebers G. MRI as an outcome in multiple sclerosis clinical trials. Neurology 2009;72:705-11.

Del Giovane 2013

Del Giovane C, Vacchi L, Mavridis D, Filippini G, Salanti G. Network meta-analysis models to account for variability in treatment definitions: application to dose effects. Statistics in Medicine 2013;32(1):25-39.

DerSimonian 1986

DerSimonian R, Laird N. Meta-analysis in clinical trials. Controlled Clinical Trials 1986;7:177-88.

Ebers 2006

Ebers G. Disease evolution in multiple sclerosis. Journal of Neurology 2006;253 Suppl 6:3-8.

Ebers 2008

Ebers G, Heigenhauser L, Daumer M, Lederer C, Noseworthy J. Disability as an outcome in MS clinical trials. Neurology 2008;71:624-31.

\section{Elovaara 2008}

Elovaara I, Apostolski S, van Doorn P, Gilhus N, Hietaharju A, Honkaniemi J, et al.EFNS guidelines for the use of intravenous immunoglobulin in treatment of neurological diseases: EFNS task force on the use of intravenous immunoglobulin in treatment of neurological diseases. European Journal of Neurology 2008;15(9):893-908.

EMEA 2002

European Agency for the Evaluation of Medicinal Products. Committee for Proprietary Medicinal Products European Public Assessment Report (EPAR): Betaferon. London: EMEA 2002.
FDA 1993

U.S. Food, Drug Administration. Betaseron Interferon BETA-1B Subcutaneous. Drug Approval Package- Licensing Action 07/23/1993. http://www.accessdata.fda.gov/ drugsatfda docs/nda/pre96/103471s0000TOC.cfm.

\section{FDA 1996}

U.S. Food, Drug Administration. Glatiramer acetate (Copaxone) Product Approval Information Licensing Action 12/20/1996. http://www.accessdata.fda.gov/ scripts/cder/drugsatfda/index.cfm?fuseaction= Search.Label 'ApprovalHistory\#apphist.

\section{FDA 2000}

U.S. Food, Drug Administration. Mitoxantrone (Novantrone) Product Approval Information Licensing Action Approval Date: 1/28/2000. http: //www.accessdata.fda.gov/Scripts/cder/DrugsatFDA/ index.cfm?fuseaction=Search.DrugDetails.

\section{FDA 2001}

U.S. Food, Drug Administration. Interferon $1 \mathrm{~b}$ (Betaseron) treatment of secondary progressive forms of multiple sclerosis. Clinical review of the June 28, 2000 amendment to supplemental BLA 98-0737 -- STN103471. http://www.fda.gov/ downloads/Drugs/DevelopmentApprovalProcess/ HowDrugsareDevelopedandApproved/ ApprovalApplications/TherapeuticBiologicApplications/ ucm088275.pdf (accessed 17 Feb 2011).

\section{FDA 2002}

U.S. Food, Drug Administration. Interferon beta-1a (Rebif) Product Approval Information Licensing Action Approval Date: 3/7/2002. http:/ /www.fda.gov/Drugs/DevelopmentApprovalProcess/ HowDrugsareDevelopedandApproved/ ApprovalApplications/TherapeuticBiologicApplications/ ucm080737.htm

\section{FDA 2003}

U.S. Food, Drug Administration. Food and Drug Administration. Interferon beta-1a (AVONEX)Product Approval Information - Licensing Action 5/28/03. http: //www.fda.gov/Drugs/DevelopmentApprovalProcess/ HowDrugsareDevelopedandApproved/ ApprovalApplications/TherapeuticBiologicApplications/ ucm080469.htm.

\section{FDA 2004}

U.S. Food, Drug Administration. Tysabri (Natalizumab) Approval Date: 11/23/2004. http:/ /www.accessdata.fda.gov/drugsatfda docs/nda/2004/ 125104s000`Natalizumab.cfm.

\section{FDA 2005}

U.S. Food, Drug Administration. Mitoxantrone Hydrochloride (marketed as Novantrone and generics) - Healthcare Professional Sheet text version. http://www.fda.gov/Drugs/DrugSafety/ PostmarketDrugSafetyInformationforPatientsandProviders/ ucm126445.htm (accessed November 2011). 


\section{FDA 2011}

U.S. Food, Drug Administration. COPAXONE® (glatiramer acetate injection) solution for subcutaneous injection. http://www.fda.gov/downloads/Drugs/ GuidanceComplianceRegulatoryInformation/EnforcementActivitiesbyFDA/WarningLettersandNoticeofViolationLetterstoPharmaceuticalCompanies/UCM296204.pdf (accessed September 2012).

Filippini 2007

Filippini G, Ebers G. Multiple sclerosis: critical review of the evidence for each question. In: Candelise L, Hughes R, Liberati A, Uitdehaag BMJ, Warlow C editor(s). EvidenceBased Neurology. Management of neurological disorders. 1st Edition. Blackwell Publishing, 2007:221-33.

Fontoura 2010

Fontoura P. Monoclonal antibody therapy in multiple sclerosis: Paradigm shifts and emerging challenges. MAbs 2010;2(6):670-81.

Fox 2004

Fox E. Mechanism of action of mitoxantrone. Neurology 2004;63(12):S15-8.

Fragoso 2010

Fragoso Y, Frota E, Lopes J, Noal J, Giacomo M, Gomes $S$, et al.Severe depression, suicide attempts, and ideation during the use of interferon beta by patients with multiple sclerosis. Clinical Neuropharmacology 2010;33(6):312-6.

\section{Fragoso 2011}

Fragoso Y, Paggiaro M, Mastromauro R, da Silva Jacondino $\mathrm{G}$, Wilson $\mathrm{H}$. Literature systematic review on the ophthalmological side effects of interferons. Arquivos Brasileiros de Oftalmologia 2011;74(4):306-10.

\section{Glenny 2005}

Glenny A, Altman D, Song F, Sakarovitch C, Deeks J, D'Amico R, et al.Indirect comparisons of competing interventions. Health Technology Assessment 2005;9:1-34.

\section{Goodin 2002}

Goodin D, Frohman E, Garmany G, Halper J, Likosky W, Lublin F, et al.Disease modifying therapies in multiple sclerosis: report of the Therapeutics and Technology Assessment Subcommittee of the American Academy of Neurology and the MS Council for Clinical Practice Guidelines. Neurology 2002;58(2):169-78.

Goodman 2009

Goodman A, Rossman H, Bar-Or A, Miller A, Miller D, Schmierer K, et al.GLANCE: results of a phase 2, randomized, double-blind, placebo-controlled study. Neurology 2009;72(9):806-12.

Gray 2003

Gray O, McDonnell G, Forbes R. Intravenous immunoglobulins for multiple sclerosis. Cochrane Database of Systematic Reviews 2003, Issue Issue 3. Art. No.: CD002936. [DOI: 10.1002/14651858.CD002936]

\section{Gray 2004}

Gray O, McDonnell G, Forbes R. Methotrexate for multiple sclerosis. Cochrane Database of Systematic Reviews 2004, Issue 2. [DOI: 10.1002/14651858.CD003208.pub2]
Higgins 1996

Higgins J, Whitehead A. Borrowing strength from external trials in a meta-analysis. Statistics in Medicine 1996;15(24): 2733-49. [PUBMED: 8981683]

Higgins 2011

Higgins J, Green S (editors). Cochrane Handbook for Systematic Reviews of Interventions Version 5.1.0 [updated March 2011]. Available from www.cochrane-handbook.org. The Cochrane Collaboration, 2011.

\section{Johnston 2005}

Johnston A, Gudjonsson J, Sigmundsdottir H, Runar L, Valdimarsson H. The anti-inflammatory action of methotrexate is not mediated by lymphocyte apoptosis, but by the suppression of activation and adhesion molecules. Clinical Immunology 2005;114(2):154-63.

\section{Khoury 2010}

Khoury S, Healy B, Kivisäkk P, Viglietta V, Egorova S, Guttmann C, et al.A randomized controlled double-masked trial of albuterol add-on therapy in patients with multiple sclerosis. Archives of Neurology 2010;67(9):1055-61.

\section{Kremenchutzky 2006}

Kremenchutzky M, Rice G, Baskerville J, Wingerchuk D, Ebers G. The natural history of multiple sclerosis: a geographically based study. 9. Observations on the progressive phase of the disease. Brain 2006;129:584-94.

\section{Kurtzke 1983}

Kurtzke J. Rating neurologic impairment in multiple sclerosis: an expanded disability status scale (EDSS). Neurology 1983;33:1444-52.

\section{La Mantia 2007}

La Mantia L, Milanese C, Mascoli N, D'Amico R, Weinstock-Guttman B. Cyclophosphamide for multiple sclerosis. Cochrane Database of Systematic Reviews 2007, Issue Issue 1. Art. No.: CD002819. [DOI: 10.1002/ 14651858.CD002819.pub2]

\section{La Mantia 2010}

La Mantia L, Munari Luca M, Lovati R. Glatiramer acetate for multiple sclerosis. Cochrane Database of Systematic Reviews 2010, Issue 5. [DOI: 10.1002/ 14651858.CD004678]

\section{La Mantia 2012}

La Mantia L, Vacchi L, Di Pietrantonj C, Ebers G, Rovaris M, Fredrikson S, et al.Interferon beta for secondary progressive multiple sclerosis. Cochrane Database of Systematic Reviews 2012, Issue 1. [DOI: 10.1002/ 14651858.CD005181]

\section{Lalive 2011}

Lalive P, Neuhaus O, Benkhoucha M, Burger D, Hohlfeld $\mathrm{R}$, Zamvil S, et al.Glatiramer acetate in the treatment of multiple sclerosis: emerging concepts regarding its mechanism of action. CNS Drugs 2011;25(5):401-14.

\section{Le Page 2011}

Le Page E, Leray E, Edan G, French Mitoxantrone Safety Group. Long-term safety profile of mitoxantrone in a 
French cohort of 802 multiple sclerosis patients: a 5-year prospective study. Multiple Sclerosis 2011;17(7):867-75.

\section{Lu 2004}

$\mathrm{Lu}$ G, Ades A. Combination of direct and indirect evidence in mixed treatment comparisons. Statistics in Medicine 2004;23(20):3105-24.

Lu 2006

Lu G, Ades A. Assessing evidence inconsistency in mixed treatment comparisons. Journal of American Statistical Association 2006;101:447-59.

\section{Lublin 1996}

Lublin F, Reingold S. Defining the clinical course of multiple sclerosis: results of an international survey. National Multiple Sclerosis Society (USA) Advisory Committee on Clinical Trials of New Agents in Multiple Sclerosis. Neurology 1996;46:907-11.

\section{Martinelli 2005}

Martinelli B, Rovaris M, Capra R, Comi G. Mitoxantrone for multiple sclerosis. Cochrane Database of Systematic Reviews 2005, Issue 4 Art. No.: CD002127. [DOI: 10.1002/14651858.CD002127.pub2]

\section{McDonald 2001}

McDonald W, Compston A, Edan G, Goodkin D, Hartung $\mathrm{H}$, Lublin F. Recommended diagnostic criteria for multiple sclerosis: guidelines from the international panel on the diagnosis of multiple sclerosis. Annals of Neurology 2001; 50:121-7.

\section{Milo 2010}

Milo R, Kahana R. Multiple sclerosis: geoepidemiology, genetics and the environment. Autoimmune Reviews 2010;9 (5):A387-94.

\section{Nabavi 2011}

Nabavi S, Hamzehloo A, Shams J, Morsali D. Reversible therapy-related dysplastic hematopoiesis following beta interferon therapy in multiple sclerosis patients: report of 2 Cases. Iranian Journal of Neurology 2011;10(1-2):32-4.

Nakamura 2008

Nakamura Y, Kawachi Y, Furuta J, Otsuka F. Severe local skin reactions to interferon beta- $1 \mathrm{~b}$ in multiple sclerosisimprovement by deep subcutaneous injection. European Journal of Dermatology 2008;18(5):579-82.

Nonchev 2010

Nonchev B. Cases of interferon-alpha and interferon-betainduced thyroiditis. Folia Medica (Plovdiv) 2010;52(3): $5-12$.

Polman 2005

Polman C, Reingold S, Edan G, Filippi M, Hartung H, Kappos L, et al.Diagnostic criteria for multiple sclerosis: 2005 revisions to the 'McDonald Criteria'. Annals of Neurology 2005;58:840-6.

Poser 1983

Poser C, Paty D, Scheinberg L, McDonald W, Davis F, Ebers G, et al.New diagnostic criteria for multiple sclerosis: guidelines for research protocols. Annals of Neurology 1983; 13:227-31.

\section{Pozzilli 2004}

Pozzilli C, Marinelli F, Romano S, Bagnato F. Corticosteroids treatment. Journal of Neurological Sciences 2004;223(1): $47-51$.

\section{Pucci 2011}

Pucci E, Giuliani G, Solari A, Simi S, Minozzi S, Di Pietrantonj C, et al.Natalizumab for relapsing remitting multiple sclerosis. Cochrane Database of Systematic Reviews 2011, Issue 10. [DOI: 10.1002/14651858.CD007621]

\section{Ravnborg 2010}

Ravnborg M, Sørensen P, Andersson M, Celius E, Jongen P, Elovaara I, et al.Methylprednisolone in combination with interferon beta-1a for relapsing-remitting multiple sclerosis (MECOMBIN study): a multicentre, doubleblind, randomised, placebo-controlled, parallel-group trial. Lancet Neurology 2010;9:672-80.

Rice 2001

Rice G, Incorvaia B, Munari L, Ebers G, Polman C, D'Amico R, et al.Interferon in relapsing-remitting multiple sclerosis. Cochrane Database of Systematic Reviews 2001, Issue 4. [DOI: 10.1002/14651858.CD002002]

\section{Rojas 2010}

Rojas JI, Romano M, Ciapponi A, Patrucco L, Cristiano E. Interferon Beta for Primary Progressive Multiple Sclerosis. Cochrane Database of Systematic Reviews 2010, Issue 1. [DOI: 10.1002/14651858.CD006643]

\section{Salanti 2008}

Salanti G, Higgins J, Ades A, Ioannidis J. Evaluation of networks of randomized trials. Statistical Methods in Medical Research 2008;17:279-301.

\section{Salanti 2009}

Salanti G, Marinho V, Higgins J. A case study of multipletreatments meta-analysis demonstrates that covariates should be considered. Journal of Clinical Epidemiology 2009;62:857-64.

\section{Salanti 2011}

Salanti G, Ades A, Ioannidis J. Graphical methods and numerical summaries for presenting results from multipletreatment meta-analysis: an overview and tutorial. Journal of Clinical Epidemiology 2011;64:163-71.

\section{Schünemann 2011a}

Schünemann H, Oxman A, Higgins J, Vist G, Glasziou P, Guyatt G. Chapter 11: Presenting results and 'Summary of fi ndings' tables. In: Higgins JPT, Green $S$ (editors), Cochrane Handbook for Systematic Reviews of Interventions. The Cochrane Collaboration, 2011. Available from www.cochrane-handbook.org, Version 5.0.1 (updated March 2011).

\section{Schünemann 2011b}

Schünemann H, Oxman A, Vist G, Higgins J, Deeks J, Glasziou P, et al.Chapter 12: Interpreting results and drawing conclusions. In: Higgins JPT, Green S (editors). Cochrane Handbook for Systematic Reviews of Interventions. The Cochrane Collaboration, 2011. Available from 
www.cochrane-handbook.org, Version 5.1.0 (updated March 2011).

\section{Shirani 2012}

Shirani A, Zhao Y, Karim M, Evans C, Kingwell E, van der Kop M, et al.Association between use of interferon beta and progression of disability in patients with relapsingremitting multiple sclerosis. JAMA 2012;308(3):247-56. [: OTHER]

\section{Sloka 2005}

Sloka J, Stefanelli M. The mechanism of action of methylprednisolone in the treatment of multiple sclerosis. Multiple Sclerosis 2005;11:425-32.

\section{Smith 2010}

Smith B, Susan C, Rochelle F, Marian M, Tracy D, Benjamin K, et al.Drug class review: disease-modifying drugs for multiple sclerosis: final update 1 report [Internet]. Portland (OR): Oregon Health \& Science University, 2010. [: Available from: http://www.ncbi.nlm.nih.gov/books/ NBK50570/]

\section{Spiegelhalter 2002}

Spiegelhalter D, Best N, Carlin B, Van Der Linde A. Bayesian measures of model complexity and fit. Journal of the Royal Statistical Society 2002;64:583-616.

\section{Stangel 1999}

Stangel M, Toyka K, Gold R. Mechanisms of high-dose intravenous immunoglobulins in demyelinating diseases. Archives of Neurology 1999;56(6):661-3.
Tiede 2003

Tiede I, Fritz G, Strand S, Poppe D, Dvorsky R, Strand D, et al.CD28-dependent Rac1 activation is the molecular target of azathioprine in primary human CD4+ T lymphocytes. The Journal of Clinical Investigation 2003;111:1133-45. [PUBMED: 12697733]

\section{Vercellino 2009}

Vercellino M, Masera S, Lorenzatti M, Condello C, Merola A, Mattioda A, et al.Demyelination, in $\mathrm{fl}$ ammation and neurodegeneration in multiple sclerosis deep gray matter. Journal of Neuropathology and Experimental Neurology 2009;68:489-502.

\section{Weiner 1993}

Weiner H, Mackin G, Matsui M, Orav E, Khoury S, Dawson D, et al.Double-blind pilot trial of oral tolerization with myelin antigens in multiple sclerosis. Science 1993;259 (5099):1321-4.

\section{Yousry 2006}

Yousry T, Major E, Ryschkewitsch C, Fahle G, Fischer S, Hou J, et al.Evaluation of patients treated with natalizumab for progressive multifocal leukoencephalopathy. The New England Journal of Medicine 2006;354(9):924-33. [PUBMED: 16510746]

Zintzaras 2012

Zintzaras E, Doxani C, Mprotsis T, Schmid CH, Hadjigeorgiou G. Network analysis of randomized controlled trials in multiple sclerosis. Clinical Therapeutics 2012;34(4):857-69.

* Indicates the major publication for the study 


\section{CHARACTERISTICS OF STUDIES}

\section{Characteristics of included studies [ordered by study ID]}

\section{Achiron 1998}

\begin{tabular}{ll}
\hline Methods & RCT \\
\hline Participants & Age: $19-60$ years; definite RRMS; mean disease duration 4 years; mean EDSS 3.0 \\
\hline Interventions & $\begin{array}{l}\text { Loading dose of intravenous immunoglobulins } 0.4 \mathrm{~g} / \mathrm{kg} / \text { body weight per day for } 5 \\
\text { consecutive days followed by additional booster doses of intravenous immunoglobulins } \\
0.4 \mathrm{~g} / \mathrm{kg} / \text { body weight once daily every } 2 \text { months for } 2 \text { years }(\mathrm{n} 20) \\
\text { placebo consisting of } 0.9 \% \text { saline administered with the same schedule as the active } \\
\text { treatment }(\mathrm{n} 20)\end{array}$ \\
\hline Outcomes & Relapses at 12 and 24 months. Progression at 24 months \\
\hline Notes & Funding: Miles Inc. Cutter Biological, Bayer and Promedico \\
\hline
\end{tabular}

\section{Risk of bias}

\begin{tabular}{|c|c|c|}
\hline Bias & Authors' judgement & Support for judgement \\
\hline $\begin{array}{l}\text { Random sequence generation (selection } \\
\text { bias) }\end{array}$ & Unclear risk & $\begin{array}{l}\text { Patients were assigned to receive immunoglobulin or placebo } \\
\text { by a block-stratified randomisation procedure, performed at the } \\
\text { pharmacy }\end{array}$ \\
\hline Allocation concealment (selection bias) & Low risk & $\begin{array}{l}\text { Allocation made in pharmacy. Bottle of immunoglobulin or } \\
\text { placebo were wrapped in sealed opaque bags and brought to the } \\
\text { patients' rooms. Use also of an opaque plastic bag for fluid }\end{array}$ \\
\hline $\begin{array}{l}\text { Blinding of participants and personnel } \\
\text { (performance bias) } \\
\text { All outcomes }\end{array}$ & Low risk & $\begin{array}{l}\text { "All patients and evaluators were blinded to treatment...the bottles } \\
\text { of immunoglobulin or placebo were wrapped in sealed opaque bags } \\
\text { and brought to the patients' rooms. The entire IV set was covered by } \\
\text { an opaque plastic bag to ensure that any possible fluid turbidity or } \\
\text { frothing would not be evident to the investigators or patients". Page } \\
399\end{array}$ \\
\hline $\begin{array}{l}\text { Blinding of outcome assessment (detection } \\
\text { bias) } \\
\text { All outcomes }\end{array}$ & Low risk & "All patients and evaluators were blinded to treatment". Page 399 \\
\hline $\begin{array}{l}\text { Incomplete outcome data (attrition bias) } \\
\text { All outcomes }\end{array}$ & Low risk & $\begin{array}{l}\text { "Two patients discontinued treatment after the firstyear (one in each } \\
\text { group)." Page } 400 \text {. The intention-to-treat analysis was performed } \\
\text { including the } 2 \text { withdrawals }\end{array}$ \\
\hline Selective reporting (reporting bias) & Low risk & The published reports included all expected efficacy outcomes \\
\hline
\end{tabular}


Achiron 1998 (Continued)

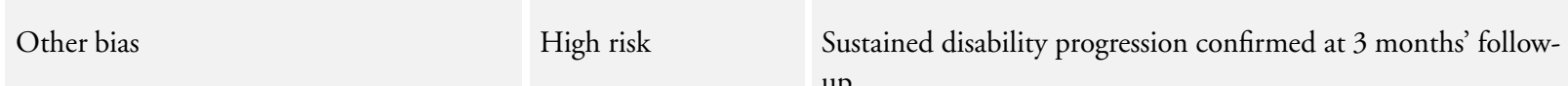

up

\section{AFFIRM 2006}

\begin{tabular}{ll}
\hline Methods & RCT \\
\hline Participants & $\begin{array}{l}\text { Age: } 18-50 \text { years; clinical definite RRMS; disease duration } 0-33 \text { years; EDSS 0-5.0; } \geq 1 \\
\text { relapses in the year before randomisation }\end{array}$ \\
\hline
\end{tabular}

Interventions

Natalizumab $300 \mathrm{mg}$ by intravenous infusion every 4 weeks for up to 116 weeks (n. 627)

Placebo (unspecified) (n. 315)

Outcomes

Relapses at 12 and 24 months. Progression at 24 months.

Notes

Funding: Biogen Idec, Inc. and Elan Pharmaceutical.

\section{Risk of bias}

Bias

Random sequence generation (selection Low risk bias)
Authors' judgement Support for judgement

"Patients were randomly assigned to treatment that was stratified according to study site in blocks of three (two active, one placebo) with the use of a computer-generated block randomization schedule.

" Page 900

Allocation concealment (selection bias) Low risk

"A multidigit identification number, implemented by an interactive voice-response system was used." Page 900

Blinding of participants and personnel Low risk (performance bias)

All outcomes

"All study personnel, patients, sponsor personnel involved in the conduct of the study, and the investigator advisory committee were unaware of treatment assignments throughout the study (Page 900)

... Treating neurologists were responsible for all aspects of patient care, including the management of adverse events and the treatment of relapsing disease." Page 901

Blinding of outcome assessment (detection Low risk bias)

All outcomes

"Examining neurologists performed objective evaluation with use of the EDSS and neurologic examination during all study visits; they were not in contact with patients in any other capacity, so as to reduce the possibility of being unblinded by side effects or laboratory assessments." Page 901

Incomplete outcome data (attrition bias) Low risk All outcomes

" $8 \%$ of patients in the natalizumabgroup and 10\% of those in the placebo group withdrew from the study". Pages 902-903 


\section{AFFIRM 2006 (Continued)}

\begin{tabular}{|c|c|c|}
\hline Selective reporting (reporting bias) & High risk & $\begin{array}{l}\text { The number of patients who progressed at } 2 \text { years were not } \\
\text { available }\end{array}$ \\
\hline Other bias & High risk & $\begin{array}{l}\text { Data analysis performed by Biogen Idec and Elan Pharmaceu- } \\
\text { ticals. Sustained disability progression confirmed at } 3 \text { months' } \\
\text { follow-up. Relapses assessed also as adverse events. The number } \\
\text { of lost to follow-up at } 1 \text { year were not available }\end{array}$ \\
\hline
\end{tabular}

\section{Andersen 2004}

\begin{tabular}{ll}
\hline Methods & RCT \\
\hline Participants & $\begin{array}{l}\text { Age: } 18-65 \text { years; clinical definite SPMS defined as } \geq 1 \text { EDSS point increase in } 4 \text { years } \\
\text { before randomisation, with or without superimposed exacerbations; EDSS }<7.0\end{array}$ \\
\hline Interventions & $\begin{array}{l}\text { IFNß-1a (Rebif) } 22 \mu \mathrm{g} \text { subcutaneously weekly for } 36 \text { months (n. 188) } \\
\text { Placebo (unspecified) }(\mathrm{n} .183)\end{array}$ \\
\hline Outcomes & Relapses at 36 months. Progression at 36 months \\
\hline Notes & Funding: Serono International, Geneva, Switzerland
\end{tabular}

\section{Risk of bias}

\begin{tabular}{|c|c|c|}
\hline Bias & Authors' judgement & Support for judgement \\
\hline $\begin{array}{l}\text { Random sequence generation (selection } \\
\text { bias) }\end{array}$ & Unclear risk & Not described \\
\hline Allocation concealment (selection bias) & Unclear risk & “equal allocation.” Page 707 \\
\hline $\begin{array}{l}\text { Blinding of participants and personnel } \\
\text { (performance bias) } \\
\text { All outcomes }\end{array}$ & Unclear risk & "Patients were instructed to cover injection sites." Page 707 \\
\hline $\begin{array}{l}\text { Blinding of outcome assessment (detection } \\
\text { bias) } \\
\text { All outcomes }\end{array}$ & Unclear risk & $\begin{array}{l}\text { "Neurologists blinded to dose assignment were responsible for neu- } \\
\text { rological assessments". Page } 707\end{array}$ \\
\hline $\begin{array}{l}\text { Incomplete outcome data (attrition bias) } \\
\text { All outcomes }\end{array}$ & High risk & $\begin{array}{l}\text { The study had ended prematurely due to negative results from } \\
\text { SPECTRIMS study. Only } 83 \% \text { of randomised patients com- } \\
\text { pleted about } 3 \text { years. Losses to follow-up not included in anal- } \\
\text { ysis: treatment } 21 \% \text {; placebo } 16 \% \text {. More AE and patients' de- } \\
\text { cision in the treated group. The median time on treatment was } \\
35.2 \text { months (mean } 32.0 \text { ) for placebo and } 35.0 \text { months (mean } \\
31.1 \text { ) for IFNß-1a }\end{array}$ \\
\hline Selective reporting (reporting bias) & Low risk & The published reports included all expected efficacy outcomes \\
\hline
\end{tabular}


Andersen 2004 (Continued)

\begin{tabular}{l|l|l}
\hline Other bias & Low risk & The study appears to be free of other sources of bias
\end{tabular}

BEYOND 2009

\begin{tabular}{ll}
\hline Methods & RCT \\
\hline Participants & $\begin{array}{l}\text { Age: } 18-55 \text { years; clinical or laboratory-supported definite RRMS; EDSS 0-5; disease } \\
\text { duration } 3-8 \text { years; } \geq 1 \text { relapses in the year before randomisation }\end{array}$ \\
\hline Interventions & $\begin{array}{l}\text { IFNß-1b } 250 \mu \mathrm{g} \text { subcutaneous every other day (n. 897) } \\
\text { IFNß-1b } 500 \mu \mathrm{g} \text { subcutaneous every other day (n. 899) } \\
\text { glatiramer acetate } 20 \text { mg subcutaneous every day (n. 448) }\end{array}$ \\
\hline Outcomes & Relapses at 24 months. Progression at 24 months \\
\hline Notes & Funding: Bayer HealthCare Pharmaceuticals \\
\hline
\end{tabular}

\section{Risk of bias}

Bias

Random sequence generation (selection Low risk bias)

Allocation concealment (selection bias) Low risk

Blinding of participants and personnel High risk (performance bias)

All outcomes

All outcomes

Blinding of outcome assessment (detection Low risk bias)

All outcomes

\section{Authors' judgement Support for judgement}

"Use of SAS-based block randomisation with regional stratification". Page 890

"Patients were randomly assigned in a 2:2:1 ratio ... by the central
randomisation group..." Page 890

"Physicians and patients were double-blind to comparisons between the two doses of IFN $\beta-1 b .$. Ibuprofen or acetaminophen were given at the same time as random assignment to IFN $\beta-1 b$, at least during the fir $r$ st 3 months, to

reduce fl $u$-like symptoms. The treating physicians and the patients were therefore aware of treatment assignments". Page 891

“ The masked evaluating physicians did all neurological assessments and ascertained functional system and EDSS scores... The evaluating physicians were not involved in the care of patients and had no access to patient $\mathrm{fi}$ les or previous

assessments. ... Patients covered their injection sites during neurological examination and did not discuss any adverse events with the evaluating physician”. Page 891-2

Incomplete outcome data (attrition bias) High risk All outcomes

Losses to follow-up not included in analysis: $500 \mu \mathrm{g}$ IFNß-1b 13\%; $250 \mu \mathrm{g}$ IFNß-1b 20\%; glatiramer acetate 16\%

Selective reporting (reporting bias) Low risk
The published reports included all expected efficacy outcomes 
BEYOND 2009 (Continued) \begin{tabular}{lll}
\hline Other bias & High risk & $\begin{array}{l}\text { Sustained disability progression confirmed at } 3 \text { months' follow- } \\
\text { up }\end{array}$
\end{tabular}

Bornstein 1987

\begin{tabular}{|c|c|c|}
\hline Methods & \multicolumn{2}{|l|}{ RCT } \\
\hline Participants & \multicolumn{2}{|c|}{$\begin{array}{l}\text { Age: } 20 \text { - } 35 \text { years; definite RRMS; EDSS } 0-6.0 \text {; disease duration } \geq 1 \text { year; at least } 2 \\
\text { relapses in the } 2 \text { years before randomisation }\end{array}$} \\
\hline Interventions & \multicolumn{2}{|c|}{$\begin{array}{l}\text { Glatiramer acetate } 20 \mathrm{mg} \text { subcutaneous every day (n. 25) } \\
\text { Placebo bacteriostatic saline subcutaneous every day (n. 25) }\end{array}$} \\
\hline Outcomes & \multicolumn{2}{|c|}{ Relapses at 12 and 24 months. Progression at 24 months } \\
\hline Notes & \multicolumn{2}{|c|}{ Funding: Grants from the NINCDS and the NIH, Bethesda, Md. } \\
\hline \multicolumn{3}{|l|}{ Risk of bias } \\
\hline Bias & Authors' judgement & Support for judgement \\
\hline $\begin{array}{l}\text { Random sequence generation (selection } \\
\text { bias) }\end{array}$ & High risk & $\begin{array}{l}\text { "The random assignment of the first patient of a pair determined } \\
\text { the assignment of both". Page } 409\end{array}$ \\
\hline Allocation concealment (selection bias) & High risk & $\begin{array}{l}\text { An open allocation schedule was used: "Treatment assignments } \\
\text { were made known to the clinical assistant responsible for the pro- } \\
\text { duction, labelling and distribution of medication". Page } 409\end{array}$ \\
\hline $\begin{array}{l}\text { Blinding of participants and personnel } \\
\text { (performance bias) } \\
\text { All outcomes }\end{array}$ & High risk & $\begin{array}{l}\text { "The patient's self evaluation of ... side effects were reported to the } \\
\text { clinical assistant, how was not blinded to the treatment". Page } 409\end{array}$ \\
\hline $\begin{array}{l}\text { Blinding of outcome assessment (detection } \\
\text { bias) } \\
\text { All outcomes }\end{array}$ & Low risk & $\begin{array}{l}\text { "A neurologist unaware of the patient's treatment group completed } \\
\text { a neurologic examination and status evaluation". Page } 409\end{array}$ \\
\hline $\begin{array}{l}\text { Incomplete outcome data (attrition bias) } \\
\text { All outcomes }\end{array}$ & Low risk & $\begin{array}{l}\text { Losses to follow-up excluded from the study analysis: } 2 \text { of } 25 \\
\text { placebo patients }\end{array}$ \\
\hline Selective reporting (reporting bias) & Low risk & $\begin{array}{l}\text { The published reports included all expected efficacy outcomes } \\
\text { and those outcomes that were pre-specifi ed in the methods sec- } \\
\text { tion }\end{array}$ \\
\hline Other bias & High risk & $\begin{array}{l}\text { Sustained disability progression was confirmed at } 3 \text { months' fol- } \\
\text { low-up }\end{array}$ \\
\hline
\end{tabular}


Bornstein 1991

\begin{tabular}{ll}
\hline Methods & RCT \\
\hline Participants & $\begin{array}{l}\text { Age: } 20-60 \text { years; progressive MS; EDSS 2-6.5; progression } \geq 18 \text { months; } \leq 2 \text { relapses } \\
\text { in the } 2 \text { years before randomisation }\end{array}$ \\
\hline Interventions & $\begin{array}{l}\text { glatiramer acetate } 30 \text { mg subcutaneous twice a day (n. 51) } \\
\text { placebo, saline alone, subcutaneous twice a day (n. 55) }\end{array}$ \\
\hline Outcomes & Progression at 24 months \\
\hline Notes & Funding: Grants from the NINCDS and the NIH, Bethesda, Md. \\
\hline
\end{tabular}

\section{Risk of bias}

Bias

Random sequence generation (selection Low risk bias)

Allocation concealment (selection bias) Unclear risk

Blinding of participants and personnel Unclear risk (performance bias)

All outcomes

Blinding of outcome assessment (detection Low risk bias)

All outcomes

Incomplete outcome data (attrition bias) Low risk All outcomes

Selective reporting (reporting bias) Low risk

Other bias

\section{Support for judgement}

"... by randomized block design with two baseline EDSS strata < 5.0 and 5.0 or greater" Page 534

"The investigator notified the statistical center, which assigned a randomization code number. Shipment of glatiramer acetate to the patients at their individual centers were totally at random and were dictated by the patients' date of entry into the trial. Only the statistician and the clinical assistant at Albert Einstein College of Medicine, who distributed medication, were aware of patients assignments". Page 534

"Side effects were reported to a clinical assistant". Page 534

\begin{tabular}{|c|c|c|}
\hline 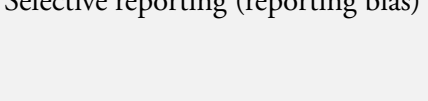 & Len $110 \mathrm{n}$ & $\begin{array}{l}\text { and those outcomes that were pre-specifi ed in the methods sec- } \\
\text { tion }\end{array}$ \\
\hline Other bias & High risk & $\begin{array}{l}\text { Sustained disability progression was confirmed at } 3 \text { months' fol- } \\
\text { low-up }\end{array}$ \\
\hline
\end{tabular}




\begin{tabular}{|c|c|c|}
\hline Methods & \multicolumn{2}{|l|}{ RCT } \\
\hline Participants & \multicolumn{2}{|c|}{$\begin{array}{l}\text { Mean age: } 35 \text { years; clinical definite RRMS; EDSS }<5.5 \text {; disease duration: not reported; } \\
\text { no relapses in the previous } 45 \text { days before randomisation }\end{array}$} \\
\hline Interventions & \multicolumn{2}{|c|}{$\begin{array}{l}\text { Intravenous methylprednisolone } 2 \mathrm{~g} \text { in saline solution for } 12 \text { hours, every } 45-60 \text { days } \\
\text { for two years or until relapse (n. 17) } \\
\text { Placebo i.v. saline solution at the same schedule (n. 19) }\end{array}$} \\
\hline Outcomes & \multicolumn{2}{|c|}{ Relapses at 12 and 24 months } \\
\hline Notes & \multicolumn{2}{|l|}{ Funding: None } \\
\hline \multicolumn{3}{|l|}{ Risk of bias } \\
\hline Bias & Authors' judgement & Support for judgement \\
\hline $\begin{array}{l}\text { Random sequence generation (selection } \\
\text { bias) }\end{array}$ & Unclear risk & "The method of randomisation was centralised" (Cochrane review) \\
\hline Allocation concealment (selection bias) & Low risk & $\begin{array}{l}\text { "Allocation were generated by computer by personnel not involved } \\
\text { in patients management" (Cochrane review) }\end{array}$ \\
\hline $\begin{array}{l}\text { Blinding of participants and personnel } \\
\text { (performance bias) } \\
\text { All outcomes }\end{array}$ & Unclear risk & "the study was double blind" (Cochrane review) \\
\hline $\begin{array}{l}\text { Blinding of outcome assessment (detection } \\
\text { bias) } \\
\text { All outcomes }\end{array}$ & Unclear risk & "the study was double blind" (Cochrane review) \\
\hline $\begin{array}{l}\text { Incomplete outcome data (attrition bias) } \\
\text { All outcomes }\end{array}$ & High risk & $\begin{array}{l}\text { "There were } 10 \text { patients ( } 7 \text { treated) lost to follow-up ( } 28 \% \text { overall). } \\
\text { Moreover, patients experiencing an exacerbation were not followed } \\
\text { up although a two year follow-up was planned". (Cochrane review) }\end{array}$ \\
\hline Selective reporting (reporting bias) & High risk & $\begin{array}{l}\text { "Patients were not followed-up after the first exacerbation, contrary } \\
\text { to what was planned. Since patients not experiencing a relapse in } \\
\text { the two years of the study were just 2, we did not have any data on } \\
\text { disability progression for the majority of the patients". (Cochrane } \\
\text { review) }\end{array}$ \\
\hline Other bias & High risk & $\begin{array}{l}\text { "Prematurely interrupted at } 36 \text { out of } 72 \text { planned patients for or- } \\
\text { ganisational reasons and lack of funding". (Cochrane review) }\end{array}$ \\
\hline
\end{tabular}


British and Dutch 1988

\begin{tabular}{ll}
\hline Methods & RCT \\
\hline Participants & $\begin{array}{l}\text { Age: } 30-65 \text { years; definite RRMS, SPMS or PPMS; disease duration 5-15 years; EDSS } \\
2.5-6.5 ; \leq 1 \text { relapses in the 2 years before randomisation }\end{array}$ \\
\hline Interventions & $\begin{array}{l}\text { Azathioprine } 2.5 \mathrm{mg} / \mathrm{Kg} \text { body weight oral daily (n. 174) } \\
\text { Placebo (n. 180) }\end{array}$ \\
\hline Outcomes & Relapses at 12,24 and 36 months \\
\hline Notes & Funding: Wellcome Company \\
\hline
\end{tabular}

\section{Risk of bias}

\begin{tabular}{|c|c|c|}
\hline Bias & Authors' judgement & Support for judgement \\
\hline $\begin{array}{l}\text { Random sequence generation (selection } \\
\text { bias) }\end{array}$ & Low risk & $\begin{array}{l}\text { The randomisation sequence was generated for each centre by } \\
\text { the trial statistician "by randomized block design". Page } 534\end{array}$ \\
\hline Allocation concealment (selection bias) & Low risk & $\begin{array}{l}\text { "The investigator notified the statistical center, which assigned a } \\
\text { randomization code number" Page } 534 \text {. The packs of trial tablets } \\
\text { were issued to individual pharmacies labelled with a code. The } \\
\text { treatment and placebo tablets were identical }\end{array}$ \\
\hline
\end{tabular}

Blinding of participants and personnel Low risk (performance bias)

Patients were blind to treatment.

All outcomes

Blinding of outcome assessment (detection Low risk bias)

All outcomes

Incomplete outcome data (attrition bias) Low risk
All outcomes

\begin{tabular}{|c|c|c|}
\hline Selective reporting (reporting bias) & High risk & $\begin{array}{l}\text { Proportion of participants who progressed at } 2 \text { years was not } \\
\text { available }\end{array}$ \\
\hline Other bias & High risk & $\begin{array}{l}\text { Sustained disability progression confirmed at } 3 \text { months' follow- } \\
\text { up }\end{array}$ \\
\hline
\end{tabular}

\section{CCMSSG 1991}

\begin{tabular}{ll}
\hline Methods & RCT \\
\hline Participants & Mean age: 32 years; clinically or laboratory-supported SPMS, PPMS or PRMS; $\geq 1.0$ \\
& EDSS in the year before randomisation; mean disease duration 10 years; mean EDSS 5. \\
& $8(0.6)$
\end{tabular}

Immunomodulators and immunosuppressants for multiple sclerosis: a network meta-analysis (Review)
A masked assessor recorded the number of relapses, the ambulatory index and the Kurtzke scale

Losses to follow-up not included in the study analysis (at the end of the study): Treatment arm $8 \%$; placebo $6 \%$

Proportion of participants who progressed at 2 years was not Sustained disability progression confirmed at 3 months' follow- 


\section{CCMSSG 1991 (Continued)}

\begin{tabular}{|c|c|c|}
\hline Interventions & \multicolumn{2}{|c|}{$\begin{array}{l}\text { Cyclophosphamide } 1 \mathrm{~g} \text { intravenous three times weekly }+40 \mathrm{mg} \text { prednisone tapered for } \\
16 \text { days (total dose } \leq 9 \mathrm{gm}) \text { (n. } 55) \\
\text { Placebo (n. } 56)\end{array}$} \\
\hline Outcomes & \multicolumn{2}{|c|}{ Progression at 36 months } \\
\hline Notes & \multicolumn{2}{|c|}{ Funding: BRISTOL Myers; Upjohn } \\
\hline \multicolumn{3}{|l|}{ Risk of bias } \\
\hline Bias & Authors' judgement & Support for judgement \\
\hline $\begin{array}{l}\text { Random sequence generation (selection } \\
\text { bias) }\end{array}$ & Unclear risk & $\begin{array}{l}\text { "A randomisation sequence was generated separately for each centre. } \\
\text { Patients were stratified by centre and EDSS score." Page } 442\end{array}$ \\
\hline Allocation concealment (selection bias) & Unclear risk & Not described. \\
\hline $\begin{array}{l}\text { Blinding of participants and personnel } \\
\text { (performance bias) } \\
\text { All outcomes }\end{array}$ & High risk & $\begin{array}{l}\text { "Patients with exacerbation or progression were seen by the mon- } \\
\text { itoring neurologist... who was aware of the treatment allocation". } \\
\text { Pages } 442,444\end{array}$ \\
\hline $\begin{array}{l}\text { Blinding of outcome assessment (detection } \\
\text { bias) } \\
\text { All outcomes }\end{array}$ & Low risk & $\begin{array}{l}\text { "The evaluating neurologist (not involved with the patients' ongoing } \\
\text { care) was blinded". Page } 444\end{array}$ \\
\hline $\begin{array}{l}\text { Incomplete outcome data (attrition bias) } \\
\text { All outcomes }\end{array}$ & Low risk & $\begin{array}{l}\text { "Subjects who did not complete the allocated treatment were followed } \\
\text { and their outcome was assigned to the group to which they were } \\
\text { randomised (intention to treat analysis)". Page } 443\end{array}$ \\
\hline Selective reporting (reporting bias) & Low risk & $\begin{array}{l}\text { The published reports included patients who progressed at } 36 \\
\text { months }\end{array}$ \\
\hline Other bias & High risk & $\begin{array}{l}\text { Sustained disability progression confirmed at } 3 \text { months' follow- } \\
\text { up }\end{array}$ \\
\hline
\end{tabular}

Comi 2001

Methods RCT

Participants

Age: 18-50 years; clinical or laboratory-supported definite RRMS; EDSS 0-5.0; disease duration $\geq 1$ years; $\geq 1$ relapses in the 2 years before randomisation

Interventions

Glatiramer acetate $20 \mathrm{mg}$ subcutaneous every day (n. 119)

Placebo (not described) (n. 120)

Outcomes

Relapses at 9 months 


\section{Comi 2001 (Continued)}

\begin{tabular}{|c|c|c|}
\hline Notes & \multicolumn{2}{|c|}{ Funding: Teva Pharmaceutical } \\
\hline \multicolumn{3}{|l|}{ Risk of bias } \\
\hline Bias & Authors' judgement & Support for judgement \\
\hline $\begin{array}{l}\text { Random sequence generation (selection } \\
\text { bias) }\end{array}$ & Low risk & $\begin{array}{l}\text { "The randomization list, stratified by centers, was computer-gen- } \\
\text { erated by the TEVA Statistical Data Management Department. } \\
\text { Equal allocation of the two treatment groups was used". Page } 291\end{array}$ \\
\hline Allocation concealment (selection bias) & Unclear risk & Not described \\
\hline $\begin{array}{l}\text { Blinding of participants and personnel } \\
\text { (performance bias) } \\
\text { All outcomes }\end{array}$ & Unclear risk & $\begin{array}{l}\text { "A treating neurologist was responsible for the overall medical man- } \\
\text { agement of the patient including safety monitoring... All personnel } \\
\text { were unaware of treatment allocation... both the treating neurologist } \\
\text { and the patient were informed on the importance of not discussing } \\
\text { safety issue with the examining neurologist". Page } 291\end{array}$ \\
\hline $\begin{array}{l}\text { Blinding of outcome assessment (detection } \\
\text { bias) } \\
\text { All outcomes }\end{array}$ & Unclear risk & $\begin{array}{l}\text { "An examining neurologist was responsible for all scheduled neu- } \\
\text { rological examinations and exacerbation follow-up". Page } 291\end{array}$ \\
\hline $\begin{array}{l}\text { Incomplete outcome data (attrition bias) } \\
\text { All outcomes }\end{array}$ & Low risk & $\begin{array}{l}\text { "Analyses were based on an intention to treat dataset. The last } \\
\text { observation carried forward (LOCF) method was implemented to } \\
\text { account for early discontinuation and missing data. " } 7 \text { (6\%) pa- } \\
\text { tients dropped out in each arm". Page } 292\end{array}$ \\
\hline Selective reporting (reporting bias) & High risk & Progression was not measured in the trial. \\
\hline Other bias & High risk & Teva Pharmaceutical was involved in the trial. \\
\hline
\end{tabular}

Edan 1997

\begin{tabular}{ll}
\hline Methods & RCT \\
\hline Participants & $\begin{array}{l}\text { Age: } 18-45 \text { years; definite SPMS or PRMS; disease duration }<10 \text { years; } \geq 2 \text { relapses or } \\
\geq 2 \text { EDSS points increase in the year before randomisation; EDSS } \leq 6.0\end{array}$ \\
\hline Interventions & $\begin{array}{l}20 \text { mg intravenously/month and methylprednisolone }(1 \mathrm{~g} \text { intravenously/month) (n. 21) } \\
\text { methylprednisolone alone }(1 \mathrm{~g} \text { intravenously/month) }(\mathrm{n} . \text {. 21) }\end{array}$ \\
\hline Outcomes & Relapses at 6 months. \\
\hline Notes & Funding: not reported \\
\hline
\end{tabular}

\section{Risk of bias}


Edan 1997 (Continued)

\begin{tabular}{|c|c|c|}
\hline Bias & Authors' judgement & Support for judgement \\
\hline $\begin{array}{l}\text { Random sequence generation (selection } \\
\text { bias) }\end{array}$ & Unclear risk & Not described \\
\hline Allocation concealment (selection bias) & Low risk & $\begin{array}{l}\text { "The allocation of the treatment was done after inclusion by a central } \\
\text { randomisation service by fax". Page } 113\end{array}$ \\
\hline $\begin{array}{l}\text { Blinding of participants and personnel } \\
\text { (performance bias) } \\
\text { All outcomes }\end{array}$ & High risk & $\begin{array}{l}\text { "In the present study, ... neither the patients nor the clinical inves- } \\
\text { tigators were blinded during the study. Blinding of patients was not } \\
\text { possible in this trial, as obvious side effects of mitoxantrone were } \\
\text { experienced in almost all cases. Blinding of the physician was made } \\
\text { difficult by the fall in white cell count that always accompanies mi- } \\
\text { toxantrone treatment". Page } 116\end{array}$ \\
\hline $\begin{array}{l}\text { Blinding of outcome assessment (detection } \\
\text { bias) } \\
\text { All outcomes }\end{array}$ & High risk & $\begin{array}{l}\text { "Blind clinical observers might have been appointed, but this could } \\
\text { not be done for economic reasons". Page } 116\end{array}$ \\
\hline $\begin{array}{l}\text { Incomplete outcome data (attrition bias) } \\
\text { All outcomes }\end{array}$ & Low risk & $\begin{array}{l}5 \text { withdrawals "due to pronounced clinical worsening" (all in the } \\
\text { methylprednisolone group) were included in analysis }\end{array}$ \\
\hline Selective reporting (reporting bias) & Low risk & The published reports included all expected efficacy outcomes \\
\hline Other bias & High risk & $\begin{array}{l}\text { Sustained disability progression confirmed at } 2 \text { months' follow- } \\
\text { up. It's unclear if this study was sponsored }\end{array}$ \\
\hline
\end{tabular}

Ellison 1989

\begin{tabular}{|c|c|}
\hline Methods & RCT \\
\hline Participants & $\begin{array}{l}\text { Mean age: } 32 \text { years; definite SPMS or PPMS; disease duration 5-15 years; EDSS 2.5-6. } \\
5 ; \leq 1 \text { relapses in the } 2 \text { years before randomisation }\end{array}$ \\
\hline Interventions & $\begin{array}{l}\text { Azathioprine } 3 \mathrm{mg} / \mathrm{kg} \text { body weight oral daily (n. } 31 \text { ) } \\
\text { Azathioprine } 3 \mathrm{mg} / \mathrm{kg} \text { body weight oral daily and methylprednisolone for } 36 \text { weeks (n. } \\
\text { 34) } \\
\text { Placebo (n. 34) }\end{array}$ \\
\hline Outcomes & Relapses at 12, 24 and 36 months. Progression at 36 months \\
\hline Notes & Funding: Wellcome Company and Upjohn Company \\
\hline
\end{tabular}

\section{Risk of bias}

Bias

Authors' judgement Support for judgement 


\section{Ellison 1989 (Continued)}

\begin{tabular}{|c|c|c|}
\hline $\begin{array}{l}\text { Random sequence generation (selection } \\
\text { bias) }\end{array}$ & Unclear risk & $\begin{array}{l}\text { "Patient sequence was the order of presenting the initial prescription } \\
\text { to the pharmacy". Page } 1019\end{array}$ \\
\hline Allocation concealment (selection bias) & Unclear risk & $\begin{array}{l}\text { "The statistician told the examining neurologists that the treatments } \\
\text { would be allocated by a randomisation process to blocks of } 4 \text { successive } \\
\text { patients, but the assignment rules were not revealed". Page } 1019\end{array}$ \\
\hline $\begin{array}{l}\text { Blinding of participants and personnel } \\
\text { (performance bias) } \\
\text { All outcomes }\end{array}$ & Low risk & $\begin{array}{l}\text { "Monitoring neurologist, study nurse, clinic coordinator, technician } \\
\text { and patients were masked to the treatment assigned". Page } 1019\end{array}$ \\
\hline $\begin{array}{l}\text { Blinding of outcome assessment (detection } \\
\text { bias) } \\
\text { All outcomes }\end{array}$ & Low risk & $\begin{array}{l}\text { “Observer neurologist was masked to the treatment assigned”. Page } \\
1019\end{array}$ \\
\hline $\begin{array}{l}\text { Incomplete outcome data (attrition bias) } \\
\text { All outcomes }\end{array}$ & Low risk & $\begin{array}{l}\text { No losses to follow-up at } 1 \text { year; } 2 \text { placebo and } 1 \text { methylpred- } \\
\text { nisolone+ azathioprine arm at } 2 \text { years; } 6 \text { placebo, } 5 \text { azathioprine } \\
\text { and } 6 \text { methylprednisolone+ azathioprine at } 3 \text { years }\end{array}$ \\
\hline Selective reporting (reporting bias) & Low risk & Primary outcomes of interest were reported completely. \\
\hline Other bias & High risk & $\begin{array}{l}\text { Sustained disability progression confirmed at } 3 \text { months' follow- } \\
\text { up }\end{array}$ \\
\hline
\end{tabular}

Etemadifar 2006

\begin{tabular}{ll}
\hline Methods & RCT \\
\hline Participants & $\begin{array}{l}\text { Age: } 15-50 \text { years; clinical or laboratory-supported definite RRMS; mean disease duration } \\
\text { 3 years; EDSS } \leq 5.0 ; \geq 2 \text { relapses in the } 2 \text { years before randomisation }\end{array}$ \\
\hline Interventions & IFNß-1b $250 \mu \mathrm{g}$ subcutaneous every other day for 24 months (n. 30) \\
& $\begin{array}{l}\text { IFNß-1a (Avonex) } 30 \mu \mathrm{g} \text { intramuscular once a week for 24 months (n. 30) } \\
\text { IFNß-1a (Rebif) } 44 \mu \mathrm{g} \text { subcutaneous three times a week for 24 months (n. 30) }\end{array}$ \\
\hline Outcomes & Relapses at 24 months \\
\hline Notes & Funding: not reported \\
\hline
\end{tabular}

\section{Risk of bias}

\begin{tabular}{|c|c|c|}
\hline Bias & Authors' judgement & Support for judgement \\
\hline $\begin{array}{l}\text { Random sequence generation (selection } \\
\text { bias) }\end{array}$ & Unclear risk & $\begin{array}{l}\text { Patients "were assigned randomly and equally to one of the three } \\
\text { treatment groups". Page } 284\end{array}$ \\
\hline
\end{tabular}

Allocation concealment (selection bias) Unclear risk $\quad$ Not described. 


\begin{tabular}{|c|c|c|}
\hline $\begin{array}{l}\text { Blinding of participants and personnel } \\
\text { (performance bias) } \\
\text { All outcomes }\end{array}$ & High risk & $\begin{array}{l}\text { "The trial was single-blinded in that patients were aware". Page } \\
284\end{array}$ \\
\hline $\begin{array}{l}\text { Blinding of outcome assessment (detection } \\
\text { bias) } \\
\text { All outcomes }\end{array}$ & Low risk & $\begin{array}{l}\text { "Physicians who assessed the outcome were unaware of the treatment } \\
\text { type that the patient had received". Page } 284\end{array}$ \\
\hline $\begin{array}{l}\text { Incomplete outcome data (attrition bias) } \\
\text { All outcomes }\end{array}$ & Low risk & All randomised patients were included in the study analysis. \\
\hline Selective reporting (reporting bias) & High risk & Progression at 2 years was not reported. \\
\hline Other bias & Unclear risk & It's unclear if this study was sponsored. \\
\hline \multicolumn{3}{|l|}{ European Study Group 1998} \\
\hline \multicolumn{3}{|l|}{ Methods } \\
\hline Participants & \multicolumn{2}{|c|}{$\begin{array}{l}\text { Age: } 18-55 \text { years; clinical definite SPMS; } \geq 2 \text { relapses or } \geq 1.0 \text { EDSS points in the } 2 \\
\text { years before randomisation; EDSS 3.0-6.5; mean disease duration } 13 \text { years }\end{array}$} \\
\hline Interventions & \multicolumn{2}{|c|}{$\begin{array}{l}\text { Subcutaneous injection every other day of IFN-1b } 250 \text { ug ( } 8.0 \text { million international } \\
\text { units [MIU]), for } 36 \text { months (n. } 360 \text { ) } \\
\text { Placebo (unspecified) for } 36 \text { months (n. 358). }\end{array}$} \\
\hline Outcomes & \multicolumn{2}{|c|}{ Relapses at 36 months. Progression at 36 months } \\
\hline Notes & \multicolumn{2}{|c|}{ Funding: Schering AG, Berlin } \\
\hline
\end{tabular}

\section{Risk of bias}

\begin{tabular}{|c|c|c|}
\hline Bias & Authors' judgement & Support for judgement \\
\hline $\begin{array}{l}\text { Random sequence generation (selection } \\
\text { bias) }\end{array}$ & Low risk & $\begin{array}{l}\text { "Central randomisation schedule assigned placebo or IFN } 3-1 b \text { to } \\
\text { blocks of six patients in a } 1 / 1 \text { ratio". Page } 1492\end{array}$ \\
\hline Allocation concealment (selection bias) & Low risk & $\begin{array}{l}\text { "Access to the code was strictly limited according to study protocol". } \\
\text { Page } 1492\end{array}$ \\
\hline $\begin{array}{l}\text { Blinding of participants and personnel } \\
\text { (performance bias) } \\
\text { All outcomes }\end{array}$ & Unclear risk & $\begin{array}{l}\text { "Separate treating and examining physicians were employed... } \\
\text { IFN } \beta-16 \text { was indistinguishable from placebo". Page } 1492\end{array}$ \\
\hline $\begin{array}{l}\text { Blinding of outcome assessment (detection } \\
\text { bias) } \\
\text { All outcomes }\end{array}$ & Unclear risk & $\begin{array}{l}\text { "Evaluating physicians received no potentially unmasking informa- } \\
\text { tion from the treating physicians, and were allowed to speak to pa- } \\
\text { tients only as necessary to carry out neurological tests". Page } 1492\end{array}$ \\
\hline
\end{tabular}


It is unclear if the 3 years evaluation was double blind or open for the early study termination

\begin{tabular}{l|l|l}
$\begin{array}{l}\text { Incomplete outcome data (attrition bias) } \\
\text { All outcomes }\end{array}$ & High risk & $\begin{array}{l}90(25 \%) \text { of } 360 \text { patients in the treatment group and } 97 \text { (27\%) } \\
\text { of } 358 \text { controls had not completed the scheduled 3 years' follow- } \\
\text { up because the study had ended prematurely for benefit }\end{array}$ \\
\hline $\begin{array}{l}\text { Selective reporting (reporting bias) } \\
\text { Other bias }\end{array}$ & Low risk & The published reports included all expected efficacy outcomes \\
\hline
\end{tabular}

\section{EVIDENCE 2007}

\begin{tabular}{ll}
\hline Methods & RCT \\
\hline Participants & $\begin{array}{l}\text { Age: } 18-55 \text { years; clinical or laboratory-supported definite RRMS; EDSS 0-5.5; median } \\
\text { disease duration } 4 \text { years; } \geq 2 \text { relapses in the } 2 \text { years before randomisation }\end{array}$ \\
\hline Interventions & IFNß-1a (Rebif) $44 \mu \mathrm{g}$ subcutaneous three times a week (n. 339) \\
\hline IFNß-1a (Avonex) $30 \mu \mathrm{g}$ intramuscular once a week (n. 338)
\end{tabular}

\section{Risk of bias}

\begin{tabular}{|c|c|c|}
\hline Bias & Authors' judgement & Support for judgement \\
\hline $\begin{array}{l}\text { Random sequence generation (selection } \\
\text { bias) }\end{array}$ & Low risk & $\begin{array}{l}\text { "Computer-generated scheme with block size of } 6 \text { followed by } \\
\text { block size of } 4 \text { ". Page } 2033\end{array}$ \\
\hline
\end{tabular}

\begin{tabular}{|c|c|c|}
\hline Allocation concealment (selection bias) & Unclear risk & Not described \\
\hline $\begin{array}{l}\text { Blinding of participants and personnel } \\
\text { (performance bias) } \\
\text { All outcomes }\end{array}$ & High risk & $\begin{array}{l}\text { "Patients and a treating physician who was not involved in end } \\
\text { point assessment were aware of treatment assignments". Page } 2033\end{array}$ \\
\hline
\end{tabular}

Blinding of outcome assessment (detection Low risk bias)

All outcomes

"Evaluating physicians who were blinded to the patients' treatment and symptoms performed all clinical exams”. Page 2033

Incomplete outcome data (attrition bias) Low risk All outcomes

Losses to follow-up not included in analysis: IFN- $\beta$ 1a (Avonex) 9.5\%; IFN- $\beta 1$ a (rebif) $12 \%$

Selective reporting (reporting bias)

High risk

Only relapses at 12 months were reported. 
EVIDENCE 2007 (Continued)

Other bias

High risk

Data management and study analysis were done by Serono. Sustained disability progression confirmed at 3 months' follow-up

Fazekas 1997

Methods

Participants

Age: 15-64 years; clinical definite RRMS; EDSS, range 1.0-6.0; disease duration, range: $5.7-8.6$ years; $\geq 2$ relapses in the 2 years before randomisation

Interventions

Immunoglobulins $0.15-0.20 \mathrm{gm} / \mathrm{kg}$ body weight intravenously monthly (n. 75)

Placebo (n. 73).

Outcomes Relapses at 24 months.

Notes $\quad$ Funding: Sero-Merieux (Vienna, Austria)

Risk of bias

Bias

Authors' judgement Support for judgement

Random sequence generation (selection Low risk bias)

"Centralised computer-generated randomisation schedule with stratification by centre, age, sex, and deterioration rate." Page 590

Allocation concealment (selection bias) Low risk "Randomly and centrally allocated". Page 590

Blinding of participants and personnel High risk (performance bias)

All outcomes

"Infusions of intravenous immunoglobulinsand placebo were identical in appearance and were stored in plastic bags for concealment during administration". Page 590

The treating physician was aware of treatment.

Blinding of outcome assessment (detection Low risk bias)

"The assessing physician was unaware of treatment assignment". Page 590

All outcomes

\begin{tabular}{l|l|l}
\hline $\begin{array}{l}\text { Incomplete outcome data (attrition bias) } \\
\text { All outcomes }\end{array}$ & High risk & $\begin{array}{l}64(85 \%) \text { patients in the intravenous immunoglobulins group } \\
\text { and } 56(75 \%) \text { in the placebo group completed the trial }\end{array}$ \\
\hline Selective reporting (reporting bias) & Low risk & The published reports included all expected efficacy outcomes \\
\hline Other bias & Unclear risk & $\begin{array}{l}\text { Definition of sustained disability progression was not clearly } \\
\text { reported }\end{array}$ \\
\hline
\end{tabular}


Fazekas 2008

\begin{tabular}{ll}
\hline Methods & RCT \\
\hline Participants & $\begin{array}{l}\text { Age: } 15-64 \text { years; clinical definite RRMS; mean EDSS 2.0; disease duration } 1.3-1.6 \\
\text { years; } \geq 2 \text { relapses in the } 2 \text { years before randomisation }\end{array}$ \\
\hline Interventions & $\begin{array}{l}\text { Immunoglobulins } 0.2 \mathrm{gm} / \mathrm{kg} \text { body weight intravenously monthly (n. 45) } \\
\text { Immunoglobulins } 0.4 \mathrm{gm} / \mathrm{kg} \text { body weight intravenously monthly (n. 42) } \\
\text { Placebo (n. } 41) .\end{array}$ \\
\hline Outcomes & Relapses at 12 months. \\
\hline Notes & Funding: Bayer HealthCare AG. \\
\hline
\end{tabular}

Risk of bias

\begin{tabular}{|c|c|c|}
\hline Bias & Authors' judgement & Support for judgement \\
\hline $\begin{array}{l}\text { Random sequence generation (selection } \\
\text { bias) }\end{array}$ & Low risk & $\begin{array}{l}\text { "The random code number was computer generated by the Statistics } \\
\text { and Data System Department of Bayer." Page } 266\end{array}$ \\
\hline Allocation concealment (selection bias) & Low risk & $\begin{array}{l}\text { "Randomisation performed by an unblinded pharmacist who as- } \\
\text { signed code numbers from sealed envelopes in a sequential manner". } \\
\text { Page } 266\end{array}$ \\
\hline $\begin{array}{l}\text { Blinding of participants and personnel } \\
\text { (performance bias) } \\
\text { All outcomes }\end{array}$ & Unclear risk & Not clearly reported. \\
\hline $\begin{array}{l}\text { Blinding of outcome assessment (detection } \\
\text { bias) } \\
\text { All outcomes }\end{array}$ & Unclear risk & $\begin{array}{l}\text { Endpoints "assessed by an evaluating physician who was otherwise } \\
\text { not involved in patient care" }\end{array}$ \\
\hline $\begin{array}{l}\text { Incomplete outcome data (attrition bias) } \\
\text { All outcomes }\end{array}$ & Unclear risk & $\begin{array}{l}\text { Dropouts: intravenous immunoglobulins } 0.2 \mathrm{~g}: 7 / 45(15 \%) \text {; } \\
\text { intravenous immunoglobulins } 0.4 \mathrm{~g} \text { : } 4 / 42 \text { ( } 9 \%) \text {; placebo } 4 / 41 \\
(10 \%)\end{array}$ \\
\hline Selective reporting (reporting bias) & High risk & Only relapses at 12 months were reported. \\
\hline Other bias & High risk & Bayer HealthCare AG supported the study. \\
\hline
\end{tabular}

Ghezzi 1989

\begin{tabular}{ll}
\hline Methods & RCT \\
\hline Participants & $\begin{array}{l}\text { Age not reported; definite RRMS or SPMS; disease duration 5-15 years; EDSS 2.5-6.5; } \\
\leq 1 \text { relapses in the } 2 \text { years before randomisation }\end{array}$
\end{tabular}




\section{Ghezzi 1989 (Continued)}

\begin{tabular}{|c|c|c|}
\hline Interventions & \multicolumn{2}{|c|}{$\begin{array}{l}\text { Azathioprine } 2.5 \text { mg/Kg/body weight oral daily (n. 93) } \\
\text { Placebo (n. 92) }\end{array}$} \\
\hline Outcomes & \multicolumn{2}{|c|}{ Relapses 24 months. Progression at 24 months } \\
\hline Notes & \multicolumn{2}{|l|}{ Funding: Not reported } \\
\hline \multicolumn{3}{|l|}{ Risk of bias } \\
\hline Bias & Authors' judgement & Support for judgement \\
\hline $\begin{array}{l}\text { Random sequence generation (selection } \\
\text { bias) }\end{array}$ & Unclear risk & Not described. \\
\hline Allocation concealment (selection bias) & Unclear risk & Not described. \\
\hline $\begin{array}{l}\text { Blinding of participants and personnel } \\
\text { (performance bias) } \\
\text { All outcomes }\end{array}$ & High risk & No blinding. \\
\hline $\begin{array}{l}\text { Blinding of outcome assessment (detection } \\
\text { bias) } \\
\text { All outcomes }\end{array}$ & Low risk & Examining neurologist blinded to treatment arm. \\
\hline $\begin{array}{l}\text { Incomplete outcome data (attrition bias) } \\
\text { All outcomes }\end{array}$ & High risk & $\begin{array}{l}\text { Losses to follow-up not included in the study analysis: treatment } \\
26 \% \text {; placebo } 28 \%\end{array}$ \\
\hline Selective reporting (reporting bias) & Low risk & $\begin{array}{l}\text { The published reports included all expected efficacy outcomes } \\
\text { and those outcomes that were pre-specifi ed in the methods sec- } \\
\text { tion }\end{array}$ \\
\hline Other bias & Unclear risk & $\begin{array}{l}\text { Definition of sustained disability progression not clearly re- } \\
\text { ported. It is unclear if the study was sponsored }\end{array}$ \\
\hline
\end{tabular}

\section{Goodkin 1991}

\begin{tabular}{|c|c|}
\hline Methods & RCT \\
\hline Participants & $\begin{array}{l}\text { Mean age: } 30 \text { years; definite RRMS; disease duration } 5-15 \text { years; EDSS 2.5-6.5; } \leq 1 \\
\text { relapses in the } 2 \text { years before randomisation }\end{array}$ \\
\hline Interventions & $\begin{array}{l}\text { Azathioprine } 3.0 \mathrm{mg} / \mathrm{Kg} / \text { body weight oral daily for } 24 \text { moths (n. 30) } \\
\text { Placebo for } 24 \text { months (n. 29) }\end{array}$ \\
\hline Outcomes & Relapses 12 and 24 months. Progression at 24 months \\
\hline Notes & Funding: Wellcome Company \\
\hline
\end{tabular}




\section{Goodkin 1991 (Continued)}

\section{Risk of bias}

\begin{tabular}{|c|c|c|}
\hline Bias & Authors' judgement & Support for judgement \\
\hline $\begin{array}{l}\text { Random sequence generation (selection } \\
\text { bias) }\end{array}$ & Low risk & $\begin{array}{l}\text { "Randomised by the statistician using random number tables". } \\
\text { Page } 21\end{array}$ \\
\hline Allocation concealment (selection bias) & Unclear risk & Not described \\
\hline $\begin{array}{l}\text { Blinding of participants and personnel } \\
\text { (performance bias) } \\
\text { All outcomes }\end{array}$ & Low risk & Patients and personnel were blinded. \\
\hline $\begin{array}{l}\text { Blinding of outcome assessment (detection } \\
\text { bias) } \\
\text { All outcomes }\end{array}$ & Low risk & The examining neurologist was blinded. \\
\hline $\begin{array}{l}\text { Incomplete outcome data (attrition bias) } \\
\text { All outcomes }\end{array}$ & Low risk & $\begin{array}{l}7 \text { (12\%) people were lost to } 2 \text { years follow-up ( } 3 \text { azathioprine, } \\
4 \text { placebo) }\end{array}$ \\
\hline Selective reporting (reporting bias) & Low risk & The published reports included all expected efficacy outcomes \\
\hline Other bias & Unclear risk & Definition of sustained disbility progression not clearly reported \\
\hline
\end{tabular}

Goodkin 1995

\begin{tabular}{|c|c|c|}
\hline Methods & \multicolumn{2}{|l|}{ RCT } \\
\hline Participants & \multicolumn{2}{|c|}{$\begin{array}{l}\text { Age: } 21-60 \text { years; definite PPMS or SPMS ; disease duration }>1 \text { years; EDSS } 3.0-6.5 \text {; } \leq \\
1 \text { relapses in the } 2 \text { years before randomisation }\end{array}$} \\
\hline Interventions & \multicolumn{2}{|c|}{$\begin{array}{l}\text { Methotrexate } 7.5 \text { mg oral weekly for } 24 \text { months (n. 31) } \\
\text { Placebo for } 24 \text { months (n. 29) }\end{array}$} \\
\hline Outcomes & \multicolumn{2}{|c|}{ Relapses at 12 and 24 months. Progression at 24 months } \\
\hline Notes & \multicolumn{2}{|l|}{ Funding: none } \\
\hline \multicolumn{3}{|l|}{ Risk of bias } \\
\hline Bias & Authors' judgement & Support for judgement \\
\hline $\begin{array}{l}\text { Random sequence generation (selection } \\
\text { bias) }\end{array}$ & Unclear risk & $\begin{array}{l}\text { "The randomisation scheme was developed prior to the initiation of } \\
\text { the study and was blocked in groups of } 10 \text { ". Page } 32\end{array}$ \\
\hline
\end{tabular}




\section{Goodkin 1995 (Continued)}

\begin{tabular}{|c|c|c|}
\hline Allocation concealment (selection bias) & High risk & $\begin{array}{l}\text { "Treatment assignments were made by the unblinded study coordi- } \\
\text { nator who appeared to be not responsible for patients" recruitment". } \\
\text { Page } 32\end{array}$ \\
\hline $\begin{array}{l}\text { Blinding of participants and personnel } \\
\text { (performance bias) } \\
\text { All outcomes }\end{array}$ & Unclear risk & It was not clearly reported \\
\hline $\begin{array}{l}\text { Blinding of outcome assessment (detection } \\
\text { bias) } \\
\text { All outcomes }\end{array}$ & Low risk & $\begin{array}{l}\text { "The examining neurologist performed all neurological examina- } \\
\text { tions without reference to earlier examinations and was not per- } \\
\text { mitted to talk to the patient or treating physician about the general } \\
\text { progress of the study, clinical events, or therapy provided to any study } \\
\text { participants." Page } 32\end{array}$ \\
\hline $\begin{array}{l}\text { Incomplete outcome data (attrition bias) } \\
\text { All outcomes }\end{array}$ & Low risk & $\begin{array}{l}\text { Losses to follow-up not included in the study analysis: treatment } \\
2 / 31 \text {; placebo } 0 / 29\end{array}$ \\
\hline Selective reporting (reporting bias) & Low risk & $\begin{array}{l}\text { The published reports included all expected efficacy outcomes } \\
\text { and those outcomes that were pre-specifi ed in the methods sec- } \\
\text { tion }\end{array}$ \\
\hline Other bias & High risk & $\begin{array}{l}\text { "Sustained" disability progression was confirmed at } \geq 2 \text { months } \\
\text { of follow-up }\end{array}$ \\
\hline
\end{tabular}

\section{Hartung 2002}

\begin{tabular}{|c|c|c|}
\hline Methods & \multicolumn{2}{|l|}{ RCT } \\
\hline Participants & \multicolumn{2}{|c|}{$\begin{array}{l}\text { Age: } 18-65 \text { years; definite SPMS or PRMS; mean disease duration } 10 \text { years; } \geq 1.0 \text { EDSS } \\
\mathrm{n} \text { the } 18 \text { months before randomisation; no clinical relapses or treatment with steroids } \\
\text { for at least } 8 \text { weeks before enrolment; EDSS } 3.0-6.0\end{array}$} \\
\hline Interventions & \multicolumn{2}{|c|}{$\begin{array}{l}\text { Mitoxantrone } 5 \mathrm{mg} / \mathrm{m}^{2} \text { body surface area intravenously every } 3 \text { months (n. 66) } \\
\text { Mitoxantrone } 12 \mathrm{mg} / \mathrm{m}^{2} \text { body surface area intravenously every } 3 \text { months (n. 63) } \\
\text { Placebo (n. 65). }\end{array}$} \\
\hline Outcomes & \multicolumn{2}{|c|}{ Relapses at 24 months. Progression at 24 months. } \\
\hline Notes & \multicolumn{2}{|c|}{ Funding: Wyeth-Lederle Benelux and Germany } \\
\hline \multicolumn{3}{|l|}{ Risk of bias } \\
\hline Bias & Authors' judgement & Support for judgement \\
\hline $\begin{array}{l}\text { Random sequence generation (selection } \\
\text { bias) }\end{array}$ & Low risk & $\begin{array}{l}\text { "Randomisation by a computer-generated schedule, block size of } \\
\text { three". Page } 2019\end{array}$ \\
\hline
\end{tabular}




\section{Hartung 2002 (Continued)}

\begin{tabular}{l|l|l}
\hline Allocation concealment (selection bias) & Unclear risk & Not described \\
\hline $\begin{array}{l}\text { Blinding of participants and personnel } \\
\text { (performance bias) } \\
\text { All outcomes }\end{array}$ & High risk & $\begin{array}{l}\text { "A separate treating physician was aware of treatment assignment. } \\
\text { " Page } 2019\end{array}$ \\
\hline $\begin{array}{l}\text { Blinding of outcome assessment (detection } \\
\text { bias) } \\
\text { All outcomes }\end{array}$ & Low risk & $\begin{array}{l}\text { "Neurologist who assessed outcome measures was unaware of treat- } \\
\text { ment assignment (assessing physician). Page 2019 }\end{array}$ \\
\hline $\begin{array}{l}\text { Incomplete outcome data (attrition bias) } \\
\text { All outcomes }\end{array}$ & Low risk & $\begin{array}{l}\text { Losses to follow-up not included in the study analysis: treatment } \\
\text { arms 3/63 (5\%) and 2/66 (3\%); placebo 1/65 (1.5\%) }\end{array}$ \\
\hline $\begin{array}{l}\text { Selective reporting (reporting bias) } \\
\text { Other bias }\end{array}$ & Low risk & The published reports included all expected efficacy outcomes \\
\hline
\end{tabular}

Hommes 2004

\begin{tabular}{ll}
\hline Methods & RCT \\
\hline Participants & $\begin{array}{l}\text { Age: } 18-55 \text { years; clinical definite SPMS; progression } \geq 1.0 \text { EDSS points in the } 2 \text { years } \\
\text { before randomisation; EDSS 3.0-6.5; disease duration } \geq 3 \text { years }\end{array}$ \\
\hline Interventions & $\begin{array}{l}\text { Immunoglobulins } 1 \text { gm/kg body weight intravenously monthly (n. 159) } \\
\text { Placebo (n. 159). }\end{array}$ \\
\hline Outcomes & Relapses at 12 and 24 months. Progression at 24 months. \\
\hline Notes & Funding: Bayer Corporation.
\end{tabular}

\section{Risk of bias}

Bias

Random sequence generation (selection Unclear risk bias)

\section{Authors' judgement Support for judgement}

"The randomisation was done centrally as block randomisation with stratification by centre." Page 1150

"Concealment of treatment was guaranteed by use of an albumin solution identical in appearance to the study medication, with identical labelling and opaque plastic wrapping." Page 1150

Blinding of participants and personnel Low risk (performance bias)

All outcomes
"Concealment of treatment was guaranteed by use of an albumin solution

identical in appearance to the study medication, with identical labelling and opaque plastic wrapping... a treating neurologist or 
a study nurse administered the study drug.. Physicians and study nurses were unaware of treatment allocation. " Page 1150

Blinding of outcome assessment (detection Low risk bias)

All outcomes

Incomplete outcome data (attrition bias) Low risk All outcomes

"The clinical assessment of the patients was made by an evaluating neurologist, who was not allowed to discuss therapy or adverse effects with the patients." Page 1150

"32 patients (10\%) withdrew from the study.Thus, complete data for 27 months were available for 280 (90\%) patients.” Page 1152

\begin{tabular}{|c|c|c|}
\hline Selective reporting (reporting bias) & Low risk & The published reports included all expected efficacy outcomes \\
\hline Other bias & High risk & $\begin{array}{l}\text { Bayer Corporation was involved in every phase of the trial. Sus- } \\
\text { tained disability progression confirmed at } 3 \text { months' follow-up }\end{array}$ \\
\hline
\end{tabular}

IFNB MS Group 1993

\begin{tabular}{ll}
\hline Methods & RCT \\
\hline Participants & $\begin{array}{l}\text { Age: } 18-50 \text { years; clinical or laboratory-supported definite RRMS; EDSS } \leq 5.5 \text {; disease } \\
\text { duration }>1 \text { year; } \geq 2 \text { relapses in the } 2 \text { years before randomisation; no relapses for at } \\
\text { least } 1 \text { month before randomisation }\end{array}$ \\
\hline Interventions & $\begin{array}{l}\text { IFNß }-1 \mathrm{~b} \text { (Betaseron) } 50 \mu \mathrm{g} \text { subcutaneously every other day (n. 125) } \\
\text { IFNß }-1 \mathrm{~b} \text { (Betaseron) } 250 \mu \mathrm{g} \text { subcutaneously every other day (n) 124) } \\
\text { Placebo (n. 123). }\end{array}$ \\
\hline Outcomes & Relapses at 24 months. Progression at 24 months. \\
\hline Notes & Funding: Triton Biosciences, Inc., Alameda, CA and Berlex Laboratories Inc \\
\hline
\end{tabular}

\section{Risk of bias}

\section{Bias}

Random sequence generation (selection Unclear risk bias)

\section{Authors' judgement Support for judgement}

Not described

Not described

"One treating neurologist who knew about side effects, reviewed laboratory findings for toxicity, and was responsible for overall care". Page S4

Endpoints were measured by "One examining neurologist who was not aware of drug side effects". Page S4 bias)

All outcomes 
IFNB MS Group 1993 (Continued)

\begin{tabular}{|c|c|c|}
\hline $\begin{array}{l}\text { Incomplete outcome data (attrition bias) } \\
\text { All outcomes }\end{array}$ & Unclear risk & $\begin{array}{l}\text { Withdrawals and losses to follow-up were difficult to find, and } \\
\text { different data were given in different articles about the same } \\
\text { trial. Specifically, } 2 \text { years after randomisation, withdrawals plus } \\
\text { losses to follow-up in the treated group were described as either } \\
18 \text { or } 20 \text { in the } 1.6 \text { million IU interferon group and as } 24 \text { or } \\
25 \text { in the } 8 \text { million IU group. Patients included into analysis in } \\
\text { the treated group were described as either } 184 \text { or } 205 \text { in the } 1.6 \\
\text { million IU interferon group and as } 244 \text { or } 255 \text { in the } 8 \text { million } \\
\text { IU group }\end{array}$ \\
\hline
\end{tabular}

Selective reporting (reporting bias) Low risk

The published reports included all expected efficacy outcomes and those outcomes that were pre-specifi ed in the methods section

Other bias

High risk

"Sustained" disability progression was confirmed at 3 months' follow-up. The role of the study sponsor was unclear

\section{IMPACT 2002}

\begin{tabular}{|c|c|c|}
\hline Methods & \multicolumn{2}{|l|}{ RCT } \\
\hline Participants & \multicolumn{2}{|c|}{$\begin{array}{l}\text { Age: } 18-55 \text { years; clinical definite SPMS; progression not reported; EDSS 3.5-6.5; mean } \\
\text { disease duration } 16 \text { years }\end{array}$} \\
\hline Interventions & \multicolumn{2}{|c|}{$\begin{array}{l}\text { IFNß -1a (Avonex) } 60 \mu \mathrm{g} \text { intramuscular injections weekly (n. 217) } \\
\text { Placebo (n. 219) }\end{array}$} \\
\hline Outcomes & \multicolumn{2}{|c|}{ Relapses at 24 months. Progression at 24 months. } \\
\hline Notes & \multicolumn{2}{|c|}{ Funding: BIOGEN INC. } \\
\hline \multicolumn{3}{|l|}{ Risk of bias } \\
\hline Bias & Authors' judgement & Support for judgement \\
\hline $\begin{array}{l}\text { Random sequence generation (selection } \\
\text { bias) }\end{array}$ & Unclear risk & $\begin{array}{l}\text { "The contract research organization computer generated two mini- } \\
\text { mization schemes, one for North America and one for Europe and } \\
\text { Israel'. Page } 680\end{array}$ \\
\hline Allocation concealment (selection bias) & Unclear risk & Not described \\
\hline $\begin{array}{l}\text { Blinding of participants and personnel } \\
\text { (performance bias) } \\
\text { All outcomes }\end{array}$ & Unclear risk & $\begin{array}{l}\text { "A treating nurse and neurologist were responsible for clinical man- } \\
\text { agement of the subjects". Page } 680\end{array}$ \\
\hline $\begin{array}{l}\text { Blinding of outcome assessment (detection } \\
\text { bias) } \\
\text { All outcomes }\end{array}$ & Unclear risk & $\begin{array}{l}\text { "The examining neurologist was not involved with any other aspect } \\
\text { of subject care, and neither had access to the results of prior examina- } \\
\text { tions or to clinical information that might compromise blinding". }\end{array}$ \\
\hline
\end{tabular}

Immunomodulators and immunosuppressants for multiple sclerosis: a network meta-analysis (Review)

Copyright @ 2013 The Cochrane Collaboration. Published by John Wiley \& Sons, Ltd. 
IMPACT 2002 (Continued)

Page 680

\begin{tabular}{|c|c|c|}
\hline $\begin{array}{l}\text { Incomplete outcome data (attrition bias) } \\
\text { All outcomes }\end{array}$ & High risk & $\begin{array}{l}\text { "Twenty-three (11\%) subjects in the placebo group and } 29 \text { (13\%) } \\
\text { subjects in the IFN-1 a group failed to complete } 24 \text { months offollow- } \\
\text { up. The between-group difference in reason for study discontinuation } \\
\text { was subject request (six placebo subjects vs } 16 \text { IFN-1 a subjects, } p< \\
0.05 \text { )" Page } 682\end{array}$ \\
\hline Selective reporting (reporting bias) & Low risk & The published reports included all expected efficacy outcomes \\
\hline Other bias & High risk & $\begin{array}{l}\text { Sustained disability progression confirmed at } 3 \text { months' follow- } \\
\text { up. Unclear the role of Biogen Inc. The FDA letters of July 23, } \\
1998 \text {, December 6, 1999, and March 8, } 2000 \text { informed Biogen } \\
\text { that the primary study endpoint, the Multiple Sclerosis Func- } \\
\text { tional Composite (MSFC), is not a validated efficacy outcome } \\
\text { measure and therefore is not appropriate as a primary efficacy } \\
\text { endpoint in this Phase } 3 \text { study (FDA 2001) }\end{array}$ \\
\hline
\end{tabular}

INCOMIN 2002

\begin{tabular}{ll}
\hline Methods & RCT \\
\hline Participants & $\begin{array}{l}\text { Age: } 18-50 \text { years; clinical definite RRMS; mean disease duration } 6 \text { years; EDSS 1.0-3. } \\
5 ; \geq 2 \text { relapses in the } 2 \text { years before randomisation; in remission at randomisation }\end{array}$ \\
\hline Interventions & IFNß $-1 \mathrm{~b} 250 \mu \mathrm{g}$ subcutaneously every other day for 24 months (n. 96) \\
\hline IFNß $-1 \mathrm{a}($ Avonex) $30 \mu \mathrm{g}$ by weekly intramuscular injections for 24 months (n. 92)
\end{tabular}

\section{Risk of bias}

\begin{tabular}{|c|c|c|}
\hline Bias & Authors' judgement & Support for judgement \\
\hline $\begin{array}{l}\text { Random sequence generation (selection } \\
\text { bias) }\end{array}$ & Low risk & $\begin{array}{l}\text { "Randomisation followed computer-generated random sequences of } \\
\text { digits that were different for each centre and for each sex, to achieve } \\
\text { centre and sex stratification". Page } 1454\end{array}$ \\
\hline Allocation concealment (selection bias) & Low risk & $\begin{array}{l}\text { "The codes were randomly assigned to treatments by an independent } \\
\text { team of statisticians unaware of the patient's clinical characteristics". } \\
\text { Page } 1454\end{array}$ \\
\hline $\begin{array}{l}\text { Blinding of participants and personnel } \\
\text { (performance bias) } \\
\text { All outcomes }\end{array}$ & High risk & $\begin{array}{l}\text { "All clinical outcomes were assessed in an open-label manner". Page } \\
1454\end{array}$ \\
\hline
\end{tabular}

Immunomodulators and immunosuppressants for multiple sclerosis: a network meta-analysis (Review) 
INCOMIN 2002 (Continued)

\begin{tabular}{|c|c|c|}
\hline $\begin{array}{l}\text { Blinding of outcome assessment (detection } \\
\text { bias) } \\
\text { All outcomes }\end{array}$ & High risk & $\begin{array}{l}\text { "All clinical outcomes were assessed in an open-label manner". Page } \\
1454\end{array}$ \\
\hline $\begin{array}{l}\text { Incomplete outcome data (attrition bias) } \\
\text { All outcomes }\end{array}$ & Low risk & $\begin{array}{l}\text { Losses to follow-up not included in analysis: IFNß -1a } 4 / 92 \\
(4 \%) \text {; IFNß - 1b 2/96 (2\%) }\end{array}$ \\
\hline Selective reporting (reporting bias) & Low risk & The published reports included all expected efficacy outcomes \\
\hline Other bias & Low risk & The study appears to be free of other sources of bias. \\
\hline
\end{tabular}

\section{Johnson 1995}

\begin{tabular}{l|l}
\hline Methods & RCT \\
\hline Participants & $\begin{array}{l}\text { Age: } 18-45 \text { years; clinical or laboratory-supported definite RRMS; EDSS 0-5.0; } \geq 2 \\
\text { relapses in the } 2 \text { years before randomisation }\end{array}$ \\
\hline Interventions & $\begin{array}{l}\text { Glatiramer acetate } 20 \text { mg subcutaneously every day (n. 125). } \\
\text { Placebo (n. 126) }\end{array}$ \\
\hline Outcomes & Relapses at 24 months. Progression at 24 months. \\
\hline Notes & Funding: Teva Pharmaceutical. \\
\hline
\end{tabular}

\section{Risk of bias}

\begin{tabular}{|c|c|c|}
\hline Bias & Authors' judgement & Support for judgement \\
\hline $\begin{array}{l}\text { Random sequence generation (selection } \\
\text { bias) }\end{array}$ & Unclear risk & Not described \\
\hline Allocation concealment (selection bias) & Unclear risk & “A centralized randomization scheme was used". Page 1270 \\
\hline $\begin{array}{l}\text { Blinding of participants and personnel } \\
\text { (performance bias) } \\
\text { All outcomes }\end{array}$ & Unclear risk & “Treating neurologists were blinded”. Page 1270 \\
\hline $\begin{array}{l}\text { Blinding of outcome assessment (detection } \\
\text { bias) } \\
\text { All outcomes }\end{array}$ & Unclear risk & “Examining neurologists were blinded". Page 1270 \\
\hline $\begin{array}{l}\text { Incomplete outcome data (attrition bias) } \\
\text { All outcomes }\end{array}$ & Low risk & $\begin{array}{l}\text { Withdrawals: glatiramer acetate }=19(15 \%) ; \text { placebo }=17(13 \%) \\
\text {.They were included in the analyses }\end{array}$ \\
\hline Selective reporting (reporting bias) & Low risk & The published reports included all expected efficacy outcomes \\
\hline
\end{tabular}


Johnson 1995 (Continued)

$\begin{array}{ll}\text { Other bias } \quad \text { High risk } & \begin{array}{l}\text { “Sustained” disability progression confirmed at } 3 \text { months' fol- } \\ \text { low-up }\end{array}\end{array}$

Knobler 1993

\begin{tabular}{|c|c|c|}
\hline Methods & \multicolumn{2}{|l|}{ RCT } \\
\hline Participants & \multicolumn{2}{|c|}{$\begin{array}{l}\text { Age: } 18-50 \text { years; clinical definite RRMS; EDSS } \leq 5.5 \text {; disease duration } \geq 1 \text { and } \leq 15 \\
\text { years; } \geq 2 \text { relapses in the } 2 \text { years before randomisation; in remission at randomisation }\end{array}$} \\
\hline Interventions & \multicolumn{2}{|c|}{$\begin{array}{l}\text { IFNß -1b } 25 \mu \mathrm{g} \text { subcutaneous three times weekly for three years (n. 6) } \\
\text { IFNß -1b } 125 \mu \mathrm{g} \text { subcutaneous three times weekly for three years (n. 6) } \\
\text { IFNß -1b } 250 \mu \mathrm{g} \text { subcutaneous three times weekly for three years (n. 6) } \\
\text { IFNß -1b } 500 \mu \mathrm{g} \text { subcutaneous three times weekly for three years (n. 6) } \\
\text { Placebo for three years (n. 7) }\end{array}$} \\
\hline Outcomes & \multicolumn{2}{|l|}{ Relapses at 12 months } \\
\hline Notes & \multicolumn{2}{|c|}{ Funding: Triton Biosciences, Inc., Alameda, CA and Berlex Laboratories Inc } \\
\hline \multicolumn{3}{|l|}{ Risk of bias } \\
\hline Bias & Authors' judgement & Support for judgement \\
\hline $\begin{array}{l}\text { Random sequence generation (selection } \\
\text { bias) }\end{array}$ & Unclear risk & Not described \\
\hline Allocation concealment (selection bias) & Unclear risk & Not described \\
\hline $\begin{array}{l}\text { Blinding of participants and personnel } \\
\text { (performance bias) } \\
\text { All outcomes }\end{array}$ & High risk & “One treating neurologist not blinded". Page 335 \\
\hline $\begin{array}{l}\text { Blinding of outcome assessment (detection } \\
\text { bias) } \\
\text { All outcomes }\end{array}$ & Low risk & $\begin{array}{l}\text { "An examining neurologist blinded to treatment arms". Page } \\
335\end{array}$ \\
\hline $\begin{array}{l}\text { Incomplete outcome data (attrition bias) } \\
\text { All outcomes }\end{array}$ & Unclear risk & Withdrawals and losses to follow-up not described \\
\hline Selective reporting (reporting bias) & High risk & Progression was not reported. \\
\hline Other bias & Unclear risk & The role of the study sponsor was unclear. \\
\hline
\end{tabular}


Koch-Henriksen 2006

\begin{tabular}{|c|c|c|}
\hline Methods & \multicolumn{2}{|l|}{ RCT } \\
\hline Participants & \multicolumn{2}{|c|}{$\begin{array}{l}\text { Age: } 18-55 \text { years; clinical definite RRMS; disease duration } 0-35 ; \geq 2 \text { relapses within } 2 \\
\text { years before randomisation; EDSS } \leq 5.5\end{array}$} \\
\hline Interventions & \multicolumn{2}{|c|}{$\begin{array}{l}\text { IFNß -1b } 250 \mu \text { g subcutaneous every other day for } 24 \text { months. (n. 158) } \\
\text { IFNß -1a (Rebif) } 22 \mu \mathrm{g} \text { subcutaneous weekly for } 24 \text { months (n. 143) }\end{array}$} \\
\hline Outcomes & \multicolumn{2}{|c|}{ Progression at 24 months } \\
\hline Notes & \multicolumn{2}{|l|}{ Funding: not reported } \\
\hline \multicolumn{3}{|l|}{ Risk of bias } \\
\hline Bias & Authors' judgement & Support for judgement \\
\hline $\begin{array}{l}\text { Random sequence generation (selection } \\
\text { bias) }\end{array}$ & Unclear risk & Not described \\
\hline Allocation concealment (selection bias) & Low risk & $\begin{array}{l}\text { "A central computerized randomization schedule assigned patients } \\
\text { to treatment". Page } 1057\end{array}$ \\
\hline $\begin{array}{l}\text { Blinding of participants and personnel } \\
\text { (performance bias) } \\
\text { All outcomes }\end{array}$ & High risk & $\begin{array}{l}\text { Open label trial. "Blinding was abandoned because it could not } \\
\text { be maintained owing to the different administration schemes of the } \\
\text { two study drugs". Page } 1057\end{array}$ \\
\hline $\begin{array}{l}\text { Blinding of outcome assessment (detection } \\
\text { bias) } \\
\text { All outcomes }\end{array}$ & High risk & Open label trial. Page 1057 \\
\hline $\begin{array}{l}\text { Incomplete outcome data (attrition bias) } \\
\text { All outcomes }\end{array}$ & High risk & $\begin{array}{l}\text { Losses to follow-up not included in analysis: IFNß }-1 \mathrm{~b} 28 \% \text {; } \\
\text { IFNß -1a } 23 \%\end{array}$ \\
\hline Selective reporting (reporting bias) & High risk & Relapses were not reported. \\
\hline Other bias & High risk & $\begin{array}{l}\text { Sustained disability progression confirmed at } 3 \text { months' follow- } \\
\text { up. Is is unclear if the study was sponsored }\end{array}$ \\
\hline
\end{tabular}

Leary 2003

\begin{tabular}{ll}
\hline Methods & RCT \\
\hline Participants & Age: 25-59 years; definite PPMS; disease duration 2-21 years; EDSS 2.0-7.0 \\
\hline Interventions & IFNß-1a (Avonex) $30 \mu \mathrm{g}$ intramuscular weekly for 24 months (n. 15) \\
& $\begin{array}{l}\text { IFNß-1a (Avonex) } 60 \mu \mathrm{g} \text { intramuscular weekly for } 24 \text { months (n. 15) } \\
\text { Placebo for } 24 \text { months (n. 20) }\end{array}$
\end{tabular}


Leary 2003 (Continued)

\begin{tabular}{|c|c|c|}
\hline Outcomes & \multicolumn{2}{|c|}{ Progression at 24 months } \\
\hline Notes & \multicolumn{2}{|l|}{ Funding: BIOGEN } \\
\hline \multicolumn{3}{|l|}{ Risk of bias } \\
\hline Bias & Authors' judgement & Support for judgement \\
\hline $\begin{array}{l}\text { Random sequence generation (selection } \\
\text { bias) }\end{array}$ & Unclear risk & $\begin{array}{l}\text { "The randomization was carried out off-site by Biogen using a ran- } \\
\text { domization block method."Page } 44\end{array}$ \\
\hline Allocation concealment (selection bias) & Low risk & $\begin{array}{l}\text { "The study drug was blinded off-site by Biogen and delivered to the } \\
\text { study centre with the study numbers already allocated. Subjects were } \\
\text { allocated by study number consecutively as they were entered into } \\
\text { the study. A copy of the randomization codes was kept in pharmacy } \\
\text { and by Biogen, but no codes were broken until the study and analysis } \\
\text { was completed". }\end{array}$ \\
\hline $\begin{array}{l}\text { Blinding of participants and personnel } \\
\text { (performance bias) } \\
\text { All outcomes }\end{array}$ & Unclear risk & $\begin{array}{l}\text { "All personnel at the study site (dispensing pharmacists, treating } \\
\text { physicians and EDSS physicians) were blinded to the study drug." } \\
\text { Page } 44\end{array}$ \\
\hline $\begin{array}{l}\text { Blinding of outcome assessment (detection } \\
\text { bias) } \\
\text { All outcomes }\end{array}$ & Low risk & $\begin{array}{l}\text { "EDSS and clinical assessments were performed by an independent } \\
\text { evaluating physician blinded to all clinical information." Page } 44\end{array}$ \\
\hline $\begin{array}{l}\text { Incomplete outcome data (attrition bias) } \\
\text { All outcomes }\end{array}$ & Low risk & 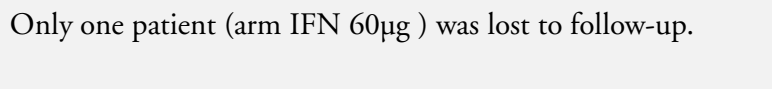 \\
\hline Selective reporting (reporting bias) & High risk & Relapses were not reported. \\
\hline Other bias & High risk & $\begin{array}{l}\text { "Sustained" disability progression was confirmed at } 3 \text { months' } \\
\text { follow-up. Funding: Biogen, Multiple Sclerosis Society of Great } \\
\text { Britain and Northern Ireland }\end{array}$ \\
\hline
\end{tabular}

Lewanska 2002

\begin{tabular}{ll}
\hline Methods & RCT \\
\hline Participants & $\begin{array}{l}\text { Age: } 18-55 \text { years; clinical definite RRMS; EDSS 0-6.5; mean disease duration }>2 \text { years; } \\
\geq 2 \text { relapses in the } 2 \text { years before randomisation }\end{array}$ \\
\hline Interventions & $\begin{array}{l}\text { Intravenous immunoglobulins } 0.2 \mathrm{~g} / \mathrm{kg} / \mathrm{body} \text { weight intravenous monthly for } 12 \\
\text { months.(n. } 17) \\
\text { Intravenous immunoglobulins } 0.4 \mathrm{~g} / \mathrm{kg} / \text { body weight intravenous monthly for } 12 \text { months } \\
\text { (n. } 16) \\
\text { Placebo (saline) for } 12 \text { months (n. 18) }\end{array}$ \\
\hline
\end{tabular}


Lewanska 2002 (Continued)

\begin{tabular}{|c|c|c|}
\hline Outcomes & \multicolumn{2}{|l|}{ Relapses at 12 months } \\
\hline Notes & \multicolumn{2}{|c|}{ Funding: Supported by the KBN (State Research Committee) } \\
\hline \multicolumn{3}{|l|}{ Risk of bias } \\
\hline Bias & Authors' judgement & Support for judgement \\
\hline $\begin{array}{l}\text { Random sequence generation (selection } \\
\text { bias) }\end{array}$ & Low risk & $\begin{array}{l}\text { "The generation of allocation sequence was based on random-num- } \\
\text { ber table." Page } 566\end{array}$ \\
\hline Allocation concealment (selection bias) & Unclear risk & $\begin{array}{l}\text { Infusions of intravenous immunoglobulins and placebo were } \\
\text { stored in identical opaque plastic bags for concealment during } \\
\text { administration. No more information about treatment alloca- } \\
\text { tion }\end{array}$ \\
\hline $\begin{array}{l}\text { Blinding of participants and personnel } \\
\text { (performance bias) } \\
\text { All outcomes }\end{array}$ & Unclear risk & $\begin{array}{l}\text { "Infusions of intravenous immunoglobulinsand placebo were } \\
\text { stored in identical opaque plastic bags for concealment." Page } 566\end{array}$ \\
\hline $\begin{array}{l}\text { Blinding of outcome assessment (detection } \\
\text { bias) } \\
\text { All outcomes }\end{array}$ & Unclear risk & $\begin{array}{l}\text { "Evaluating physician was unaware of the actual treatment alloca- } \\
\text { tion...Monitoring and recording of relapses, con- } \\
\text { comitant treatment, side-eff ects or other medical events were docu- } \\
\text { mented throughout the study." Page } 566\end{array}$ \\
\hline $\begin{array}{l}\text { Incomplete outcome data (attrition bias) } \\
\text { All outcomes }\end{array}$ & Low risk & $\begin{array}{l}49 \text { patients completed the trial: } 15 / 16 \text { in the intravenous im- } \\
\text { munoglobulins } 0.4 \mathrm{~g} / \mathrm{kg} \text { arm; } 17 / 17 \text { in the intravenous im- } \\
\text { munoglobulins } 0.2 \mathrm{~g} / \mathrm{kg} \text { arm; } 17 / 18 \text { in the placebo arm }\end{array}$ \\
\hline Selective reporting (reporting bias) & High risk & Progression was not reported. \\
\hline Other bias & High risk & $\begin{array}{l}\text { Sustained disability progression confirmed at } 3 \text { months' follow- } \\
\text { up. Supported by the KBN (State Research } \\
\text { Committee). }\end{array}$ \\
\hline
\end{tabular}

\section{Likosky 1991}

\begin{tabular}{|c|c|}
\hline Methods & $\mathrm{RCT}$ \\
\hline Participants & $\begin{array}{l}\text { Age: } 18-60 \text { years; SPMS, PPMS or PRMS; progression } \geq 1.0 \text { EDSS in the year before } \\
\text { randomisation; disease duration } 1-29 \text { years; EDSS } 2.0-7.0\end{array}$ \\
\hline Interventions & $\begin{array}{l}\text { "short course" of cyclophosphamide } 500 \mathrm{mg} \text { administered intravenously five days per } \\
\text { week; (n. 22) } \\
\text { Folic acid ( } 1 \mathrm{mg} \text { ) administered intravenously five days per week (n. 21) }\end{array}$ \\
\hline Outcomes & Progression at 24 months \\
\hline
\end{tabular}

Copyright $\odot 2013$ The Cochrane Collaboration. Published by John Wiley \& Sons, Ltd. 


\section{Likosky 1991 (Continued)}

Notes

Funding: The Community Service Program of Kaiser Foundation Hospitals

\section{Risk of bias}

\begin{tabular}{|c|c|c|}
\hline Bias & Authors' judgement & Support for judgement \\
\hline $\begin{array}{l}\text { Random sequence generation (selection } \\
\text { bias) }\end{array}$ & Unclear risk & Not described \\
\hline Allocation concealment (selection bias) & Unclear risk & Not described \\
\hline $\begin{array}{l}\text { Blinding of participants and personnel } \\
\text { (performance bias) } \\
\text { All outcomes }\end{array}$ & Unclear risk & Not described \\
\hline $\begin{array}{l}\text { Blinding of outcome assessment (detection } \\
\text { bias) } \\
\text { All outcomes }\end{array}$ & Low risk & $\begin{array}{l}\text { "Evaluating physicians were unaware of the treatment status of the } \\
\text { patients they evaluated". Page } 1056\end{array}$ \\
\hline $\begin{array}{l}\text { Incomplete outcome data (attrition bias) } \\
\text { All outcomes }\end{array}$ & Low risk & $\begin{array}{l}\text { Losses to follow-up not included in the study analysis: treatment } \\
3 / 22(15 \%) \text {; placebo } 3 / 21(14 \%) \text {. Losses appear to be balanced } \\
\text { between the groups }\end{array}$ \\
\hline Selective reporting (reporting bias) & Low risk & The published report included expected efficacy outcome. \\
\hline Other bias & Unclear risk & $\begin{array}{l}\text { Definition of sustained disability progression not clearly re- } \\
\text { ported } \\
\text { "The research was supported in part by the Community Service Pro- } \\
\text { gram of Kaiser Foundation Hospitals. Evansville, Indiana, provided } \\
\text { cyclophosphamide as Cytoxan." Page } 1060\end{array}$ \\
\hline
\end{tabular}

Milanese 1993

\begin{tabular}{ll}
\hline Methods & RCT \\
\hline Participants & $\begin{array}{l}\text { Mean age: } 30 \text { years; definite RRMS, SPMS or PPMS; disease duration 5-15 years; EDSS } \\
2.5-6.5 ; \leq 1 \text { relapses in the } 2 \text { years before randomisation }\end{array}$ \\
\hline Interventions & $\begin{array}{l}\text { Azathioprine } 2.5 \mathrm{mg} / \mathrm{Kg} / \text { body weight oral daily for } 3 \text { years (n. 19) } \\
\text { Placebo (lactose) in identical form (50 mg tablets) for three years (n. 21) }\end{array}$ \\
\hline Outcomes & Relapses at 12,24 and 36 months. Progression at 24 and 36 months \\
\hline Notes & Funding: Wellcome Company. \\
\hline
\end{tabular}

Risk of bias 
Milanese 1993 (Continued)

\begin{tabular}{|c|c|c|}
\hline Bias & Authors' judgement & Support for judgement \\
\hline $\begin{array}{l}\text { Random sequence generation (selection } \\
\text { bias) }\end{array}$ & Unclear risk & "Wellcome Italia provided the randomisation code". Page 295 \\
\hline Allocation concealment (selection bias) & Unclear risk & $\begin{array}{l}\text { "Patients were allocated to azathioprineor placebo groups according } \\
\text { to a list of random code numbers". Page } 295\end{array}$ \\
\hline $\begin{array}{l}\text { Blinding of participants and personnel } \\
\text { (performance bias) } \\
\text { All outcomes }\end{array}$ & Unclear risk & $\begin{array}{l}\text { "azathioprineand placebo tablets in identical form were supplied } \\
\text { by Wellcome Company". Page } 295\end{array}$ \\
\hline $\begin{array}{l}\text { Blinding of outcome assessment (detection } \\
\text { bias) } \\
\text { All outcomes }\end{array}$ & Low risk & $\begin{array}{l}\text { "EDSS and relapses evaluated by the same blinded neurologist". } \\
\text { Page } 295\end{array}$ \\
\hline $\begin{array}{l}\text { Incomplete outcome data (attrition bias) } \\
\text { All outcomes }\end{array}$ & High risk & $\begin{array}{l}\text { Losses to follow-up not included in the study analysis: azathio- } \\
\text { prine } 26 \% \text {; placebo } 14 \%\end{array}$ \\
\hline Selective reporting (reporting bias) & Low risk & The published reports included all expected efficacy outcomes \\
\hline Other bias & High risk & $\begin{array}{l}\text { Sustained disability progression confirmed at } 3 \text { months' follow- } \\
\text { up. Funding: Wellcome Company }\end{array}$ \\
\hline
\end{tabular}

\section{Millefiorini 1997}

\begin{tabular}{ll}
\hline Methods & RCT \\
\hline Participants & $\begin{array}{l}\text { Age: } 18-45 \text { years; clinical or laboratory-supported definite RRMS; disease duration } 1 \text { - } \\
10 \text { years; EDSS } 2.0-5.0 ; \geq 1 \text { relapses in the } 2 \text { years before randomisation }\end{array}$ \\
\hline Interventions & $\begin{array}{l}12 \text { pulses of mitoxantrone } 8 \mathrm{mg} / \mathrm{m}^{2} / \text { body surface every month for } 1 \text { year (total dosage } \\
\text { of } 96 \mathrm{mg} / \mathrm{m}^{2} \text { of body surface over } 1 \text { year) }(\mathrm{n} .27) \\
\text { Placebo }(\mathrm{n} .24)\end{array}$ \\
\hline Outcomes & Relapses at 12 and 24 months, Progression at 24 months \\
\hline Notes & Funding: not reported \\
\hline
\end{tabular}

\section{Risk of bias}

\begin{tabular}{|c|c|c|}
\hline Bias & Authors' judgement & Support for judgement \\
\hline $\begin{array}{l}\text { Random sequence generation (selection } \\
\text { bias) }\end{array}$ & Unclear risk & Not described \\
\hline
\end{tabular}




\section{Millefiorini 1997 (Continued)}

\begin{tabular}{|c|c|c|}
\hline Allocation concealment (selection bias) & Low risk & $\begin{array}{l}\text { "Central allocation and the intravenous bag and tubing were black } \\
\text { to ensure no differences between the treatment groups. "Page } 154 .\end{array}$ \\
\hline $\begin{array}{l}\text { Blinding of participants and personnel } \\
\text { (performance bias) } \\
\text { All outcomes }\end{array}$ & High risk & $\begin{array}{l}\text { Treating physicians were not blinded. Unclear blinding of pa- } \\
\text { tients }\end{array}$ \\
\hline $\begin{array}{l}\text { Blinding of outcome assessment (detection } \\
\text { bias) } \\
\text { All outcomes }\end{array}$ & High risk & $\begin{array}{l}\text { "The interaction of the EDSS physicians with the patient was strictly } \\
\text { restricted to the neurological examination. The neurologist was not } \\
\text { allowed to talk with the patient about adverse events, or any other } \\
\text { issue which could potentially disclose the patient's treatment... The } \\
\text { assessment of exacerbations was monitored by treating physicians not } \\
\text { blinded to study treatment." Page } 154,157\end{array}$ \\
\hline $\begin{array}{l}\text { Incomplete outcome data (attrition bias) } \\
\text { All outcomes }\end{array}$ & Low risk & All randomised patients were included in the analysis. \\
\hline Selective reporting (reporting bias) & Low risk & The published reports included all expected efficacy outcomes \\
\hline Other bias & High risk & $\begin{array}{l}\text { Sustained disability progression confirmed at } 3 \text { months' follow- } \\
\text { up. It's unclear if this study was sponsored }\end{array}$ \\
\hline
\end{tabular}

\section{Miller 1961}

\begin{tabular}{ll}
\hline Methods & RCT \\
\hline Participants & $\begin{array}{l}\text { Mean age: } 33 \text { years; SPMS, or PRMS; mean disease duration 10-13 years; EDSS not } \\
\text { reported }\end{array}$ \\
\hline Interventions & $\begin{array}{l}\text { Prednisolone tablets } 15 \mathrm{mg} \text { oral daily for } 8 \text { months then } 10 \mathrm{mg} / \text { day for } 10 \text { months (n. } \\
29) \\
\text { Calcium aspirin } 9 \text { tablets }(54 \mathrm{~g}) \text { oral daily (n. 27) } \\
\text { Placebo corresponding number of "dummy" tablets (n. 30) }\end{array}$ \\
\hline Outcomes & Progression at 24 months \\
\hline Notes & No funding. \\
\hline
\end{tabular}

\section{Risk of bias}

\begin{tabular}{l|ll}
\hline Bias & Authors' judgement & Support for judgement \\
\hline $\begin{array}{l}\text { Random sequence generation (selection } \\
\text { bias) }\end{array}$ & Unclear risk & Not described \\
\hline Allocation concealment (selection bias) & Unclear risk & Not described
\end{tabular}




\section{Miller 1961 (Continued)}

\begin{tabular}{l|l|l}
\hline $\begin{array}{l}\text { Blinding of participants and personnel } \\
\text { (performance bias) } \\
\text { All outcomes }\end{array}$ & Unclear risk & Not clearly described \\
\hline $\begin{array}{l}\text { Blinding of outcome assessment (detection } \\
\text { bias) } \\
\text { All outcomes }\end{array}$ & Unclear risk & Not clearly described \\
\hline $\begin{array}{l}\text { Incomplete outcome data (attrition bias) } \\
\text { All outcomes }\end{array}$ & High risk & $\begin{array}{l}\text { Losses to follow-up: prednisolone 3/29 (10\%); “dummy" tablets } \\
1 / 30(3 \%) ; \text { calcium aspirin 3/27 (11\%) }\end{array}$ \\
\hline Selective reporting (reporting bias) & Low risk & The published report included the expected efficacy outcome. \\
\hline Other bias & Unclear risk & $\begin{array}{l}\text { Definition of sustained disability progression not clearly re- } \\
\text { ported }\end{array}$ \\
\hline
\end{tabular}

\section{Montalban 2009}

\begin{tabular}{ll}
\hline Methods & RCT \\
\hline Participants & $\begin{array}{l}\text { Age: } 18-65 \text { years; definite PPMS or “transitional” MS; mean disease duration } 11 \text { years; } \\
\text { EDSS } 3.0-7.0\end{array}$ \\
\hline Interventions & $\begin{array}{l}\text { IFNß }-1 \mathrm{~b} 250 \mu \mathrm{g} \text { subcutaneously every other day for 2 years (n. 36) } \\
\text { Placebo for } 2 \text { years (n. 37) }\end{array}$ \\
\hline Outcomes & Progression at 24 months \\
\hline Notes & Funding: SCHERING ESPANA S.A \\
\hline
\end{tabular}

\section{Risk of bias}

\begin{tabular}{|c|c|c|}
\hline Bias & Authors' judgement & Support for judgement \\
\hline $\begin{array}{l}\text { Random sequence generation (selection } \\
\text { bias) }\end{array}$ & Low risk & $\begin{array}{l}\text { "...Using a randomisation list. This randomization was performed } \\
\text { in blocks of } 6 \text { and for each treatment was assigned in a 1:1 ratio". } \\
\text { Page } 1196\end{array}$ \\
\hline Allocation concealment (selection bias) & Unclear risk & Not clearly described \\
\hline $\begin{array}{l}\text { Blinding of participants and personnel } \\
\text { (performance bias) } \\
\text { All outcomes }\end{array}$ & Low risk & $\begin{array}{l}\text { "All personnel at the study site (dispensing pharmacists, treating } \\
\text { physicians and participants) were blinded to the outcome assessment } \\
\text { and study drug." Page } 1197\end{array}$ \\
\hline $\begin{array}{l}\text { Blinding of outcome assessment (detection } \\
\text { bias) }\end{array}$ & Low risk & $\begin{array}{l}\text { "EDSS physicians were blinded to the outcome assessment and study } \\
\text { drug." Page } 1197\end{array}$ \\
\hline
\end{tabular}

All outcomes 
Montalban 2009 (Continued)

\begin{tabular}{|c|c|c|}
\hline $\begin{array}{l}\text { Incomplete outcome data (attrition bias) } \\
\text { All outcomes }\end{array}$ & Low risk & $\begin{array}{l}3 \text { patients dropped out the study: } 1 \text { in the IFN } \beta-1 b \text { arm; } 2 \text { in } \\
\text { the placebo arm }\end{array}$ \\
\hline Selective reporting (reporting bias) & Low risk & The published report included the expected efficacy outcome. \\
\hline Other bias & High risk & $\begin{array}{l}\text { "An external company (MDS Pharma Services Espana) named and } \\
\text { funded by the study sponsor produced the statistical analyses under } \\
\text { supervision from the principal investigator". }\end{array}$ \\
\hline
\end{tabular}

\section{MSCRG 1996}

Methods

RCT

Participants

Age: 18-55 years; definite RRMS; EDSS 1-3.5; disease duration $\geq 1$ year; $\geq 2$ relapses in the 3 years before randomisation; no relapses for at least 2 months before randomisation

Interventions $\quad$ IFNß-1a (Avonex) $30 \mu \mathrm{g}$ intramuscular weekly (n. 158).

Placebo (n. 143).

Outcomes

Relapses at 12 and 24 months. Progression at 24 months.

Notes

Funding: Biogen, Inc, Cambridge, MA

\section{Risk of bias}

\begin{tabular}{|c|c|c|}
\hline Bias & Authors' judgement & Support for judgement \\
\hline $\begin{array}{l}\text { Random sequence generation (selection } \\
\text { bias) }\end{array}$ & Unclear risk & $\begin{array}{l}\text { "Randomisation performed at statistical centre of Buffalo General } \\
\text { Hospital, one of the participating centres (biased coin assignment } \\
\text { used for sequence generation". Page } 286\end{array}$ \\
\hline Allocation concealment (selection bias) & Unclear risk & $\begin{array}{l}\text { "schedule sent to each clinical centre, included patients were sequen- } \\
\text { tially assigned the next ID number from the schedule." Page } 286\end{array}$ \\
\hline $\begin{array}{l}\text { Blinding of participants and personnel } \\
\text { (performance bias) } \\
\text { All outcomes }\end{array}$ & Low risk & $\begin{array}{l}\text { "Personnel and participants were blinded to treatment status." Page } \\
286\end{array}$ \\
\hline $\begin{array}{l}\text { Blinding of outcome assessment (detection } \\
\text { bias) } \\
\text { All outcomes }\end{array}$ & Low risk & "Evaluating physicians were blinded to treatment status." Page 286 \\
\hline
\end{tabular}

Incomplete outcome data (attrition bias) High risk All outcomes

The study stopped early for benefit without a formal-stopping rule. $73(46 \%)$ of 158 patients in the treatment group and 56 (39\%) of 143 controls had not completed the scheduled 2 years of follow-up. At 2 years' follow-up primary outcomes were available for only $57 \%$ of randomised participants 
MSCRG 1996 (Continued)

\begin{tabular}{|c|c|c|}
\hline Selective reporting (reporting bias) & Low risk & Expected efficacy outcomes were reported. \\
\hline Other bias & High risk & $\begin{array}{l}\text { "Supported by National Institutes of Health, National Institute of } \\
\text { NeurologicalDisorders and Stroke (NINDS) and Biogen, Inc, Cam- } \\
\text { bridge, MA. Personnel of the study sponsor (Biogen) were involved } \\
\text { in the conduct and data analysis". Page } 293\end{array}$ \\
\hline
\end{tabular}

NASP 2004

Methods

RCT

Participants

Age 18-65 years, clinically definite SPMS of at least 2 years' duration; $\geq 1.0$ EDSS increase in the 2 years before randomisation; $\geq 1.0$ relapses followed by progressive deterioration sustained for at least 6 months; EDSS 3.0-6.5

Interventions

IFNß -1b (Betaseron) $250 \mu \mathrm{g}$ subcutaneously every other day (n. 317)

INFß -1b (Betaseron) $160 \mu \mathrm{g} / \mathrm{m}^{2}$ body surface area (mean administered dose $220 \mu \mathrm{g}$ ) every other day (n. 314)

Placebo (n. 308)

Outcomes

Notes
Relapses at 36 months. Progression at 36 months.

Funding: Berlex Laboratories (Richmond, CA)

\section{Risk of bias}

\section{Bias}

Random sequence generation (selection Low risk bias)

\section{Authors' judgement Support for judgement}

"The randomisation schedule was generated by the Biostatistics and Data Management Group of Berlex Laboratories (Richmond, CA) using an SAS program (Cary, NC)... Each block allocated 2 subjects to fixed-dose Betaseron, 2 to Body Surface Area (BSA)-adjusted Betaseron, 1 to fixed placebo, and 1 to BSA-adjusted placebo. Each site received an adequate number of blocks, based on projected subject recruitment, to ensure sequential subject numbering within each site." Page 1789

Allocation concealment (selection bias) Low risk

"The biostatistician and supporting programmers were the only individuals with access to the randomisation codes" (FDA page 9). "The active study drug was indistinguishable from placebo in appearance, smell and color, and labels and packages for active study agent and placebo were indistinguishable" (FDA page 9)

Blinding of participants and personnel Low risk (performance bias)

All outcomes

"All sponsor personnel directly involved in the conduct of the study, investigators, and subjects remained blinded to subject treatment assignment throughout the study". (FDA page 9) 
NASP 2004 (Continued)

\begin{tabular}{|c|c|c|}
\hline $\begin{array}{l}\text { Blinding of outcome assessment (detection } \\
\text { bias) } \\
\text { All outcomes }\end{array}$ & Low risk & $\begin{array}{l}\text { "Investigators remained blinded to subject treatment assignment } \\
\text { throughout the study". (FDA page 9) }\end{array}$ \\
\hline $\begin{array}{l}\text { Incomplete outcome data (attrition bias) } \\
\text { All outcomes }\end{array}$ & High risk & $\begin{array}{l}\text { "The study had ended prematurely based on the results of a planned } \\
\text { interim analysis indicating that "continuing the trial was unlikely } \\
\text { to change the results". The study initiated in August 2, 1995, in- } \\
\text { terrupted November 22, } 1999 \text {. The last patient enrolled on April } \\
1,1997 . \text { The final patient visit occurred on November 15, 1999". } \\
\text { (FDA report page 21). "Only } 72 \% \text { of randomised patients com- } \\
\text { pleted } 33 \text { months or more on study and could be included in anal- } \\
\text { ysis" (FDA } 2001 \text { page 26). }\end{array}$ \\
\hline
\end{tabular}

\begin{tabular}{l|l|l}
\hline Selective reporting (reporting bias) & Unclear risk & The published reports included relapses and progression at 36
\end{tabular} months (no data at 24 months)

\begin{tabular}{lll}
\hline Other bias & High risk & Funding: Berlex Laboratories (Richmond, CA).
\end{tabular}

\section{OWIMS 1999}

\begin{tabular}{|c|c|c|}
\hline Methods & \multicolumn{2}{|l|}{ RCT } \\
\hline Participants & \multicolumn{2}{|c|}{$\begin{array}{l}\text { Age: } 18-50 \text { years; clinical or laboratory-supported definite RRMS; EDSS } 0-5.0 \text {; disease } \\
\text { duration } \geq 1 \text { year; } \geq 1 \text { relapses in the } 2 \text { years before randomisation; no relapses for at } \\
\text { least } 2 \text { months before randomisation }\end{array}$} \\
\hline Interventions & \multicolumn{2}{|c|}{$\begin{array}{l}\text { IFNß -1a (Rebif) } 22 \mu \mathrm{g} \text { subcutaneous three times/week for } 48 \text { weeks (n. 95) } \\
\text { IFNß -1a (Rebif) } 44 \mu \mathrm{g} \text { subcutaneous three times/week for } 48 \text { weeks (n. 98) } \\
\text { Placebo (human albumin and mannitol) for } 48 \text { weeks (n. 100) }\end{array}$} \\
\hline Outcomes & \multicolumn{2}{|l|}{ Relapses at 12 months } \\
\hline Notes & \multicolumn{2}{|c|}{ Funding: Ares-Serono International SA, Geneva, Switzerland } \\
\hline \multicolumn{3}{|l|}{ Risk of bias } \\
\hline Bias & Authors' judgement & Support for judgement \\
\hline $\begin{array}{l}\text { Random sequence generation (selection } \\
\text { bias) }\end{array}$ & Low risk & $\begin{array}{l}\text { "Randomisation performed at Corporate Biometrics Department of } \\
\text { Ares-Serono (computer-generated list)." Page } 680\end{array}$ \\
\hline Allocation concealment (selection bias) & Unclear risk & $\begin{array}{l}\text { "Sealed envelopes were used but it was unclear whether envelopes } \\
\text { were sequentailly numbered and opaque." Page } 680\end{array}$ \\
\hline $\begin{array}{l}\text { Blinding of participants and personnel } \\
\text { (performance bias) } \\
\text { All outcomes }\end{array}$ & Low risk & "Participants were blinded to treatment" Page 681 \\
\hline
\end{tabular}


OWIMS 1999 (Continued)

\begin{tabular}{ll|l}
\hline $\begin{array}{l}\text { Blinding of outcome assessment (detection } \\
\text { bias) } \\
\text { All outcomes }\end{array}$ & Low risk & $\begin{array}{l}\text { "The evaluating physician was responsible for neurologic assessments } \\
\text { and remained unaware of adverse event profiles and any changes in } \\
\text { safety assessments." Page } 681\end{array}$ \\
\hline $\begin{array}{l}\text { Incomplete outcome data (attrition bias) } \\
\text { All outcomes }\end{array}$ & High risk & $\begin{array}{l}\text { Losses to follow-up: treatment arms } 13 \% \text { and } 8 \% \text {; placebo arm } \\
\text { 3\%. Reason for missing data was likely related to outcome with } \\
\text { imbalance in numbers across intervention groups }\end{array}$ \\
\hline Selective reporting (reporting bias) & High risk & Only relapses at 12 months were reported. \\
\hline Other bias & High risk & $\begin{array}{l}\text { Sponsored by Ares-Serono International SA, Geneva, Switzer- } \\
\text { land }\end{array}$ \\
\hline
\end{tabular}

Pohlau 2007

\begin{tabular}{|c|c|c|}
\hline \multicolumn{3}{|l|}{ Methods } \\
\hline Participants & \multicolumn{2}{|c|}{$\begin{array}{l}\text { Age: } 18-65 \text { years; SPMS, or PPMS; progression } \geq 0.5 \text { EDSS point in the year before } \\
\text { randomisation; disease duration }>2 \text { years; EDSS } 3.0-7.0\end{array}$} \\
\hline Interventions & \multicolumn{2}{|c|}{$\begin{array}{l}\text { IVIg } 0.4 \mathrm{gm} / \mathrm{kg} \text { body weight intravenous monthly (n. 116). } \\
\text { Placebo (n. 115). }\end{array}$} \\
\hline Outcomes & \multicolumn{2}{|c|}{ Progression at 24 months. } \\
\hline Notes & \multicolumn{2}{|c|}{ Fundings: Novartis Pharma GmbH and ZLB Behring. } \\
\hline \multicolumn{3}{|l|}{ Risk of bias } \\
\hline Bias & Authors' judgement & Support for judgement \\
\hline $\begin{array}{l}\text { Random sequence generation (selection } \\
\text { bias) }\end{array}$ & Low risk & $\begin{array}{l}\text { "Randomisation was performed by the Biometric Department No- } \\
\text { vartis Germany using a scheme, which provided balanced blocks of } \\
\text { patient numbers for both treatment groups and the two diagnostic } \\
\text { layers." Page } 1109\end{array}$ \\
\hline Allocation concealment (selection bias) & Unclear risk & Not clearly described. Only “randomly assigned” Page 1109 \\
\hline $\begin{array}{l}\text { Blinding of participants and personnel } \\
\text { (performance bias) } \\
\text { All outcomes }\end{array}$ & Unclear risk & $\begin{array}{l}\text { Not clearly described. Only "intravenous immunoglobulinsand } \\
\text { placebo could not visually be distinguished." Page } 1109\end{array}$ \\
\hline $\begin{array}{l}\text { Blinding of outcome assessment (detection } \\
\text { bias) } \\
\text { All outcomes }\end{array}$ & Unclear risk & Not described \\
\hline
\end{tabular}


Pohlau 2007 (Continued)

\begin{tabular}{|c|c|c|}
\hline $\begin{array}{l}\text { Incomplete outcome data (attrition bias) } \\
\text { All outcomes }\end{array}$ & Unclear risk & $\begin{array}{l}\text { "113 patients (49\%) completed the } 112 \text { weeks of the study, and } 118 \\
(51 \%) \text { discontinued their participation prematurely." Page } 1110 \\
\text {. Follow-up of the participants who discontinued participation } \\
\text { was not reported }\end{array}$ \\
\hline Selective reporting (reporting bias) & Low risk & Progression at 24 months is the expected efficacy outcome. \\
\hline Other bias & High risk & $\begin{array}{l}\text { Sustained disability progression confirmed at } 16 \text { weeks' follow- } \\
\text { up. Supported by Novartis Pharma GmbH, Nürnberg, Ger- } \\
\text { many and ZLB Behring, Bern Switzerland }\end{array}$ \\
\hline
\end{tabular}

\section{PRISMS 1998}

\begin{tabular}{ll}
\hline Methods & RCT \\
\hline Participants & $\begin{array}{l}\text { Age: } 28-41 \text { years; clinical or laboratory-supported definite RRMS; EDSS 0-5.0; disease } \\
\text { duration } \geq 1 \text { year; at least } 2 \text { relapses in the } 2 \text { years before randomisation }\end{array}$ \\
\hline Interventions & $\begin{array}{l}\text { IFNß }-1 \text { a (Rebif) } 22 \mu \mathrm{g} \text { subcutaneous three times/week for } 2 \text { years (n. 189) } \\
\text { IFNß }-1 \text { a (Rebif) } 44 \mu \text { g subcutaneous three times/week for } 2 \text { years (n. 184) } \\
\text { Placebo (unspecified) for } 2 \text { years (n. 187) }\end{array}$ \\
\hline Outcomes & Relapses at 12 and 24 months. Progression at 24 months \\
\hline Notes & Fundng: Ares-Serono International SA, Geneva, Switzerland \\
\hline
\end{tabular}

\section{Risk of bias}

\section{Bias}

Random sequence generation (selection Low risk bias)

\section{Authors' judgement Support for judgement}

"Randomisation at Corporate Biometrics Department of AresSerono (computer-generated list, stratified by centre, equal allocation of the treatment groups by a block size of 6)." Page 1499

Allocation concealment (selection bias) Low risk

"The study drug was packed accordingly to the randomisation list and delivered to the centres so that treatment allocation remained concealed'. Page 1499

Blinding of participants and personnel Low risk (performance bias)

"All personnel involved in the study were unaware of treatment allocation". Page 1499

All outcomes

Blinding of outcome assessment (detection Low risk bias)

All outcomes
"All personnel involved in the study were unaware of treatment allocation. All injection sites were covered up at neurological examinations to ensure that masking was not compromised because of local reactions". Page 1499 
PRISMS 1998 (Continued)

\begin{tabular}{|c|c|c|}
\hline $\begin{array}{l}\text { Incomplete outcome data (attrition bias) } \\
\text { All outcomes }\end{array}$ & Low risk & $\begin{array}{l}\text { Losses to follow-up excluded from study analysis: treatment arms } \\
6 \% \text { and 3\%; placebo arm } 5 \%\end{array}$ \\
\hline Selective reporting (reporting bias) & Low risk & The published report included all expected efficacy outcomes \\
\hline Other bias & High risk & $\begin{array}{l}\text { "Sustained" disability progression was confirmed at } 3 \text { months' } \\
\text { follow-up. Ares-Serono was involved in the trial }\end{array}$ \\
\hline
\end{tabular}

REGARD 2008

\begin{tabular}{ll}
\hline Methods & RCT \\
\hline Participants & $\begin{array}{l}\text { Mean age: } 37 \text { years; clinical or laboratory-supported definite RRMS; EDSS 0-5.5; mean } \\
\text { disease duration } 6 \text { years; } \geq 1 \text { relapses in the year before randomisation }\end{array}$ \\
\hline Interventions & $\begin{array}{l}\text { IFNß }-1 \text { a (Rebif) } 44 \mu \mathrm{g} \text { subcutaneous three times/week for } 96 \text { weeks (n. 386) } \\
\text { Glatiramer acetate } 20 \mathrm{mg} \text { subcutaneous every day for } 96 \text { weeks (n. 378) }\end{array}$ \\
\hline Outcomes & Relapses at 24 months. Progression at 24 months \\
\hline Notes & Funding: EMD Serono and Pfi zer \\
\hline
\end{tabular}

\section{Risk of bias}

\section{Bias}

Random sequence generation (selection Low risk bias)

Allocation concealment (selection bias)

$$
\text { Unclear risk }
$$

Blinding of participants and personnel High risk (performance bias)

All outcomes

Blinding of outcome assessment (detection Low risk bias)

All outcomes

\begin{tabular}{ll}
\hline $\begin{array}{l}\text { Incomplete outcome data (attrition bias) } \\
\text { All outcomes }\end{array}$ & Low risk \\
\hline
\end{tabular}

Selective reporting (reporting bias) Low risk

\begin{abstract}
"The physicians who assessed patients ... were blinded to treatment and communicated with the patients only as needed to complete the EDSS, Kurtzke functional scale (KFS), and relapse assessments. Patients were asked not to discuss their treatment with the assessing physician and they covered their injection sites." Page 904
\end{abstract}

Losses to follow-up: IFNß -1a 20/386 (5\%); glatiramer acetate $5 / 378(1 \%)$

The published report included all expected efficacy outcomes 
REGARD 2008 (Continued)

\begin{tabular}{|c|c|c|}
\hline Other bias & High risk & $\begin{array}{l}\text { "The study protocol was drafted and developed by the study } \\
\text { sponsors, EMD Serono and Pfi zer, in conjunction with the in- } \\
\text { vestigator steering committee. Data management and analysis } \\
\text { were done by the study sponsors." Page } 907\end{array}$ \\
\hline
\end{tabular}

SENTINEL 2006

\begin{tabular}{ll}
\hline Methods & RCT \\
\hline Participants & $\begin{array}{l}\text { Age: } 18-55 \text { years; clinical definite RRMS; disease duration 1-34 years; EDSS 0-5.0; } \geq 1 \\
\text { relapses in the year before randomisation }\end{array}$ \\
\hline Interventions & $\begin{array}{l}\text { Natalizumab } 300 \text { mg intravenous monthly and IFNß-1a (Avonex) } 30 \mu \mathrm{g} \text { intramuscular } \\
\text { weekly for } 116 \text { weeks.(n. 589) } \\
\text { Placebo and IFNß-1a (Avonex) } 30 \mu \mathrm{g} \text { intramuscular weekly for } 116 \text { weeks. (n. 582) }\end{array}$ \\
\hline Outcomes & Relapses at 12 and 24 months. Progression at 24 months \\
\hline Notes & Funding: Biogen Idec, Inc. and Elan Pharmaceutical \\
\hline
\end{tabular}

\section{Risk of bias}

Bias

Random sequence generation (selection Low risk bias)

\section{Authors' judgement Support for judgement}

"Randomization was stratified according to study site in blocks of four (two active and two placebo) with the use of a computergenerated schedule and a multidigit identification number". Page 912

\begin{tabular}{|c|c|c|}
\hline Allocation concealment (selection bias) & Low risk & “An interactive voice-response system was used". Page 912 \\
\hline $\begin{array}{l}\text { Blinding of participants and personnel } \\
\text { (performance bias) } \\
\text { All outcomes }\end{array}$ & Low risk & $\begin{array}{l}\text { "All study personnel, patients, sponsor personnel involved in the } \\
\text { conduct of the study, and members of the investigator advi- } \\
\text { sory committee were blinded to the treatment assignments through- } \\
\text { out the study." Page } 912 \text { "The treating neurologists were responsible } \\
\text { for all patient care, including the management of adverse events and } \\
\text { relapses of multiple sclerosis". Page } 913\end{array}$ \\
\hline $\begin{array}{l}\text { Blinding of outcome assessment (detection } \\
\text { bias) } \\
\text { All outcomes }\end{array}$ & Unclear risk & $\begin{array}{l}\text { "Examining neurologists performed the EDSS and neurologic ex- } \\
\text { aminations but were otherwise not involved in the patients' medical } \\
\text { care." Page } 913\end{array}$ \\
\hline
\end{tabular}

Incomplete outcome data (attrition bias) Low risk All outcomes

$516 / 589(88 \%)$ in the natalizumab + IFNß-1a group and 487/ $582(84 \%)$ in the placebo+ IFNß-1a group completed the $120-$ week study

Selective reporting (reporting bias) Low risk
The published report included all expected efficacy outcomes 
SENTINEL 2006 (Continued)

\begin{tabular}{l|l|}
\hline Other bias & $\begin{array}{l}\text { Sustained disability progression confirmed at } 3 \text { months' follow- } \\
\text { up }\end{array}$ \\
$\begin{array}{l}\text { The study protocol was developed by the investigator advisory } \\
\text { committee and the sponsors (Biogen Idec and Elan Pharmaceu- } \\
\text { ticals). Data were analyzed by the sponsor. Relapses were assessed } \\
\text { also as adverse events }\end{array}$ \\
\hline
\end{tabular}

\section{SPECTRIMS 2001}

\begin{tabular}{ll} 
Methods & RCT \\
\hline Participants & $\begin{array}{l}\text { Age: } 18-55 \text { years; clinical definite SPMS; progression } \geq 1 \text { EDSS over the previous } 2 \\
\text { years, with or without superimposed relapses before randomisation; EDSS 3.0-6.5; mean } \\
\text { disease duration } 14 \text { years }\end{array}$ \\
\hline
\end{tabular}

Interventions

IFNß -1a (Rebif) $22 \mu \mathrm{g}$ subcutaneous three times/week for 3 years (n. 209)

IFNß -1a (Rebif) $44 \mu \mathrm{g}$ subcutaneous three times/week for 3 years (n. 204)

Placebo (unspecified) for 3 years (n. 205)

Outcomes Progression at 24 and 36 months

Notes Funding: Serono International, Geneva, Switzerland

\section{Risk of bias}

Bias

Random sequence generation (selection Low risk bias)

Allocation concealment (selection bias) Unclear risk

Blinding of participants and personnel Unclear risk (performance bias)

All outcomes

Blinding of outcome assessment (detection Low risk bias)

All outcomes
Authors' judgement Support for judgement

"Computer generated randomisation list provided by Serono, stratified by center; treatments were equally allocated with a block size of six”. Page 1497

"The block size was not revealed to the investigators. The manufacturer labelled containers of study medication with patient identification numbers based on the randomisation list, and patients received the medication labelled with their numbers." Page 1497

"A treating physician supervised drug administration, monitored safety, and managed adverse events". Page 1497

"A separate evaluating physician conducted neurologic assessments and followed-up exacerbations. Patients were instructed to cover injection sites and to discuss only neurologic matters during neurologic evaluations. Clinical and neurologic data were recorded in separate binders." Page 1497 
SPECTRIMS 2001 (Continued)

\begin{tabular}{|c|c|c|}
\hline $\begin{array}{l}\text { Incomplete outcome data (attrition bias) } \\
\text { All outcomes }\end{array}$ & Low risk & $\begin{array}{l}195 / 209(93 \%) \text { in the IFNß - 1a } 22 \mu \mathrm{g} \text { group, } 190 / 204(93 \%) \\
\text { in the IFNß - 1a } 44 \mu \mathrm{g} \text { group and } 186 / 205(91 \%) \text { in the placebo } \\
\text { group completed } 3 \text { years' follow-up }\end{array}$ \\
\hline Selective reporting (reporting bias) & Low risk & The published report included all expected efficacy outcomes \\
\hline Other bias & High risk & $\begin{array}{l}\text { Sustained disability progression confirmed at } 3 \text { months' follow- } \\
\text { up. Serono Biometrics (Geneva) performed statistical analysis }\end{array}$ \\
\hline
\end{tabular}

Wolinsky 2007

\begin{tabular}{ll}
\hline Methods & RCT \\
\hline Participants & $\begin{array}{l}\text { Age: } 30-65 \text { years; definite chronic progressive MS; EDSS 3.0-6.5; progression } \geq 6 \\
\text { months; } \leq 2 \text { relapses in the } 2 \text { years before randomisation }\end{array}$ \\
\hline Interventions & $\begin{array}{l}\text { Glatiramer acetate } 20 \text { mg subcutaneous every day for } 3 \text { years (n. 627) } \\
\text { Placebo (unspecified) for } 3 \text { years (n. 316) }\end{array}$ \\
\hline Outcomes & Progression at 24 months \\
\hline Notes & Funding: Teva Pharmaceutical \\
\hline
\end{tabular}

Risk of bias

\begin{tabular}{|c|c|c|}
\hline Bias & Authors' judgement & Support for judgement \\
\hline $\begin{array}{l}\text { Random sequence generation (selection } \\
\text { bias) }\end{array}$ & Unclear risk & Not described \\
\hline Allocation concealment (selection bias) & Unclear risk & Not described \\
\hline $\begin{array}{l}\text { Blinding of participants and personnel } \\
\text { (performance bias) } \\
\text { All outcomes }\end{array}$ & Unclear risk & $\begin{array}{l}\text { "All patients were attended by a treating neurologist and an ex- } \\
\text { amining neurologist who were blinded to treatment. The treating } \\
\text { neurologist supervised drug administration, recorded and treated } \\
\text { adverse events, and coordinated MRI testing." Page } 16\end{array}$ \\
\hline $\begin{array}{l}\text { Blinding of outcome assessment (detection } \\
\text { bias) } \\
\text { All outcomes }\end{array}$ & Unclear risk & “... examining neurologist was blinded to treatment." Page 16 \\
\hline $\begin{array}{l}\text { Incomplete outcome data (attrition bias) } \\
\text { All outcomes }\end{array}$ & Unclear risk & $\begin{array}{l}\text { Study stopped early for futility. } 376 / 627(60 \%) \text { of participants in } \\
\text { the glatiramer acetate group and } 186 / 315(59 \%) \text { in the placebo } \\
\text { group had received study drugs for } 24 \text { months. Insufficient in- } \\
\text { formation to judge whether withdrawals and lost to follow-up } \\
\text { were included in data analysis }\end{array}$ \\
\hline
\end{tabular}


Wolinsky 2007 (Continued)

\begin{tabular}{|c|c|c|}
\hline Selective reporting (reporting bias) & Unclear risk & Progression at 24 months was reported. \\
\hline Other bias & High risk & $\begin{array}{l}\text { Sustained disability progression confirmed at } 3 \text { months' follow- } \\
\text { up. Funding: Teva Pharmaceutical }\end{array}$ \\
\hline
\end{tabular}

Characteristics of excluded studies [ordered by study ID]

\begin{tabular}{|c|c|}
\hline Study & Reason for exclusion \\
\hline Arnason 1999 & Study on TNF neutralization (Lenercept). \\
\hline Barkhof 2003 & ETOMS trial MRI subgroup analysis. \\
\hline Baum 2006 & $\begin{array}{l}\text { Study evaluating two formulations of interferon } b \text { (IFNbeta-1b-G or the refrigeration-free formulation } \\
\text { (IFNbeta-1b-M) without a control group }\end{array}$ \\
\hline BENEFIT 2006 & Study on interferon beta $1 \mathrm{~b}$ for clinically isolated syndromes (CIS) \\
\hline Boiko 2001 & Trial on short course of antibodies to IFN gamma or antibodies to tumour necrosis factor alpha \\
\hline Burton 2009 & A Cochrane review on oral versus Intravenous steroids for treatment of relapses in multiple sclerosis \\
\hline CHAMPS 2000 & Study on interferon beta 1a for clinically isolated syndromes (CIS) \\
\hline Christodoulou 2006 & Study on donepezil. \\
\hline Clanet 2002 & A dose-comparison study of interferon beta-1a without a control group \\
\hline Durelli 1994 & Study on interferon alfa for multiple sclerosis. \\
\hline ETOMS 2001 & Study on interferon beta 1a for clinically isolated syndromes (CIS) \\
\hline Fernandez 2002 & Prospective study evaluating combination therapy with interferon beta $1 \mathrm{~b}$ and azathioprine in MS \\
\hline Filippi 2004 & ETOMS trial MRI subgroup analysis. \\
\hline Filippi 2006 & Study on oral glatiramer acetate for multiple sclerosis. \\
\hline GLANCE 2009 & Active treatment with natalizumab was confounded by glatiramer acetate \\
\hline Goodkin 2000 & Study on complex of human leukocyte antigen-DR2 with myelin basic protein84-102 \\
\hline Hauser 1983 & Active treatment with cyclophosphamide was confounded by other treatments \\
\hline
\end{tabular}


(Continued)

\begin{tabular}{|c|c|}
\hline Hoogervorst 2002 & A phase II study evaluating the safety, tolerability and MRI effects of oral interferon beta-1a \\
\hline Labetouelle 2001 & Review about CHAMPS study. \\
\hline Liu 2010 & A Cochrane review on daclizumab for multiple sclerosis. \\
\hline Myhr 1999 & Study on interferon alfa for multiple sclerosis. \\
\hline Patti 1999 & Study on natural interferon beta derived from human fibroblasts (Ares-Serono@) \\
\hline Rio 2007 & Open label, non-randomised, observational study. \\
\hline Skurkovich 2001 & A trial comparing antibodies to TNF-a, to IFN- $\gamma$ and placebo. \\
\hline Steultjens 2003 & A Cochrane review on occupational therapy for multiple sclerosis \\
\hline Tejani 2010 & A Cochrane review on carnitine for fatigue in multiple sclerosis \\
\hline Tubridy 1999 & Study on natalizumab with a dosage of $3 \mathrm{mg} / \mathrm{kg}$. \\
\hline Van de Wyngaert 2001 & Study on mitoxantrone in which participants' inclusion criteria were not described \\
\hline Wender 1988 & Active treatment with cyclophosphamide was confounded by other treatments \\
\hline Zavalishin 2003 & Multicentre non-randomised study evaluating the effect of interferon alfa \\
\hline Zivadinov 2001 & A dose-comparison trial of long-term corticosteroids without a control group \\
\hline
\end{tabular}


DATA AND ANALYSES

Comparison 1. Comparisons for relapse over 12 months

\begin{tabular}{|c|c|c|c|c|}
\hline Outcome or subgroup title & $\begin{array}{l}\text { No. of } \\
\text { studies }\end{array}$ & $\begin{array}{c}\text { No. of } \\
\text { participants }\end{array}$ & Statistical method & Effect size \\
\hline $\begin{array}{l}1 \text { Relapse over } 12 \text { months in MS } \\
\text { of all types }\end{array}$ & 21 & & Odds Ratio (IV, Random, 95\% CI) & Subtotals only \\
\hline $\begin{array}{l}1.1 \text { IFNß-1b (Betaseron) } \\
\text { versus placebo }\end{array}$ & 1 & 25 & Odds Ratio (IV, Random, 95\% CI) & $0.6[0.10,3.49]$ \\
\hline $\begin{array}{l}1.2 \text { IFNß-1a (Avonex) versus } \\
\text { placebo }\end{array}$ & 1 & 301 & Odds Ratio (IV, Random, 95\% CI) & $0.72[0.45,1.14]$ \\
\hline $\begin{array}{l}1.3 \text { IFNß-1a (Rebif) versus } \\
\text { placebo }\end{array}$ & 2 & 853 & Odds Ratio (IV, Random, 95\% CI) & $0.66[0.25,1.78]$ \\
\hline $\begin{array}{l}1.4 \text { Glatiramer acetate versus } \\
\text { placebo }\end{array}$ & 2 & 289 & Odds Ratio (IV, Random, 95\% CI) & $0.34[0.06,2.05]$ \\
\hline $\begin{array}{l}1.5 \text { Natalizumab versus } \\
\text { placebo }\end{array}$ & 1 & 942 & Odds Ratio (IV, Random, 95\% CI) & $0.38[0.28,0.51]$ \\
\hline $\begin{array}{l}\text { 1.6 Mitoxantrone versus } \\
\text { placebo }\end{array}$ & 1 & 51 & Odds Ratio (IV, Random, 95\% CI) & $0.14[0.04,0.48]$ \\
\hline $\begin{array}{l}1.7 \text { Azathioprine versus } \\
\text { placebo }\end{array}$ & 4 & 547 & Odds Ratio (IV, Random, 95\% CI) & $0.63[0.44,0.89]$ \\
\hline $\begin{array}{l}1.8 \text { Immunoglobulins versus } \\
\text { placebo }\end{array}$ & 4 & 537 & Odds Ratio (IV, Random, 95\% CI) & $0.56[0.20,1.60]$ \\
\hline $\begin{array}{l}\text { 1.9 Corticosteroids versus } \\
\text { placebo }\end{array}$ & 1 & 36 & Odds Ratio (IV, Random, 95\% CI) & $0.46[0.12,1.84]$ \\
\hline $\begin{array}{l}1.10 \text { IFNß-1a (Avonex) versus } \\
\text { IFNß-1b (Betaseron) }\end{array}$ & 1 & 188 & Odds Ratio (IV, Random, 95\% CI) & $1.53[0.86,2.72]$ \\
\hline $\begin{array}{l}\text { 1.11 IFNß-1a (Rebif) versus } \\
\text { IFNß-1a (Avonex) }\end{array}$ & 1 & 677 & Odds Ratio (IV, Random, 95\% CI) & $0.79[0.58,1.07]$ \\
\hline $\begin{array}{l}1.12 \text { Natalizumab versus } \\
\text { IFNß-1a (Avonex) }\end{array}$ & 1 & 1171 & Odds Ratio (IV, Random, 95\% CI) & $0.40[0.32,0.51]$ \\
\hline $\begin{array}{l}1.13 \text { Corticosteroids versus } \\
\text { Mitoxantrone }\end{array}$ & 1 & 42 & Odds Ratio (IV, Random, 95\% CI) & $4.0[1.11,14.43]$ \\
\hline $\begin{array}{l}2 \text { Relapse over } 12 \text { months in } \\
\text { relapsing-remitting MS }\end{array}$ & 16 & 4806 & Odds Ratio (M-H, Fixed, 95\% CI) & $0.55[0.49,0.62]$ \\
\hline $\begin{array}{l}2.1 \text { IFNß-1b (Betaseron) } \\
\text { versus placebo }\end{array}$ & 1 & 25 & Odds Ratio (M-H, Fixed, 95\% CI) & $0.6[0.10,3.49]$ \\
\hline $\begin{array}{l}\text { 2.2 IFNß-1a (Avonex) versus } \\
\text { placebo }\end{array}$ & 1 & 301 & Odds Ratio (M-H, Fixed, 95\% CI) & $0.72[0.45,1.14]$ \\
\hline $\begin{array}{l}2.3 \text { IFNß-1a (Rebif) versus } \\
\text { placebo }\end{array}$ & 2 & 853 & Odds Ratio (M-H, Fixed, 95\% CI) & $0.59[0.43,0.81]$ \\
\hline $\begin{array}{l}2.4 \text { Glatiramer acetate versus } \\
\text { placebo }\end{array}$ & 2 & 289 & Odds Ratio (M-H, Fixed, 95\% CI) & $0.59[0.37,0.93]$ \\
\hline $\begin{array}{l}2.5 \text { Natalizumab versus } \\
\text { placebo }\end{array}$ & 1 & 942 & Odds Ratio (M-H, Fixed, 95\% CI) & $0.38[0.28,0.51]$ \\
\hline $\begin{array}{l}\text { 2.6 Mitoxantrone versus } \\
\text { placebo }\end{array}$ & 1 & 51 & Odds Ratio (M-H, Fixed, 95\% CI) & $0.14[0.04,0.48]$ \\
\hline
\end{tabular}

Immunomodulators and immunosuppressants for multiple sclerosis: a network meta-analysis (Review)

Copyright @ 2013 The Cochrane Collaboration. Published by John Wiley \& Sons, Ltd. 
2.7 Azathioprine versus placebo

2.8 Immunoglobulins versus placebo

2.9 Corticosteroids versus placebo

2.10 IFNß-1a (Avonex) versus IFNß-1b (Betaseron)

2.11 IFNß-1a (Rebif) versus IFNß-1a (Avonex)

2.12 Natalizumab versus IFNß-1a (Avonex)

3 Relapse over 12 months in progressive MS

3.1 Azathioprine versus placebo

3.2 Immunoglobulins versus placebo

3.3 Corticosteroids versus Mitoxantrone

(1)

\section{1}

3

1

36

1

188

$1 \quad 677$

1

3

1171

1

1

1
Odds Ratio (M-H, Fixed, 95\% CI)

Odds Ratio (M-H, Fixed, 95\% CI)

Odds Ratio (M-H, Fixed, 95\% CI)

Odds Ratio (M-H, Fixed, 95\% CI)

Odds Ratio (M-H, Fixed, 95\% CI)

Odds Ratio (M-H, Fixed, 95\% CI)

Odds Ratio (M-H, Fixed, 95\% CI)

Odds Ratio (M-H, Fixed, 95\% CI)

Odds Ratio (M-H, Fixed, 95\% CI)

Odds Ratio (M-H, Fixed, 95\% CI)
$0.77[0.25,2.38]$

$0.67[0.38,1.21]$

$0.46[0.12,1.84]$

$1.53[0.86,2.72]$

$0.79[0.58,1.07]$

$0.40[0.32,0.51]$

$1.04[0.70,1.54]$

$0.43[0.16,1.12]$

$1.06[0.66,1.68]$

$4.0[1.11,14.43]$

\section{Comparison 2. Comparisons for relapse over 24 months}

\begin{tabular}{|c|c|c|c|c|}
\hline Outcome or subgroup title & $\begin{array}{l}\text { No. of } \\
\text { studies }\end{array}$ & $\begin{array}{c}\text { No. of } \\
\text { participants }\end{array}$ & Statistical method & Effect size \\
\hline $\begin{array}{l}1 \text { Relapse over } 24 \text { months in MS } \\
\text { of all types }\end{array}$ & 25 & & Odds Ratio (IV, Random, 95\% CI) & Subtotals only \\
\hline $\begin{array}{l}1.1 \mathrm{IFN} ß-1 \mathrm{~b} \text { (Betaseron) } \\
\text { versus placebo }\end{array}$ & 1 & 372 & Odds Ratio (IV, Random, 95\% CI) & $0.55[0.31,0.99]$ \\
\hline $\begin{array}{l}\text { 1.2 IFNß-1a (Avonex) versus } \\
\text { placebo }\end{array}$ & 2 & 737 & Odds Ratio (IV, Random, 95\% CI) & $0.76[0.56,1.05]$ \\
\hline $\begin{array}{l}1.3 \text { IFNß-1a (Rebif) versus } \\
\text { placebo }\end{array}$ & 1 & 560 & Odds Ratio (IV, Random, 95\% CI) & $0.45[0.28,0.71]$ \\
\hline $\begin{array}{l}1.4 \text { Glatiramer acetate versus } \\
\text { placebo }\end{array}$ & 2 & 301 & Odds Ratio (IV, Random, 95\% CI) & $0.49[0.18,1.36]$ \\
\hline $\begin{array}{l}1.5 \text { Natalizumab versus } \\
\text { placebo }\end{array}$ & 1 & 942 & Odds Ratio (IV, Random, 95\% CI) & $0.32[0.24,0.43]$ \\
\hline $\begin{array}{l}\text { 1.6 Mitoxantrone versus } \\
\text { placebo }\end{array}$ & 2 & 245 & Odds Ratio (IV, Random, 95\% CI) & $0.35[0.09,1.42]$ \\
\hline $\begin{array}{l}1.7 \text { Azathioprine versus } \\
\text { placebo }\end{array}$ & 5 & 737 & Odds Ratio (IV, Random, 95\% CI) & $0.64[0.44,0.94]$ \\
\hline $\begin{array}{l}1.8 \text { Immunoglobulins versus } \\
\text { placebo }\end{array}$ & 4 & 705 & Odds Ratio (IV, Random, 95\% CI) & $0.70[0.40,1.22]$ \\
\hline $\begin{array}{l}\text { 1.9 Corticosteroids versus } \\
\text { placebo }\end{array}$ & 1 & 36 & Odds Ratio (IV, Random, 95\% CI) & $1.13[0.06,19.50]$ \\
\hline $\begin{array}{l}\text { 1.10 Methotrexate versus } \\
\text { placebo }\end{array}$ & 1 & 60 & Odds Ratio (IV, Random, 95\% CI) & $1.15[0.31,4.28]$ \\
\hline
\end{tabular}




\begin{tabular}{|c|c|c|c|c|}
\hline $\begin{array}{l}\text { 1.11 IFNß-1a (Avonex) versus } \\
\text { IFNß-1b (Betaseron) }\end{array}$ & 2 & 248 & Odds Ratio (IV, Random, 95\% CI) & $2.26[1.33,3.83]$ \\
\hline $\begin{array}{l}1.12 \text { IFNß-1a (Rebif) versus } \\
\text { IFNß-1a (Avonex) }\end{array}$ & 1 & 60 & Odds Ratio (IV, Random, 95\% CI) & $0.19[0.06,0.60]$ \\
\hline $\begin{array}{l}\text { IFNß-1a (Avonex) } \\
1.13 \text { Natalizumab versus }\end{array}$ & 1 & 1171 & Odds Ratio (IV, Random, 95\% CI) & $0.28[0.22,0.36]$ \\
\hline IFNß-1a (Avonex) & & & & \\
\hline $\begin{array}{l}1.14 \text { IFNß-1a (Rebif) versus } \\
\text { Interferon beta } 1 \mathrm{~b}\end{array}$ & 1 & 60 & Odds Ratio (IV, Random, 95\% CI) & $0.58[0.21,1.62]$ \\
\hline $\begin{array}{l}1.15 \text { Glatiramer acetate versus } \\
\text { IFNß-1b (Betaseron) }\end{array}$ & 1 & 2244 & Odds Ratio (IV, Random, 95\% CI) & $1.05[0.85,1.29]$ \\
\hline $\begin{array}{l}\text { 1.16 Glatiramer acetate versus } \\
\text { IFNß-1a (Rebif) }\end{array}$ & 1 & 764 & Odds Ratio (IV, Random, 95\% CI) & $0.93[0.69,1.25]$ \\
\hline $\begin{array}{l}\text { Relapse over } 24 \text { months in } \\
\text { relapsing-remitting MS }\end{array}$ & 16 & & Odds Ratio (IV, Random, 95\% CI) & Subtotals only \\
\hline $\begin{array}{l}2.1 \mathrm{IFN} ß-1 \mathrm{~b} \text { (Betaseron) } \\
\text { versus placebo }\end{array}$ & 1 & 372 & Odds Ratio (IV, Random, 95\% CI) & $0.55[0.31,0.99]$ \\
\hline $\begin{array}{l}2.2 \text { IFNß-1a (Avonex) versus } \\
\text { placebo }\end{array}$ & 1 & 301 & Odds Ratio (IV, Random, 95\% CI) & $0.83[0.46,1.49]$ \\
\hline $\begin{array}{l}2.3 \text { IFNß-1a (Rebif) versus } \\
\text { placebo }\end{array}$ & 1 & 560 & Odds Ratio (IV, Random, 95\% CI) & $0.45[0.28,0.71]$ \\
\hline $\begin{array}{l}2.4 \text { Glatiramer acetate versus } \\
\text { placebo }\end{array}$ & 2 & 301 & Odds Ratio (IV, Random, 95\% CI) & $0.49[0.18,1.36]$ \\
\hline $\begin{array}{l}2.5 \text { Natalizumab versus } \\
\text { placebo }\end{array}$ & 1 & 942 & Odds Ratio (IV, Random, 95\% CI) & $0.32[0.24,0.43]$ \\
\hline $\begin{array}{l}\text { 2.6 Mitoxantrone versus } \\
\text { placebo }\end{array}$ & 1 & 51 & Odds Ratio (IV, Random, 95\% CI) & $0.15[0.04,0.54]$ \\
\hline $\begin{array}{l}2.7 \text { Azathioprine versus } \\
\text { placebo }\end{array}$ & 1 & 59 & Odds Ratio (IV, Random, 95\% CI) & $0.36[0.11,1.21]$ \\
\hline $\begin{array}{l}2.8 \text { Immunoglobulins versus } \\
\text { placebo }\end{array}$ & 2 & 190 & Odds Ratio (IV, Random, 95\% CI) & $0.22[0.03,1.90]$ \\
\hline $\begin{array}{l}2.9 \text { Corticosteroids versus } \\
\text { placebo }\end{array}$ & 1 & 36 & Odds Ratio (IV, Random, 95\% CI) & $1.13[0.06,19.50]$ \\
\hline $\begin{array}{l}2.10 \text { IFNß-1a (Avonex) versus } \\
\text { IFNß-1b (Betaseron) }\end{array}$ & 2 & 248 & Odds Ratio (IV, Random, 95\% CI) & $2.26[1.33,3.83]$ \\
\hline $\begin{array}{l}2.11 \text { IFNß-1a (Rebif) versus } \\
\text { IFNß-1a (Avonex) }\end{array}$ & 1 & 60 & Odds Ratio (IV, Random, 95\% CI) & $0.19[0.06,0.60]$ \\
\hline $\begin{array}{l}2.12 \text { Natalizumab versus } \\
\text { IFNß-1a (Avonex) }\end{array}$ & 1 & 1171 & Odds Ratio (IV, Random, 95\% CI) & $0.28[0.22,0.36]$ \\
\hline $\begin{array}{l}2.13 \text { IFNß-1a (Rebif) versus } \\
\text { IFNß-1b (Betaseron) }\end{array}$ & 1 & 60 & Odds Ratio (IV, Random, 95\% CI) & $0.58[0.21,1.62]$ \\
\hline $\begin{array}{l}2.14 \text { Glatiramer acetate versus } \\
\text { IFNß-1b (Betaseron) }\end{array}$ & 1 & 2244 & Odds Ratio (IV, Random, 95\% CI) & $1.05[0.85,1.29]$ \\
\hline $\begin{array}{l}2.15 \text { Glatiramer acetate versus } \\
\text { IFNß-1a (Rebif) }\end{array}$ & 1 & 764 & Odds Ratio (IV, Random, 95\% CI) & $0.93[0.69,1.25]$ \\
\hline $\begin{array}{l}\text { Relapse over } 24 \text { months in } \\
\text { progressive MS }\end{array}$ & 6 & & Odds Ratio (IV, Random, 95\% CI) & Subtotals only \\
\hline $\begin{array}{l}3.1 \text { IFNß-1a (Avonex) versus } \\
\text { placebo }\end{array}$ & 1 & 436 & Odds Ratio (IV, Random, 95\% CI) & $0.74[0.51,1.08]$ \\
\hline $\begin{array}{l}\text { 3.2 Mitoxantrone versus } \\
\text { placebo }\end{array}$ & 1 & 194 & Odds Ratio (IV, Random, 95\% CI) & $0.65[0.35,1.20]$ \\
\hline
\end{tabular}


3.3 Azathioprine versus placebo

3.4 Immunoglobulins versus placebo

3.5 Methotrexate versus placebo

$\begin{array}{lcll}1 & 99 & \text { Odds Ratio (IV, Random, 95\% CI) } & 0.56[0.24,1.33] \\ 2 & 515 & \text { Odds Ratio (IV, Random, 95\% CI) } & 0.93[0.66,1.32] \\ 1 & 60 & \text { Odds Ratio (IV, Random, 95\% CI) } & 1.15[0.31,4.28]\end{array}$

Comparison 3. Comparisons for relapse over 36 months

\begin{tabular}{lcclc} 
Outcome or subgroup title & $\begin{array}{c}\text { No. of } \\
\text { studies }\end{array}$ & $\begin{array}{c}\text { No. of } \\
\text { participants }\end{array}$ & Statistical method & Effect size \\
\hline $\begin{array}{l}\text { 1 Relapse over } 36 \text { months in MS } \\
\text { of all types }\end{array}$ & 6 & & Odds Ratio (IV, Random, 95\% CI) & Subtotals only \\
$\quad \begin{array}{l}1.1 \text { IFNß-1b (Betaseron) } \\
\text { versus placebo }\end{array}$ & 2 & 1657 & Odds Ratio (IV, Random, 95\% CI) & $0.71[0.56,0.90]$ \\
$\begin{array}{l}1.2 \text { IFNß-1a (Rebif) versus } \\
\text { placebo }\end{array}$ & 1 & 371 & Odds Ratio (IV, Random, 95\% CI) & $1.28[0.85,1.93]$ \\
$\begin{array}{l}1.3 \text { Azathioprine versus } \\
\text { placebo }\end{array}$ & 3 & 493 & Odds Ratio (IV, Random, 95\% CI) & $0.45[0.27,0.76]$ \\
\hline
\end{tabular}

\section{Comparison 4. Comparisons for disability progression over 24 months}

\begin{tabular}{|c|c|c|c|c|}
\hline Outcome or subgroup title & $\begin{array}{l}\text { No. of } \\
\text { studies }\end{array}$ & $\begin{array}{c}\text { No. of } \\
\text { participants }\end{array}$ & Statistical method & Effect size \\
\hline $\begin{array}{c}1 \text { Disability progression over } 24 \\
\text { months in MS of all types }\end{array}$ & 30 & & Odds Ratio (IV, Random, 95\% CI) & Subtotals only \\
\hline $\begin{array}{l}1.1 \mathrm{IFN} ß-1 \mathrm{~b} \text { (Betaseron) } \\
\text { versus placebo }\end{array}$ & 2 & 445 & Odds Ratio (IV, Random, 95\% CI) & $0.89[0.59,1.36]$ \\
\hline $\begin{array}{l}\text { 1.2 IFNß-1a (Avonex) versus } \\
\text { placebo }\end{array}$ & 3 & 787 & Odds Ratio (IV, Random, 95\% CI) & $0.94[0.71,1.25]$ \\
\hline $\begin{array}{l}1.3 \text { IFNß-1a (Rebif) versus } \\
\text { placebo }\end{array}$ & 2 & 1178 & Odds Ratio (IV, Random, 95\% CI) & $0.71[0.56,0.92]$ \\
\hline $\begin{array}{l}1.4 \text { Glatiramer acetate versus } \\
\text { placebo }\end{array}$ & 4 & 1350 & Odds Ratio (IV, Random, 95\% CI) & $0.76[0.49,1.17]$ \\
\hline $\begin{array}{l}1.5 \text { Natalizumab versus } \\
\text { placebo }\end{array}$ & 1 & 942 & Odds Ratio (IV, Random, 95\% CI) & $0.56[0.42,0.74]$ \\
\hline $\begin{array}{l}\text { 1.6 Mitoxantrone versus } \\
\text { placebo }\end{array}$ & 2 & 245 & Odds Ratio (IV, Random, 95\% CI) & $0.34[0.08,1.44]$ \\
\hline $\begin{array}{l}1.7 \text { Azathioprine versus } \\
\text { placebo }\end{array}$ & 3 & 284 & Odds Ratio (IV, Random, 95\% CI) & $0.77[0.48,1.24]$ \\
\hline $\begin{array}{l}1.8 \text { Immunoglobulins versus } \\
\text { placebo }\end{array}$ & 4 & 739 & Odds Ratio (IV, Random, 95\% CI) & $0.78[0.48,1.25]$ \\
\hline $\begin{array}{l}\text { 1.9 Cyclophosphamide versus } \\
\text { placebo }\end{array}$ & 1 & 44 & Odds Ratio (IV, Random, 95\% CI) & $0.80[0.22,2.94]$ \\
\hline
\end{tabular}


1.10 Corticosteroids versus placebo

1.11 Methotrexate versus placebo

1.12 IFNß-1a (Avonex) versus IFNß-1b (Betaseron)

1.13 IFNß-1a (Rebif) versus

IFNß-1b (Betaseron)

1.14 Natalizumab versus IFNß-1a (Avonex)

1.15 Glatiramer acetate versus IFNß-1b (Betaseron)

1.16 Glatiramer acetate versus IFNß-1a (Rebif)

1.17 Corticosteroids versus

Mitoxantrone

2 Disability progression over 24 months in relapse-remitting MS

2.1 IFNß-1b (Betaseron) versus placebo

2.2 IFNß-1a (Avonex) versus placebo

2.3 IFNß-1a (Rebif) versus placebo

2.4 Glatiramer acetate versus placebo

2.5 Natalizumab versus

placebo

2.6 Mitoxantrone versus

placebo

2.7 Azathioprine versus

placebo

2.8 Immunoglobulins versus placebo

2.9 IFNß-1a (Avonex) versus

IFNß-1b (Betaseron)

2.10 IFNß-1a (Rebif) versus

IFNß-1b (Betaseron)

2.11 Natalizumab versus

IFNß-1a (Avonex)

2.12 Glatiramer acetate versus IFNß-1b (Betaseron)

2.13 Glatiramer acetate versus IFNß-1a (Rebif)

3 Disability progression over 24 months in progressive MS

3.1 IFNß-1b (Betaseron)

versus placebo 3.2 IFNß-1a (Avonex) versus placebo

\section{1}

1
$1.58[0.64,3.87]$

$0.67[0.24,1.87]$

$2.88[1.43,5.79]$

$0.98[0.62,1.54]$

$0.62[0.49,0.78]$

$0.86[0.69,1.06]$

$0.53[0.34,0.83]$

$8.00[0.87,73.68]$

Subtotals only

$0.96[0.61,1.52]$

$0.93[0.59,1.47]$

$0.65[0.45,0.93]$

$0.50[0.14,1.74]$

$0.56[0.42,0.74]$

$0.13[0.03,0.70]$

$0.52[0.17,1.54]$

$0.62[0.30,1.29]$

$2.88[1.43,5.79]$

$0.98[0.62,1.54]$

$0.62[0.49,0.78]$

$0.86[0.69,1.06]$

$0.53[0.34,0.83]$

Subtotals only

$0.62[0.22,1.69]$

$0.95[0.66,1.36]$ 


\begin{tabular}{|c|c|c|c|c|}
\hline $\begin{array}{l}3.3 \text { IFNß-1a (Rebif) versus } \\
\text { placebo }\end{array}$ & 1 & 618 & Odds Ratio (IV, Random, 95\% CI) & $0.78[0.55,1.10]$ \\
\hline $\begin{array}{l}3.4 \text { Glatiramer acetate versus } \\
\text { placebo }\end{array}$ & 2 & 1049 & Odds Ratio (IV, Random, 95\% CI) & $0.94[0.73,1.23]$ \\
\hline $\begin{array}{l}\text { 3.5 Mitoxantrone versus } \\
\text { placebo }\end{array}$ & 1 & 194 & Odds Ratio (IV, Random, 95\% CI) & $0.61[0.27,1.34]$ \\
\hline $\begin{array}{l}3.6 \text { Immunoglobulins versus } \\
\text { placebo }\end{array}$ & 2 & 549 & Odds Ratio (IV, Random, 95\% CI) & $0.83[0.39,1.74]$ \\
\hline $\begin{array}{l}\text { 3.7 Cyclophosphamide versus } \\
\text { placebo }\end{array}$ & 1 & 44 & Odds Ratio (IV, Random, 95\% CI) & $0.80[0.22,2.94]$ \\
\hline $\begin{array}{l}3.8 \text { Corticosteroids versus } \\
\text { placebo }\end{array}$ & 1 & 86 & Odds Ratio (IV, Random, 95\% CI) & $1.58[0.64,3.87]$ \\
\hline $\begin{array}{l}\text { 3.9 Methotrexate versus } \\
\text { placebo }\end{array}$ & 1 & 60 & Odds Ratio (IV, Random, 95\% CI) & $0.67[0.24,1.87]$ \\
\hline $\begin{array}{l}\text { 3.10 Corticosteroids versus } \\
\text { Mitoxantrone }\end{array}$ & 1 & 42 & Odds Ratio (IV, Random, 95\% CI) & $8.00[0.87,73.68]$ \\
\hline
\end{tabular}

\section{Comparison 5. Comparisons for disability progression over 36 months}

\begin{tabular}{lcccc} 
Outcome or subgroup title & $\begin{array}{c}\text { No. of } \\
\text { studies }\end{array}$ & $\begin{array}{c}\text { No. of } \\
\text { participants }\end{array}$ & Statistical method & Effect size \\
\hline $\begin{array}{l}1 \text { Disability progression over 36 } \\
\text { months in progressive MS }\end{array}$ & 7 & & Odds Ratio (IV, Random, 95\% CI) & Subtotals only \\
$\quad \begin{array}{l}1.1 \text { IFNß-1b (Betaseron) } \\
\text { versus placebo }\end{array}$ & 2 & 1657 & Odds Ratio (IV, Random, 95\% CI) & $0.87[0.57,1.33]$ \\
$\quad \begin{array}{l}1.2 \text { IFNß-1a (Rebif) versus } \\
\text { placebo }\end{array}$ & 2 & 989 & Odds Ratio (IV, Random, 95\% CI) & $1.10[0.68,1.80]$ \\
$\quad \begin{array}{l}1.3 \text { Azathioprine versus } \\
\text { placebo }\end{array}$ & 2 & 139 & Odds Ratio (IV, Random, 95\% CI) & $0.47[0.19,1.17]$ \\
$\quad \begin{array}{l}1.4 \text { Cyclophosphamide versus } \\
\text { placebo }\end{array}$ & 1 & 111 & Odds Ratio (IV, Random, 95\% CI) & $1.60[0.76,3.39]$ \\
\hline
\end{tabular}

\section{Comparison 6. Comparison for adverse events}

\begin{tabular}{|c|c|c|c|c|}
\hline Outcome or subgroup title & $\begin{array}{l}\text { No. of } \\
\text { studies }\end{array}$ & $\begin{array}{c}\text { No. of } \\
\text { participants }\end{array}$ & Statistical method & Effect size \\
\hline 1 Serious adverse events & 14 & 5785 & Odds Ratio (M-H, Random, 95\% CI) & $1.14[0.96,1.35]$ \\
\hline 1.1 Interferons versus placebo & 5 & 1866 & Odds Ratio (M-H, Random, 95\% CI) & $1.05[0.80,1.39]$ \\
\hline $\begin{array}{l}1.2 \text { Glatiramer acetate versus } \\
\text { placebo }\end{array}$ & 3 & 1046 & Odds Ratio (M-H, Random, 95\% CI) & $1.71[0.87,3.39]$ \\
\hline $\begin{array}{l}1.3 \text { Natalizumab versus } \\
\text { placebo }\end{array}$ & 2 & 2110 & Odds Ratio (M-H, Random, 95\% CI) & $1.14[0.87,1.50]$ \\
\hline $\begin{array}{l}\text { 1.4 Mitoxantrone versus } \\
\text { placebo }\end{array}$ & 1 & 131 & Odds Ratio (M-H, Random, 95\% CI) & $2.58[0.48,13.81]$ \\
\hline
\end{tabular}

Immunomodulators and immunosuppressants for multiple sclerosis: a network meta-analysis (Review)

Copyright @ 2013 The Cochrane Collaboration. Published by John Wiley \& Sons, Ltd. 
1.5 Intravenous

immunoglobulins versus placebo

2 Withdrawals due to adverse events

2.1 Interferons versus placebo

2.2 Glatiramer acetate versus

2.3 Natalizumab versus

\section{Analysis I.I. Comparison I Comparisons for relapse over I 2 months, Outcome I Relapse over I2 months in MS of all types.}

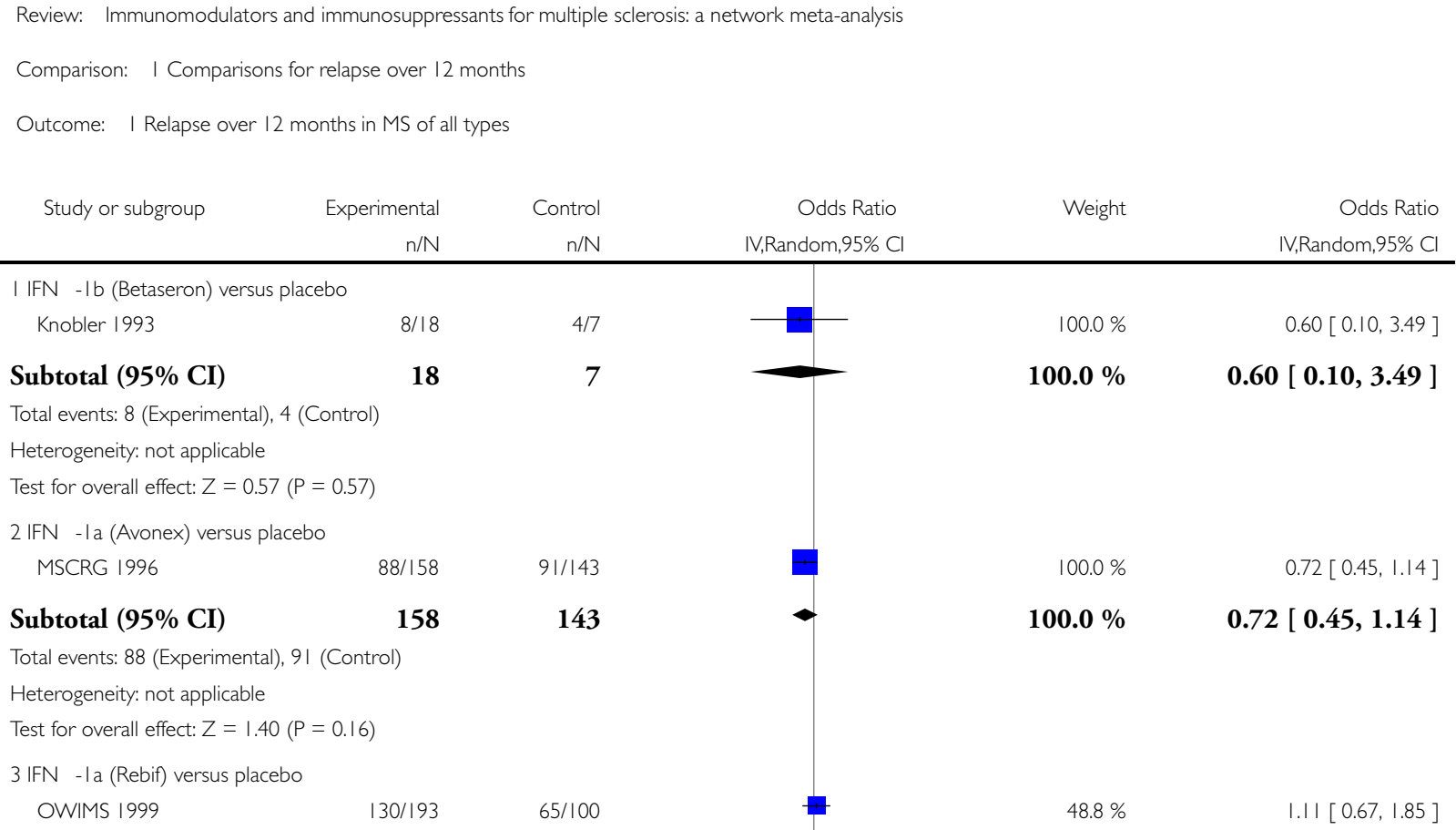

$8 / 18 \quad 4 / 7$

Subtotal $(\mathbf{9 5 \%}$ CI $)$

Total events: 8 (Experimental), 4 (Control)

Heterogeneity: not applicable

Test for overall effect: $Z=0.57(P=0.57)$

2 IFN -la (Avonex) versus placebo MSCRG 1996

$00.0 \%$ $0.60[0.10,3.49]$

Subtotal $(95 \%$ CI)

Total events: 88 (Experimental), 9 I (Control)

Heterogeneity: not applicable

Test for overall effect: $Z=1.40(P=0.16)$

3 IFN -la (Rebif) versus placebo

OWIMS 1999

$65 / 100$

18 )

143

143

$100.0 \%$

$0.72[0.45,1.14]$

$100.0 \% \quad 0.60[0.10,3.49]$

$100.0 \%$

$0.72[0.45,1.14]$ 


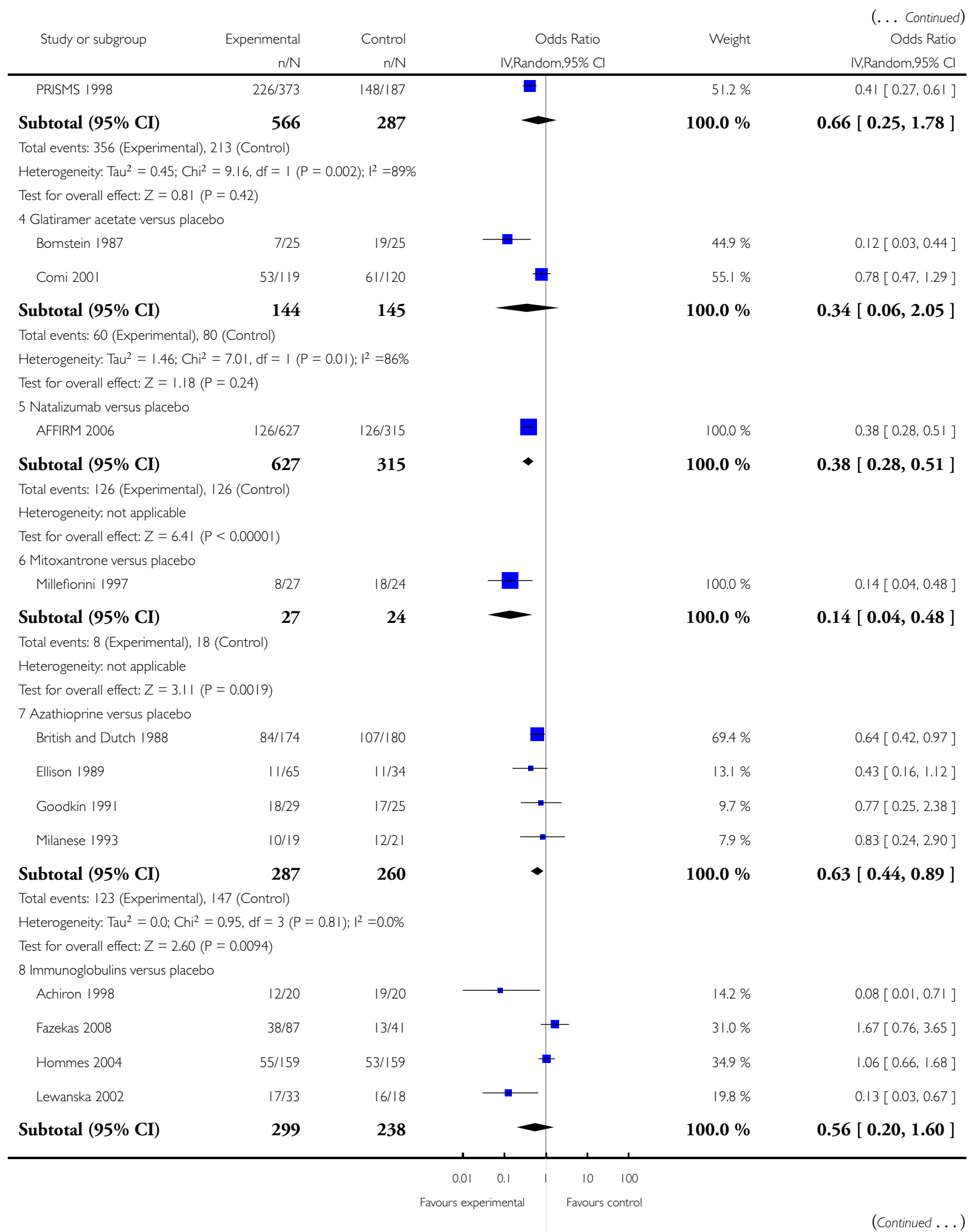

Immunomodulators and immunosuppressants for multiple sclerosis: a network meta-analysis (Review) 
Total events: I 22 (Experimental), I0I (Control)

Heterogeneity: $\mathrm{Tau}^{2}=0.77 ; \mathrm{Chi}^{2}=12.76, \mathrm{df}=3(\mathrm{P}=0.0 \mathrm{I}) ; \mathrm{I}^{2}=76 \%$

Test for overall effect: $Z=1.08(P=0.28)$

9 Corticosteroids versus placebo

BPSM $1995 \quad 10 / 19$

Subtotal (95\% CI)

Total events: 10 (Experimental), 12 (Control)

Heterogeneity: not applicable

Test for overall effect: $Z=1.10(P=0.27)$

I0 IFN - Ia (Avonex) versus IFN - Ib (Betaseron) INCOMIN 2002

48/92

$40 / 96$

92

Subtotal (95\% CI)

Total events: 48 (Experimental), 40 (Control)

Heterogeneity: not applicable

Test for overall effect: $Z=1.44(P=0.15)$

I I IFN - la (Rebif) versus IFN - Ia (Avonex)

EVIDENCE 2007

188/339

$207 / 338$

339

Subtotal (95\% CI)

Total events: 188 (Experimental), 207 (Control)

Heterogeneity: not applicable

Test for overall effect: $Z=1.53(P=0.13)$

12 Natalizumab versus IFN - Ia (Avonex) SENTINEL 2006

$165 / 589$

589

Subtotal (95\% CI)

Total events: 165 (Experimental), 286 (Control)

Heterogeneity: not applicable

Test for overall effect: $Z=7.35(P<0.0000$ I $)$

13 Corticosteroids versus Mitoxantrone

Edan 1997

$14 / 2|\quad 7 / 2|$

Subtotal $(95 \% \mathrm{CI})$

21

Total events: 14 (Experimental), 7 (Control)

Heterogeneity: not applicable

Test for overall effect: $Z=2.12(P=0.034)$

Test for subgroup differences: $\mathrm{Chi}^{2}=46.02, \mathrm{df}=12(\mathrm{P}=0.00), \mathrm{I}^{2}=74 \%$

338

582

21
$100.0 \%$

$0.46[0.12,1.84]$

$100.0 \%$

$0.46[0.12,1.84]$

$100.0 \%$

$1.53[0.86,2.72]$

$100.0 \%$

$1.53[0.86,2.72]$

$100.0 \%$

$0.79[0.58,1.07]$

$\checkmark$

$100.0 \%$

0.79 [ $0.58,1.07$ ]

$100.0 \%$

$0.40[0.32,0.51]$

$100.0 \%$

$0.40[0.32,0.51$ ]

$\bullet$

政

$100.0 \%$

$4.00[1.11,14.43]$

$100.0 \%$

$4.00[1.11,14.43]$ 


\section{Analysis I.2. Comparison I Comparisons for relapse over 12 months, Outcome 2 Relapse over 12 months} in relapsing-remitting $\mathrm{MS}$.

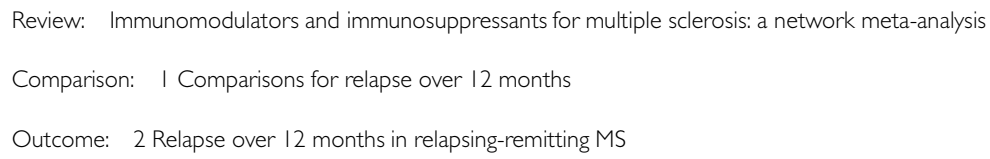

$\mathrm{n} / \mathrm{N} \quad \mathrm{n} / \mathrm{N}$
M-H,Fixed,95\% Cl

Weight

Odds Ratio

I IFN - Ib (Betaseron) versus placebo

Knobler 1993

$8 / 18$

$4 / 7$

18

7 $\mathrm{M}-\mathrm{H}$, Fixed,95\% Cl

Subtotal (95\% CI)

Total events: 8 (Experimental), 4 (Control)

Heterogeneity: not applicable

Test for overall effect: $Z=0.57(P=0.57)$

2 IFN - Ia (Avonex) versus placebo

MSCRG 1996

$88 / 158 \quad 91 / 143$

Subtotal (95\% CI)

143

Total events: 88 (Experimental), 9। (Control)

Heterogeneity: not applicable

Test for overall effect: $Z=1.40(P=0.16)$

3 IFN - Ia (Rebif) versus placebo

OWIMS 1999

$130 / 193 \quad 65 / 100$

PRISMS 1998

$226 / 373$

148/187

Subtotal (95\% CI)

566

287

Total events: 356 (Experimental), 213 (Control)

Heterogeneity: $\mathrm{Chi}^{2}=9.17, \mathrm{df}=|(P=0.002) ;|^{2}=89 \%$

Test for overall effect: $Z=3.28(P=0.0010)$

4 Glatiramer acetate versus placebo

$$
\text { Bornstein } 1987
$$

Comi 200I

$7 / 25$

$53 / 119$

144

Subtotal (95\% CI)

Total events: 60 (Experimental), 80 (Control)

Heterogeneity: $\mathrm{Chi}^{2}=7.02, \mathrm{df}=\mathrm{I}(\mathrm{P}=0.0 \mathrm{I}) ; \mathrm{I}^{2}=86 \%$

Test for overall effect: $Z=2.27(P=0.024)$

5 Natalizumab versus placebo

$$
\text { AFFIRM } 2006
$$

Subtotal (95\% CI)

Total events: 126 (Experimental), I 26 (Control)

Heterogeneity: not applicable

Test for overall effect: $Z=6.4 \mathrm{I}(P<0.0000 \mathrm{I})$

$0.5 \%$

\begin{tabular}{r|r}
. & \\
\hline & \\
\hline
\end{tabular}

$0.5 \%$

$0.60[0.10,3.49]$

$0.60[0.10,3.49]$

$6.0 \%$

$0.72[0.45,1.14]$

$6.0 \%$

$0.72[0.45,1.14]$

$4.0 \%$

I.I I $[0.67,1.85]$

$11.0 \%$

$0.41[0.27,0.61]$

$15.0 \%$

0.59 [ $0.43,0.81$ ]

$1.9 \%$

$4.8 \%$

$0.12[0.03,0.44]$

$0.78[0.47,1.29]$

$6.7 \%$

0.59 [ 0.37, 0.93 ]

$19.0 \%$

$0.38[0.28,0.51]$

$19.0 \%$

$0.38[0.28,0.51]$ 


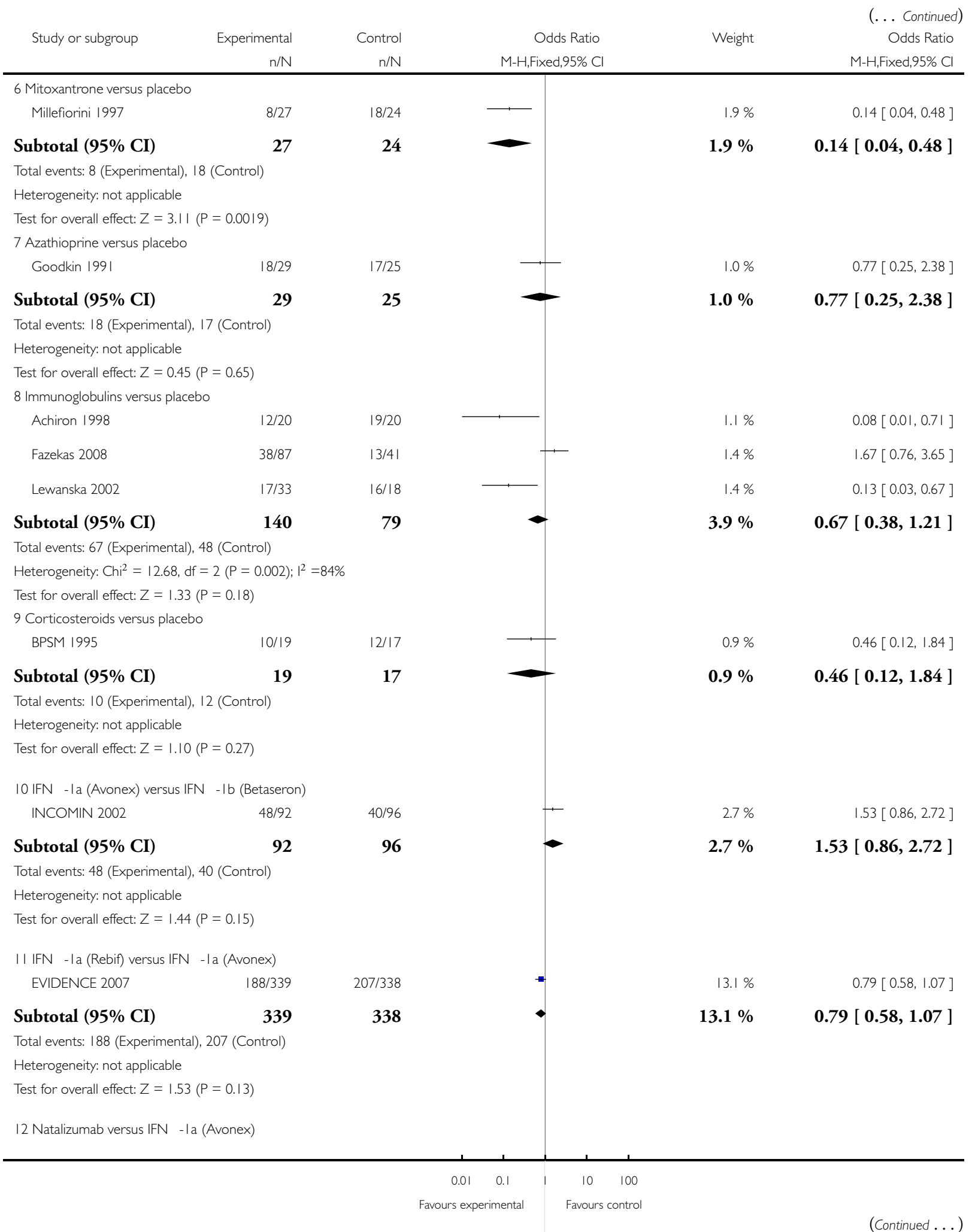




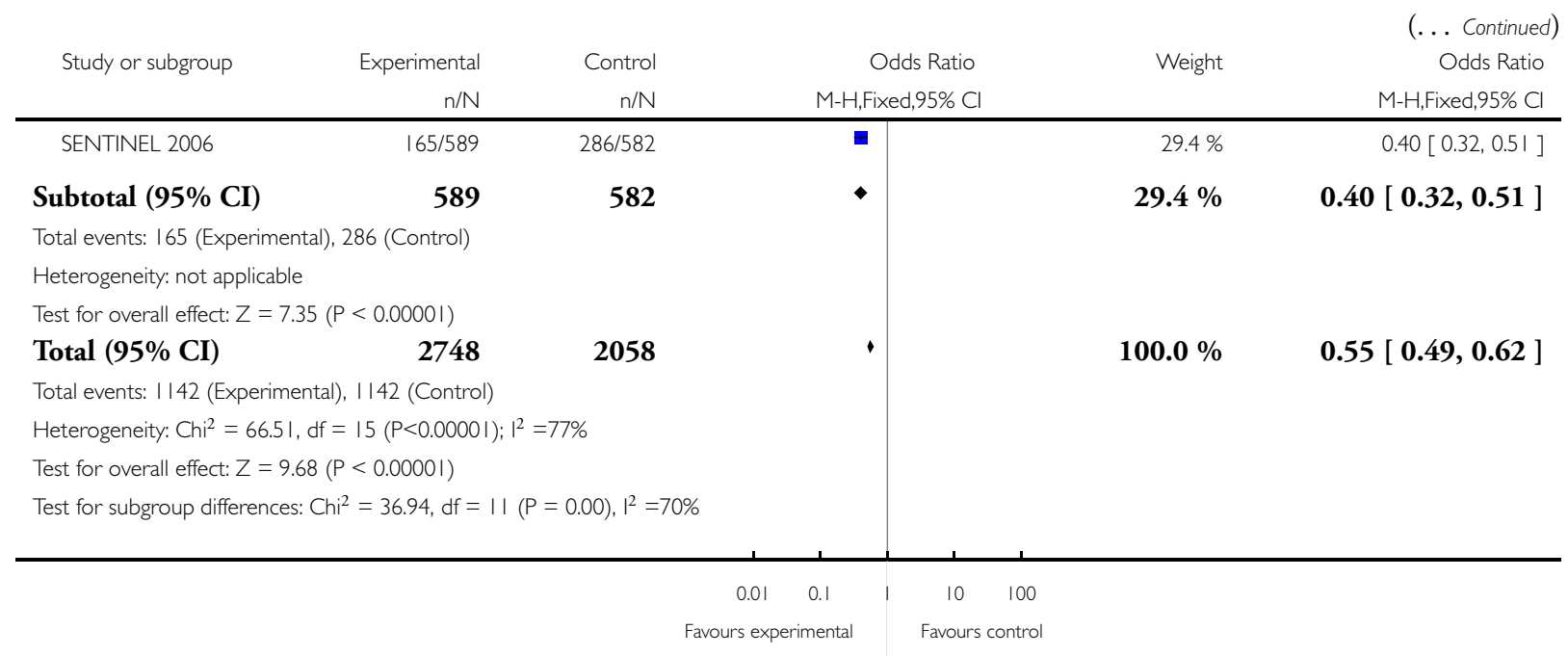

Analysis I.3. Comparison I Comparisons for relapse over 12 months, Outcome 3 Relapse over 12 months in progressive MS.

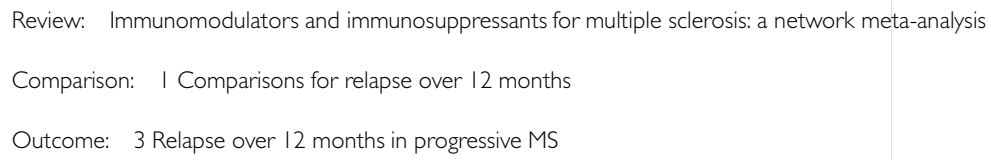

Subtotal (95\% CI)

Total events: I I (Experimental), I I (Control)

Heterogeneity: not applicable

Test for overall effect: $Z=1.73(P=0.084)$

2 Immunoglobulins versus placebo

$$
\text { Hommes } 2004
$$

Total events: 55 (Experimental), 53 (Control)

Heterogeneity: not applicable

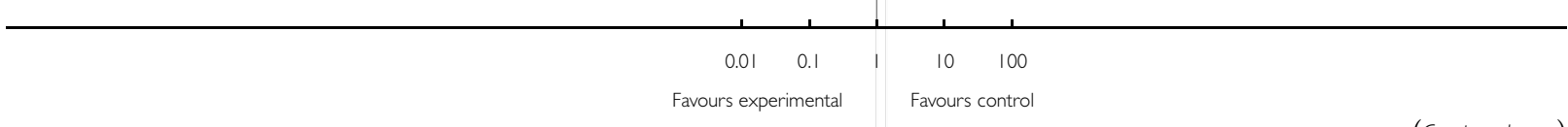




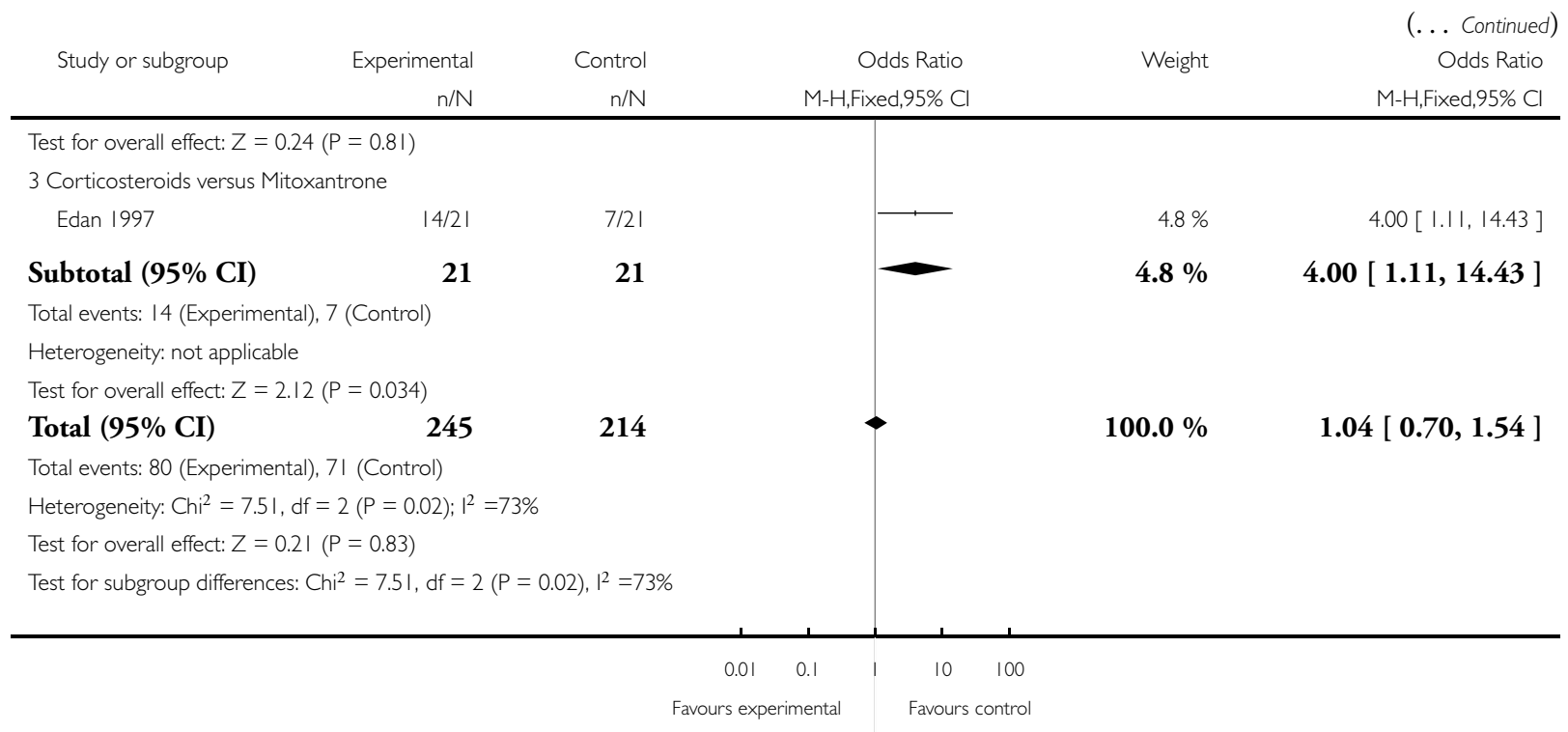


Analysis 2.I. Comparison 2 Comparisons for relapse over 24 months, Outcome I Relapse over 24 months in MS of all types.

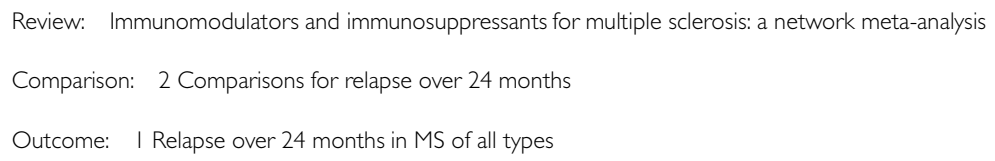

Total events: 94 (Experimental), I I (Control)

Heterogeneity: $\operatorname{Tau}^{2}=0.35 ; \mathrm{Chi}^{2}=2.55, \mathrm{df}=1(\mathrm{P}=0.1 \mathrm{I}) ; \mathrm{I}^{2}=61 \%$

Test for overall effect: $Z=1.37(P=0.17)$

5 Natalizumab versus placebo

$$
\begin{array}{lll}
\text { AFFIRM } 2006 & 225 / 627 & 200 / 315
\end{array}
$$

Subtotal (95\% CI)

r

\section{$+$}

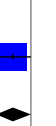

3

(2)

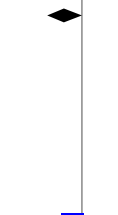

(2)




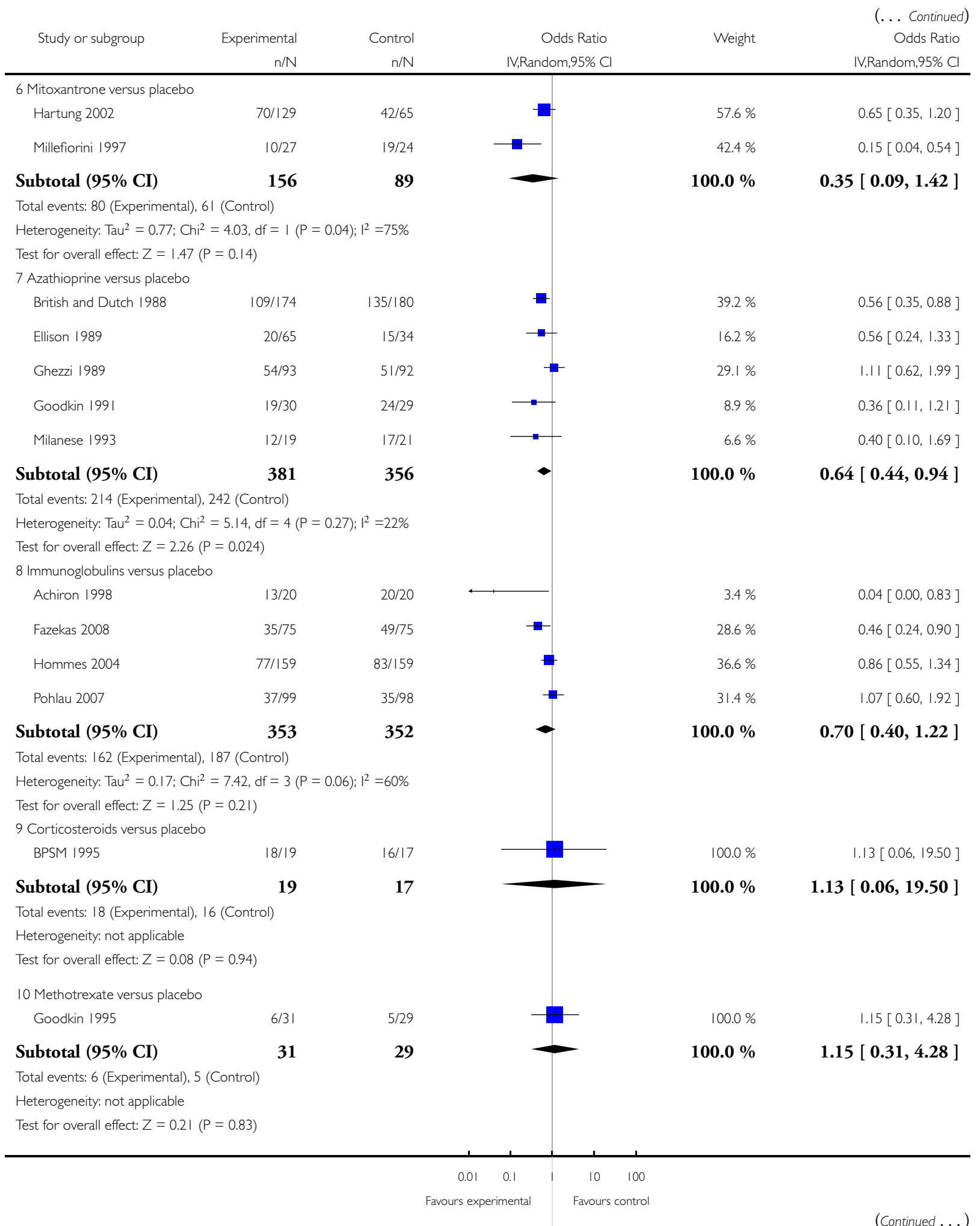




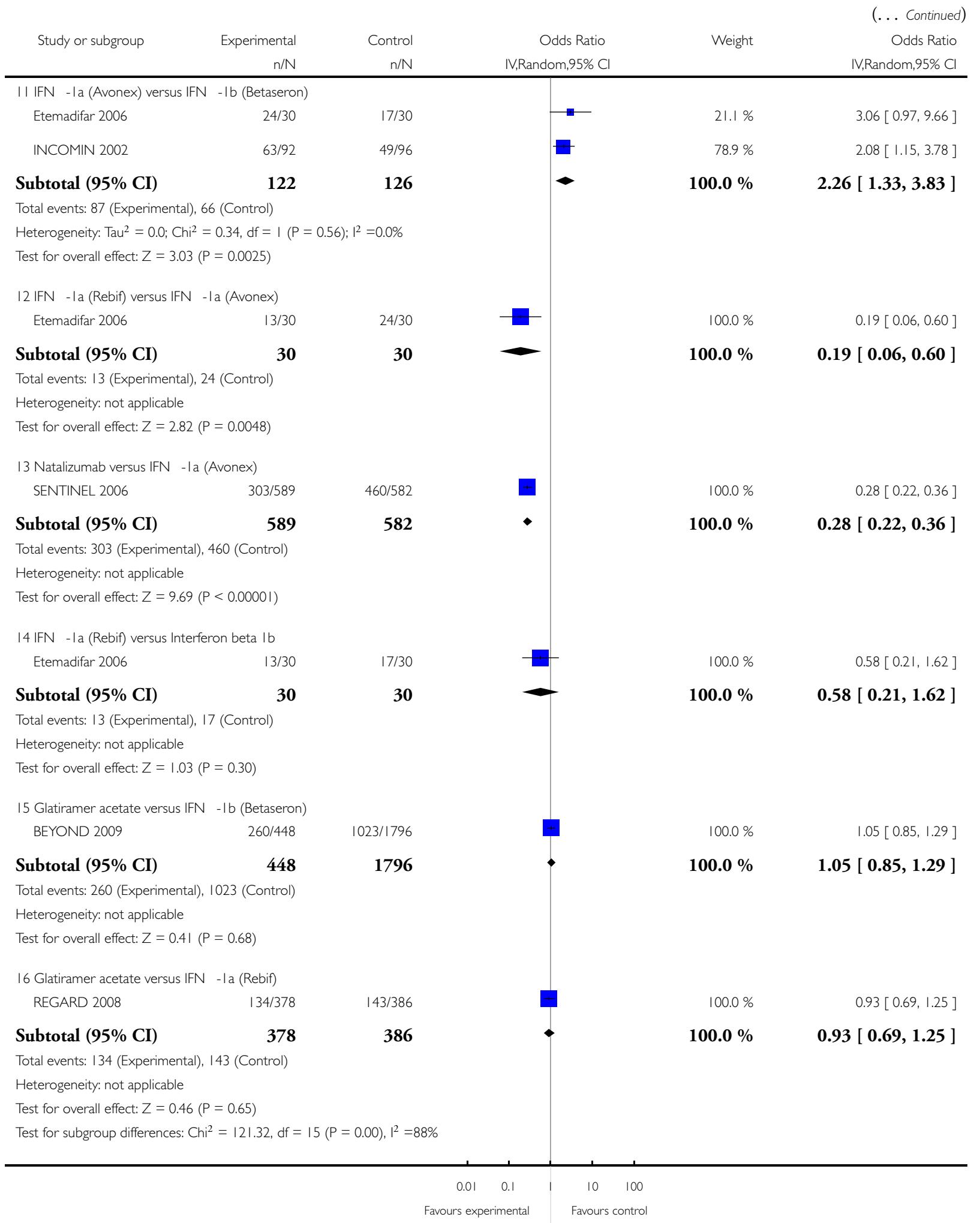


Analysis 2.2. Comparison 2 Comparisons for relapse over 24 months, Outcome 2 Relapse over 24 months in relapsing-remitting $\mathrm{MS}$.

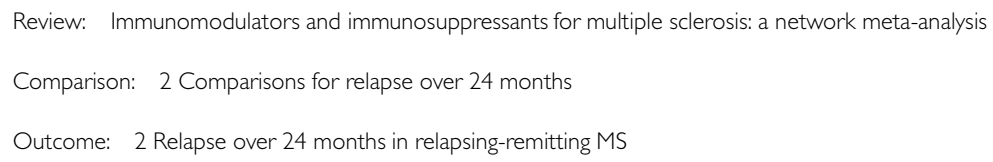
,Random, $95 \% \mathrm{Cl}$ V,Random, $95 \% \mathrm{Cl}$

I IFN - Ib (Betaseron) versus placebo

IFNB MS Group 1993

190/249

$105 / 123$

249

123

Subtotal $(95 \% \mathrm{CI})$

Total events: 190 (Experimental), 105 (Control)

Heterogeneity: not applicable

Test for overall effect: $Z=2.01 \quad(P=0.044)$

2 IFN -la (Avonex) versus placebo

MSCRG 1996

$127 / 158$

119/143

$100.0 \%$

$0.83[0.46,1.49]$

Subtotal (95\% CI)

158

143

Total events: I27 (Experimental), I 9 (Control)

Heterogeneity: not applicable

Test for overall effect: $Z=0.64(P=0.53)$

3 IFN -la (Rebif) versus placebo

PRISMS 1998

$268 / 373$

$159 / 187$

$100.0 \%$

$0.45[0.28,0.71]$

Subtotal (95\% CI)

373

187

Total events: 268 (Experimental), 159 (Control)

Heterogeneity: not applicable

Test for overall effect: $Z=3.40(P=0.00067)$

4 Glatiramer acetate versus placebo

$\begin{array}{lrr}\text { Bornstein } 1987 & 11 / 25 & 19 / 25 \\ \text { Johnson } 1995 & 83 / 125 & 92 / 126\end{array}$

$19 / 25$

$92 / 126$

Subtotal $(95 \%$ CI)

150

151

Total events: 94 (Experimental), I I I (Control)

Heterogeneity: $\operatorname{Tau}^{2}=0.35 ; \mathrm{Chi}^{2}=2.55, \mathrm{df}=\mathrm{I}(\mathrm{P}=0.1 \mathrm{I}) ; \mathrm{I}^{2}=61 \%$

Test for overall effect: $Z=1.37(P=0.17)$

5 Natalizumab versus placebo

\begin{tabular}{l|l|l} 
AFFIRM 2006 & 200 & $100.0 \%$
\end{tabular}

Subtotal $(95 \% \mathrm{CI})$

627

315

$\bullet$

$100.0 \%$
$36.9 \%$

$0.25[0.07,0.83]$

$63.1 \%$

$0.73[0.43,1.25]$

$0.45[0.28,0.71]$

$100.0 \%$

0.49 [ $0.18,1.36$ ] $\begin{array}{ccccc}0.01 & 0.1 & 1 & 10 & 100 \\ \text { Favours experimental } & \text { Favours control }\end{array}$
(Continued....) 


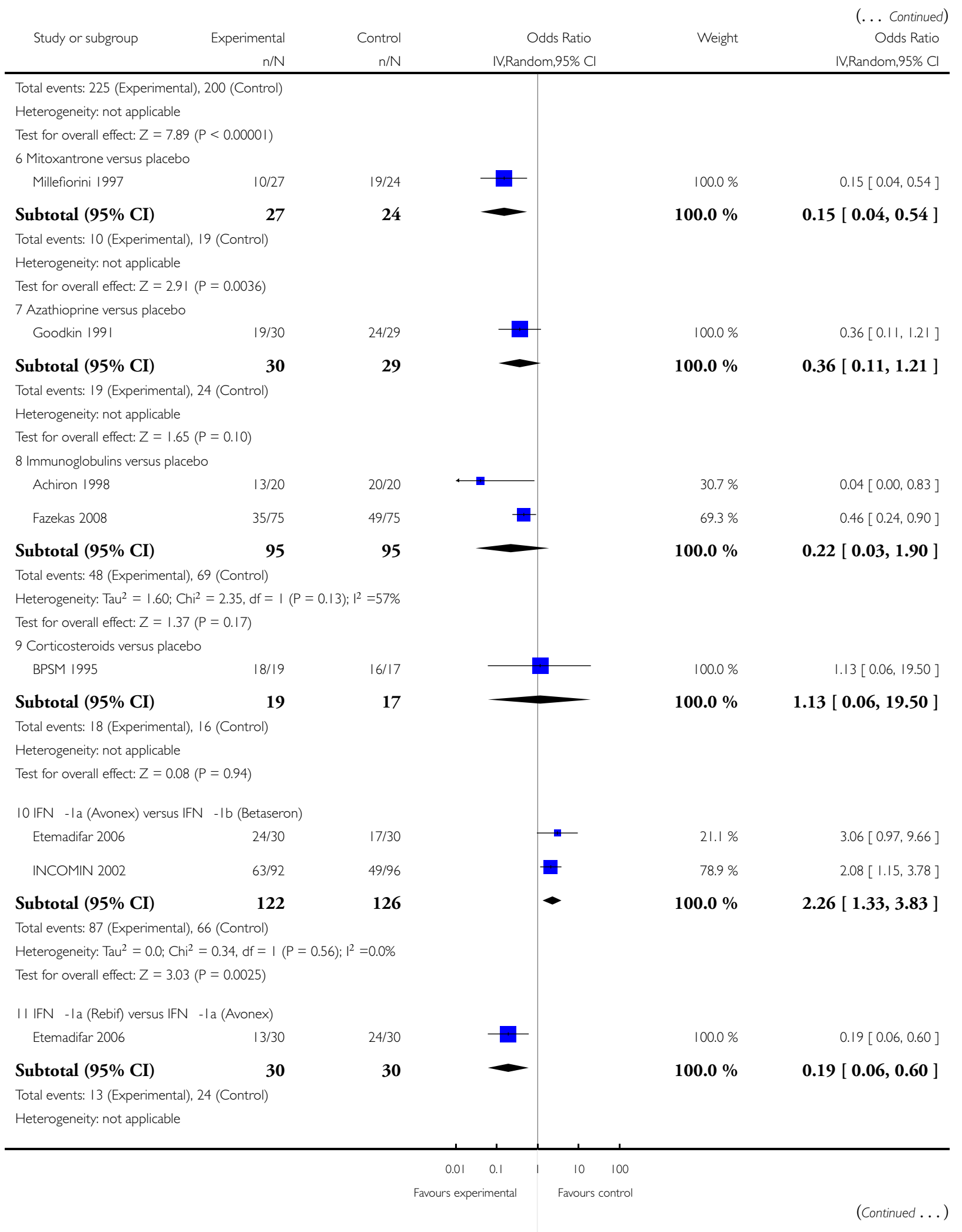




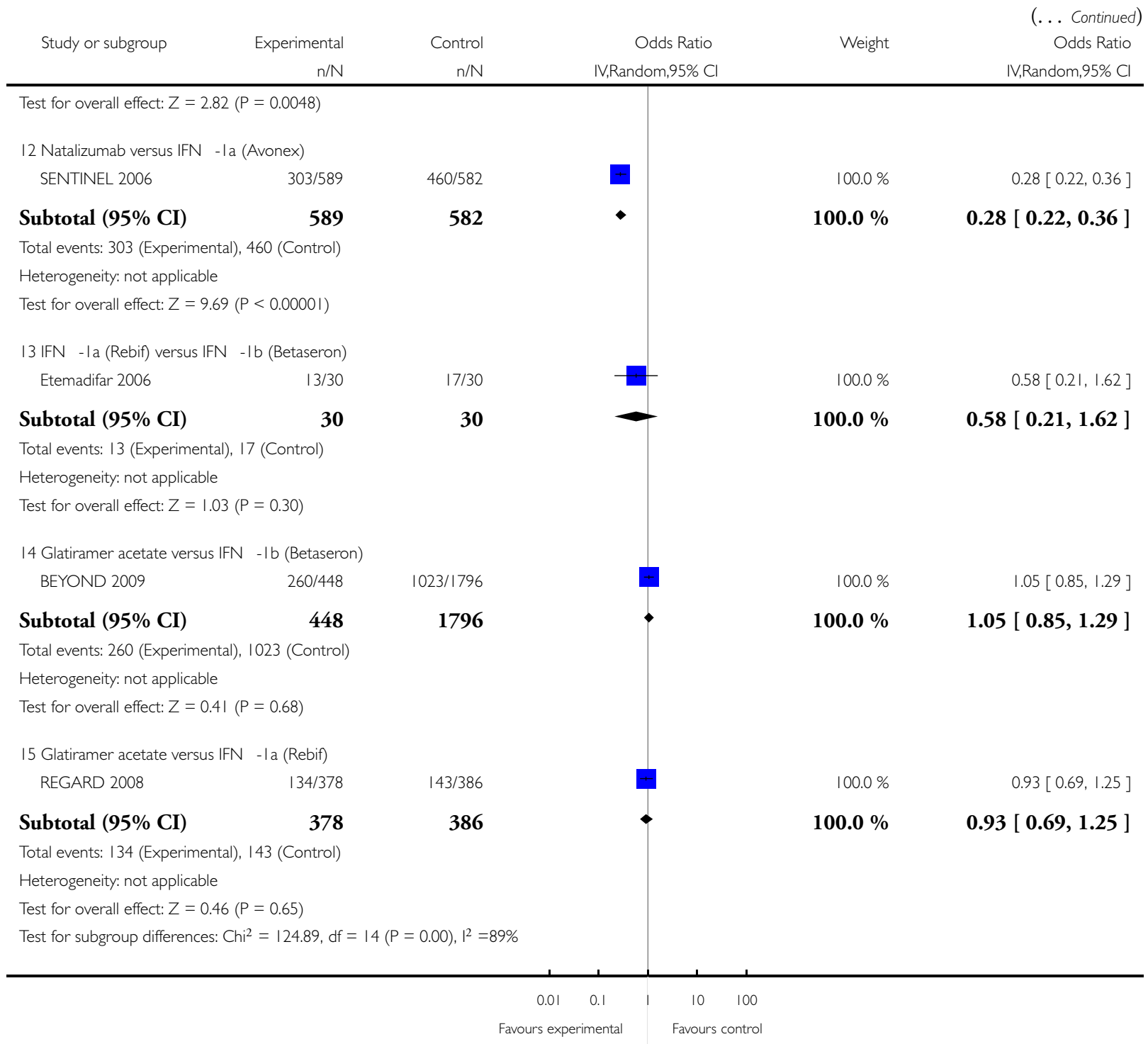


Analysis 2.3. Comparison 2 Comparisons for relapse over 24 months, Outcome 3 Relapse over 24 months in progressive MS.

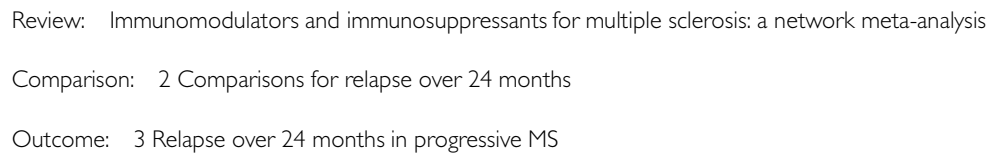

Subtotal (95\% CI)

Heterogeneity: not applicable

Test for overall effect: $Z=1.37(P=0.17)$

3 Azathioprine versus placebo

Ellison 1989

Subtotal (95\% CI)

Heterogeneity: not applicable

Test for overall effect: $Z=1.31(P=0.19)$

4 Immunoglobulins versus placebo

$\begin{array}{lrr}\text { Hommes } 2004 & 77 / 159 & 83 / 159 \\ \text { Pohlau } 2007 & 37 / 99 & 35 / 98\end{array}$

Subtotal $(95 \%$ CI)

\section{7}

Total events: I I 4 (Experimental), I 8 (Control)

Heterogeneity: $\mathrm{Tau}^{2}=0.0 ; \mathrm{Chi}^{2}=0.36, \mathrm{df}=\mathrm{I}(\mathrm{P}=0.55) ; \mathrm{I}^{2}=0.0 \%$

Test for overall effect: $Z=0.39(P=0.70)$

5 Methotrexate versus placebo

$$
\text { Goodkin } 1995 \quad 6 / 31 \quad 5 / 29
$$

Subtotal (95\% CI)

Total events: 6 (Experimental), 5 (Control)

Heterogeneity: not applicable

Test for overall effect: $Z=0.21(P=0.83)$

Test for subgroup differences: $\mathrm{Chi}^{2}=2.28, \mathrm{df}=4(\mathrm{P}=0.68), \mathrm{I}^{2}=0.0 \%$

$100.0 \%$

$63.5 \%$

$36.5 \%$

$100.0 \%$

$100.0 \%$
$0.56[0.24,1.33]$

$0.86[0.55,1.34]$

$1.07[0.60,1.92]$

$0.93[0.66,1.32$ ]

1.15 [ $0.31,4.28$ ] 
Analysis 3.I. Comparison 3 Comparisons for relapse over 36 months, Outcome I Relapse over 36 months in MS of all types.

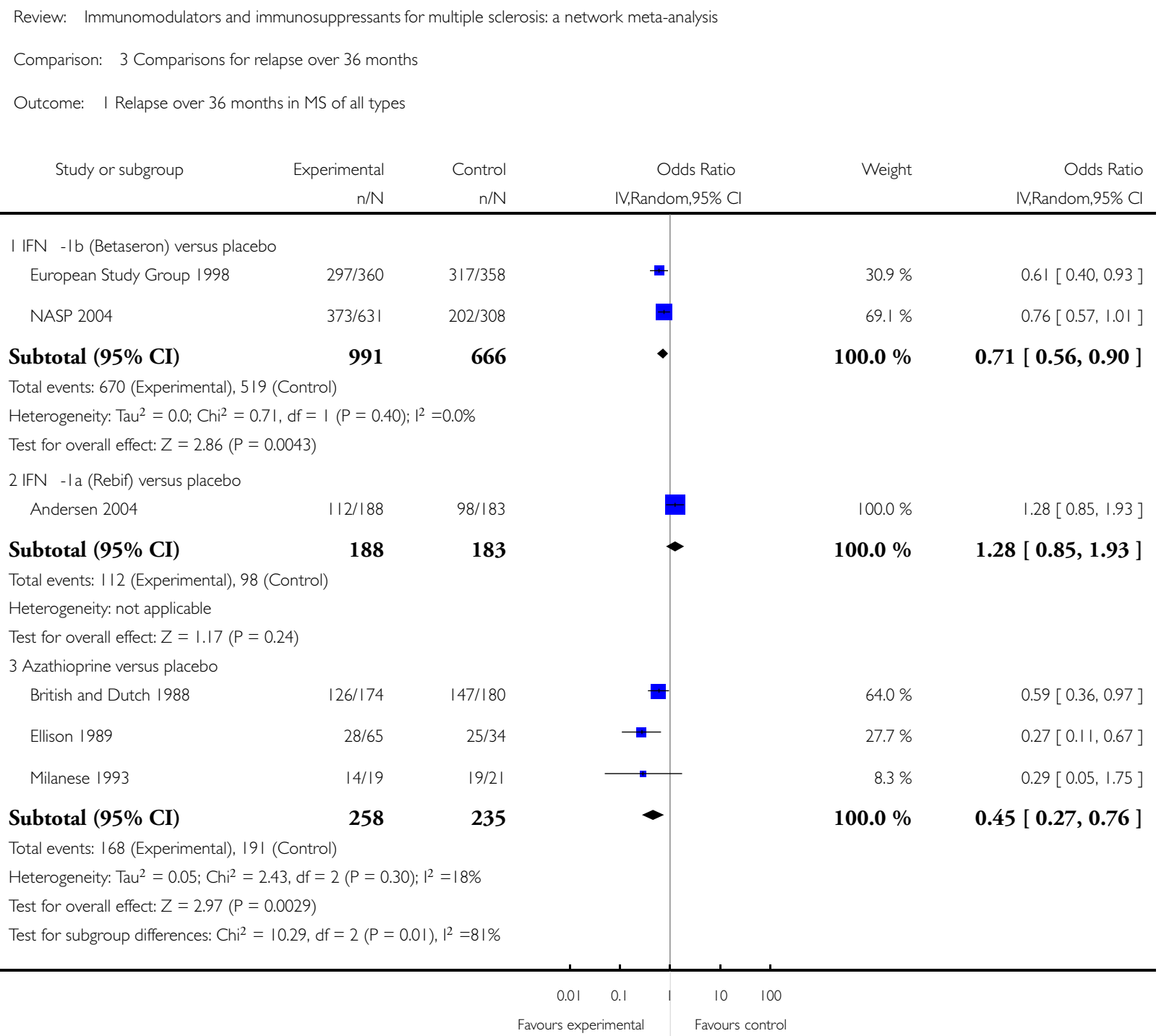


Analysis 4.I. Comparison 4 Comparisons for disability progression over 24 months, Outcome I Disability progression over 24 months in MS of all types.

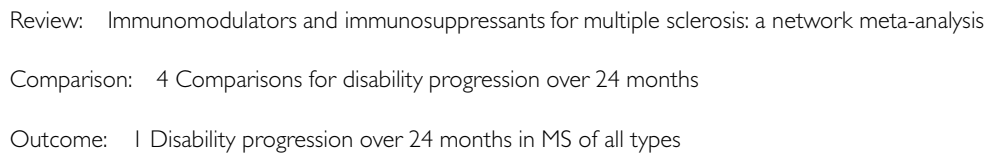
$\mathrm{n} / \mathrm{N} \quad \mathrm{n} / \mathrm{N} \quad \mathrm{IV}, \mathrm{Random}, 95 \% \mathrm{Cl} \quad \mathrm{IV}, \mathrm{Random}, 95 \% \mathrm{Cl}$

$\begin{array}{ll}83.1 \% & 0.96[0.61,1.52] \\ 16.9 \% & 0.62[0.22,1.69]\end{array}$

$100.0 \%$

0.89 [ $0.59,1.36$ ]

$55.0 \%$

$0.90[0.62,1.33]$

$6.3 \%$

$1.40[0.45,4.35]$

$38.7 \%$

$0.93[0.59,1.47]$

$100.0 \%$

$0.94[0.71,1.25]$

$47.3 \%$

$0.65[0.45,0.93]$

$52.7 \%$

$0.78[0.55,1.10]$

$100.0 \%$

0.71 [ 0.56, 0.92 ]

$9.8 \%$

$0.23[0.07,0.81]$

$15.4 \%$

$0.63[0.24,1.61]$

$27.8 \%$

$0.84[0.47,1.52]$

$0.98[0.74,1.28]$

$46.9 \%$

$100.0 \%$ 


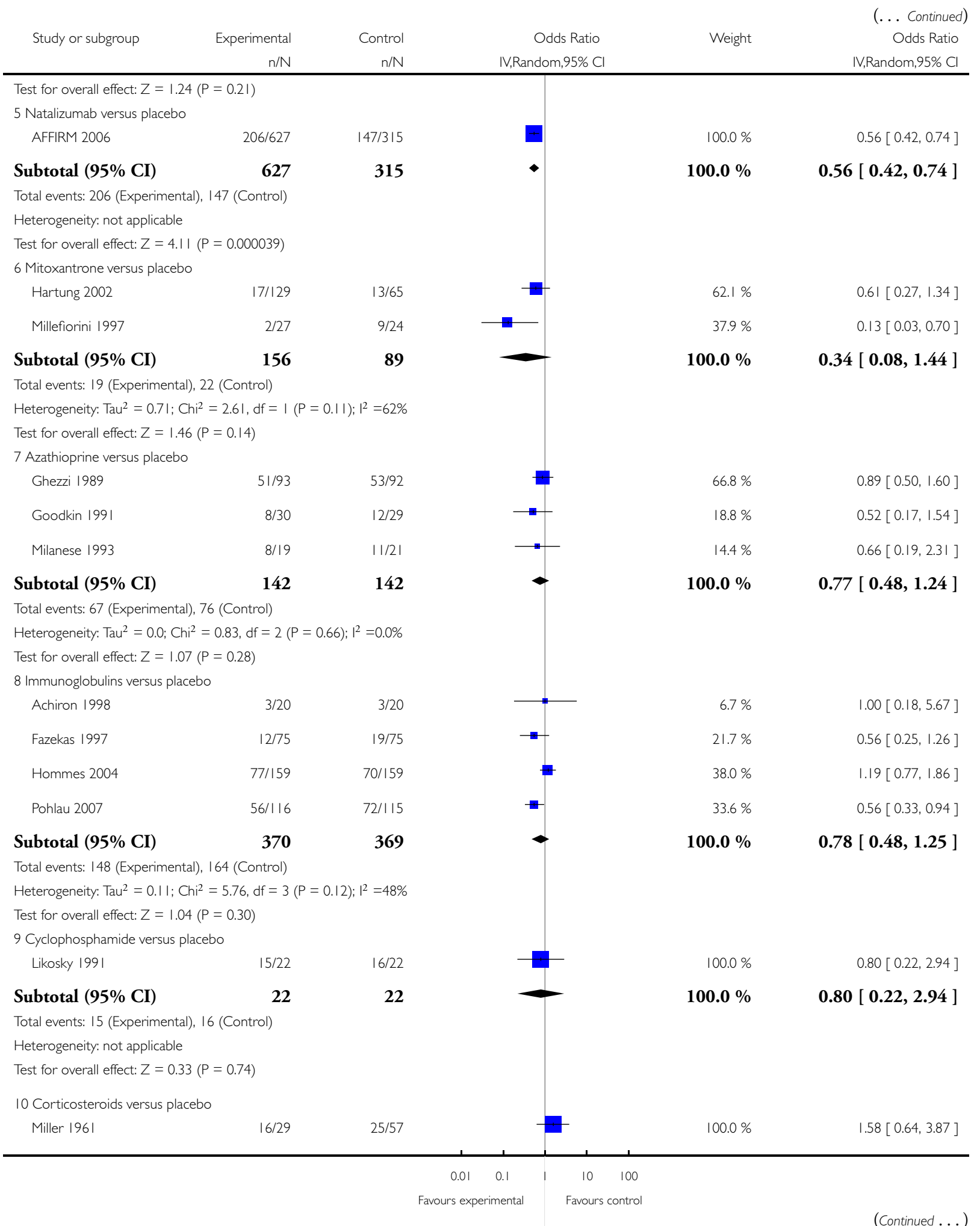




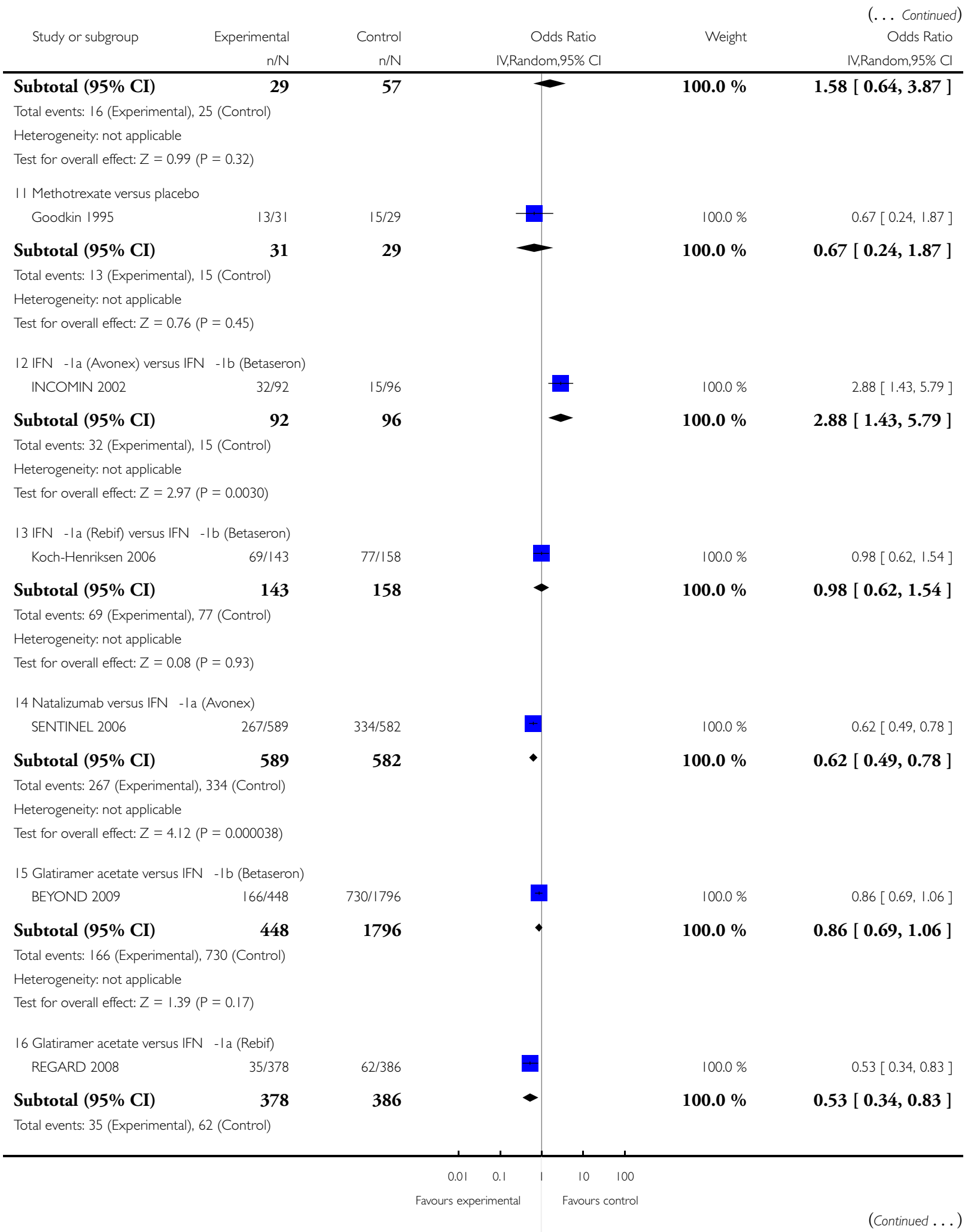




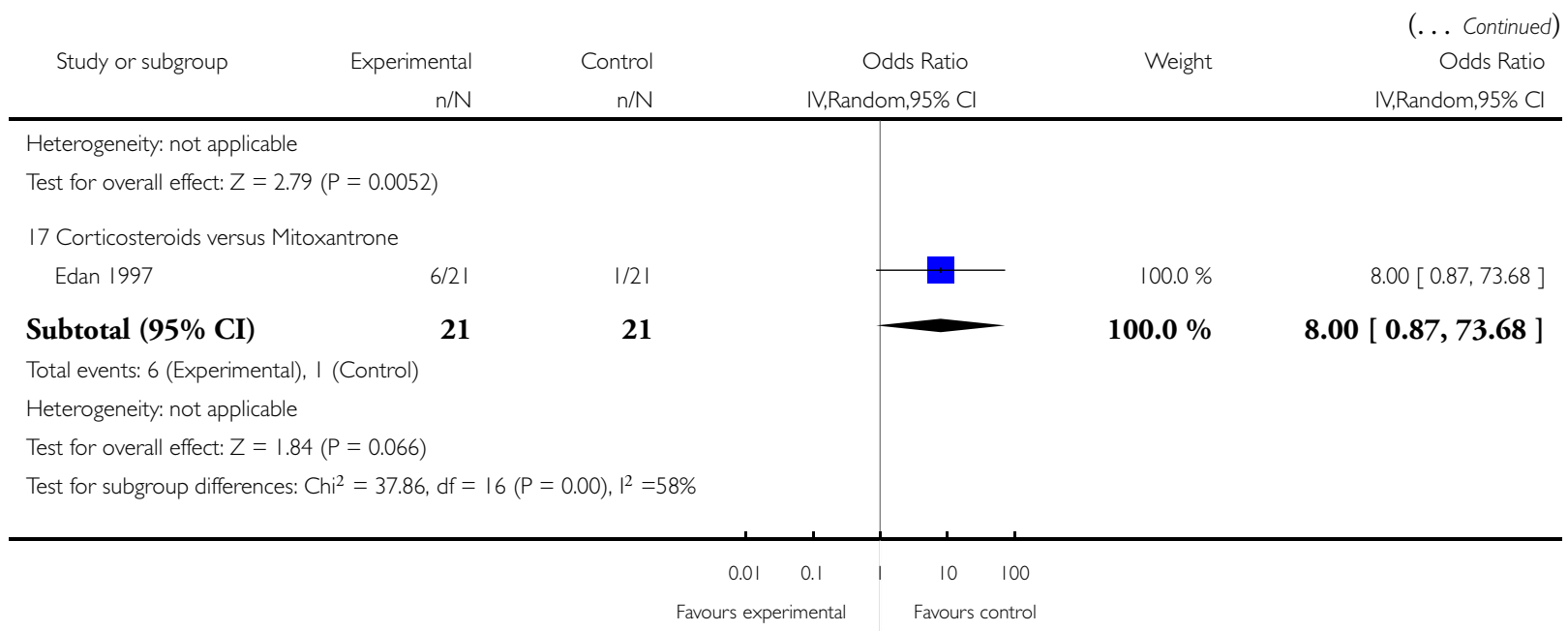

Analysis 4.2. Comparison 4 Comparisons for disability progression over 24 months, Outcome 2 Disability progression over 24 months in relapse-remitting MS.

Review: Immunomodulators and immunosuppressants for multiple sclerosis: a network meta-analysis

Comparison: 4 Comparisons for disability progression over 24 months

Outcome: 2 Disability progression over 24 months in relapse-remitting MS

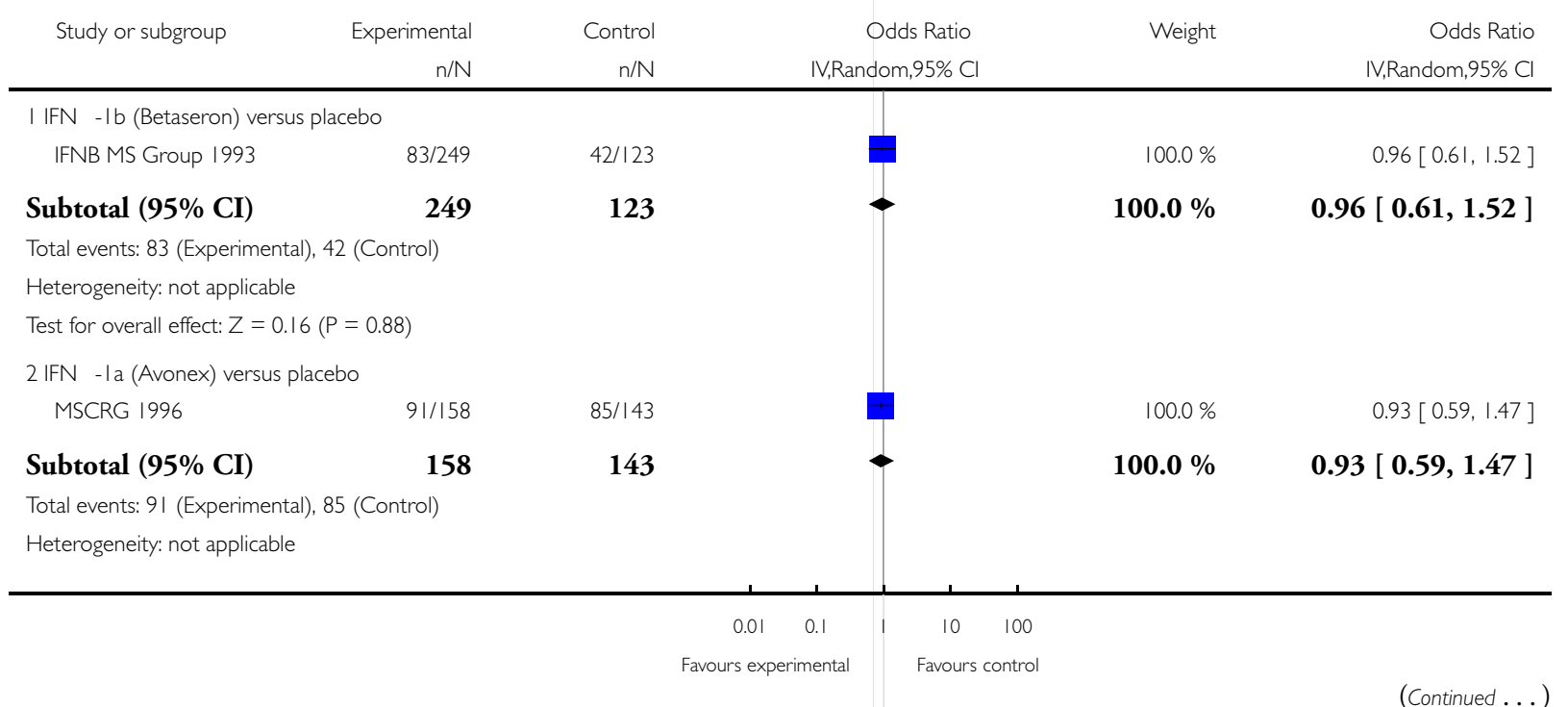

Immunomodulators and immunosuppressants for multiple sclerosis: a network meta-analysis (Review) 
Test for overall effect: $Z=0.32(P=0.75)$

3 IFN - Ia (Rebif) versus placebo PRISMS 1998

(1)

\section{Subtotal (95\% CI)}

Total events: 120 (Experimental), 79 (Control)

\section{Heterogeneity: not applicable}

Test for overall effect: $Z=2.34(P=0.019)$

4 Glatiramer acetate versus placebo

$\begin{array}{lrr}\text { Bornstein } 1987 & 5 / 25 & 13 / 25 \\ \text { Johnson } 1995 & 27 / 125 & 31 / 126\end{array}$

\section{Subtotal (95\% CI)}

Total events: 32 (Experimental), 44 (Control)

Heterogeneity: $\mathrm{Tau}^{2}=0.59 ; \mathrm{Chi}^{2}=3.36, \mathrm{df}=\mathrm{I}(\mathrm{P}=0.07) ; \mathrm{I}^{2}=70 \%$

Test for overall effect: $Z=1.09(P=0.28)$

5 Natalizumab versus placebo

$$
\text { AFFIRM } 2006
$$

Total events: 206 (Experimental), 147 (Control)

Heterogeneity: not applicable

Test for overall effect: $Z=4.1$ I $(P=0.000039)$

6 Mitoxantrone versus placebo

Millefiorini 1997

Subtotal (95\% CI)

Total events: 2 (Experimental), 9 (Control)

Heterogeneity: not applicable

Test for overall effect: $Z=2.38(P=0.017)$

7 Azathioprine versus placebo

Goodkin 1991

Subtotal (95\% CI)

Total events: 8 (Experimental), 12 (Control)

Heterogeneity: not applicable

Test for overall effect: $Z=1.19(P=0.24)$

8 Immunoglobulins versus placebo

$$
\text { Achiron } 1998
$$

95

Subtotal (95\% CI)

Total events: I5 (Experimental), 22 (Control)

Heterogeneity: $\mathrm{Tau}^{2}=0.0 ; \mathrm{Chi}^{2}=0.35, \mathrm{df}=\mathrm{I}(\mathrm{P}=0.55) ; \mathrm{I}^{2}=0.0 \%$

Test for overall effect: $Z=1.27(P=0.20)$

9 IFN - la (Avonex) versus IFN - Ib (Betaseron)

INCOMIN 2002

32/92

$15 / 96$
$100.0 \%$

$40.5 \%$

$59.5 \%$

$100.0 \%$

$100.0 \%$

$100.0 \%$

$100.0 \%$

$0.13[0.03,0.70]$

$100.0 \%$

$100.0 \%$

$0.52[0.17,1.54]$

$0.52[0.17,1.54]$

$17.8 \%$

$1.00[0.18,5.67]$

$82.2 \%$

$0.56[0.25,1.26]$

$100.0 \%$

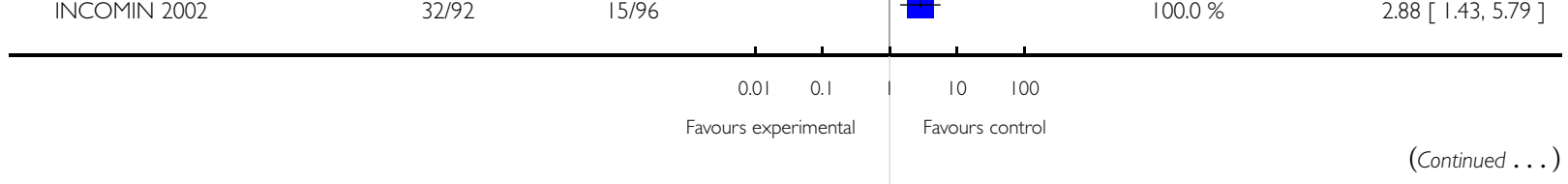

Immunomodulators and immunosuppressants for multiple sclerosis: a network meta-analysis (Review)

Copyright @ 2013 The Cochrane Collaboration. Published by John Wiley \& Sons, Ltd. 


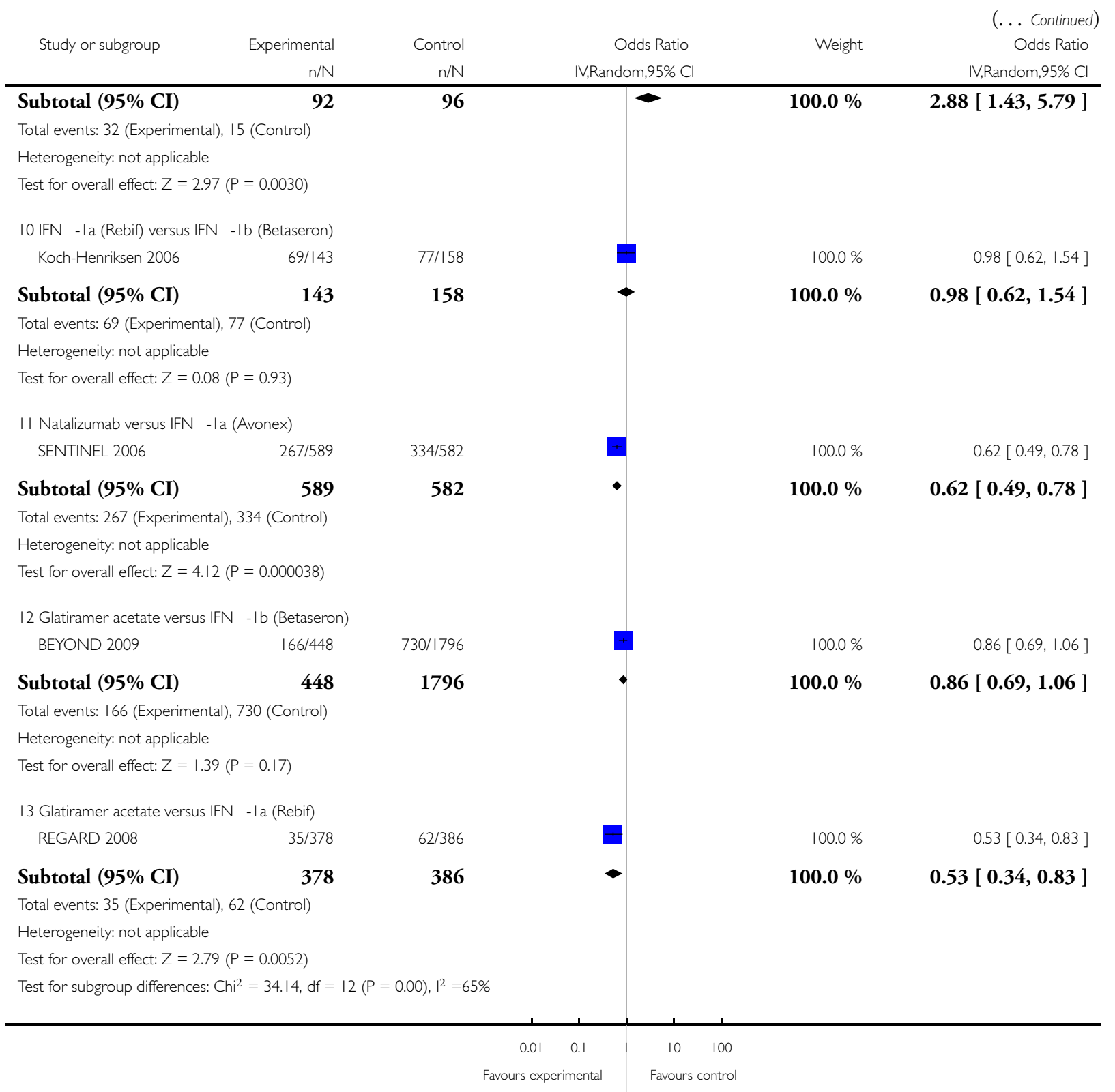


Analysis 4.3. Comparison 4 Comparisons for disability progression over 24 months, Outcome 3 Disability progression over 24 months in progressive MS.

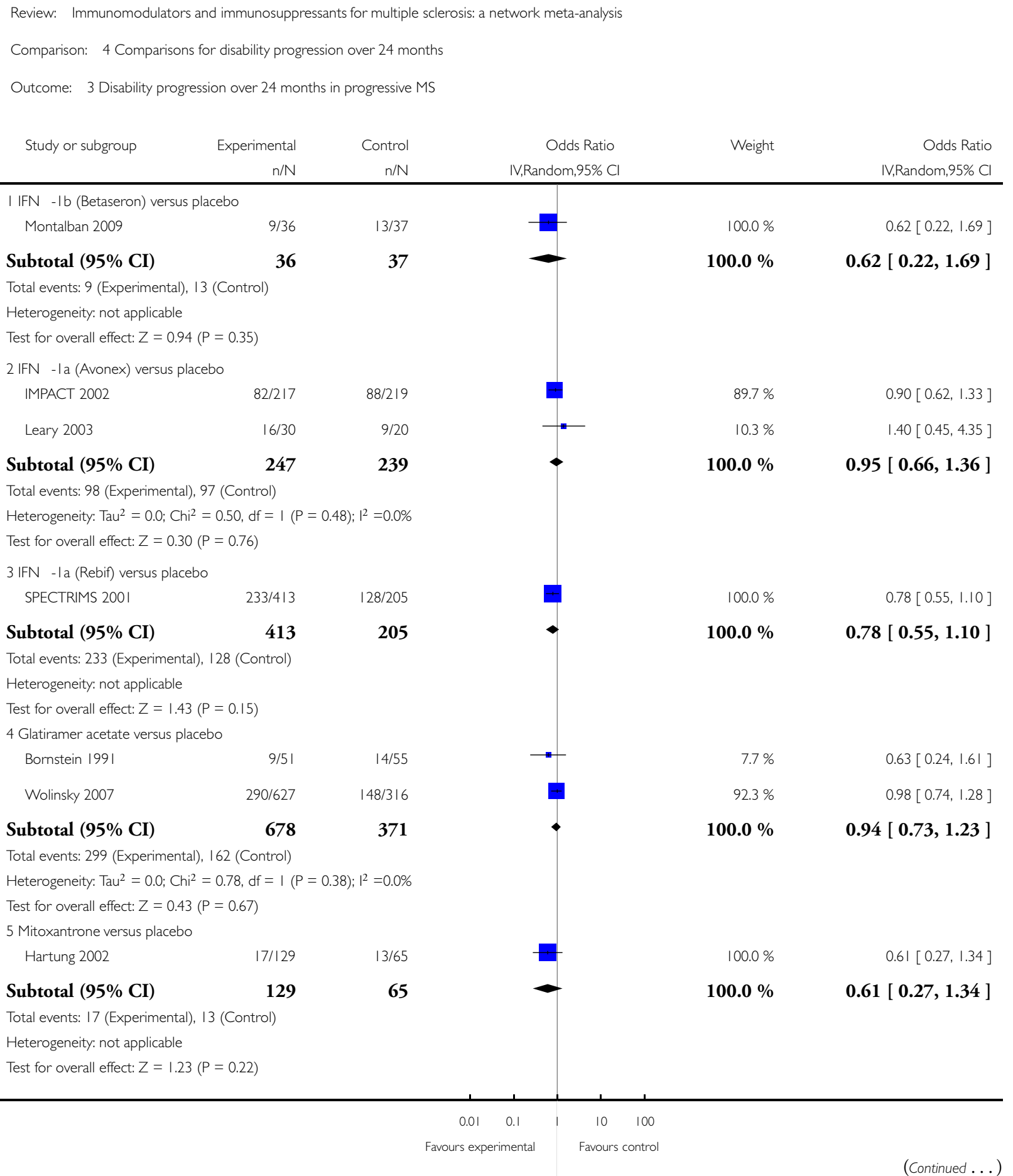




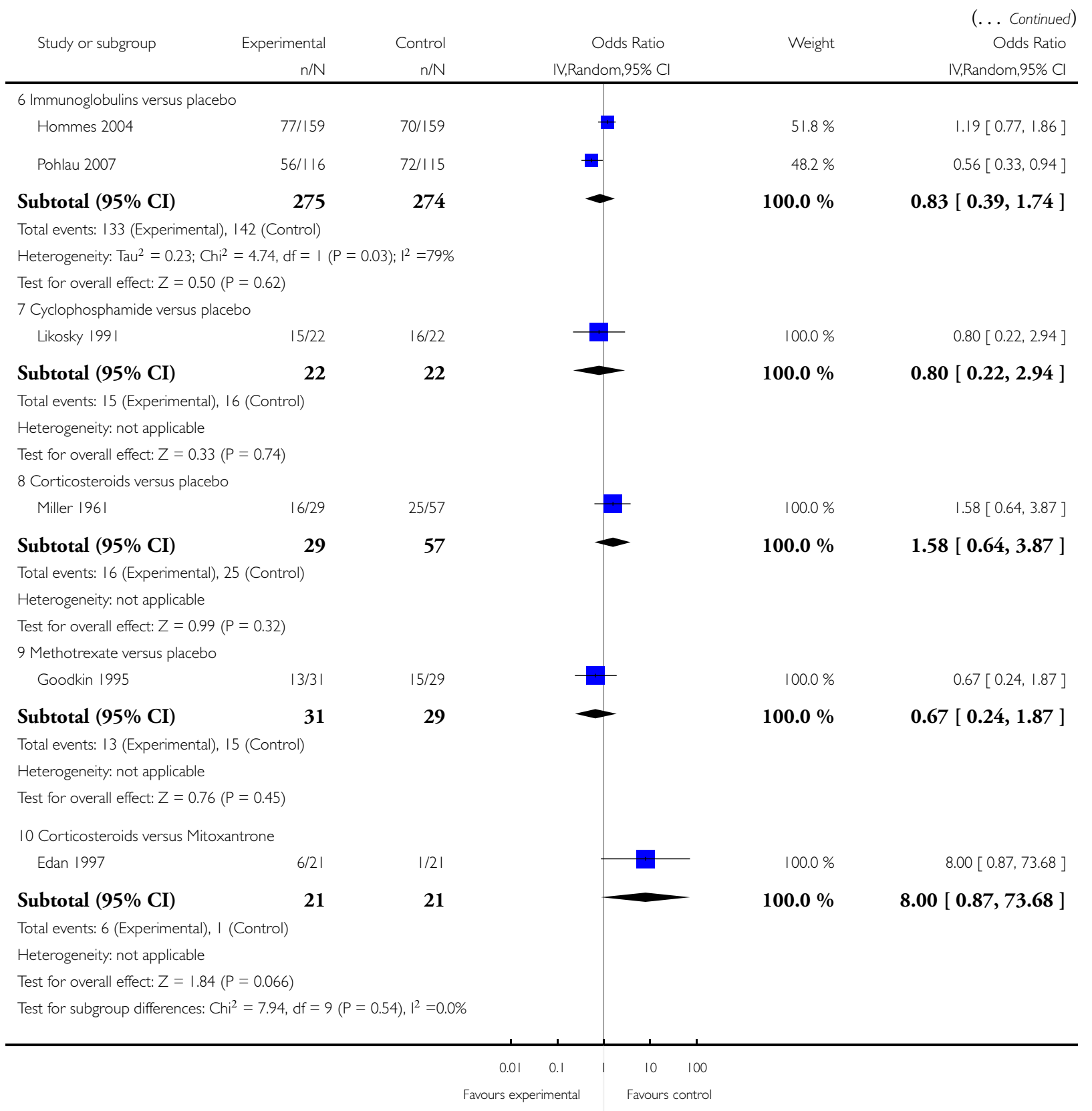


Analysis 5.I. Comparison 5 Comparisons for disability progression over $\mathbf{3 6}$ months, Outcome I Disability progression over 36 months in progressive MS.

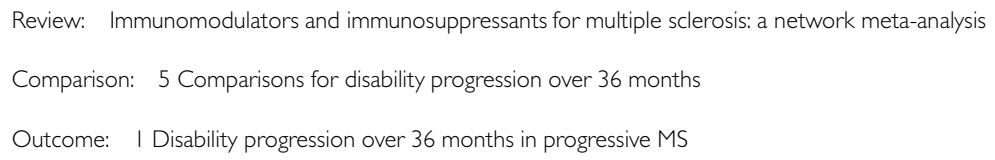

Subtotal $(95 \% \mathrm{CI})$

Total events: 40 (Experimental), 37 (Control)

Heterogeneity: $\operatorname{Tau}^{2}=0.13 ; \mathrm{Chi}^{2}=1.32, \mathrm{df}=\mathrm{I}(\mathrm{P}=0.25) ; \mathrm{I}^{2}=25 \%$

Test for overall effect: $Z=1.62(P=0.11)$

4 Cyclophosphamide versus placebo

$$
\text { CCMSSG 1991 }
$$

Subtotal $(95 \% \mathrm{CI})$

Total events: 29 (Experimental), 23 (Control)

Heterogeneity: not applicable

Test for overall effect: $Z=1.23(P=0.22)$

Test for subgroup differences: $\mathrm{Chi}^{2}=4.64, \mathrm{df}=3(\mathrm{P}=0.20), \mathrm{I}^{2}=35 \%$

$\begin{array}{rr}48.4 \% & 0.70[0.51,0.96] \\ 51.6 \% & 1.08[0.81,1.43]\end{array}$

$100.0 \%$

$0.87[0.57,1.33]$

$48.2 \%$

$51.8 \%$

$100.0 \%$

$70.3 \%$

$29.7 \%$

$100.0 \%$

$100.0 \%$

$100.0 \%$
$1.43[0.94,2.16]$

$0.87[0.60,1.26]$

$1.10[0.68,1.80]$

$0.64[0.28,1.47]$

$0.23[0.05,1.05]$

$0.47[0.19,1.17]$

$1.60[0.76,3.39]$

$1.60[0.76,3.39]$

Favours control 


\section{Analysis 6.I. Comparison 6 Comparison for adverse events, Outcome I Serious adverse events.}

Review: Immunomodulators and immunosuppressants for multiple sclerosis: a network meta-analysis

Comparison: 6 Comparison for adverse events

Outcome: I Serious adverse events

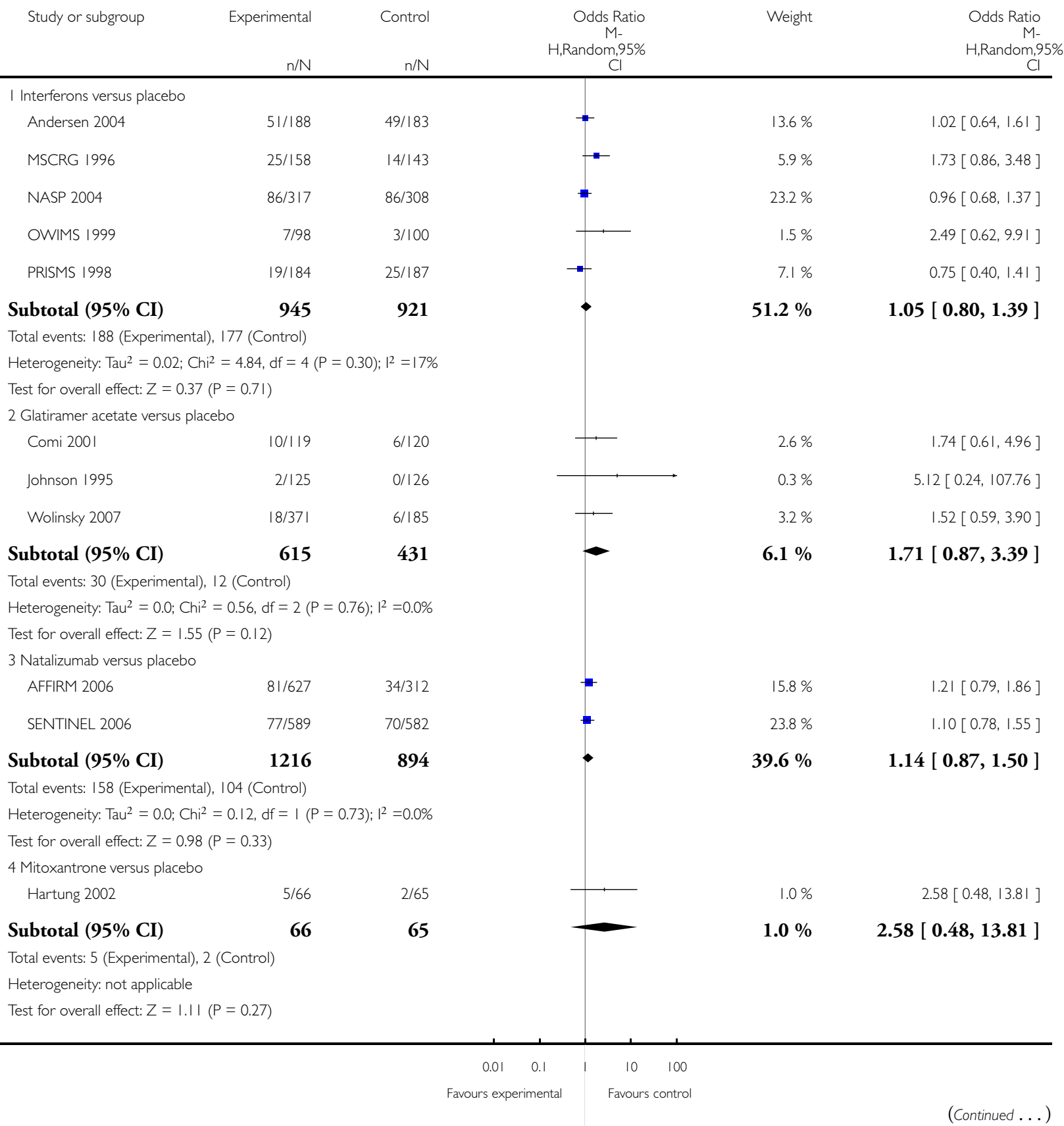




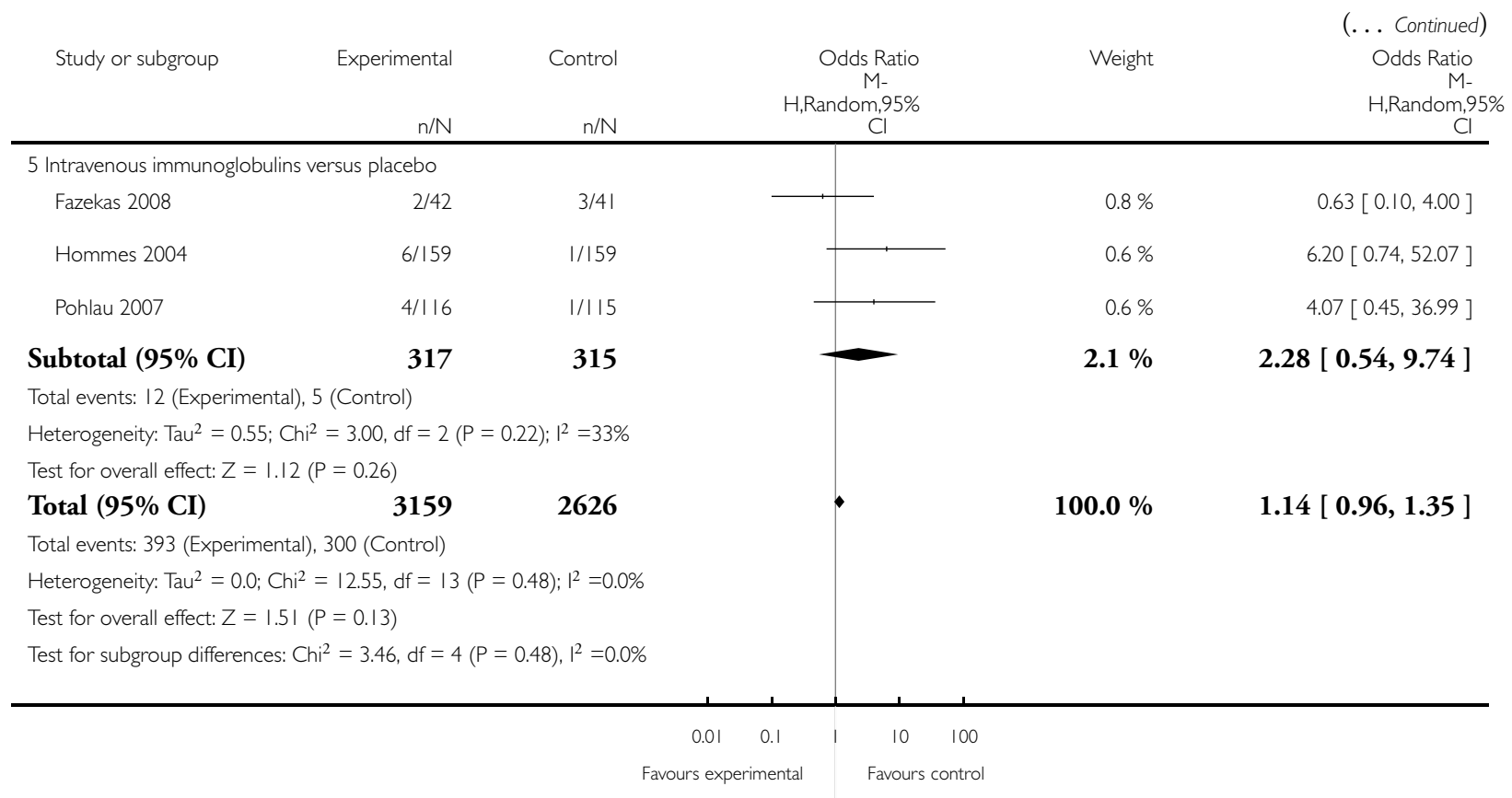




\section{Analysis 6.2. Comparison 6 Comparison for adverse events, Outcome 2 Withdrawals due to adverse events.}

Review: Immunomodulators and immunosuppressants for multiple sclerosis: a network meta-analysis

Comparison: 6 Comparison for adverse events

Outcome: 2 Withdrawals due to adverse events

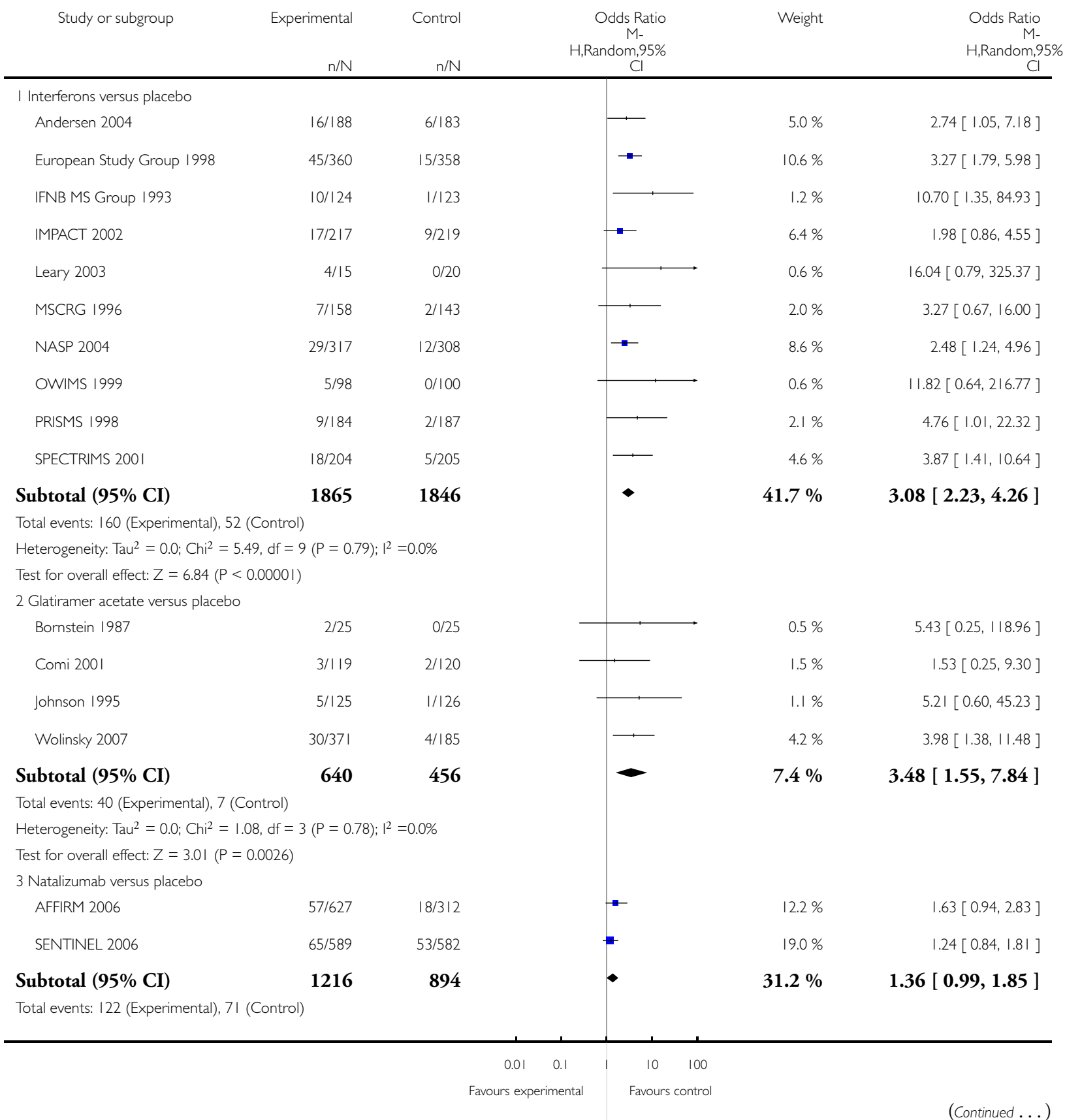




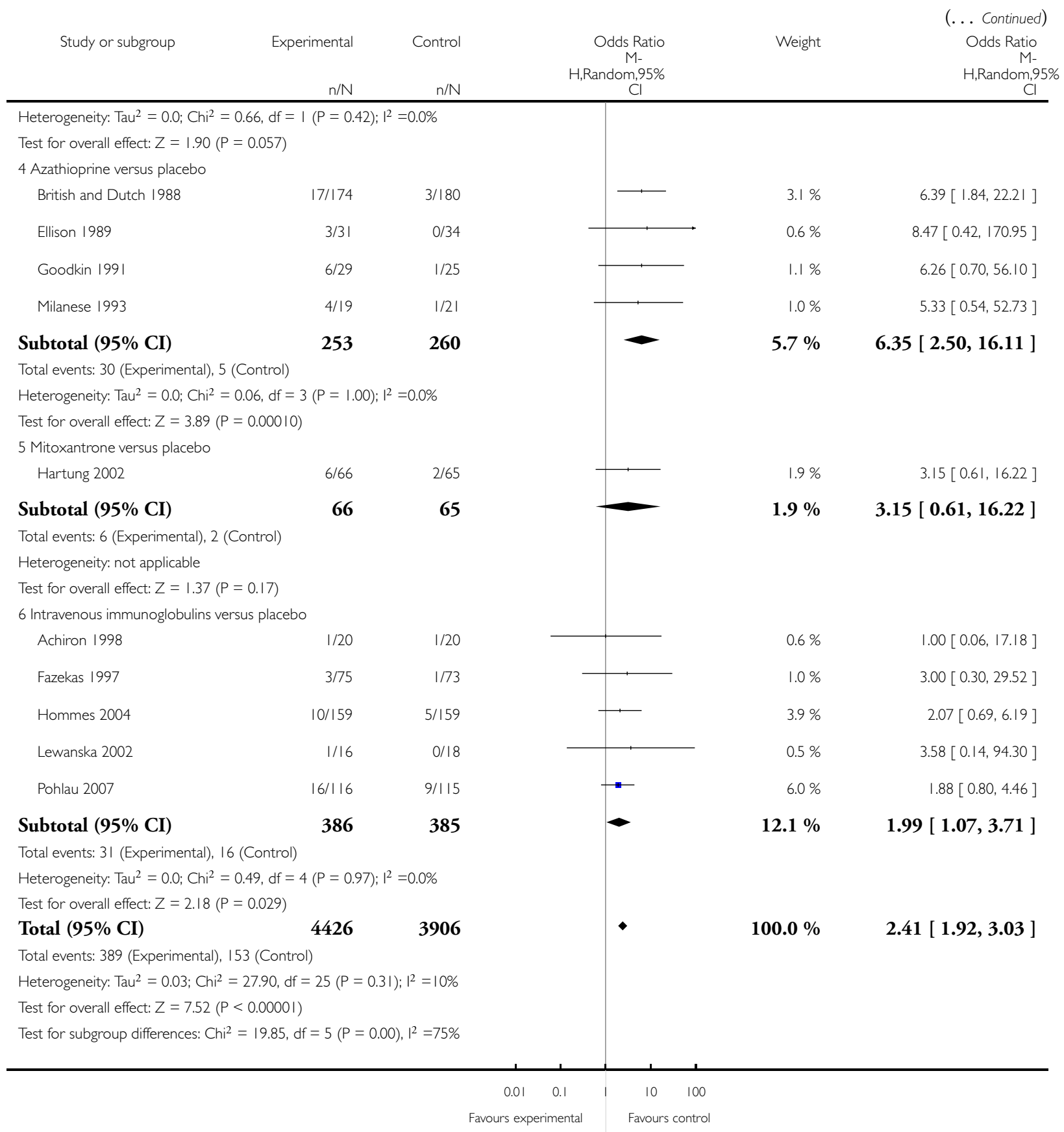


ADDITIONAL TABLES

Table 1. Number of participants in each treatment group

\begin{tabular}{|c|c|c|c|c|c|}
\hline Type of treatment & $\begin{array}{l}\text { RCTs } \\
\mathrm{N}\end{array}$ & $\begin{array}{l}\text { RRMS } \\
\mathrm{N}=9096\end{array}$ & $\begin{array}{l}\text { Progressive MS } \\
N=7726\end{array}$ & $\begin{array}{l}\text { RRMS and } \\
\text { progressive MS } \\
\text { combined } \\
\mathrm{N}=579\end{array}$ & $\begin{array}{l}\text { All MS } \\
N=17401\end{array}$ \\
\hline Azathioprine & 5 & 30 & 65 & 286 & 381 \\
\hline Cyclophosphamide & 2 & 0 & 77 & & 77 \\
\hline Corticosteroids & 3 & 19 & 50 & & 69 \\
\hline Glatiramer acetate & 7 & 1095 & 678 & & 1773 \\
\hline $\begin{array}{l}\text { IFNß-1b } \\
\text { (Betaseron) }\end{array}$ & 9 & 2347 & 1027 & & 3374 \\
\hline IFNß-1a (Avonex) & 7 & 1200 & 2647 & & 3847 \\
\hline IFNß-1a (Rebif) & 8 & 1464 & 601 & & 2065 \\
\hline $\begin{array}{l}\text { IV immunoglobu- } \\
\text { lins }\end{array}$ & 6 & 215 & 275 & & 490 \\
\hline Methotrexate & 1 & 0 & 31 & & 31 \\
\hline Mitoxantrone & 3 & 27 & 150 & & 177 \\
\hline Natalizumab & 2 & 1216 & 0 & & 1216 \\
\hline placebo & 36 & 1483 & 2125 & 293 & 3901 \\
\hline
\end{tabular}

Table 2. Methods of adverse events monitoring

\begin{tabular}{|l|l|l|l|l|}
\hline Study & $\begin{array}{l}\text { Risk of } \\
\text { bias }\end{array}$ & $\begin{array}{l}\text { Did the researchers ac- Risk of bias } \\
\text { tively monitor for adverse } \\
\text { events (AEs) (low risk of } \\
\text { bias) or did they simply } \\
\text { provide spontaneous re- } \\
\text { porting of AEs that arose } \\
\text { (high risk of bias)? }\end{array}$ & $\begin{array}{l}\text { Did the authors define serious AEs } \\
\text { (SAEs) according to an accepted interna- } \\
\text { tional classification and report the num- } \\
\text { ber of SAEs? }\end{array}$ \\
\hline Achiron 1998 & Unclear & Not reported & SAEs not reported \\
\hline AFFIRM 2006 & Low & $\begin{array}{l}\text { "Treating neurologists were re- Unclear } \\
\text { sponsible for all aspects of pa- } \\
\text { tient care, including the man- }\end{array}$ & $\begin{array}{l}\text { Insuffi cient information on SAEs } \\
\text { defi nition }\end{array}$ \\
\hline
\end{tabular}


Table 2. Methods of adverse events monitoring (Continued)

\begin{tabular}{|c|c|c|c|c|}
\hline & & $\begin{array}{l}\text { agement of adverse events". } \\
\text { Participants"visited the clinic } \\
\text { every } 12 \text { weeks for ... blood } \\
\text { chemical and hematologic } \\
\text { analyses, evaluation of adverse } \\
\text { events..." }\end{array}$ & & \\
\hline Andersen 2004 & Low & $\begin{array}{l}\text { "Adverse events and con- } \\
\text { comitant medications were } \\
\text { recorded throughout the study, } \\
\text { and clinical laboratory eval- } \\
\text { uation was performed at } \\
\text { months } 1 \text {, 3, and } 6 \text {, and then } \\
\text { at } 6 \text { monthly evaluation visits } \\
\text { or as needed" }\end{array}$ & Unclear & $\begin{array}{l}\text { Insuffi cient information on SAEs } \\
\text { defi nition }\end{array}$ \\
\hline BEYOND 2009 & Low & $\begin{array}{l}\text { "Clinic visits were scheduled } \\
\text { every } 3 \text { months to assess ... sa- } \\
\text { fety, and tolerability. The oc- } \\
\text { currence of new neurological } \\
\text { symptoms and adverse events } \\
\text { was assessed by telephone, } 6 \\
\text { weeks after each visit" }\end{array}$ & Low & $\begin{array}{l}\text { Categorisation of SAEs conformed to ICH } \\
\text { guidelines (International Conference on } \\
\text { Harmonisation of Technical Requirements } \\
\text { for Registration of Pharmaceuticals for Hu- } \\
\text { man Use) }\end{array}$ \\
\hline Bornstein 1987 & High & $\begin{array}{l}\text { "Self-evaluation reported to a } \\
\text { clinical assistant" }\end{array}$ & High & SAEs not reported \\
\hline Bornstein 1991 & High & $\begin{array}{l}\text { "Self-reporting reported to a } \\
\text { clinical assistant" }\end{array}$ & High & SAEs not reported \\
\hline BPSM 1995 & Unclear & Not reported & Unclear & $\begin{array}{l}\text { Insuffi cient information on SAEs } \\
\text { defi nition }^{\text {nion }}\end{array}$ \\
\hline British and Dutch 1988 & Unclear & $\begin{array}{l}\text { "The occurrence of side effects } \\
\text { was notified to the trial centre } \\
\text { every } 3 \text { months" }\end{array}$ & High & SAEs not reported \\
\hline CCMSSG 1991 & Unclear & $\begin{array}{l}\text { "The external safety monitor- } \\
\text { ing committee monitored the } \\
\text { progress of the trial every } 6 \\
\text { months (severe adverse experi- } \\
\text { ences, deaths, clinical status)" }\end{array}$ & High & SAEs not reported \\
\hline Comi 2001 & Unclear & $\begin{array}{l}\text { "The treating physician mon- } \\
\text { itored safety..." }\end{array}$ & Unclear & $\begin{array}{l}\text { Insuffi cient information on SAEs } \\
\text { defi nition }\end{array}$ \\
\hline Edan 1997 & Unclear & Not reported & Unclear & $\begin{array}{l}\text { Insuffi cient information on SAEs } \\
\text { defi nition }\end{array}$ \\
\hline
\end{tabular}


Table 2. Methods of adverse events monitoring (Continued)

\begin{tabular}{|c|c|c|c|c|}
\hline Ellison 1989 & Low & $\begin{array}{l}\text { Participants"were instructed } \\
\text { to call the clinic anytime they } \\
\text { suspected an adverse events } \\
\text { and then actively monitored } \\
\text { by neurologist" }\end{array}$ & High & SAEs not reported \\
\hline Etemadifar 2006 & High & $\begin{array}{l}\text { "Given the lack of safety assess- } \\
\text { ment of this trial, it is impor- } \\
\text { tant to recall that the safety of } \\
\text { IFN-b products in the treat- } \\
\text { ment of RRMS had already } \\
\text { been established for the three } \\
\text { drugs in previous studies" }\end{array}$ & High & SAEs not reported \\
\hline $\begin{array}{l}\text { European Study Group } \\
1998\end{array}$ & Low & $\begin{array}{l}\text { "Safety assessments included } \\
\text { adverse events, vital signs, } \\
\text { physical examinations, and } \\
\text { concomitant medication. An } \\
\text { independent advisory com- } \\
\text { mittee reviewed the results of } \\
\text { regular interim safety analyses } \\
\text { done after all participantshad } \\
\text { been in the study for at least } \\
24 \text { months" }\end{array}$ & High & SAEs not reported \\
\hline EVIDENCE 2007 & High & $\begin{array}{l}\text { "Adverse events were deter- } \\
\text { mined by spontaneous report- } \\
\text { ing and monthly laboratory } \\
\text { testing during the comparative } \\
\text { phase" }\end{array}$ & Unclear & $\begin{array}{l}\text { Insuffi cient information on SAEs } \\
\text { defi nition }^{\text {nition }}\end{array}$ \\
\hline Fazekas 1997 & Low & $\begin{array}{l}\text { Participants" asked about sa- } \\
\text { fety monthly..." }\end{array}$ & High & SAEs not reported \\
\hline Fazekas 2008 & Unclear & Not reported & Unclear & $\begin{array}{l}\text { Insuffi cient information on SAEs } \\
\text { defi nition }^{\text {nition }}\end{array}$ \\
\hline Ghezzi 1989 & Unclear & Not reported & High & SAEs not reported \\
\hline Goodkin 1991 & High & $\begin{array}{l}\text { "Side effect were reported to } \\
\text { the treating neurologist every } \\
6 \text { months" }\end{array}$ & High & SAEs not reported \\
\hline Goodkin 1995 & Low & $\begin{array}{l}\text { "All participantsmaintained } \\
\text { a daily diary of undesirable } \\
\text { events... The adverse event } \\
\text { diary was checked every } 3 \\
\text { months by the studynurse dur- } \\
\text { ing a clinical visit" }\end{array}$ & High & SAEs not reported \\
\hline
\end{tabular}


Table 2. Methods of adverse events monitoring

\begin{tabular}{|c|c|c|c|c|}
\hline Hartung 2002 & Unclear & Not reported & Unclear & $\begin{array}{l}\text { Insuffi cient information on SAEs } \\
\text { defi nition }\end{array}$ \\
\hline Hommes 2004 & Unclear & $\begin{array}{l}\text { "Several safety laboratory tests } \\
\text { were done..." }\end{array}$ & Unclear & $\begin{array}{l}\text { Insuffi cient information on SAEs } \\
\text { defi nition }\end{array}$ \\
\hline IFNB MS Group 1993 & Low & $\begin{array}{l}\text { "Treating neurologist re- } \\
\text { viewed side effects, laboratory } \\
\text { findings for toxicity ..." }\end{array}$ & High & SAEs not reported \\
\hline IMPACT 2002 & Unclear & $\begin{array}{l}\text { "An in- } \\
\text { dependent external Data and } \\
\text { Safety Monitoring Committee } \\
\text { reviewed safety data at three } \\
\text { time points during the trial } \\
\text { and performed a preplanned } \\
\text { interim analysis after all sub- } \\
\text { jects had been followed for } 15 \\
\text { months" }\end{array}$ & High & SAEs not reported \\
\hline INCOMIN 2002 & Low & $\begin{array}{l}\text { "Sa- } \\
\text { fety assessments included ad- } \\
\text { verse events, vital signs, phys- } \\
\text { ical examination, and con- } \\
\text { comitant medications. Par- } \\
\text { ticipantsunderwent haema- } \\
\text { tology and biochemical tests, } \\
\text { including liver-function tests, } \\
\text { every } 2 \text { weeks for the first } \\
8 \text { weeks, and then every } 3 \\
\text { months" }\end{array}$ & High & SAEs not reported \\
\hline Johnson 1995 & Low & $\begin{array}{l}\text { "The evaluating physician } \\
\text { monitored safety every } 3 \\
\text { month..." }\end{array}$ & Unclear & $\begin{array}{l}\text { Insuffi cient information on SAEs } \\
\text { defi nition }\end{array}$ \\
\hline Knobler 1993 & Unclear & Not reported & High & SAEs not reported \\
\hline Koch-Henriksen 2006 & Low & $\begin{array}{l}\text { Partici- } \\
\text { pants"were interviewed about } \\
\text { side effects and had routine } \\
\text { blood tests including hematol- } \\
\text { ogy and liver function tests } \\
\text { every } 3 \text { months and thyroid } \\
\text { tests and neutralizing anti- } \\
\text { bodies every } 6 \text { months" }\end{array}$ & High & SAEs not reported \\
\hline
\end{tabular}


Table 2. Methods of adverse events monitoring (Continued)

\begin{tabular}{|c|c|c|c|c|}
\hline Leary 2003 & Low & $\begin{array}{l}\text { "AEs were monitored through- } \\
\text { out the study..." }\end{array}$ & High & SAEs not reported \\
\hline Lewanska 2002 & Unclear & $\begin{array}{l}\text { "Laboratory safety examina- } \\
\text { tions were made at the begin- } \\
\text { ning and at the end of the } \\
\text { study period" }\end{array}$ & Unclear & $\begin{array}{l}\text { Insuffi cient information on SAEs } \\
\text { defi nition }\end{array}$ \\
\hline Likosky 1991 & Unclear & Not reported & High & SAEs not reported \\
\hline Milanese 1993 & Unclear & Not reported & High & SAEs not reported \\
\hline Millefiorini 1997 & Low & $\begin{array}{l}\text { "The safety of the treatment } \\
\text { was assessed on the basis of ad- } \\
\text { verse events volunteered by the } \\
\text { patient either spontaneouslyor } \\
\text { on questioning and monitor- } \\
\text { ing of the main laboratory pa- } \\
\text { rameters" }\end{array}$ & Unclear & $\begin{array}{l}\text { Insuffi cient information on SAEs } \\
\text { defi nition }^{\text {nation }}\end{array}$ \\
\hline Miller 1961 & Low & $\begin{array}{l}\text { "An independent observer un- } \\
\text { connected with the trial, ob- } \\
\text { served every } \\
\text { months the prednisolone par- } \\
\text { ticipantsto detect toxic effects" }\end{array}$ & High & SAEs not reported \\
\hline Montalban 2009 & Low & $\begin{array}{l}\text { "Safety issues during the study } \\
\text { were monitored by an in- } \\
\text { dependent Safety Committee. } \\
\text { Participantswere asked to re- } \\
\text { port any adverse event,... the } \\
\text { presence of adverse events and } \\
\text { intercurrent illnesses was as- } \\
\text { sessed at all visits" }\end{array}$ & High & SAEs not reported \\
\hline MSCRG 1996 & Low & $\begin{array}{l}\text { "According to the FDA phase } \\
\text { III requirements..." }\end{array}$ & Unclear & $\begin{array}{l}\text { Insuffi cient information on SAEs } \\
\text { defi nition }\end{array}$ \\
\hline NASP 2004 & Unclear & $\begin{array}{l}\text { "As required by protocol, an } \\
\text { Independent Data and Safety } \\
\text { Monitoring Board (IDSMB) } \\
\text { reviewed interim safety data } \\
\text { every } 6 \text { months" }\end{array}$ & Unclear & $\begin{array}{l}\text { Insuffi cient information on SAEs } \\
\text { defi nition }\end{array}$ \\
\hline OWIMS 1999 & Unclear & $\begin{array}{l}\text { "The treating physician } \\
\text { recorded and treated AEs..." }\end{array}$ & Unclear & $\begin{array}{l}\text { Insuffi cient information on SAEs } \\
\text { defi nition }\end{array}$ \\
\hline
\end{tabular}


Table 2. Methods of adverse events monitoring (Continued)

\begin{tabular}{|c|c|c|c|c|}
\hline Pohlau 2007 & Low & $\begin{array}{l}\text { "Safety and tolerability of the } \\
\text { treatment were assessed by } \\
\text { recording adverse events, vital } \\
\text { signs and by laboratory find- } \\
\text { ings. All adverse events and } \\
\text { clinical symptoms related to } \\
\text { the disease or the study med- } \\
\text { ication were recorded every } 4 \\
\text { weeks" }\end{array}$ & Unclear & $\begin{array}{l}\text { Insuffi cient information on SAEs } \\
\text { defi nition }\end{array}$ \\
\hline PRISMS 1998 & Unclear & $\begin{array}{l}\text { "The treating physician } \\
\text { treated AEs..." }\end{array}$ & Unclear & $\begin{array}{l}\text { Insuffi cient information on SAEs } \\
\text { defi nition }^{\text {nition }}\end{array}$ \\
\hline REGARD 2008 & Unclear & $\begin{array}{l}\text { "Adverse events (including } \\
\text { pregnancy), withdrawals ow- } \\
\text { ing to adverse events, serious } \\
\text { adverse events, and laboratory } \\
\text { results were obtained for safety } \\
\text { comparisons" }\end{array}$ & Unclear & $\begin{array}{l}\text { Insuffi cient information on SAEs } \\
\text { defi nition }\end{array}$ \\
\hline SENTINEL 2006 & Low & $\begin{array}{l}\text { The treating neurologists were } \\
\text { responsible for all patient care, } \\
\text { including the management of } \\
\text { adverse events and relapses of } \\
\text { multiple sclerosis. Clinical vis- } \\
\text { its every } 12 \text { weeks included } \\
\text { (...) assessment of any adverse } \\
\text { events. Participantswere also } \\
\text { seen by a treating neurolo- } \\
\text { gist during unscheduled vis- } \\
\text { its within } 72 \text { hours after the } \\
\text { development of new symptoms } \\
\text { so that they could be assessed } \\
\text { for possible relapses or adverse } \\
\text { events" }\end{array}$ & Unclear & $\begin{array}{l}\text { Insuffi cient information on SAEs } \\
\text { defi nition }\end{array}$ \\
\hline SPECTRIMS 2001 & Low & $\begin{array}{l}\text { "A treating physician super- } \\
\text { vised drug administration, } \\
\text { monitored safety, and man- } \\
\text { aged adverse events" }\end{array}$ & High & SAEs not reported \\
\hline Wolinsky 2007 & Low & $\begin{array}{l}\text { "The treating neurologist su- } \\
\text { pervised drug administration, } \\
\text { recorded and treated adverse } \\
\text { events" }\end{array}$ & Unclear & $\begin{array}{l}\text { Insuffi cient information on SAEs } \\
\text { defi nition }^{\text {nition }}\end{array}$ \\
\hline
\end{tabular}


Table 3. Model fit and parsimony measures for all the primary outcomes

\begin{tabular}{l|l|l|l|l}
\hline & $\begin{array}{l}\text { Posterior Residual } \\
\text { Deviance } \\
\text { (consistency model) }\end{array}$ & $\begin{array}{l}\text { Data } \\
\text { Points }\end{array}$ & $\begin{array}{l}\text { DIC } \\
\text { (consistency model) }\end{array}$ & $\begin{array}{l}\text { DIC } \\
\text { (inconsistency model) }\end{array}$ \\
\hline $\begin{array}{l}\text { Recurrence of relapses } \\
\text { over } 12 \text { months }\end{array}$ & 45 & 42 & 83 & 84 \\
\hline $\begin{array}{l}\text { Recurrence of relapses } \\
\text { over 24 months }\end{array}$ & 60 & 51 & 104 & 106 \\
\hline \begin{tabular}{l} 
Relapses over 36 months \\
\hline progression
\end{tabular} & 60 & 12 & 22 & 112 \\
\hline $\begin{array}{l}\text { Disability } \\
\text { over 24 months }\end{array}$ & 60 & 109 & 22 \\
\hline $\begin{array}{l}\text { Disability progression } \\
\text { over 36 months }\end{array}$ & 14 & 14 & 28 & 86 \\
\hline \begin{tabular}{l} 
Acceptability \\
\hline
\end{tabular} & 54 & 57 & 85 & 28 \\
\hline
\end{tabular}

Table 4. Network meta-analysis: summary results for recurrence of relapses at any time point, posterior ORs and their $95 \%$ credible intervals of all active interventions versus placebo and SUCRA values

\begin{tabular}{|c|c|c|c|c|c|c|}
\hline & \multicolumn{2}{|c|}{$\begin{array}{l}\text { Recurrence of relapses } \\
\text { over } 12 \text { months }\end{array}$} & \multicolumn{2}{|c|}{$\begin{array}{l}\text { Recurrence of relapses } \\
\text { over } 24 \text { months }\end{array}$} & \multicolumn{2}{|c|}{$\begin{array}{l}\text { Recurrence of relapses } \\
\text { over } 36 \text { months }\end{array}$} \\
\hline & $\begin{array}{l}\text { Median OR } \\
(95 \% \mathrm{CrI})\end{array}$ & SUCRA & $\begin{array}{l}\text { Median OR } \\
(95 \% \mathrm{CrI})\end{array}$ & SUCRA & $\begin{array}{l}\text { Median OR } \\
(95 \% \mathrm{CrI})\end{array}$ & SUCRA \\
\hline Natalizumab & $\begin{array}{l}0.35 \\
(0.12 \text { to } 1.06)\end{array}$ & $72 \%$ & $\begin{array}{l}0.29 \\
(0.17 \text { to } 0.51)\end{array}$ & $92 \%$ & - & - \\
\hline IFNß-1a (Rebif) & $\begin{array}{l}0.65 \\
(0.27 \text { to } 1.59)\end{array}$ & $40 \%$ & $\begin{array}{l}0.44 \\
(0.24 \text { to } 0.70)\end{array}$ & $73 \%$ & $\begin{array}{l}1.28 \\
(0.40 \text { to } 4.05)\end{array}$ & $13 \%$ \\
\hline Mitoxantrone & $\begin{array}{l}0.12 \\
(0.03 \text { to } 0.55)\end{array}$ & $95 \%$ & $\begin{array}{l}0.43 \\
(0.20 \text { to } 0.87)\end{array}$ & $71 \%$ & - & - \\
\hline $\begin{array}{l}\text { Glatiramer } \\
\text { acetate }\end{array}$ & $\begin{array}{l}0.40 \\
(0.11 \text { to } 1.15)\end{array}$ & $65 \%$ & $\begin{array}{l}0.48 \\
(0.38 \text { to } 0.75)\end{array}$ & $66 \%$ & - & - \\
\hline $\begin{array}{l}\text { IFNß-1b } \\
\text { (Betaseron) }\end{array}$ & $\begin{array}{l}0.54 \\
(0.14 \text { to } 2.15)\end{array}$ & $50 \%$ & $\begin{array}{l}0.48 \\
(0.29 \text { to } 0.78)\end{array}$ & $65 \%$ & $\begin{array}{l}0.69 \\
(0.29 \text { to } 1.47)\end{array}$ & $64 \%$ \\
\hline Azathioprine & $\begin{array}{l}0.63 \\
(0.27 \text { to } 1.45)\end{array}$ & $42 \%$ & $\begin{array}{l}0.63 \\
(0.39 \text { to } 0.97)\end{array}$ & $46 \%$ & $\begin{array}{l}0.43 \\
(0.17 \text { to } 0.88)\end{array}$ & $94 \%$ \\
\hline
\end{tabular}


Table 4. Network meta-analysis: summary results for recurrence of relapses at any time point, posterior ORs and their 95\% credible intervals of all active interventions versus placebo and SUCRA values (Continued)

\begin{tabular}{|c|c|c|c|c|c|c|}
\hline $\begin{array}{l}\text { Immunoglobu- } \\
\text { lins }\end{array}$ & $\begin{array}{l}0.61 \\
(0.22 \text { to } 1.31)\end{array}$ & $44 \%$ & $\begin{array}{l}0.69 \\
(0.40 \text { to } 1.04)\end{array}$ & $41 \%$ & - & - \\
\hline Corticosteroids & $\begin{array}{l}0.48 \\
(0.10 \text { to } 2.29)\end{array}$ & $53 \%$ & $\begin{array}{l}1.13 \\
(0.03 \text { to } 47.93)\end{array}$ & $36 \%$ & - & - \\
\hline Methotrexate & - & - & $\begin{array}{l}1.16 \\
(0.27 \text { to } 5.35)\end{array}$ & $23 \%$ & - & - \\
\hline $\begin{array}{l}\text { IFNß-1a } \\
\text { (Avonex) }\end{array}$ & $\begin{array}{l}0.81 \\
(0.33 \text { to } 1.99)\end{array}$ & $26 \%$ & $\begin{array}{l}0.96 \\
(0.64 \text { to } 1.50)\end{array}$ & $19 \%$ & - & - \\
\hline
\end{tabular}

SUCRA: Surface below the Cumulative Ranking Curve. The larger the SUCRA value for a treatment, the higher its rank among the available treatment options.

Table 5. Network meta-analysis: summary results for disability progression at any time point, posterior ORs and their $95 \%$ credible intervals of all active intervnetions versus placebo and SUCRA values

\begin{tabular}{|c|c|c|c|c|}
\hline & \multicolumn{2}{|c|}{$\begin{array}{l}\text { Disability progression over } 24 \\
\text { months }\end{array}$} & \multicolumn{2}{|c|}{ Disability progression over 36 months } \\
\hline & Median OR (95\%CrI) & SUCRA & Median OR $(95 \% \mathrm{CrI})$ & SUCRA \\
\hline Mitoxantrone & $0.42(0.20$ to 0.87$)$ & $89 \%$ & - & - \\
\hline Natalizumab & $0.61(0.41$ to 0.91$)$ & $74 \%$ & - & - \\
\hline Glatiramer acetate & $0.67(0.49$ to 0.88$)$ & $67 \%$ & - & - \\
\hline Methotrexate & $0.67(0.22$ to 2.04$)$ & $58 \%$ & - & - \\
\hline Immunoglobulins & 0.79 (0.53 to 1.17$)$ & $58 \%$ & - & - \\
\hline IFNß-1b (Betaseron) & $0.74(0.54$ to 1.00$)$ & $54 \%$ & $0.87(0.35$ to 2.09$)$ & $59 \%$ \\
\hline Azathioprine & $0.75(0.42$ to 1.30$)$ & $54 \%$ & $0.45(0.13$ to 1.31$)$ & $92 \%$ \\
\hline Cyclophosphamide & $0.79(0.19$ to 3.27$)$ & $49 \%$ & $1.62(0.40$ to 6.56$)$ & $18 \%$ \\
\hline IFNß-1a (Rebif) & $0.79(0.60$ to 1.04$)$ & $47 \%$ & $1.10(0.45$ to 2.79$)$ & $36 \%$ \\
\hline IFNß-1a (Avonex) & $1.06(0.78$ to 1.51$)$ & $18 \%$ & - & - \\
\hline Corticosteroids & $1.58(0.58$ to 4.35$)$ & $11 \%$ & - & - \\
\hline
\end{tabular}

SUCRA: Surface below the Cumulative Ranking Curve. The larger the SUCRA value for a treatment, the higher its rank among the available treatment options.

Immunomodulators and immunosuppressants for multiple sclerosis: a network meta-analysis (Review)

Copyright $\Subset 2013$ The Cochrane Collaboration. Published by John Wiley \& Sons, Ltd. 
Table 6. Network meta-analysis: summary results for patients with RRMS for recurrence of relapses over 12 and 24 months and disability progression over 24 months, posterior ORs (95\% credible intervals) of all active interventions versus placebo and SUCRA values

\begin{tabular}{|c|c|c|c|c|c|c|}
\hline & \multicolumn{2}{|c|}{$\begin{array}{l}\text { Recurrence of relapses } \\
\text { over } 12 \text { months }\end{array}$} & \multicolumn{2}{|c|}{$\begin{array}{l}\text { Recurrence of relapses } \\
\text { over } 24 \text { months }\end{array}$} & \multicolumn{2}{|l|}{$\begin{array}{l}\text { Disability progression } \\
\text { over } 24 \text { months }\end{array}$} \\
\hline & $\begin{array}{ll}\text { Median } & \text { OR } \\
(95 \% \mathrm{CrI}) & \end{array}$ & SUCRA & $\begin{array}{l}\text { Median } \\
(95 \% \mathrm{CrI})\end{array}$ & SUCRA & Median OR (95\%CrI) & SUCRA \\
\hline Mitoxantrone & $\begin{array}{l}0.13(0.01 \text { to } 1 . \\
32)\end{array}$ & $85 \%$ & $0.14(0.03$ to 0.55$)$ & $92 \%$ & $0.11(0.01$ to 0.65$)$ & $96 \%$ \\
\hline Natalizumab & $\begin{array}{l}0.35(0.07 \text { to } 1 . \\
67)\end{array}$ & $65 \%$ & $0.31(0.19$ to 0.55$)$ & $75 \%$ & $0.62(0.33$ to 1.24$)$ & $55 \%$ \\
\hline $\begin{array}{l}\text { Immunoglobu- } \\
\text { lins }\end{array}$ & $\begin{array}{l}0.36(0.08 \text { to } 1 \text {. } \\
28)\end{array}$ & $63 \%$ & $0.34(0.13$ to 0.69$)$ & $70 \%$ & $0.63(0.24$ to 1.67$)$ & $52 \%$ \\
\hline Azathioprine & $\begin{array}{l}0.76(0.08 \text { to } 7 . \\
40)\end{array}$ & $36 \%$ & $0.34(0.08$ to 1.30$)$ & $65 \%$ & $0.51(0.13$ to 1.95$)$ & $61 \%$ \\
\hline IFNß-1a (Rebif) & $\begin{array}{l}0.65(0.19 \text { to } 2 . \\
29)\end{array}$ & $46 \%$ & $0.46(0.25$ to 0.71$)$ & $53 \%$ & 0.74 (0.40 to 1.32$)$ & $40 \%$ \\
\hline $\begin{array}{l}\text { Glatiramer } \\
\text { acetate }\end{array}$ & $\begin{array}{l}0.36(0.07 \text { to } 1 . \\
54)\end{array}$ & $63 \%$ & $0.50(0.29$ to 0.71$)$ & $46 \%$ & $0.52(0.28$ to 0.88$)$ & $70 \%$ \\
\hline $\begin{array}{l}\text { IFNß-1b } \\
\text { (Betaseron) }\end{array}$ & $\begin{array}{l}0.54(0.09 \text { to } 3 . \\
33)\end{array}$ & $47 \%$ & $0.50(0.31$ to 0.82$)$ & $45 \%$ & 0.67 (0.38 to 1.13$)$ & $50 \%$ \\
\hline Corticosteroids & $\begin{array}{l}0.44(0.04 \text { to } 4 . \\
86)\end{array}$ & $54 \%$ & $\begin{array}{l}1.17(0.02 \text { to } 50 . \\
83)\end{array}$ & $31 \%$ & - & - \\
\hline $\begin{array}{l}\text { IFNß-1a } \\
\text { (Avonex) }\end{array}$ & $\begin{array}{l}0.81(0.23 \text { to } 2 . \\
90)\end{array}$ & $29 \%$ & $1.10(0.69$ to 1.82$)$ & $10 \%$ & $1.11(0.64$ to 2.16$)$ & $10 \%$ \\
\hline
\end{tabular}

SUCRA: Surface below the Cumulative Ranking Curve. The larger the SUCRA value for a treatment, the higher its rank among the available treatment options.

Table 7. Network meta-analysis: summary results for patients who dropped out (withdrawals or lost to follow-up) due to adverse events (posterior ORs and 95\% credible intervals of all active interventions versus placebo and SUCRA values)

\begin{tabular}{|c|c|c|}
\hline & Median OR (95\%CrI) & SUCRA \\
\hline Cyclophosphamide & $0.51(0.08$ to 2.75$)$ & $82 \%$ \\
\hline Mitoxantrone & $0.70(0.31$ to 1.56$)$ & $81 \%$ \\
\hline
\end{tabular}


Table 7. Network meta-analysis: summary results for patients who dropped out (withdrawals or lost to follow-up) due to adverse events (posterior ORs and 95\% credible intervals of all active interventions versus placebo and SUCRA values) (Continued)

\begin{tabular}{lll}
\hline Glatiramer acetate & $0.93(0.69$ to 1.25$)$ & $70 \%$ \\
\hline IFNß-1b (Betaseron) & $0.94(0.72$ to 1.22$)$ & $69 \%$ \\
\hline Natalizumab & $1.04(0.52$ to 2.17$)$ & $57 \%$ \\
\hline Azathioprine & $1.34(0.39$ to 4.82$)$ & $43 \%$ \\
\hline Immunoglobulins & $1.23(0.82$ to 1.84$)$ & $40 \%$ \\
\hline IFNß-1a (Rebif) & $1.23(0.85$ to 1.74$)$ & $39 \%$ \\
\hline IFNß-1a (Avonex) & $1.37(0.86$ to 2.25$)$ & $32 \%$ \\
\hline Corticosteroids & $2.95(0.62$ to 17.66$)$ & $17 \%$ \\
\hline Methotrexate & $4.37(0.86$ to 37.96$)$ & $8 \%$ \\
\hline
\end{tabular}

SUCRA: Surface below the Cumulative Ranking Curve. The larger the SUCRA value for a treatment, the higher its rank among the available treatment options.

\section{A P PENDICES}

\section{Appendix I. Search Strategy for CDSR}

\#1MeSH descriptor Multiple Sclerosis, this term only

\#2MeSH descriptor Multiple Sclerosis, Chronic Progressive, this term only

\#3MeSH descriptor Multiple Sclerosis, Relapsing-Remitting, this term only

\#4MeSH descriptor Myelitis, Transverse explode trees 3, 5 and 7

\#5MeSH descriptor Optic Neuritis explode all trees

\#6MeSH descriptor Encephalomyelitis, Acute Disseminated, this term only

\#7MeSH descriptor Demyelinating Autoimmune Diseases, CNS, this term only

\#8“multiple sclerosis":ti,ab,kw or “chronic progressive multiple sclerosis”:ti,ab,kw or "progressive relapsing multiple sclerosis”:ti,ab,kw or "secondary progressive multiple sclerosis":ti,ab,kw or "primary progressive multiple sclerosis":ti,ab,kw

\#9“relapsing remitting multiple sclerosis":ti,ab,kw or "remitting-relapsing multiple sclerosis":ti,ab,kw or "acute relapsing multiple sclerosis":ti,ab,kw or "neuromyelitis optica”:ti,ab,kw or "optic neuritis":ti,ab,kw

\#10“devic disease”:ti,ab,kw or "demyelinating disease”:ti,ab,kw or (adem):ti,ab,kw or “demyelinating disorder”:ti,ab,kw or "clinically isolated syndrome":ti,ab,kw

\#11“transverse myelitis":ti,ab,kw or “acute disseminated encephalomyelitis":ti,ab,kw or (encephalomyelitis):ti,ab,kw

$\# 12 \mathrm{MeSH}$ descriptor Demyelinating Diseases, this term only

\#13(\#1 OR \#2 OR \#3 OR \#4 OR \#5 OR \#6 OR \#7 OR \#8 OR \#9 OR \#10 OR \#11 OR \#12)

$\# 14(\# 13)$ in Cochrane Reviews 


\section{Appendix 2. Keywords for searching for direct comparison studies}

\section{Interferon v Glatiramer Acetate}

\{interferon $1^{*}$ \} OR \{interferon beta\} OR \{beta-1 interferon\} OR \{beta 1 interferon\} OR \{interferon beta- $\left.11^{*}\right\}$ OR $\{$ rebif $\}$ OR $\{$ avonex

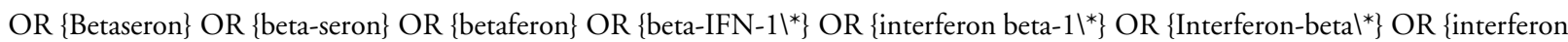
betal*\} OR \{recombinant interferon beta- $\left.11^{*}\right\}$

AND

\{copolymer-1\} OR \{cop-1\} OR \{copaxone OR \{glatiramer acetate OR $\{$ cpx $\}$ OR $\{$ cop1\} OR $\{$ copolymer OR $\{$ glatiramer $\}$ OR \{immunomodulation $\left.{ }^{*}\right\}$ OR $\left\{\right.$ immunomodulator $\left.\left.\right|^{*}\right\}$ OR \{immunosuppression $\}$

\section{Interferon v Methotrexate}

\{interferon $\left.1^{*}\right\}$ OR interferon beta\} OR \{beta-1 interferon\} OR \{beta 1 interferon\} OR \{interferon beta- $\left.11^{*}\right\}$ OR \{rebif $\}$ OR $\{$ avonex $\}$

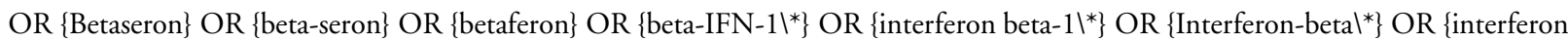
betal*\} OR \{recombinant interferon beta- $\left.11^{*}\right\}$

AND

\{methotrexate OR \{mexate\} OR \{dicesium salt methotrexate\} OR \{disodium salt methotrexate OR \{sodium salt methotrexate OR \{methotrexate hydrate\} OR \{(D)-isomer methotrexate OR \{(DL)-isomer methotrexate\}

\section{Interferon v Azathioprine}

\{interferon $\left.1^{*}\right\}$ OR $\left\{\right.$ interferon beta\} OR $\left\{\right.$ beta- 1 interferon\} OR \{beta 1 interferon\} OR \{interferon beta- $\left.11^{*}\right\}$ OR $\{$ rebif $\}$ OR $\{$ avonex $\}$

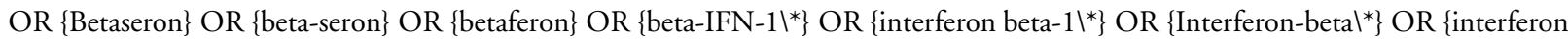
betal*\} OR \{recombinant interferon beta- $\left.11^{*}\right\}$

AND

\{azathioprine\} OR \{azathioprine\} OR \{immuran\} OR \{imuran\} OR \{imurel\}

\section{Interferon v Cyclophosphamide}

\{interferon $\left.1^{*}\right\}$ OR $\left\{\right.$ interferon beta\} OR $\left\{\right.$ beta-1 interferon\} OR \{beta 1 interferon\} OR \{interferon beta- $\left.11^{*}\right\}$ OR $\{$ rebif $\}$ OR $\{$ avonex $\}$

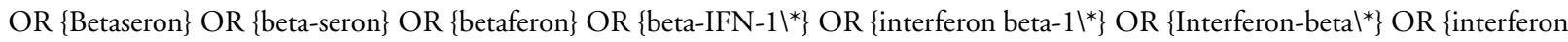
betal*\} OR \{recombinant interferon beta- $\left.11^{*}\right\}$

AND

\{cyclophosphamide\} OR \{phosphoramide mustard $\left.{ }^{*}\right\}$

\section{Interferon $\mathbf{v}$ Natalizumab}

\{interferon $\left.1^{*}\right\}$ OR \{interferon beta\} OR \{beta-1 interferon\} OR \{beta 1 interferon\} OR \{interferon beta- $\left.11^{*}\right\}$ OR $\{$ rebif $\}$ OR $\{$ avonex

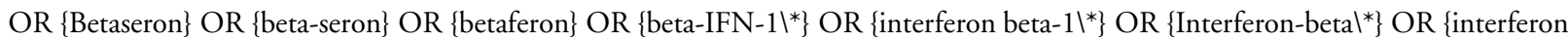
betal*\} OR \{recombinant interferon beta- $\left.11^{*}\right\}$

AND

\{antegren\} OR \{natalizumab\} OR \{tysabri\}

\section{Interferon v Mitoxantrone}

\{interferon $\left.1^{*}\right\}$ OR \{interferon beta\} OR \{beta-1 interferon\} OR \{beta 1 interferon\} OR \{interferon beta- $\left.11^{*}\right\}$ OR $\{$ rebif $\}$ OR $\{$ avonex

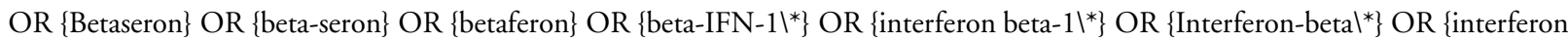
betal*\} OR \{recombinant interferon beta- $\left.11^{*}\right\}$

AND

\{novantrone\} OR \{novantron\} OR \{onkotrone\} OR \{pralifan\} OR \{mitozantrone\} OR \{mitoxantrone\}

\section{Interferon v Corticosteroids}

\{interferon $\left.1^{*}\right\}$ OR $\left\{\right.$ interferon beta\} OR $\left\{\right.$ beta-1 interferon\} OR \{beta 1 interferon\} OR \{interferon beta- $\left.11^{*}\right\}$ OR $\{$ rebif $\}$ OR $\{$ avonex $\}$ OR \{Betaseron\} OR \{beta-seron\} OR \{betaferon\} OR \{beta-IFN-1 $\left.\perp^{*}\right\}$ OR \{interferon beta- $\left.11^{*}\right\}$ OR $\{$ Interferon-betal*\} OR \{interferon betal*\} OR \{recombinant interferon beta- $\left.11^{*}\right\}$

AND

\{adrenal cortex hormones\} OR \{steroid $\left.{ }^{*}\right\}$ OR \{methylprednisolone\} OR \{prednisolone OR $\left\{\right.$ dexamethasone\} OR \{corticosteroid $\left.{ }^{*}\right\}$ OR \{acth\} OR \{prednisone\} OR \{Adrenocorticotropic Hormone\} 
Interferon v Immunoglobulins

\{interferon $\left.1^{*}\right\}$ OR \{interferon beta\} OR \{beta-1 interferon\} OR \{beta 1 interferon\} OR \{interferon beta- $\left.11^{*}\right\}$ OR \{rebif OR $\{$ avonex OR \{Betaseron\} OR \{beta-seron\} OR \{betaferon\} OR \{beta-IFN-1 $\left.1^{*}\right\}$ OR \{interferon beta- $\left.11^{*}\right\}$ OR \{Interferon-betal*\} OR \{interferon betal*\} OR \{recombinant interferon beta- $\left.11^{*}\right\}$

AND

\{immunoglobulin।*\} OR \{intravenous immunoglobulin।*\} OR \{iV immunoglobulin।*\}

Avonex v Rebif ${ }^{\circledR}$

\{beta-1a interferon\} OR \{beta 1a interferon\} OR \{interferon beta-1a\} OR \{rebif\}

AND

\{beta-1a interferon\} OR \{beta 1a interferon\} OR \{interferon beta-1a\} OR \{avonex\}

Avonex v Betaseron

\{beta-1a interferon\} OR \{beta 1a interferon\} OR \{interferon beta-1a\} OR \{avonex\}

AND

\{Betaseron\} OR \{beta-seron\} OR \{beta 1b interferon\} OR \{interferon beta1b $\}$ OR \{IFNb-1b\} OR \{IFNbeta-1b\} OR \{interferon beta$1 b\}$

\section{H I S T O R Y}

Protocol first published: Issue 1, 2011

Review first published: Issue 6, 2013

Date Event Description

17 January 2013 Amended Converted to Intervention review format. Title changed accordingly

\section{CONTRIBUTIONSOFAUTHORS}

Concept - GF, GS

Title registration - GF

Protocol draft - GF, GS

Protocol editing - GF, GS, CDP, DB

Title and abstract review - GF, GS

Search strategy - DB

Data abstraction - GF, LV

Data entry - GF, LV

Data analysis - GS, CDG

Drafting the review - GF, GS, CDG, LV

Editing and revising the review - GF, GS, CDG, LV, RDA, CDP

Immunomodulators and immunosuppressants for multiple sclerosis: a network meta-analysis (Review)

Copyright $\odot 2013$ The Cochrane Collaboration. Published by John Wiley \& Sons, Ltd. 


\section{DECLARATIONSOF INTEREST}

GF - none

GS - none

CDG - none

$\mathrm{DB}$ - none

LV - none

RDA - none

CDP - None

\section{SOURCES OF SUPPORT}

\section{Internal sources}

- Fondazione Istituto Neurologico Carlo Besta - Milan, Italy.

\section{External sources}

- Ministero della Salute - Direzione Generale della Ricerca Scientifica e Tecnologica, Project included in the Strategic Program "Therapy for MS, Italy.

DIFFERENCES BETWEEN PROTOCOL AND REVIEW

None 